\author{
GÖTTINGER ZENTRUM \\ FÜR BIODIVERSITÄTSFORSCHUNG UND ÖKOLOGIE \\ - Göttingen Centre for Biodiversity ANd Ecology -
}

\title{
Rainfall partitioning and soil water dynamics along a tree species diversity gradient in a deciduous old-growth forest in Central Germany
}

\author{
Dissertation zur Erlangung des Doktorgrades der \\ Mathematisch-Naturwissenschaftlichen Fakultäten der \\ Georg-August-Universität Göttingen \\ vorgelegt von \\ Diplom Landschaftsökologin und MSc Environmental Sciences \\ Inga Krämer \\ aus \\ Eckernförde
}

Rostock, 2009/2010 
Referent: Prof. Dr. Dirk Hölscher

Korreferent: Prof. Dr. Wolfgang Schmidt

Tag der mündlichen Prüfung: 30.11.2009 
There is no life without water. It is a treasure indispensable to all human activity.

(European Water Charter, Strasbourg 1968) 



\section{Contents}

1 Introduction 1

1.1 Forests: biodiversity and ecohydrology 3

1.2 The hydrological cycle in a forest $\quad 4$

$\begin{array}{ll}1.3 \text { Biodiversity research in forests } & 6\end{array}$

$\begin{array}{ll}1.4 \text { Umbrella project and study design } & 7\end{array}$

$\begin{array}{ll}1.5 \text { Study objectives and chapter outline } & 10\end{array}$

$\begin{array}{ll}1.6 \text { References } & 12\end{array}$

2 Rainfall partitioning along a tree diversity gradient in a deciduous old-growth forest in Central Germany 17

2.1 Abstract 19

2.2 Introduction 19

2.3 Methods 21

2.4 Results 29

2.5 Discussion 35

2.6 Conclusion 38

2.7 Acknowledgement 40

$\begin{array}{ll}2.8 \text { References } & 40\end{array}$

3 Soil water dynamics along a tree diversity gradient in a deciduous forest in Central Germany $\quad 47$

3.1 Abstract 49

3.2 Introduction 49

3.3 Methods 51

3.4 Results $\quad 57$

3.5 Discussion $\quad 62$

3.6 Conclusion $\quad 66$

$\begin{array}{ll}3.7 \text { Acknowledgement } & 67\end{array}$

$\begin{array}{ll}3.8 \text { References } & 67\end{array}$

4 Deposition and canopy exchange processes in central-German beech forests differing in tree species diversity 73

$\begin{array}{ll}4.1 \text { Abstract } & 75\end{array}$

4.2 Introduction $\quad 75$ 
$\begin{array}{ll}\text { 4.3 Material and Methods } & 78\end{array}$

4.4 Results $\quad 86$

$\begin{array}{ll}4.5 \text { Discussion } & 90\end{array}$

4.6 Conclusion 96

4.7 Acknowledgement 96

4.8 References $\quad 97$

5 Modeling stand water budgets of mixed temperate broad-leaved forest stands by considering variations in species-specific drought response 103

5.1 Abstract 105

5.2 Introduction 105

5.3 Material and Methods 107

5.4 Results and Discussion $\quad 114$

5.5 Conclusion 128

5.6 Acknowledgement 129

$\begin{array}{ll}5.7 \text { References } & 129\end{array}$

6 Discussion 137

6.1 Observed effects along the tree species diversity gradient: did biodiversity play a role? $\quad 139$

6.2 Relationships among the studied subjects 142

6.3 Relations to other studies in the umbrella project 143

6.4 Conclusion 148

$\begin{array}{ll}6.5 \text { References } & 148\end{array}$

Summary 153

$\begin{array}{ll}\text { Zusammenfassung } & 157\end{array}$

Acknowledgements 161 


\section{CHAPTER}

1

\section{Introduction}

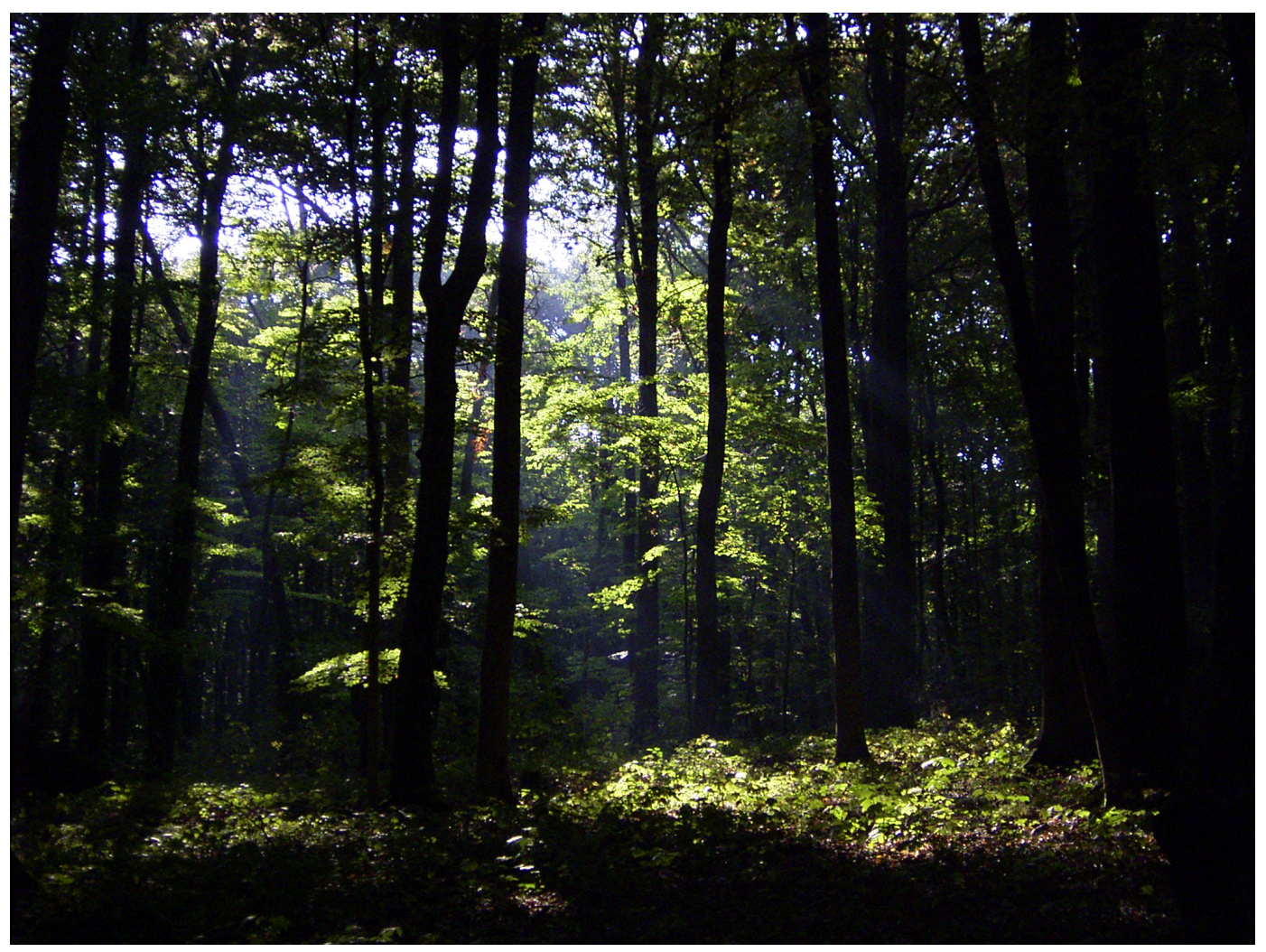




\subsection{FORESTS: BIODIVERSITY AND ECOHYDROLOGY}

Forests play an essential role in the global water, nutrient, and carbon cycle. From a hydrological point of view forests act as a water reserve, regulate water flow, and prevent soil erosion. Due to their large canopy surface area they also filter particles, such as nutrients, from the air (BMVEL, 2001). Owing to their multiple functions, forests provide services and goods as for example improved water quality and biodiversity (Anderson et al., 2000; FAO, 2008). Before humans started to impact the landscape considerably, forests formed the natural vegetation on a broad scale. Nowadays they are often important relicts of the former species assemblages and biodiversity and therefore subject to conservation efforts.

In Central Europe, beech forest communities, including other deciduous tree species, compose the potential natural vegetation in large areas. Beech (Fagus sylvatica L.) even tends to form monospecific stands over a wide range of site conditions (Ellenberg, 1996). However, during the past two centuries mainly coniferous species were used for reforestations (BMELV, 2004). The present forest cover in Germany accounts for $31 \%$ of the land area, whereof $62 \%$ is dominated by coniferous species and only $38 \%$ is broadleaved deciduous forest. Monospecific beech forests represent merely $2.4 \%$ of the total forest area while $4.9 \%$ of the total forest area consists of beech forest with admixture of other broadleaved deciduous species (BMELV, 2004). Recently, the establishment of mixed and deciduous forests has been promoted and increased in areas where site conditions are suitable (BMVEL, 2001; BMELV, 2004; Röhrig et al., 2006). Reasons for this change are supposedly higher stability against storms and diseases, and economical assurances. Additionally, this process supports the goals of the Convention on Biological Diversity (1993).

Biological diversity, also referred to as biodiversity, has been defined in many ways. The Convention on Biological Diversity (1993) declared biological diversity as 'the variability among living organisms from all sources including, inter alia, terrestrial, marine, and other aquatic ecosystems and the ecological complexes of which they are part: this includes diversity within species, between species, and of ecosystems'. Next to its intrinsic value, biological diversity has among others ecological, genetic, economic, scientific, and recreational values. However, biodiversity is significantly reduced by human activities and further biodiversity loss will diminish the positive effects on the provision of ecosystem services (Hooper et al., 2005; Balvanera et al., 2006).

Interdisciplinary research on the interrelationship between ecology and hydrology received recently renewed attention under the term 'ecohydrology'. Ecohydrology seeks to understand 
the interactions between the hydrological cycle and ecosystems (Porporato and RodriguezIturbe, 2002). This includes the influence of hydrological processes on ecosystem patterns, diversity, structure, and functions and how feedbacks from biological communities affect the hydrological cycle (Newman et al., 2006; Smettem, 2008). The importance of ecological and hydrological interrelationships is increasingly recognized as a central aspect in predicting and managing ecosystem dynamics (Zou et al., 2008). Major topics of ecohydrology are for example the role of the vegetation in rainfall interception processes (van Dijk, 2004), soil water and plant relations (Rodriguez-Iturbe, 2000; Porporato and Rodriguez-Iturbe, 2002; Dolman, 2003; Rodriguez-Iturbe and Porporato 2004; van Dijk, 2004), and the interrelationship between the hydrological cycle and other biogeochemical cycles such as the central role of water as a transport mechanism for nutrients (Dolman, 2003).

\subsection{THE HYDROLOGICAL CYCLE IN A FOREST}

The water budget of a forest includes the rates of input and output as well as the storage changes of water in the system. The main components are shown in Figure 1.1. Some rainwater is temporarily stored (intercepted) on surfaces such as leaves, branches, and stems of trees and on the herb- and litter layer and evaporates back into the atmosphere. Rainfall passes the canopy directly through gaps or indirectly after contact with the canopy as throughfall and stemflow. The water which finally reaches the soil surface can evaporate from the soil surface, occur as surface runoff, or infiltrate into the soil. Infiltrated water can be stored in the soil, taken up by the vegetation for transpiration, or may leave the rooted soil volume as drainage water or as slope parallel interflow.

Closely coupled to the forest hydrological cycle are the deposition and transportation of ions such as nitrogen and phosphorus by the rainwater. The deposition of ions in forests depends among others on the leaf area, the physical and chemical properties of the leaf surface, and the structural properties of the canopy (Erisman and Draaijers, 2003). The canopy can act as a source or a sink for deposited ions due to canopy exchange processes. Next to litterfall, both throughfall and stemflow transport ions to the forest floor. 


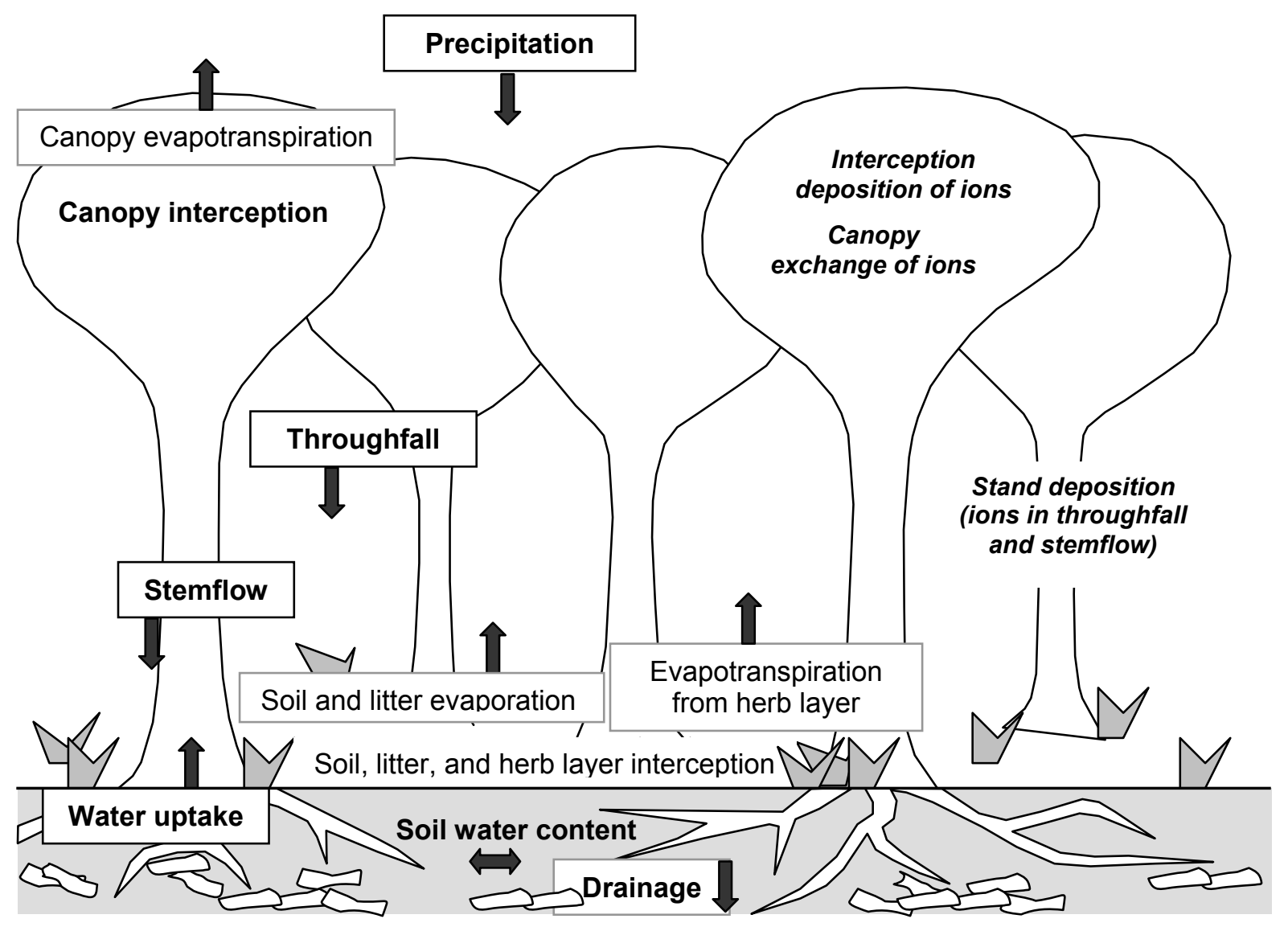

Figure 1.1 Main components of the hydrological cycle (in standard) and coupled ion transfer and processes (in italics) in a forest. Aspects which are in the focus of this study, including interdisciplinary cooperation with other projects, are highlighted in bold.

Depending on the spatial and temporal scale and the required complexity, several methods to measure components of the hydrological cycle in a forest are available. Widely used for determining evapotranspiration and its components are for example the establishment of soil or catchment water budgets as well as sap flow and eddy covariance measurements (Wilson et al., 2001). Particular investigations include stemflow and throughfall measurements, and investigations of evaporation and transpiration processes as well as soil water dynamics.

Since meteorological conditions vary considerably inter-annually, it is necessary to observe components of the forest hydrological cycle over the course of several years if a reliable quantification shall be achieved. Several components of the hydrological cycle which are difficult to assess are often calculated using mathematical modelling approaches.

Hydrological aspects such as throughfall, stemflow, and interception were investigated extensively in beech forests (for an overview see Peck, 2004) and compared between 
deciduous (beech) and coniferous forests (Norway spruce (Picea abies (L.) Karst.)) (e.g. Weihe, 1984, 1985; Bücking and Krebs, 1986). Also soil water dynamics were investigated as well in beech forests (e.g. Gerke, 1987) as for comparison between deciduous (beech) and coniferous forests (spruce) (e.g. Benecke, 1984; Schume et al., 2004). Information on hydrological aspects of tree species such as small-leaved lime (Tilia cordata Mill.), largeleaved lime (Tilia platyphyllos Scop.), ash (Fraxinus excelsior L.), sycamore (Acer pseudoplatanus L.), and hornbeam (Carpinus betulus L.) is relatively scarce. Single hydrological processes such as rainfall interception as well as entire water cycles were simulated successfully for beech (Herbst et al., 1999), beech and spruce (Armbruster et al., 2004; Christiansen et al., 2006), and mixed stands (Bouten et al., 1992; Armbruster et al., 2004; Rötzer et al., 2005; Herbst et al., 2008). Until now, however, no study has compared monospecific beech to mixed deciduous forest stands regarding possible tree species diversity effects on forest hydrology.

\subsection{BIODIVERSITY RESEARCH IN FORESTS}

Most studies on biodiversity effects have been carried out in grasslands, because these ecosystems are easy to control and to manipulate and can be established much faster than forests. In contrast, forest diversity and its effects on biogeochemical cycles have gained research attention only recently (Scherer-Lorenzen et al., 2005; Leuschner et al., 2009). Within the last 20 years, seven long-term experiments aiming to investigate the effects of tree species diversity on ecosystem processes were set up worldwide: two in boreal (Finland), two in temperate (Germany), and three in tropical forests (Panama and Borneo; Scherer-Lorenzen, 2005). These forest stands are still relatively young and it might be difficult to relate the findings to potential responses of mature forest systems. Further problems of those forest diversity experiments can be edge effects and the artificial and even-aged structure. Therefore, it is important to combine experimental and observational studies in mature forest stands of contrasting tree species diversity (Leuschner et al., 2009).

Possible biodiversity effects in forests range from structural aspects such as canopy organisation and root distribution to differences in resource use. Species rich communities may exploit the available space both in two (covered area) and three (canopy volume) dimensions more effectively; they also may use the available space more efficiently through increased canopy or root density and biomass (Spehn et al., 2005). Neighbourhood effects in 
canopy space occupation were revealed for ash, hornbeam, and lime in the same forest in which the present study took place (Frech et al., 2003). According to that study, crown overlap was larger in inter- than in intraspecific associations. Competing species may also occupy different soil niches as for example shown for beech in mixture with other species (Büttner and Leuschner, 1994; Rothe and Binkley, 2001; Schmid, 2002; Schmid and Kazda, 2002).

Water is an exhaustible resource and therefore subject to competition. Differentiation in hydrological niches can be a possible biodiversity effect and by tapping an otherwise unused source a species could alter resource supply (Chapin III et al., 1997). Studies on the influence of biodiversity on soil water dynamics were carried out mostly in grasslands (e.g. Caldeira et al., 2001; van Peer et al., 2004; de Boeck et al., 2006; Stocker et al., 1999; Spehn et al., 2000; Kreutziger, 2006) while little attention has been given to forests (Meinzer et al., 1999; Gebauer, 2010). Investigations in grasslands yielded contrasting results. Some studies reported biodiversity effects on water dynamics (e.g. Caldeira et al., 2001; van Peer et al., 2004; de Boeck et al., 2006) while others did not observe any effect (e.g. Stocker et al., 1999; Spehn et al., 2000). This lack of diversity effect was for example attributed to opposing effects of diversity on soil evaporation (decrease due to increased plant cover) and plant transpiration (increase due to increased productivity; Spehn et al., 2000).

Effects of biodiversity can be separated into two major categories of explanation: a complementarity effect and a selection effect (Loreau and Hector, 2001). The complementarity effect arises from niche differentiation and/or facilitation between species, processes which increase the performance of multi-species communities compared to that expected from species grown in monoculture. Niche differentiation is related to resource partitioning; facilitation refers to positive (facilitative) species interactions. Distinguishing the effects of niche differentiation and facilitation may often be difficult in practice (Loreau and Hector, 2001). The selection effect results from the greater probability in diverse communities to include a species or combination of species, which has particular traits with a dominant influence on ecosystem processes.

\subsection{UMBRELLA PROJECT AND STUDY DESIGN}

The present study took place in the Hainich National Park in Thuringia, Central Germany. The Hainich represents the largest coherent broad-leaved deciduous forest system in Germany 
and comprises a large variety of tree species. For the last 40 years, only single stems have been extracted from the investigated forest stands and the sites are covered with deciduous forest since at least 200 years (Schmidt et al., 2009).

The study was carried out within the framework of the interdisciplinary Research Training Group (DFG-Graduiertenkolleg 1086) on 'The role of biodiversity for biogeochemical cycles and biotic interactions in temperate deciduous forests'. In forest stands of different species assemblages, several subprojects investigate aspects such as productivity, nutrient and water turnover, and biotic interactions among key organism groups (for a more detailed list see Leuschner et al., 2009).

During the first project phase (starting in 2005), twelve study plots with different tree species combinations were selected. These plots represented a diversity gradient from monospecific beech stands to stands composed of up to 11 tree species (Figure 1.2). Present species were European beech (Fagus sylvatica L.), lime (Tilia cordata Mill. and T. platyphyllos Scop.), ash (Fraxinus excelsior L.), hornbeam (Carpinus betulus L.), and sycamore (Acer pseudoplatanus L.) and with minor contribution Acer platanoides L., A. campestre L., Prunus avium L., Quercus robur L., Q. petraea (Matt.) Liebl., Sorbus torminalis L., and Ulmus glabra Huds. Shannon diversity index (H', Shannon and Weaver, 1949) for the tree layer, based on the number of stems, ranged from 0 to 1.7. Plot names follow the classification given by the research group and define a diversity level (DL1 to DL3), each level being replicated four times (a-d). Stands containing at least $80 \%$ of a single species are termed monospecific stands in this study; this is valid for the four DL1 stands.

In each study plot, three transects (with two subplots) were chosen randomly where the majority of measurements took place (Figure 1.3). For this doctoral thesis, measurements of throughfall (quantitative and qualitative) and soil water dynamics were obtained along these transects (Figure 4a-c; for details see Chapter 2, 3, and 4). Further measurements as for example of fine root distribution, litter layer thickness, soil temperature, and collection of leaves for leaf area index (LAI) determination were carried out by other project members along the transects or inside the subplots. Additionally, some measurements were done adjacent to the study plots (e.g. stemflow) or on trees distributed over the whole study plots (e.g. productivity, sap flow). 


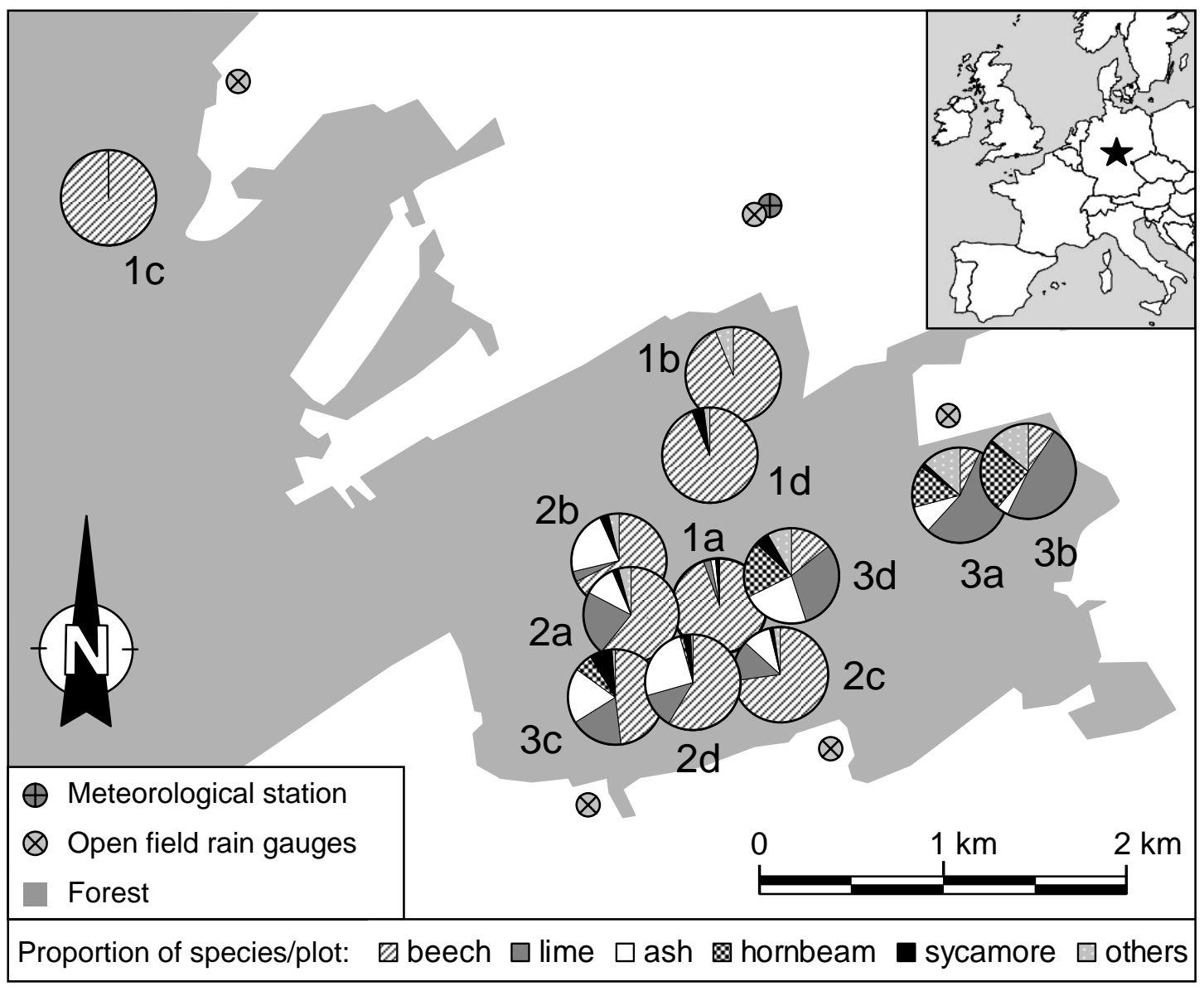

Figure 1.2 South-eastern part of the Hainich National Park: the twelve study plots and their species assemblages; pie charts represent locations of the study plots but not plot size (for further description see Chapter 2).

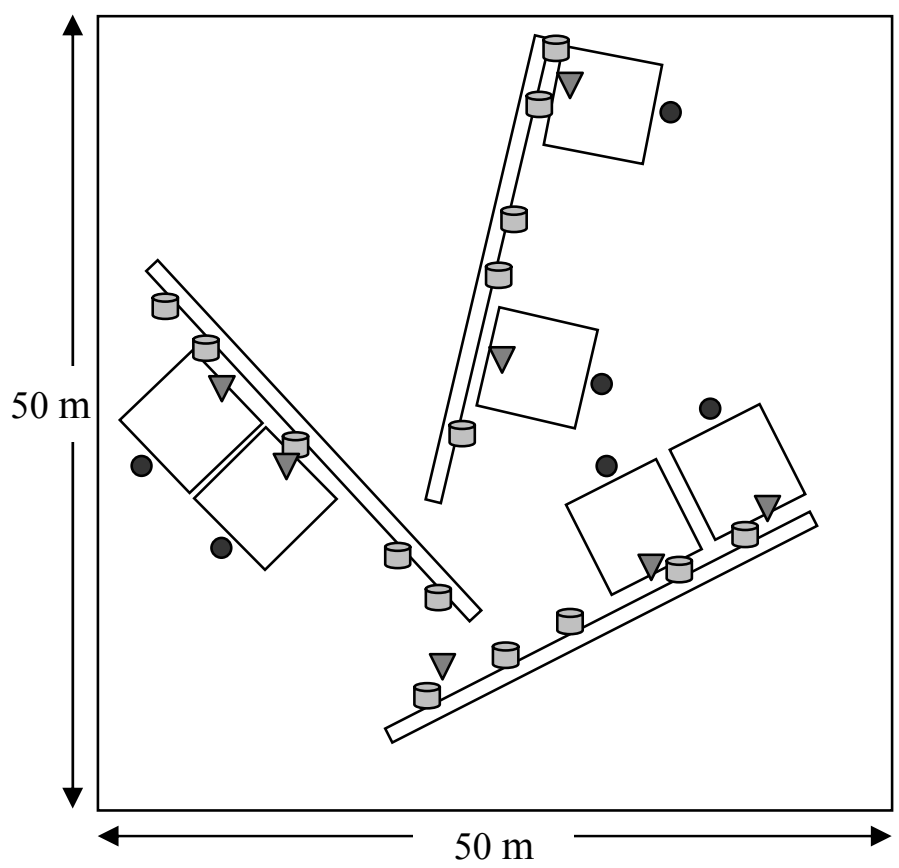

Rainfall collectors

- FDR access tubes

$\nabla \quad$ Tensiometer

Figure 1.3 Example of the study plot design with measurement locations of this study along the randomly distributed transects and subplots. 


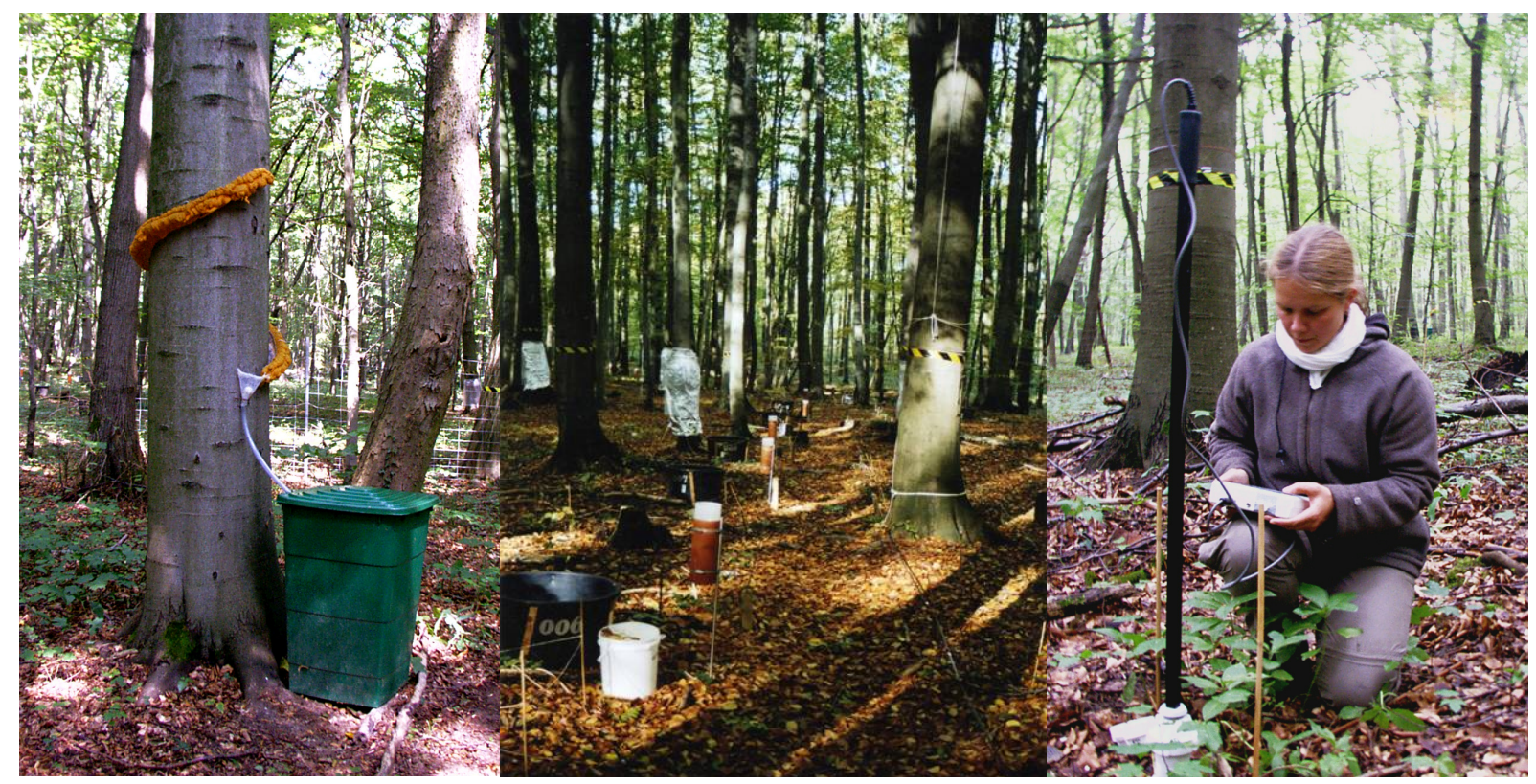

Figure 1.4 Measurements of stemflow, throughfall, and soil water dynamics (FDR technique) in the present study.

\subsection{STUDY OBJECTIVES AND CHAPTER OUTLINE}

The main objectives of this doctoral thesis were to investigate several ecohydrological aspects along a tree species diversity gradient of monospecific beech to mixed deciduous forest stands. On twelve study plots along this gradient, rainfall partitioning components, i.e. throughfall, stemflow and interception, were measured and several stand characteristics were evaluated that contributed to the variability of these components. Additionally, throughfall heterogeneity within the study plots was compared among the different study plots (Chapter 2). Soil water dynamics were investigated along the tree species diversity gradient with two different methods (FDR-sensor and tensiometer), and within plot heterogeneity of volumetric soil water content was compared among the twelve study plots (Chapter 3). In cooperation with other subprojects of the umbrella project in the Hainich, the ion composition of throughfall and stemflow was analysed on nine study plots and interception deposition of ions, canopy exchange processes, and possible influencing stand characteristics were evaluated (Chapter 4). Rainfall partitioning components as well as soil water data were used for modelling the water dynamics of three study plots including one from each diversity level (DL1, DL2, DL3; Chapter 5). 
Investigations of the hydrological cycle in near natural forests like in the Hainich National Park can contribute to a more complete knowledge of these ecosystems. Furthermore, the results can provide information for the management of deciduous forests in Central Europe to meet the demands of the society related to water resources as well as to ensure forest vitality under changing climatic conditions.

The following publications are integrated in this thesis:

Krämer I, Hölscher D. 2009. Rainfall partitioning along a tree diversity gradient in a deciduous old-growth forest in Central Germany. Ecohydrology 2: 102-114.

Krämer I, Hölscher D. 2010. Soil water dynamics along a tree diversity gradient in a deciduous forest in Central Germany. Ecohydrology 3: 262-271.

Talkner U, Krämer I, Hölscher D, Beese FO. In press. Deposition and canopy exchange processes in central-German beech forests differing in tree species diversity. Plant and Soil, DOI: $10.1007 / \mathrm{s} 11104-010-0491-2$.

Bittner S, Talkner U, Krämer I, Beese FO, Hölscher D, Priesack E. 2010. Modeling stand water budgets of mixed temperate broad-leaved forest stands by considering variations in species-specific drought response. Agricultural and Forest Meteorology 150: 1347-1357.

I. Krämer is the first author of the first two manuscripts (Chapter 2 and 3), where she carried out most of the measurements, analysed the data and evaluated them statistically, produced all tables and figures and prepared the manuscript.

For the third study (Chapter 4), I. Krämer provided the water samples of gross precipitation, throughfall and stemflow. Furthermore, she was involved in data analyses and preparation of the manuscript, which included literature research, discussions on statistical analyses and interpretation of results, and several revisions of the manuscript.

For the fourth manuscript (Chapter 5), I. Krämer contributed data such as throughfall of single rainfall events, rainfall partitioning components (gross precipitation and throughfall), and volumetric soil water content over the entire study period for the model parameterisation and validation. She was further involved in data analyses and preparation of the manuscript, which included literature research, discussions on the modelling process and interpretation of results, and several revisions of the manuscript. 


\subsection{REFERENCES}

Anderson FO, Feger K-H, Hüttl RF, Kräuchi N, Mattson L, Sallnäs O, Sjöberg K. 2000. Forest ecosystem research - priorities for Europe. Forest Ecology and Management 132: 111-119.

Armbruster M, Seegert J, Feger K-H. 2004. Effects of changes in tree species composition on water flow dynamics - Model applications and their limitations. Plant and Soil 264: 1324.

Balvanera P, Pfisterer AB, Buchmann N, He J-S, Nakashizuka T, Raffaelli D, Schmid B. 2006. Quantifying the evidence for biodiversity effects on ecosystem functioning and services. Ecology Letters 9: 1146-1156.

Benecke P. 1984. Der Wasserumsatz eines Buchen- und eines Fichtenwaldökosystems im Hochsolling. Schriften aus der Forstlichen Fakultät der Universität Göttingen und der Niedersächsischen Forstlichen Versuchsanstalt 77. Sauerländer's Verlag Frankfurt am Main.

BMELV (Bundesministerium für Ernährung, Landwirtschaft und Verbraucherschutz). 2004.

2. Bundeswaldinventur. www.bundeswaldinventur.de.

BMVEL (Bundesministerium für Verbraucherschutz, Ernährung und Landwirtschaft) (ed.). 2001. Gesamtwaldbericht der Bundesregierung. BMVEL: Bonn.

Bouten W, Schaap MG, Bakker DJ, Verstraten JM. 1992. Modelling soil water dynamics in a forested ecosystem. I: A site specific evaluation. Hydrological Processes 6: 435-444.

Bücking W, Krebs A. 1986. Interzeption und Bestandesniederschläge von Buche und Fichte im Schönbuch. In: Einsele G (ed): Das landschaftsökologische Forschungsprojekt Naturpark Schönbuch. VCH: Weinheim.

Büttner V, Leuschner C. 1994. Spatial and temporal patterns of fine root abundance in a mixed oak-beech forest. Forest Ecology and Management 70: 11-21.

Caldeira, MC, Ryel RJ, Lawton JH, Pereira JS. 2001. Mechanisms of positive biodiversityproduction relationships: insights provided by $\delta^{13} \mathrm{C}$ analysis in experimental Mediterranean grassland plots. Ecology Letters 4: 439-443.

Convention on Biological Diversity. 1993. www.cbd.int

Chapin III FS, Walker BH, Hobbs RJ, Hooper DU, Lawton JH, Sala OE, Tilman D. 1997. Biotic control over the functioning of ecosystems. Science 277: 500-504.

Christiansen JR, Elberling B, Jansson P-E. 2006. Modelling water balance and nitrate leaching in temperate Norway spruce and beech forests located on the same soil type with the CoupModel. Forest Ecology and Management 237: 545-556. 
De Boeck HJ, Lemmens CMHM, Bossuyt H, Malchair S, Carnol M, Merckx R, Nijs I, Ceulemans R. 2006. How do climate warming and plant species richness affect water use in experimental grasslands? Plant Soil 288: 249-261.

Dolman H. 2003. Ecohydrology: patterns and variability in vegetation soil atmosphere interaction. Position paper for the Royal Netherlands Academy of Arts and Sciences working group on hydrology, 6/2/03.

Ellenberg H. 1996. Vegetation Mitteleuropas mit den Alpen in ökologischer, dynamischer und historischer Sicht. Ulmer: Stuttgart.

Erisman JW, Draaijers G. 2003. Deposition to forests in Europe: most important factors influencing dry deposition and models used for generalization. Environmental Pollution 124: $379-388$.

FAO (Food and Agricultural Organization of the United Nations). 2008. Forests and water. A thematic study prepared in the framework of the global forest resources assessment 2005. FAO Forestry Paper 155. FAO: Rome.

Frech A, Leuschner C, Hagemeier M, Hölscher D. 2003. Nachbarschaftsbezogene Analyse der Kronenraumbesetzung von Esche, Hainbuche und Winterlinde in einem artenreichen Laubmischwald (Nationalpark Hainich, Thüringen). (Neighbor-dependent canopy dimensions of ash, hornbeam, and lime in a species-rich mixed forest (Hainich Nationalpark, Thuringia)). Forstwissenschaftliches Centralblatt 122: 22-35.

Gebauer T. 2010. Water turnover in species-rich and species-poor deciduous forests: xylem sap flow and canopy transpiration. Dissertation. Göttingen Centre for Biodiversity and Ecology. Biodiversity and Ecology Series B Vol. 4. University of Göttingen, Göttingen.

Gerke H. 1987. Untersuchungen zum Wasserhaushalt eines Kalkbuchenwald-Ökosystems und zur Wasserbewegung in flachgründigen Böden und im durchwurzelten Kalkgestein als Grundlage zur Modellentwicklung. Berichte des Forschungszentrums Waldökosysteme/ Waldsterben A 27.

Herbst M, Eschenbach C, Kappen L. 1999. Water use in neighbouring stands of beech (Fagus sylvatica L.) and black alder (Alnus glutinosa (L.) Gaertn.). Annals of Forest Science 56: $107-120$.

Herbst M, Rosier PTW, McNeil DD, Harding RJ, Gowing DJ. 2008. Seasonal variability of interception evaporation from the canopy of a mixed deciduous forest. Agricultural and Forest Meteorology 148: 1655-1667.

Hooper DU, Chapin III FS, Ewel JJ, Hector A, Inchausti P, Lavorel S, Lawton JH, Lodge DM, Loreau M, Naeem S, Schmid B, Setälä H, Symstad AJ, Vandermeer J, Wardle DA. 
2005. Effects of biodiversity on ecosystem functioning: a consensus of current knowledge. Ecological Monographs 75: 3-35.

Kreutziger Y. 2006. Rückkopplungseffekte verschieden diverser Grünlandökosysteme auf die Komponenten des Bodenwasserhaushalts an einem Auestandort der Saale. Ergebnisse des Jenaer Biodiversitätsexperiments. PhD thesis. University of Jena. http://deposit.ddb.de/ cgi-bin/dokserv?idn=982774559\&dok_var=d1\&dok_ext=pdf\& filename= 982774559.pdf. Leuschner C, Jungkunst HF, Fleck S. 2009. Functional role of forest diversity: Pros and cons of synthetic stands and across-site comparisons in established forests. Basic and Applied Ecology 10: 1-9.

Loreau M, Hector A. 2001. Partitioning selection and complementarity in biodiversity experiments. Nature 412: 72-76.

Meinzer FC, Andrade JL, Goldstein G, Holbrook NM, Cavelier J, Wright SJ. 1999. Partitioning of soil water among canopy trees in a seasonally dry tropical forest. Oecologia 121: 293-301.

Newman BD, Wilcox BP, Archer SR, Breshears DD, Dahm CN, Duffy CJ, McDowell NG, Phillips FM, Scanlon BR, Vivoni ER. 2006. Ecohydrology of water-limited environments: a scientific vision. Water Resources Research 42: W06302.

Peck AK. 2004. Hydrometeorologische und mikroklimatische Kennzeichen von Buchenwäldern. $\mathrm{PhD}$ thesis. Berichte des Meteorologischen Institutes der Universität Freiburg 10, University of Freiburg. www.mif.uni-freiburg.de/berichte/Bericht10.pdf.

Porporato A, Rodriguez-Iturbe I. 2002. Ecohydrology - a challenging multidisciplinary research perspective. Hydrological Sciences-Journal 47: 811-821.

Rodriguez-Iturbe I. 2000. Ecohydrology: a hydrologic perspective of climate-soil-vegetation dynamics. Water Resources Research 36: 3-9.

Rodriguez-Iturbe I., Porporato A. 2004. Ecohydrology of water-controlled ecosystems: soil moisture and plant dynamics. Cambridge University Press, Cambridge.

Röhrig E, Bartsch N, von Lüpke B. 2006. Waldbau auf ökologischer Grundlage. Ulmer: Stuttgart.

Rothe A, Binkley D. 2001.Nutritional interactions in mixed species forests: a synthesis. Canadian Journal of Forest Research 31: 1855-1870.

Rötzer T, Grote R, Pretzsch H. 2005. Effects of environmental changes on the vitality of forest stands. European Journal of Forest Research 124: 349-362. 
Scherer-Lorenzen M, Potvin C, Koricheva J, Schmid B, Hector A, Bornik Z, Reynolds G, Schulze E-D. 2005. The design of experimental tree plantations for functional biodiversity research. In: Scherer-Lorenzen M, Körner C, Schulze E-D (eds). Forest diversity and function. Temperate and boreal Systems. Ecological Studies 176, Springer: Berlin.

Schmid I. 2002. The influence of soil type and interspecific competition on the fine root system of Norway spruce and European beech. Basic and Applied Ecology 3: 339-346.

Schmid I, Kazda M. 2002. Root distribution of Norway spruce in monospecific and mixed stands on different soils. Forest Ecology and Management 159: 37-47.

Schmidt I, Leuschner C, Mölder A, Schmidt W. 2009. Structure and composition of the seed bank in monospecific and tree species-rich temperate broad-leaved forests. Forest Ecology and Management 257: 695-702.

Schume H, Jost G, Hager H. 2004. Soil water depletion and recharge patterns in mixed and pure forest stands of European beech and Norway spruce. Journal of Hydrology 289: 258274.

Shannon CE, Weaver W. 1949. The mathematical theory of communication. University of Illinois Press: Urbana.

Smettem KRJ. 2008. Welcome address for the new 'Ecohydrology' Journal. Ecohydrology 1: $1-2$.

Spehn EM, Hector A, Joshi J, Scherer-Lorenzen M, Schmid B, Bazeley-White E, Beierkuhnlein C, Caldeira MC, Diemer M, Dimitrakopoulos PG, Finn JA, Freitas H, Giller GS, Good J, Harris R, Högberg P, Huss-Danell K, Jumpponen A, Koricheva J, Leadley PW, Loreau M, Minns A, Mulder CPH, O’Donovan G, Otway SJ, Palmborg C, Pereira JS, Pfisterer AB, Prinz A, Read DJ, Schulze E-D, Siamantziouras ASD, Terry AC, Troumbis AY, Woodward FI, Yachi S, Lawton JH. 2005. Ecosystem effects of biodiversity manipulations in European grasslands. Ecological Monographs 75: 37-63.

Stocker R, Körner C, Schmid B, Niklaus PA, Leadley PW. 1999. A field study of the effects of elevated $\mathrm{CO}_{2}$ and plant species diversity on ecosystem-level gas exchange in a planted calcareous grassland. Global Change Biology 5: 95-105.

van Peer L, Nijs I, Reheul D, de Cauwer B. 2004. Species richness and susceptibility to heat and drought extremes in synthesized grassland ecosystems: compositional vs physiological effects. Functional Ecology 18: 769-778.

van Dijk A. 2004. Ecohydrology: it's all in the game? Hydrological Processes 18: 3683-3686. 
Weihe J. 1984. Benetzung und Interzeption von Buchen- und Fichtenbeständen in NW. IV. Die Verteilung des Regens unter Fichtenkronen. Allgemeine Forst- und Jagdzeitung 155: $241-252$.

Weihe J. 1985. Benetzung und Interzeption von Buchen- und Fichtenbeständen in NW. V. Die Verteilung des Regens unter Buchenkronen. Allgemeine Forst- und Jagdzeitung 156: $81-89$.

Wilson KB, Hanson PJ, Mulholland PJ, Baldocchi DD, Wullschleger SD. 2001. A comparison of methods for determining forest evapotranspiration and its components: sapflow, soil water budget, eddy covariance and catchment water balance. Agricultural and Forest Meteorology 106: 153-168.

Zou CB, Breshears DD, Newman BD, Wilcox BP, Gard MO, Rich PM. 2008. Soil water dynamics under low-versus high-ponderosa pine tree density: ecohydrological functioning and restoration implications. Ecohydrology 1: 309-315. 


\section{CHAPTER}

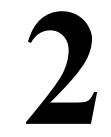

\section{Rainfall partitioning along a tree diversity gradient in a deciduous old-growth forest in Central Germany}

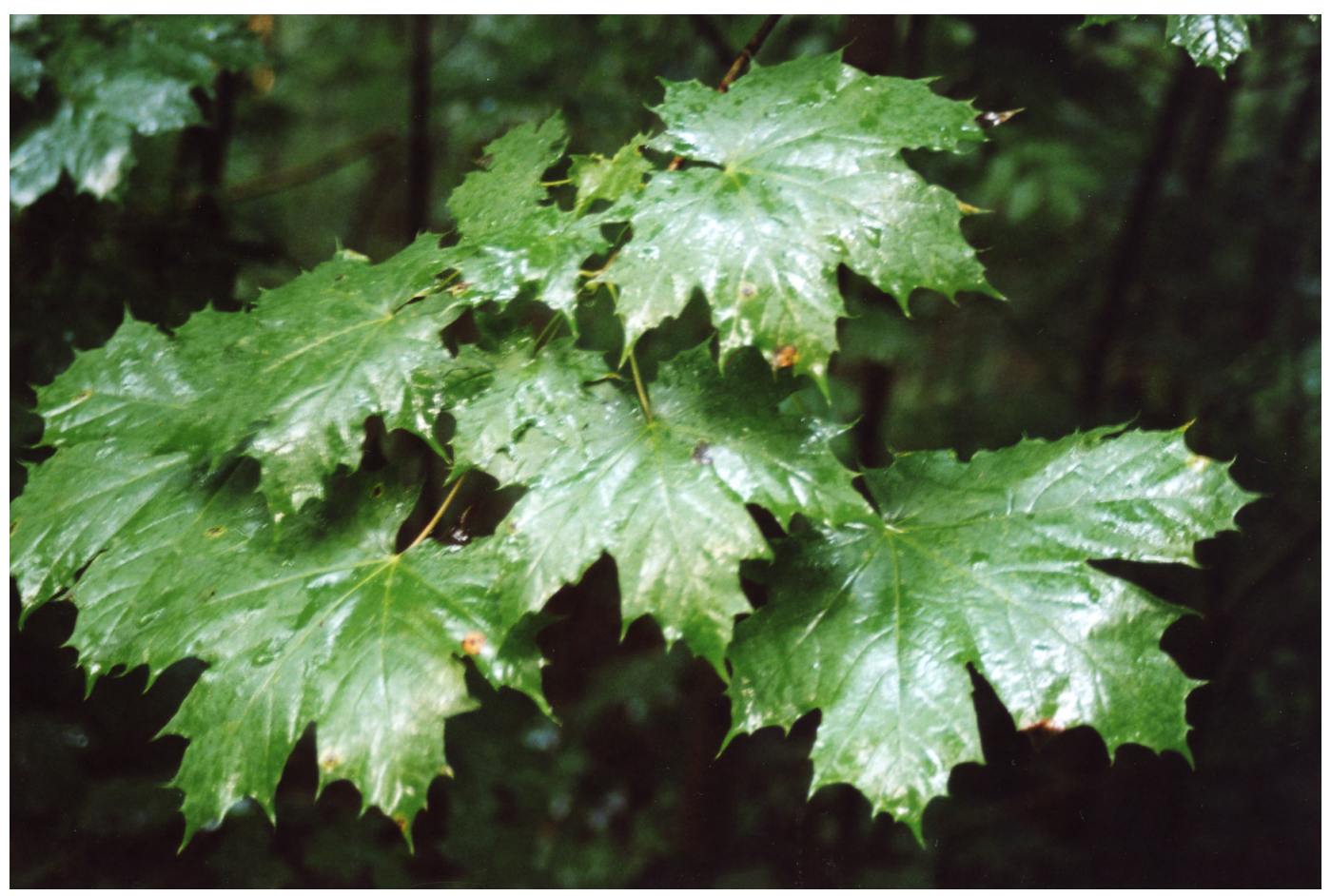




\subsection{ABSTRACT}

This study investigated whether rainfall partitioning into throughfall, stemflow, and interception changes along a tree species diversity gradient. The twelve study plots in oldgrowth forest stands in the Hainich National Park, Germany, were composed of up to eleven tree species. Fagus sylvatica (beech) formed the monospecific plots. Mixed forest plots consisted of a variable admixture of other broad-leaved deciduous species such as Tilia spec., Fraxinus excelsior, Carpinus betulus, and Acer pseudoplatanus. Rainfall partitioning was influenced by several stand characteristics. Tree species diversity expressed as Shannon index was the variable that explained throughfall for different seasons most frequently. For example, in high-rainfall summer 2007, median throughfall per stand was between 66 and $77 \%$ of gross precipitation, whereas stemflow played a minor role (2-6\% per stand). Throughfall correlated positively with Shannon index $\left(r_{s}=0.74, p=0.008\right)$, stemflow negatively $\left(r_{s}=-0.87, p<0.001\right)$, and interception showed no correlation along this beech to mixed forest gradient. These relationships were similar in summer 2005 and autumn 2006, but no or weak changes of throughfall with tree diversity were observed during other study periods. Multiple linear regressions supported the assumption that combinations of several characteristics are important. Shannon index in combination with mean dbh explained much of the variability observed in throughfall among stands in two seasons (up to $\mathrm{R}_{\text {adj }}^{2}=0.63$, $\mathrm{p}<0.01$ ). Influential stand characteristics varied between seasons and years due to different rainfall conditions. Spatial variability of throughfall within a stand did not change consistently with any stand characteristic.

\subsection{INTRODUCTION}

Rainfall partitioning in forests, divided into throughfall, stemflow, and interception, is influenced by stand and in particular canopy structural characteristics. These characteristics comprise e.g. leaf inclination, nature of the bark, branch angle, canopy roughness, and leaf area index (LAI) (Crockford and Richardson, 2000). Rainfall and other meteorological conditions also play an important role (Crockford and Richardson, 2000; Levia and Frost, 2006). Differences in interception, throughfall heterogeneity, and split-up ratios of rainfall into throughfall (diffuse input) and stemflow (point input) may affect physical, chemical, and biological processes of forest ecosystems. Besides direct effects on soil moisture and soil 
solute chemistry, also litter decay, understorey vegetation, distribution of fine roots etc. could be influenced (e.g. Anderson et al., 1969; Leuschner et al., 2004; Lensing and Wise, 2007).

In Central Europe, beech forest communities prevail at a broad scale the potential natural vegetation and beech (Fagus sylvatica) even tends to form monospecific stands over a wide range of site conditions (Ellenberg, 1996). Nonetheless, recent forest management schemes favour mixed stands (Bartelink and Olsthoorn, 1999; BMVEL, 2001; Röhrig et al., 2006), because they are assumed to reduce risk of pest invasion and diseases and may be better adapted to climate change and changing market conditions. On nutrient rich soils in Germany, target stands comprise a mixture of beech with other broad-leaved deciduous tree species such as lime (Tilia cordata and T. platyphyllos), ash (Fraxinus excelsior), hornbeam (Carpinus betulus), and sycamore (Acer pseudoplatanus).

In a comprehensive review (Peck 2004), throughfall percentages in European beech forests were found to vary between 60 and $95 \%$ of gross precipitation in long term studies (gross precipitation will serve as reference for rainfall partitioning from hereon). Beech is known for high stemflow percentages, which were on average 12\% (Mitscherlich, 1981; Peck, 2004). Overall interception (gross precipitation minus throughfall and stemflow) of beech was on average 20\% (Peck, 2004), 22\% (Augusto et al., 2002), and 28\% (Forgeard et al., 1980). Although differences between coniferous and broad-leaved trees are well studied (e.g. Weihe, 1984, 1985), broad-leaved tree species of Central European forests others than beech have been less investigated with respect to rainfall partitioning (Peck and Mayer, 1996). This is most likely because monospecific stands of these species are not very common. Especially studies of different tree species or forest types carried out under similar meteorological conditions are rare. One study on differences in rainfall partitioning analyzing five deciduous species was conducted in Southern Sweden (Nordén, 1991). According to this author, throughfall was lowest for beech, followed by Norway maple (A. platanoides), small-leaved lime (Tilia cordata), hornbeam, and common oak (Quercus robur) in ascending order. In an uneven-aged mixed forest in Denmark, ash had only half as much stemflow as beech (Dalsgaard, 2007). Mean stemflow of hornbeam was 13\% (Mitscherlich, 1981), which is quite similar to that of beech. According to reviews, precipitation interception by hornbeam averages 27\% (Augusto et al., 2002) and 22\% (Mitscherlich, 1981), which is also close to values shown for beech dominated forests.

Among tree species, structural traits differ, e.g. beech, lime, ash, hornbeam, and sycamore are known for their different crown structure (e.g. Roloff, 1989; Körner, 2005) and phenology. 
Different timing of leafing and leaf shedding could lead to differences in interception during spring and autumn. For example, higher throughfall could be caused by ash, since ash is known to get into leaves relatively late in spring, to develop comparatively low leaf area, and to move very easily with wind.

Additionally, mixed stands may reveal characteristics that are more than the sum of tree species traits in pure stands. If species in a stand have different ecological characteristics, as for example different shade tolerances, they may create different layers and occupy different niches in the canopy space (Kelty, 1992; Menalled et al., 1998; Pretzsch, 2005). Neighbourhood effects in canopy space occupation were revealed for ash, hornbeam, and lime in the same forest in which the present study took place (Frech et al., 2003). As a result, crown overlap was larger if neighbouring trees belonged to another species rather than to the same. This leads to the assumption that mixed forest stands may have larger crown overlap and thus probably higher leaf area index than pure stands. Additionally, mixed forests may develop less uniform canopies than monospecific beech forests. This could result in a more heterogeneous spatial distribution of throughfall at the forest floor (Levia and Frost, 2006).

However, conclusions on the influences of stand structural characteristics and tree species diversity on rainfall partitioning are so far difficult to draw as many available studies were done under different climatic conditions and also often lack sufficient replicate stands. The present study was conducted simultaneously in twelve adjacent old-growth forest stands. The deciduous broad-leaved forest stands were located under comparable site conditions, and tree species composition ranged from pure beech stands to stands composed of up to eleven species. The questions we wanted to answer were: How does rainfall partitioning change along a tree diversity gradient from monospecific beech stands to mixed forest stands, and does the spatial heterogeneity in throughfall increase along this gradient?

\subsection{METHODS}

\section{Study area}

The present study was conducted in the Hainich National Park in Thuringia, Central Germany. The National Park was founded in 1997 and mainly consists of species-rich deciduous forest located at the southern edge of the Hainich, a low mountain range. Even before the area was declared National Park, only minimal forest management took place for 
decades due to military use. However, differences in tree species composition may result from previous forest management in the form of coppice with standards or selective cutting (I. Schmidt, personal communication). The climate is subatlantic with a mean annual temperature of $7.5^{\circ} \mathrm{C}$. Long term mean annual precipitation of four stations around the National Park is 544-662 mm (DWD, 2008). In the study period, annual precipitation was $601 \mathrm{~mm}$ (2005), $518 \mathrm{~mm}$ (2006), and $838 \mathrm{~mm}$ (2007) (meteomedia, Germany). Parent rock is limestone covered by loess forming nutrient rich Luvisols (Guckland et al., 2009).

\section{Study plots}

In the forest area twelve study plots of $2500 \mathrm{~m}^{2}(50 \mathrm{~m} \times 50 \mathrm{~m})$ each were selected (Figure 2.1). The maximum distance between two plots was $5 \mathrm{~km}$. The plots were situated at 290-370 $\mathrm{m}$ a. s. 1., slopes ranged between 2 and $4^{\circ}$, and exposition of all plots was northeast. The study plots represented a gradient of tree species diversity with Fagus sylvatica forming the monospecific stands and mixed stands with a variable admixture of other broad-leaved deciduous species (Tilia cordata, T. platyphyllos, Fraxinus excelsior, Carpinus betulus, and Acer pseudoplatanus). The two Tilia species are combined as 'lime' in the analyses of this study, because it was not possible to reliably distinguish between them based on phenological traits and probably even hybrids exist. On some plots also A. platanoides, A. campestre, Prunus avium, Quercus robur, Q. petraea, Sorbus torminalis, and Ulmus glabra occurred but contributed little to stem number. The share of dominating tree species was calculated by crown area. Main stand characteristics (data by the whole research group if not mentioned otherwise) are presented in Table 2.1. The plot names follow the classification given by the research group and define a diversity level (DL1 to DL3), additionally they were assigned with letters a-d. The naming has no further meaning for the present study. All stand details were based on trees with a diameter at breast height $(\mathrm{dbh})>7 \mathrm{~cm}$. As a measure of diversity, we used the Shannon diversity index ( $\mathrm{H}^{\prime}$, Shannon and Weaver, 1949). $\mathrm{H}^{\prime}$ is one of the most common measures for species diversity and depends not only on the number of species present in an ecosystem, but also on their relative abundance (Magurran, 2004). Based on the number of stems, H' ranged from 0 to 1.7 for the tree layer of our study plots (Table 2.1). For stand height, the average height of the $20 \%$ highest trees was taken (tree height: M. Jacob, personal communication). Crown roughness was defined by the height difference between the mean height of the $10 \%$ highest and $10 \%$ smallest trees. Stand age was determined as median age of canopy trees (Schmidt et al., 2009; I. Schmidt, personal communication). All stand characteristics in Table 2.1 were used for the analysis of rainfall partitioning, but were only 
included in result tables when significant relationships were found. Tree species diversity, expressed as $\mathrm{H}^{\prime}$, correlated significantly $(\mathrm{p} \leq 0.05)$ with proportion of the single tree species but also with stand height, canopy roughness, lower crown limit, crown length, and gap fraction of summer 2007.

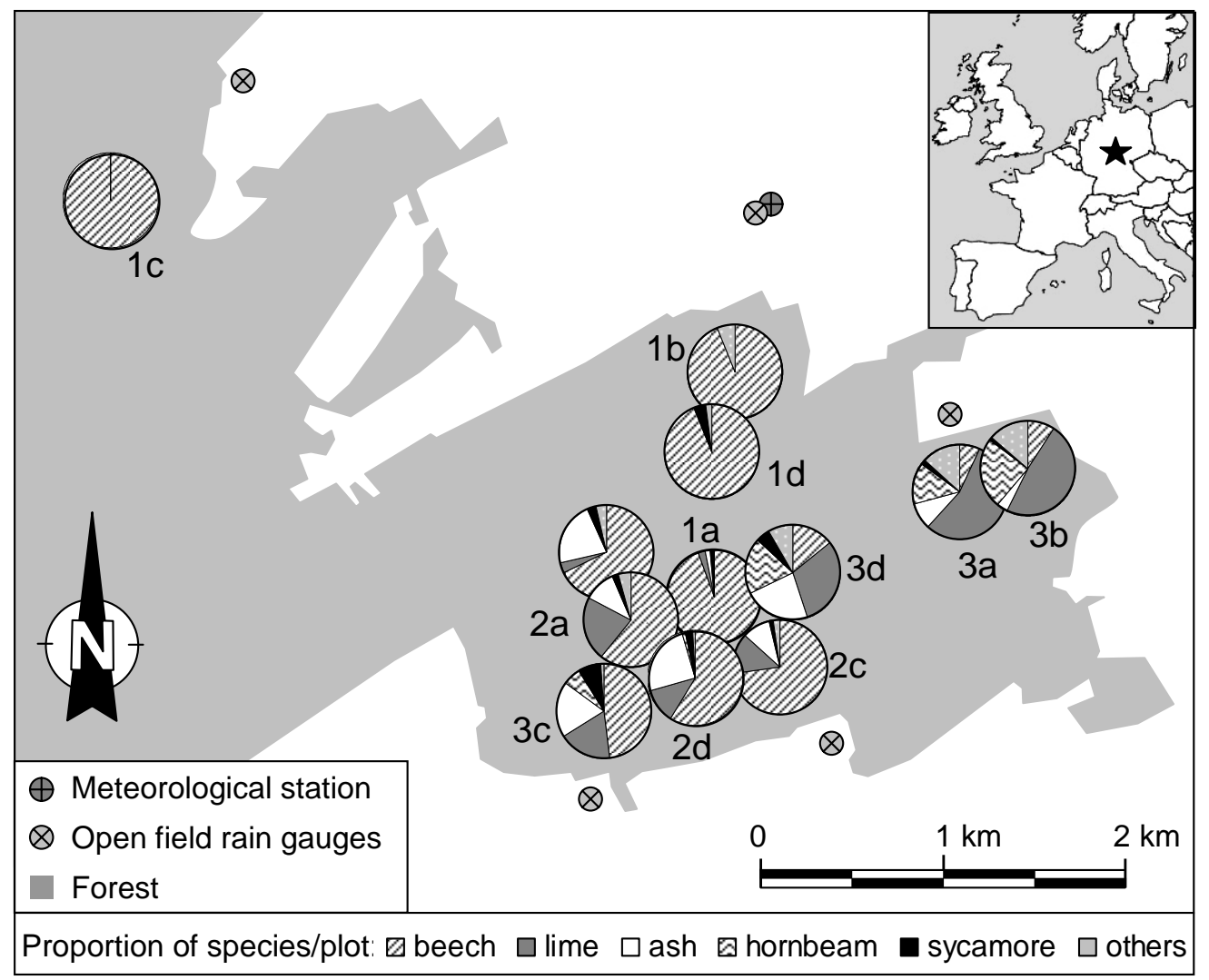

Figure 2.1 The twelve study plots in the Hainich/Germany and their species assemblages; pie charts represent locations of the plots but not plot size; additionally, locations of open field rain gauges and the meteorological station (meteomedia) are shown.

\section{Gross precipitation and rainfall partitioning}

Rainfall and other meteorological parameters were automatically recorded every hour at the meteorological station Weberstedt/Hainich (270 m a. s. 1., 51 ${ }^{\circ} 10^{\prime} \mathrm{N}, 10^{\circ} 52^{\prime} \mathrm{E}$, meteomedia, Germany), which was $900 \mathrm{~m}$ away from the nearest study plot. Individual rain events were defined as precipitation events of more than the minimum resolution of the tipping bucket rain gauge (i.e. $\geq 0.1 \mathrm{~mm}$ ) and were delimited from the following rainstorm by a dry period of more than 1 hour. These meteorological data were only used for the description of local conditions during the study period. 
Table 2.1 Forest stand characteristics of the twelve study plots of contrasting tree species diversity in the Hainich National Park (trees $>7 \mathrm{~cm}$ dbh), 'lime': Tilia cordata and T. platyphyllos.

\begin{tabular}{|c|c|c|c|c|c|c|c|c|c|c|c|c|c|c|c|c|c|c|c|c|c|c|}
\hline \multirow[b]{3}{*}{ Plot } & \multirow{3}{*}{$\begin{array}{r}\text { Shan- } \\
\text { non } \\
\text { index }\end{array}$} & \multicolumn{5}{|c|}{ Share of } & \multirow{3}{*}{$\begin{array}{r}\begin{array}{r}\text { Basal } \\
\text { area }\end{array} \\
\mathrm{m}^{2} \mathrm{ha}^{-1} \\
\end{array}$} & \multirow{3}{*}{$\begin{array}{r}\text { Stem } \\
\text { density }\end{array}$} & \multirow{3}{*}{$\begin{array}{r}\text { Mean } \\
\text { dbh } \\
\\
\mathrm{cm} \\
\end{array}$} & \multirow{3}{*}{$\begin{array}{r}\begin{array}{r}\text { Stand } \\
\text { height }{ }^{\text {a) }}\end{array} \\
\mathrm{m} \\
\end{array}$} & \multirow{3}{*}{$\begin{array}{c}\begin{array}{c}\text { Stand } \\
\text { age }^{\text {b) }}\end{array} \\
\text { years }\end{array}$} & \multirow{3}{*}{$\begin{array}{r}\text { Crown } \\
\text { diame- } \\
\text { ter } \\
\\
\mathrm{m} \\
\end{array}$} & \multirow{3}{*}{ 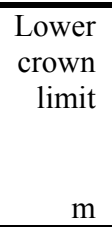 } & \multirow{3}{*}{$\begin{array}{r}\text { Crown } \\
\text { length } \\
\\
\mathrm{m} \\
\end{array}$} & \multirow{3}{*}{$\begin{array}{r}\text { Canopy } \\
\text { rough- } \\
\text { ness } \\
\\
\mathrm{m} \\
\end{array}$} & \multicolumn{3}{|c|}{$\mathrm{LAI}^{\mathrm{a})}$} & \multirow{3}{*}{$\begin{array}{r}\text { Branch } \\
\text { cover } \\
\\
\% \\
\end{array}$} & \multicolumn{3}{|c|}{ Gap fraction } \\
\hline & & beech & lime & ash & $\begin{array}{l}\text { horn- } \\
\text { beam }\end{array}$ & $\begin{array}{l}\text { syca- } \\
\text { more }\end{array}$ & & & & & & & & & & 2005 & 2006 & 2007 & & 2005 & 2006 & 2007 \\
\hline & & & & $\%$ & & & & & & & & & & & & & $\mathrm{~m}^{2} \mathrm{~m}^{-2}$ & & & & $\%$ & \\
\hline DL1a & 0.31 & 94 & 2 & 2 & 0 & 2 & 46 & 428 & 33 & 36 & 107 & 5.2 & 16 & 11 & 23 & 6.5 & 7.3 & 7.2 & 11 & 11 & 12 & 10 \\
\hline DL1b & 0.51 & 94 & 0 & 0 & 0 & 0 & 41 & 216 & 46 & 38 & 145 & 6.9 & 15 & 16 & 21 & 5.5 & 6.1 & 6.0 & 13 & 12 & 13 & 11 \\
\hline DL1c & 0.00 & 100 & 0 & 0 & 0 & 0 & 36 & 228 & 37 & 41 & 193 & 7.6 & 13 & 14 & 35 & 6.8 & 6.4 & 6.1 & 19 & 8 & 8 & 9 \\
\hline DL1d & 0.51 & 94 & 0 & 0 & 0 & 4 & 44 & 224 & 46 & 39 & 143 & 7.8 & 16 & 14 & 27 & - & - & - & 20 & 11 & 12 & 14 \\
\hline DL2a & 1.19 & 61 & 22 & 11 & 0 & 2 & 32 & 436 & 28 & 29 & 79 & 5.2 & 11 & 12 & 19 & 7.4 & 7.3 & 6.9 & 15 & 8 & 15 & 8 \\
\hline DL2b & 0.96 & 68 & 4 & 22 & 0 & 3 & 39 & 532 & 27 & 32 & 98 & 5.6 & 12 & 11 & 21 & 7.8 & 6.4 & 6.9 & 9 & 11 & 18 & 10 \\
\hline DL2c & 0.84 & 73 & 14 & 10 & 0 & 1 & 45 & 776 & 25 & 31 & 79 & 4.6 & 14 & 10 & 21 & 6.6 & 6.5 & 6.2 & 12 & 12 & 11 & 13 \\
\hline DL2d & 1.04 & 59 & 12 & 25 & 1 & 3 & 39 & 660 & 25 & 29 & 102 & 4.9 & 12 & 12 & 20 & - & - & - & 12 & 12 & 16 & 12 \\
\hline DL3a & 1.25 & 7 & 55 & 9 & 14 & 2 & 36 & 392 & 31 & 29 & 117 & 5.5 & 12 & 11 & 19 & 7.3 & 7.6 & 6.5 & 13 & 12 & 20 & 15 \\
\hline DL3b & 1.21 & 9 & 48 & 4 & 24 & 1 & 32 & 332 & 31 & 28 & 90 & 6.3 & 12 & 11 & 19 & 8.6 & 7.6 & 5.8 & 12 & 8 & 13 & 16 \\
\hline DL3c & 1.30 & 48 & 18 & 19 & 6 & 8 & 41 & 468 & 28 & 28 & 93 & 5.4 & 12 & 10 & 18 & 7.8 & 7.0 & 5.8 & 10 & 11 & 11 & 16 \\
\hline DL3d & 1.66 & 14 & 31 & 23 & 19 & 5 & 35 & 484 & 26 & 27 & 115 & 5.4 & 12 & 9 & 18 & - & - & - & 13 & 8 & 14 & 15 \\
\hline
\end{tabular}

dbh: diameter at breast height, LAI: leaf area index

a) M. Jacob, unpublished data.

b) Schmidt et al. (2009) and I. Schmidt, personal communication. 
Gross precipitation used for the rainfall partitioning analyses was measured at five open grassland areas nearby the forest (Figure 2.1) with three rain gauges each. The gauges were placed at a height of $1 \mathrm{~m}$ and were spaced $2 \mathrm{~m}$ apart. They were located at a distance of about $30-40 \mathrm{~m}$ to the forest edge as close as possible to the study plots in the forest $(200-1200 \mathrm{~m}$ distance), and situated at about the same altitude. The rain gauges consisted of a plastic bottle and a funnel with a vertical rim of $10.5 \mathrm{~cm}$ in diameter attached to a metal rod. A table tennis ball was placed in the funnel to reduce evaporation.

Within each of the study plots in the forest, three transects of $30 \mathrm{~m}$ length were chosen randomly (without crossings) along which throughfall collectors were installed. Each plot was equipped with 15 rain gauges (five on each transect) that were built identically to the rain gauges in the open area. Collector positions along transects were defined randomly with a minimum distance of $4 \mathrm{~m}$ between two collectors. None of the rain gauges had a wind shield, which may lead to an underestimation of rainfall (Groisman and Legates, 1994). According to these authors the associated error is largest in mountainous areas with prevalent snowfall and high wind speeds. We worked in flat terrain, snowfall was negligible and wind speeds were usually low to moderate; therefore we assume that errors may be small.

However, two heavy storms caused windthrow on or nearby three of our study plots. Throughfall collectors with a remaining canopy cover less than $60 \%$ or with dead trees above were removed from the analysis. This resulted in 13 remaining gauges on plot DL1c (from May 2006 onwards), and 8 and 14 samplers for plot DL3a and DL1d, respectively (after January 2007). In this way, we excluded storm affected rainfall gauge data, and mean throughfall of the plots did not show apparent changes to the time before storms. Minor changes in throughfall of stands affected by windthrow were also documented by Neal et al. (1993).

Stemflow of the five most abundant tree species was measured with 50 collectors. Trees with a dbh range of 8-77 $\mathrm{cm}$ were selected adjacent to the plots. Since beech is known to have high stemflow volumes and it is the most abundant tree species on our study plots, we selected more beech trees (20 individuals) than other tree species. The other species were represented each by six (sycamore) or eight individuals (ash, hornbeam, and lime). Stemflow was collected using spiral collars (PU foam, internal diameter $\sim 7 \mathrm{~cm}$ ) attached to stems and sealed with silicone sealant. Flexible tubes led the water into containers. Stemflow volume per plot area was calculated based on species-specific regressions between dbh and stemflow volume per measuring period, combined with stem number and dbh of trees on the study plots. When 
there was no persistent correlation between dbh and stemflow for a certain species (ash, lime, and sycamore), an average value of the stemflow volume of all measured trees of this species was taken. For less frequent species the average stemflow value of ash, lime, and sycamore was used. To allow a meaningful comparison of different plots, stemflow estimations ignored the tree loss at some of the sites. During some periods with high rainfall amounts, stemflow containers of a few trees overflowed. These values were estimated on the basis of polynomial relations between stemflow and gross precipitation for each tree.

Gross precipitation, throughfall, and stemflow were measured manually every two weeks from May 2006 to August 2007. Additionally, throughfall was measured in summer 2005 (May to September, same frequency). Measured water volumes were summed up for the different seasons as delineated from canopy cover estimates by hemispherical photography. Values for interception loss were derived by subtracting throughfall and estimated stemflow from gross precipitation. Stemflow and therewith interception cannot be given for summer 2005 , since only throughfall was measured in this period. Because snow was only a minor part of gross precipitation in winter 2006/07, snow events were included in the two-week measurements without specific consideration (no snow samplers were used).

\section{Gap fraction, branch cover, and LAI}

For determination of gap fraction in summer and branch cover in winter, hemispherical photographs were taken vertically upward above each rain gauge on the 15 randomly located points per plot with a high resolution digital camera (Minolta Dimage Xt, Japan). The camera had a $185^{\circ}$ fish-eye lens and was placed in a levelling device (Regent Instruments, Canada) that in turn was placed on top of a tripod. To follow seasonal changes in foliation, photos were taken at several dates (cloudy sky or low sun elevation). Images were analysed for gap fraction and branch cover in a $10^{\circ}$ circular area directly above the gauges with CanEye 5.0 (INRA, 2007).

In the studied forest stands, trees began foliating in early April and foliation was completed in the second half of May ('spring'). Fully developed foliation in summer remained until the beginning of September when leaf shedding ('autumn') started. The trees were leafless from December to beginning of April ('winter'). The exact time spans for each season during the whole study period are given in Table 2.2. Gap fraction was similar in all three years and between 8 and $20 \%$ during summer (Table 2.1). Branch cover of the study plots ranged 
between 9 and 20\%, analysed by winter photographs. Measuring points affected by windthrow were removed from the data as it was done for the rainfall analyses.

Leaf area index (LAI, leaf area in $\mathrm{m}^{2} \mathrm{~m}^{-2}$ ) for nine of the twelve study plots was based on leaf biomass which was collected next to the rain gauges (M. Jacob, unpublished data). Litter traps were emptied several times during autumnal leaf shedding. Leaves of all species were scanned and leaf area was analysed using WinFOLIA (Regent Instruments, Canada). Subsequently, all leaves were dried and weighted and the specific leaf area (SLA) was calculated. LAI was obtained by multiplying stand leaf biomass per species with the speciesspecific average of SLA (M. Jacob, unpublished data).

\section{Statistical analyses}

Since not all data were normally distributed, we used medians and interquartile ranges (IQR) divided by medians as measures of central tendency and dispersion in our study. The relation between rainfall partitioning and stand characteristics was analysed using Spearman's rank correlation $\left(\mathrm{r}_{\mathrm{s}}\right)$. Additionally, we used multiple linear regressions (without interactions), although data were not always normally distributed and the number of twelve plots is rather low. These results have to be interpreted with care. Reported coefficients of determination are adjusted $\mathrm{R}^{2}$. Combinations of parameters were excluded when the model showed multicollinearity (variance inflation factor $>10$, Chatterjee and Price, 1991) and when influential points existed. Influential points are defined by high leverage effect and outlier characteristic. High leverage points were chosen when their leverage was $>2 \mathrm{p} / \mathrm{n}$, with $\mathrm{p}$ as the sum of leverages (Faraway, 2002). Outliers were depicted by cooks distance $(>1)$. Differences of rainfall partitioning among seasons and study plots were tested with two-way ANOVA. The statistical analysis was conducted with R version 2.7.1 (R Development Core Team, 2008). 
Table 2.2 Rainfall characteristics and other meteorological conditions at the meteorological station Weberstedt/Hainich (270 m a. s. 1 .) during the study period (Meteomedia, Germany).

\begin{tabular}{|c|c|c|c|c|c|c|c|c|c|c|c|c|c|}
\hline \multirow[b]{2}{*}{ Period observed } & $\begin{array}{r}\text { Number of } \\
\text { days } \\
\text { observed }\end{array}$ & $\begin{array}{r}\text { Gross } \\
\text { precipi- } \\
\text { tation }\end{array}$ & $\begin{array}{r}\text { Number } \\
\text { of events }\end{array}$ & $\begin{array}{l}\text { Events } \\
>1 \mathrm{~mm}\end{array}$ & $\begin{array}{r}\text { Number } \\
\text { of events } \\
\text { per day }\end{array}$ & amount & $\begin{array}{l}\text { verage ev } \\
\text { duration }\end{array}$ & intensity & \multirow{2}{*}{ 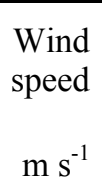 } & \multirow{2}{*}{$\begin{array}{r}\text { Air } \\
\text { tempe- } \\
\text { rature } \\
{ }^{\circ} \mathrm{C}\end{array}$} & \multirow{2}{*}{$\begin{array}{r}\text { Vapour } \\
\text { pressure } \\
\text { deficit } \\
\mathrm{kPa}\end{array}$} & \multirow{2}{*}{$\begin{array}{r}\text { Relative } \\
\text { humidity } \\
\%\end{array}$} & \multirow{2}{*}{$\begin{array}{r}\begin{array}{r}\text { Global } \\
\text { radiation } \\
\mathrm{MJ} \mathrm{m}^{-2} \mathrm{~d}_{1}^{-}\end{array}\end{array}$} \\
\hline & $\mathrm{n}$ & $\mathrm{mm}$ & $\mathrm{n}$ & $\%$ & $\mathrm{nd}^{-1}$ & $\mathrm{~mm}$ & $\mathrm{~h}$ & $\mathrm{~mm} \mathrm{~h}^{-1}$ & & & & & \\
\hline 19.05.-07.09.05 (Summer) & 112 & 207 & 84 & 80 & 0.8 & 2.5 & 2.7 & 0.9 & 2.6 & 17 & 0.6 & 77 & 18 \\
\hline 19.05.-06.09.06 (Summer) & 111 & 228 & 91 & 76 & 0.8 & 2.5 & 2.8 & 0.7 & 2.5 & 17 & 0.6 & 76 & 19 \\
\hline 07.09.-01.12.06 (Autumn) & 86 & 88 & 60 & 73 & 0.7 & 1.5 & 3.1 & 0.4 & 3.2 & 12 & 0.3 & 84 & - \\
\hline 02.12.06-05.04.07 (Winter) & 125 & 204 & 120 & 83 & 1.0 & 1.7 & 4.0 & 0.4 & 4.0 & 5 & 0.2 & 86 & 6 \\
\hline 06.04.-16.05.07 (Spring) & 41 & 49 & 18 & 83 & 0.4 & 2.7 & 3.8 & 0.6 & 2.9 & 12 & 0.5 & 69 & 18 \\
\hline 17.05.-22.08.07 (Summer) & 98 & 359 & 79 & 85 & 0.8 & 4.5 & 3.5 & 1.1 & 2.7 & 17 & 0.5 & 79 & 18 \\
\hline
\end{tabular}




\subsection{RESULTS}

\section{Magnitudes and seasonal differences of rainfall partitioning}

In summer 2007, gross precipitation was above long-term mean and it was $73 \%$ higher than in summer 2005 and 57\% higher than in summer 2006 (Table 2.2). Average duration per event and average number of rainfall events per day were highest during winter, whereas average rainfall event amount and intensity were high during summer and low during winter. Additionally, in winter, wind speed and humidity in the study area were higher, and air temperature, vapour pressure deficit, and global radiation lower than in summer. Gross precipitation volume was relatively similar at our five open field sites during the study period. However, rainfall volume given by the nearby meteorological station was always lower (around 10\% compared to the closest of our measuring points), probably depending on different collection equipment.

Throughfall median of the twelve study plots varied between 54 and $78 \%$ of gross precipitation in the study period (Table 2.3). Differences among seasons were larger than differences among the study plots. The largest throughfall differences among seasons were observed on two diverse plots (DL3b and DL3d, 18 and 17\% of gross precipitation, respectively). A monospecific beech plot (DL1c) had almost the same relative throughfall (67-68\%) in all three summers, whereas all other plots showed differences among the three summers. Throughfall was highest on most sites in summer 2007. This was the period with the most intense rainfalls, which were both extra-ordinary long and strong, and it was also the windiest season during the whole study period (Table 2.2). The lowest throughfall percentages were observed for most of the study plots in autumn 2006, but for the three plots with highest tree species diversity in spring 2007. Winter throughfall fractions showed the highest similarity among the plots and were not generally higher than in summer (Table 2.3) despite the fact that foliage was missing.

Stemflow of the study plots was between 0.4 and $6.3 \%$ in the study period and varied more between seasons than between plots (Table 2.3). The largest differences appeared between summer 2006 and summer 2007. Beech and hornbeam had more stemflow than lime, ash, and sycamore and showed a strong positive (power) relationship between dbh and stemflow (Figure 2.2a). The three other tree species showed no significant correlation between these parameters (Figure 2.2b). However, there was the tendency that sycamore and in some 
periods also lime had an inverse relationship between stemflow and dbh, i.e. smaller trees yielded more stemflow than larger trees.

Table 2.3 Rainfall partitioning into throughfall, stemflow, and interception in percent of gross precipitation (PG, median of the five open field locations) at the twelve study plots during the study periods from 2005 to 2007.

\begin{tabular}{|c|c|c|c|c|c|c|c|c|c|c|c|c|c|c|c|c|}
\hline \multirow[b]{2}{*}{ Plot } & \multicolumn{6}{|c|}{ Throughfall (\% of Pg) } & \multicolumn{5}{|c|}{ Stemflow (\% of Pg) } & \multicolumn{5}{|c|}{ Interception (\% of Pg) } \\
\hline & 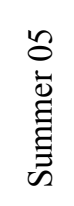 & 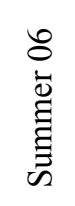 & 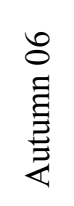 & 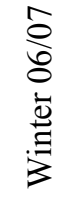 & $\begin{array}{l}5 \\
0 \\
0 \\
: \\
\vdots \\
0 \\
0\end{array}$ & 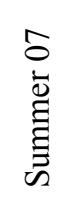 & 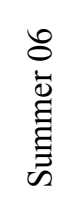 & $\begin{array}{l}\text { ठ } \\
\text { 奉 } \\
\text { 娄 }\end{array}$ & 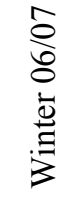 & $\begin{array}{l}\hat{\sigma} \\
\text { o. } \\
. \\
\hat{n}\end{array}$ & 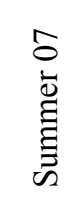 & 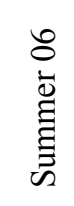 & $\begin{array}{l}\text { ठ } \\
\text { 䒠 } \\
\text { 王 }\end{array}$ & 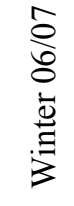 & $\begin{array}{l}5 \\
0 \\
.0 \\
\text { के } \\
\text { के }\end{array}$ & 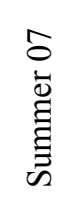 \\
\hline $\mathrm{Pg}(\mathrm{mm})$ & 226 & 278 & 120 & 329 & 76 & 420 & 278 & 120 & 329 & 76 & 420 & 278 & 120 & 329 & 76 & 420 \\
\hline DL1a & 64 & 59 & 59 & 65 & 59 & 72 & 1.1 & 4.0 & 3.8 & 3.8 & 6.2 & 39 & 37 & 31 & 37 & 22 \\
\hline DL1b & 68 & 66 & 62 & 66 & 67 & 74 & 1.4 & 2.7 & 2.7 & 3.9 & 5.5 & 32 & 36 & 32 & 29 & 20 \\
\hline DL1 & 67 & 68 & 57 & 69 & 59 & 67 & 1.4 & 2.5 & 2.6 & 3.3 & 5.9 & 31 & 40 & 29 & 38 & 27 \\
\hline & 70 & 66 & 64 & 75 & 72 & 74 & 1.6 & 2.9 & 2.9 & 4.3 & 6.3 & 32 & 3. & 22 & 24 & 20 \\
\hline$a$ & 71 & 63 & 62 & 68 & 64 & 74 & 0.6 & 2.0 & 2.4 & 2.3 & 3.1 & 36 & 36 & 29 & 34 & $2 ?$ \\
\hline D & 72 & 65 & 62 & 65 & 66 & 72 & 0.8 & 3.0 & 3.5 & 3.4 & 3.8 & 34 & 35 & 31 & 31 & 25 \\
\hline DL2c & 62 & 58 & 54 & 65 & 59 & 66 & 0.7 & 4.9 & 4.7 & 4.0 & 4.8 & 41 & 41 & 30 & 37 & 29 \\
\hline DL2d & 74 & 66 & 61 & 69 & 72 & 75 & 0.7 & 3.5 & 3.7 & 3.3 & 3.7 & 33 & 35 & 28 & 25 & 21 \\
\hline & 7. & 69 & 66 & 71 & 64 & 76 & 0.4 & 0.4 & 1.4 & 1.4 & 2.0 & 30 & 34 & 28 & 35 & 2. \\
\hline DL3b & 67 & 68 & 63 & 69 & 59 & 77 & 0.6 & 0.4 & 1.6 & 1.6 & 2.2 & 31 & 37 & 30 & 40 & 2 \\
\hline DL3c & 78 & 68 & 65 & 67 & 68 & 75 & 0.6 & 2.1 & 2.7 & 2.6 & 3.2 & 31 & 33 & 30 & 29 & 21 \\
\hline DL3d & 72 & 67 & 62 & 65 & 60 & 77 & 0.5 & 0.8 & 1.8 & 1.9 & 2.4 & 33 & 37 & 33 & 38 & 21 \\
\hline Median & 71 & 66 & 62 & 68 & 64 & 74 & 0.7 & 2.6 & 2.7 & 3.3 & 3.7 & 33 & 36 & 30 & 34 & 2. \\
\hline
\end{tabular}
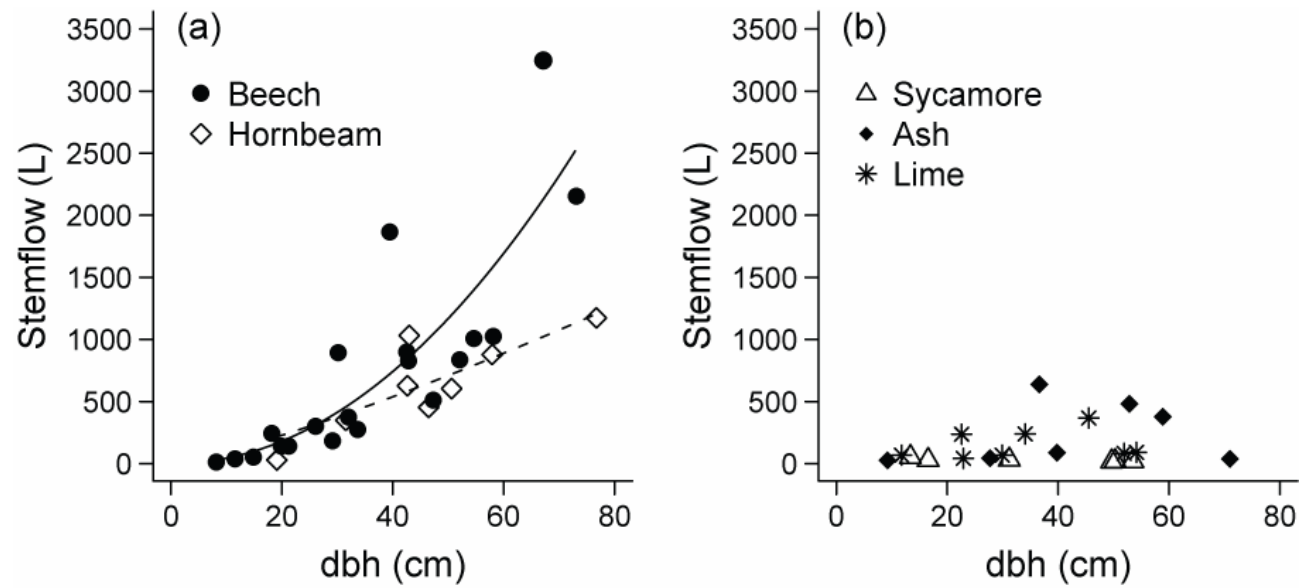

Figure 2.2 Stemflow in summer 2007 of $(a)$ beech $\left(n=20, y=0.41 x^{2.04}\right)$ and hornbeam $(n=8$, $\left.y=5.59 x^{1.24}\right)$, and $(b)$ of sycamore $(n=6)$, ash $(n=8)$, and lime $(n=8)$. 
Consequently, interception was between 20 and 41\% during the study period (Table 2.3) and differences between seasons were more pronounced than between stands. Median interception was with $21 \%$ exceptionally low in summer 2007 , whereas the median of all plots was between 30 and $36 \%$ in the other four study seasons. Differences between minimum and maximum interception of the plots were almost always only $8-11 \%$ of gross precipitation in a given season, just in spring the difference was larger (16\%). The separation of gross precipitation into stemflow and throughfall showed seasonal differences. In summer 2006, the stemflow to throughfall ratio was very low, which means stemflow accounted for only a minor part of non-intercepted water. In contrast, this ratio was much higher in spring and summer 2007.

\section{Rainfall partitioning in relation to stand characteristics and tree species diversity}

The relationship between throughfall and stand characteristics varied among seasons. In three (summer 2005 and 2007, autumn 2006) out of six studied periods, throughfall correlated significantly with tree species diversity (Table 2.4). The strongest link between Shannon diversity index $\left(\mathrm{H}^{\prime}\right)$ and throughfall was observed in summer 2007 when throughfall increased highly significantly with tree species diversity $\left(r_{s}=0.74, p=0.008\right.$; see also Figure 2.3). The increase of throughfall with $\mathrm{H}^{\prime}$ was paralleled by increasing hornbeam and decreasing beech proportion. The high Spearman's correlation coefficient for hornbeam proportion has to be taken with care because hornbeam occurs only on five plots. A similar problem exists for all other species, except beech. Also gap fraction above the rain gauges explained throughfall differences $\left(\mathrm{r}_{\mathrm{s}}=0.74, \mathrm{p}=0.006\right)$. Shannon diversity index, proportion of hornbeam and beech, and gap fraction were closely correlated. In summer 2005, increasing Shannon index as well as increasing sycamore and ash proportion correlated positively with throughfall. Remarkably, Shannon index was the only characteristic that correlated significantly with throughfall in both summers. In summer 2006, mean crown diameter and hornbeam proportion yielded high correlation coefficients. Throughfall in autumn showed the same tendency but less pronounced than in summer 2007: with increasing tree species diversity more water dripped through the canopy. For throughfall in winter and spring, we could not find a significant explanatory variable. Because often many different variables were significantly correlated with throughfall, only one variable seemed to be not enough to account for the variability in throughfall among the plots. Another explanation could also be the close correlation between some parameters. To test whether combinations of parameters play a role, multiple regressions were carried out. 
Multiple linear regressions showed high $\mathrm{R}_{\text {adj- }}^{2}$ and low p-values and significant combinations of two parameters explaining throughfall percentages could be found for all seasons except winter (Table 2.5). Shannon index was included in the most significant combination both in summer 2007 and autumn 2006. Additionally, mean dbh of the stands, crown diameter, and proportion of ash and beech were important. Although species show temporal differences in foliating in spring and leaf shedding in autumn, we could not detect any species as the controlling factor in the one-factor analysis for spring. However, in multiple regressions the combination of ash proportion and mean dbh explained throughfall differences significantly for spring.

Table 2.4 Spearman's rank correlation coefficients $\left(r_{s}\right)$ between throughfall and stand characteristics of the 12 study plots in different study periods. Significant $(\mathrm{p} \leq 0.05)$ correlations are highlighted in bold. Only stand parameters that show a significant relationship to throughfall are shown.

\begin{tabular}{|c|c|c|c|c|c|c|c|c|c|c|}
\hline & \multicolumn{2}{|c|}{ Summer 05} & \multicolumn{2}{|c|}{ Summer 06} & \multicolumn{2}{|c|}{ Autumn 06} & \multirow{2}{*}{$\begin{array}{c}\text { Winter } 06 / 07 \\
0.13\end{array}$} & \multirow{2}{*}{$\frac{\text { Spring } 07}{0.08}$} & \multicolumn{2}{|c|}{ Summer 07} \\
\hline Shannon index & 0.61 & $*$ & 0.26 & & 0.64 & $*$ & & & 0.74 & $* *$ \\
\hline Beech proportion & -0.54 & . & -0.41 & & -0.66 & * & -0.31 & -0.01 & -0.79 & $* *$ \\
\hline Lime proportion & 0.30 & & 0.25 & & 0.50 & . & 0.14 & -0.27 & 0.63 & $*$ \\
\hline Ash proportion & 0.61 & $*$ & -0.25 & & 0.11 & & -0.25 & 0.25 & 0.24 & \\
\hline Hornbeam proportion & 0.38 & & 0.60 & * & 0.54 & . & 0.30 & -0.14 & 0.90 & $* * *$ \\
\hline Sycamore proportion & 0.70 & $*$ & -0.13 & & 0.54 & . & 0.03 & 0.56 & 0.29 & \\
\hline Basal area & -0.30 & & -0.51 & . & -0.34 & & -0.36 & 0.20 & -0.47 & \\
\hline Stem density & 0.25 & & -0.55 & . & -0.23 & & -0.50 & 0.01 & -0.17 & \\
\hline Stand height & -0.45 & & -0.15 & & -0.47 & & 0.04 & 0.09 & -0.71 & $*$ \\
\hline Crown diameter & -0.08 & & 0.65 & $*$ & 0.35 & & 0.49 & 0.04 & 0.13 & \\
\hline Lower crown limit & -0.48 & & -0.28 & & -0.36 & & -0.14 & 0.13 & -0.54 & . \\
\hline Canopy roughness & -0.56 & . & -0.12 & & -0.50 & . & -0.01 & -0.13 & -0.72 & $*$ \\
\hline LAI & 0.42 & & 0.25 & & - & & - & - & -0.43 & . \\
\hline Gap fraction & 0.15 & & 0.19 & & - & & - & - & 0.74 & $* *$ \\
\hline
\end{tabular}

. $\mathrm{p} \leq 0.1, * \mathrm{p} \leq 0.05, * * \mathrm{p} \leq 0.01$, and $* * * \mathrm{p} \leq 0.001$

Table 2.5 Relation between throughfall and stand characteristics of the twelve study plots (multiple linear regressions); only the most significant combination of two variables for each study period is presented.

\begin{tabular}{llll}
\hline Study period & Variable 1 & Variable 2 & $\mathrm{R}_{\text {adj }}^{2}$ \\
\hline Summer 05 & Ash proportion $(* *)$ & Mean dbh $()$. & 0.49 \\
Summer 06 & Crown diameter $(* *)$ & Beech proportion $(* *)$ & $0.69 * *$ \\
Autumn 06 & Shannon index $(* *)$ & Mean dbh $(*)$ & $0.53 *$ \\
Winter 06/07 & - & - & \\
Spring 07 & Ash proportion $(* *)$ & Mean dbh $(*)$ & $0.51 *$ \\
Summer 07 & Shannon index $(* *)$ & Mean dbh $(*)$ & $0.63 * *$ \\
\hline
\end{tabular}

$\cdot \mathrm{p} \leq 0.1, * \mathrm{p} \leq 0.05$, and $* * \mathrm{p} \leq 0.01$ 

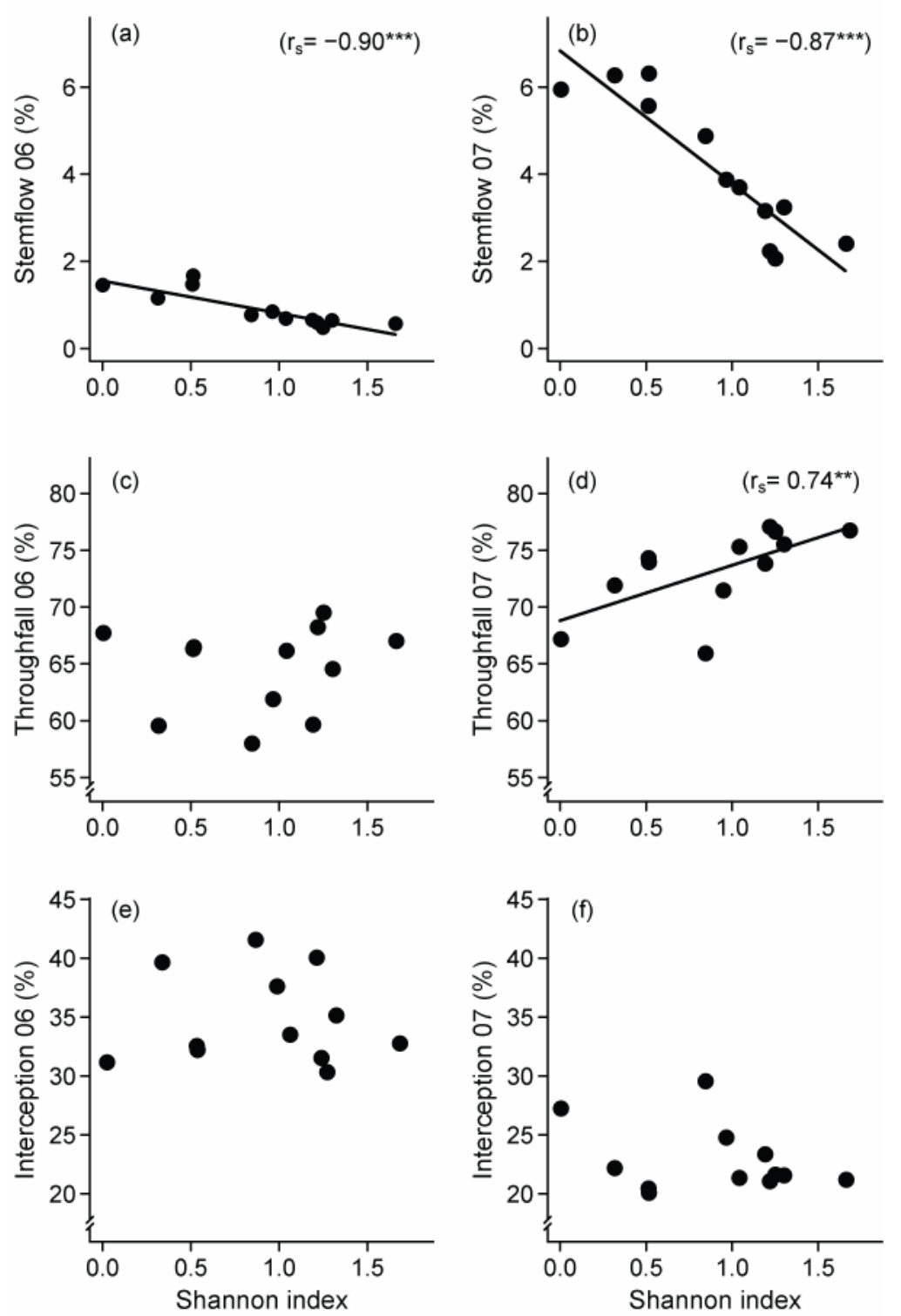

Figure 2.3 Rainfall partitioning in relation to tree species diversity of the 12 study plots in summer 2006 and summer 2007. (a) and (b) stemflow, (c) and (d) throughfall, (e) and (f) interception in percent of gross precipitation $(* * \mathrm{p} \leq 0.01$, and $* * * \mathrm{p} \leq 0.001)$.

Stemflow per plot showed a strong decrease with increasing tree species diversity during all investigated seasons. In both summers, 2006 and 2007, proportion of beech $\left(r_{s}>0.92\right.$, $\mathrm{p}<0.001)$ explained most of the variation among plots, although also Shannon index correlated significantly with stemflow $\left(\mathrm{r}_{\mathrm{s}}<-0.87, \mathrm{p}<0.001\right)$. However, in spring, autumn, and winter, basal area or lower crown limit explained most significantly the distribution of stemflow amounts $\left(\mathrm{r}_{\mathrm{s}}>0.71, \mathrm{p}<0.001\right)$. 
Since stemflow showed the opposite trend to throughfall for the twelve study plots, this somehow evened out effects of tree species diversity and other stand characteristics on interception level (see e.g. Figure 2.3: summer 2007). However, beech dominated plots had sometimes only inter-mediate throughfall, but always the highest stemflow percentages.

\section{Spatial heterogeneity of throughfall along the beech to mixed forest gradient}

Interquartile range (IQR) to median ratio as a measure of throughfall heterogeneity ranged between 0.03 and 0.26 per study plot (Table 2.6). Heterogeneity was lower in autumn and winter and higher in spring and all three summers. There is no clear correlation between throughfall heterogeneity and Shannon index (Table 2.7). However, the plot with the highest tree species diversity (DL3d) showed always high spatial variability of throughfall, whereas both a beech dominated plot (DL1a) and a diverse plot (DL3a) had more similar throughfall values for all rainfall collectors. Also, no other stand characteristics explained constantly the differences in spatial throughfall heterogeneity of the stands. In some periods, explanatory parameters for increasing heterogeneity were decreasing stand height and canopy roughness.

Table 2.6 Spatial heterogeneity of throughfall on the twelve study plots (interquartile range to median ratio).

\begin{tabular}{|c|c|c|c|c|c|c|}
\hline Plot & 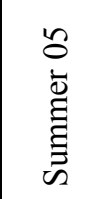 & 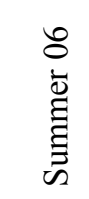 & $\begin{array}{l}\text { ठ } \\
\text { 䒠 } \\
\text { 至 }\end{array}$ & $\begin{array}{l}\hat{0} \\
0 \\
0 \\
\stackrel{0}{0} \\
\stackrel{3}{3}\end{array}$ & $\begin{array}{l}\hat{0} \\
\text { ob } \\
\text { : } \\
\text { के }\end{array}$ & $\begin{array}{l}\text { o } \\
\dot{\Xi} \\
\text { 音 } \\
\text { के }\end{array}$ \\
\hline $\begin{array}{l}\mathrm{Pg} \\
(\mathrm{mm})\end{array}$ & 226 & 278 & 120 & 329 & 76 & 420 \\
\hline DL1a & 0.10 & 0.11 & 0.05 & 0.04 & 0.12 & 0.08 \\
\hline DL1b & 0.12 & 0.12 & 0.07 & 0.07 & 0.10 & 0.11 \\
\hline DL1c & 0.10 & 0.15 & 0.14 & 0.05 & 0.18 & 0.12 \\
\hline DL1d & 0.11 & 0.08 & 0.07 & 0.06 & 0.25 & 0.11 \\
\hline DL2a & 0.12 & 0.13 & 0.04 & 0.10 & 0.11 & 0.08 \\
\hline DL2b & 0.09 & 0.07 & 0.06 & 0.06 & 0.11 & 0.15 \\
\hline DL2c & 0.12 & 0.08 & 0.06 & 0.07 & 0.09 & 0.10 \\
\hline DL2d & 0.17 & 0.15 & 0.06 & 0.12 & 0.14 & 0.15 \\
\hline DL3a & 0.09 & 0.08 & 0.04 & 0.07 & 0.07 & 0.07 \\
\hline DL3b & 0.19 & 0.15 & 0.09 & 0.11 & 0.08 & 0.14 \\
\hline DL3c & 0.13 & 0.08 & 0.03 & 0.10 & 0.16 & 0.07 \\
\hline DL3d & 0.23 & 0.18 & 0.14 & 0.07 & 0.26 & 0.14 \\
\hline Median & 0.12 & 0.12 & 0.06 & 0.07 & 0.12 & 0.11 \\
\hline
\end{tabular}


Table 2.7 Spearman's rank correlation coefficients $\left(r_{s}\right)$ between throughfall heterogeneity (interquartile range/median ratio) and stand characteristics of the twelve study plots. Significant $(\mathrm{p} \leq 0.05)$ correlations are highlighted in bold. Only stand parameters that show a significant relationship to throughfall heterogeneity are shown.

\begin{tabular}{lrccrcc}
\hline & Summer 05 & Summer 06 & Autumn 06 & Winter 06/07 & Spring 07 & Summer 07 \\
\hline Shannon index & 0.52 & 0.10 & -0.20 & $0.52 \cdot$ & -0.05 & -0.10 \\
Beech proportion & -0.41 & -0.05 & 0.17 & $-0.57 \cdot$ & 0.29 & 0.04 \\
Hornbeam proportion & $0.53 \cdot$ & 0.34 & 0.16 & 0.48 & -0.09 & 0.09 \\
Sycamore proportion & 0.24 & -0.22 & -0.32 & 0.08 & 0.52 & -0.05 \\
Stand height & $\mathbf{- 0 . 5 9} *$ & -0.22 & 0.20 & $-0.55 *$ & 0.11 & 0.13 \\
Canopy roughness & $\mathbf{- 0 . 6 1} *$ & -0.25 & 0.27 & $\mathbf{- 0 . 6 5} *$ & 0.08 & 0.17 \\
\hline
\end{tabular}

. $\mathrm{p} \leq 0.1$ and $* \mathrm{p} \leq 0.05$

\subsection{DISCUSSION}

\section{Magnitudes and seasonal differences of rainfall partitioning}

Both throughfall and stemflow fractions measured in this study were at the lower end and sometimes even below the range of values reported for beech and beech-dominated forests by Peck (2004). These comparatively low percentages could be due to overall low gross precipitation and low rainfall intensities in the study region. Other studies that reported similar low percentages for comparable forest sites were also mostly carried out under low precipitation conditions (Einsele et al., 1983; Nordén, 1991; Chang and Matzner, 2000; Dalsgaard, 2008). Consequently, the observed interception range of 20 to $41 \%$ over all our plots and study periods was in the (upper) range of other studies (Leuschner and Rode, 1999; reviews by Forgeard et al., 1980, Augusto et al., 2002, and Peck, 2004).

The observation that interception in summer was not lower than in winter has also been reported by other authors. Reviews showed that interception in beech and other broad-leaved deciduous forests has the tendency to be lower in winter, but this difference is not significant and sometimes even completely absent (Mitscherlich, 1981; Peck, 2004; see also Reynolds and Henderson, 1967 and literature therein). Mitscherlich (1981) related this to the fact that in Central Europe winter precipitation is often less than in summer and rainfall intensity is higher in summer than in winter time. Also other meteorological variables showed differences between summer and winter. Higher wind speeds, which often occur in winter, are known to enhance evaporation rate of intercepted water that is temporarily stored on branches and trunks (Herbst et al., 2008). Temporal distribution of rain events affects the number of canopy 
wetting and drying cycles, thus, throughfall is less if rainfall is intermittent (Reynolds and Henderson, 1967; Zeng et al., 2000; Link et al., 2004). Accordingly, winter had smaller but more rainfall events than summer during our study. These meteorological aspects probably counterbalanced the reduced storage capacity of the leafless canopy and could therefore explain the relatively high interception loss in winter seasons.

Our data also suggest that the differences in rainfall partitioning among the three observed summers arose from different rainfall conditions, explicitly rainfall intensity. There is a linear trend between throughfall and rainfall intensity of the summer seasons. Interception losses are greater when raindrops are small, because large raindrops shake the leaves and storage capacity can not be achieved (Horton, 1919; Heuveldop, 1973; Calder, 1996). In addition, evaporation rates are greater during low intensity rain events (Calder, 1996; André, 2007). The relationship between different interception percentages of different periods and rainfall intensity was reported in many studies (e.g. Heuveldop, 1973; Llorens et al., 1997; Staelens et al., 2007).

Since the water balance of forest ecosystems is sensitive to temporal rainfall distribution it is important for investigating the effects of changing climate conditions. Not only a decrease in rainfall amounts but also in rain intensity could lead to less water input to the soil because of enhanced interception. The Hainich area is characterised by low precipitation and could thus be sensitive to reductions in rain amounts or changing rainfall intensities during vegetation periods as predicted for the future (Bates et al., 2008).

\section{Rainfall partitioning in relation to stand characteristics and tree species diversity}

The studied stands differed in respect to a series of structural characteristics. Whether a characteristic is an effect of a certain tree species, species diversity, or other influences like former management practices is difficult to separate. They are all combined: tree species diversity correlated with several stand characteristics, as for example stand height and canopy roughness. However, no clear relationship between LAI and tree species diversity was observed (M. Jacob, personal communication). Although beech is known for its high LAI (Leuschner et al., 2006), the mixed stands had similar high leaf area index as the monospecific beech stands. This could be due to diversity effects on canopy space occupation. The investigated diversity gradient in this study corresponded at the same time to a beech (or any other species) gradient and all effects could as well be effects of a certain species. However, required tree species combinations are difficult or even impossible to find in 
sufficient numbers in nature (Leuschner et al., 2009). Recently established tree diversity experiments are promising for the future. Besides, beech stands with a variable admixture of other species are among the most important types of mixed deciduous species stands in Central European forestry.

With respect to diversity effects, Scherer-Lorenzen et al. (2005) emphasised the following two statements. According to Hector et al. (2000) there is no 'magic effect of numbers of species per se', instead, any effect would arise from functional differences among species and from species interactions. Without these functional differences between species, no relationship between species richness and ecosystem processes could be found (Lawton et al., 1998). The impact of biodiversity can be realized by how it alters the structural and functional properties of a forest stand, such as its aerodynamic roughness and LAI. Baldocchi (2005) argued that whether or not biodiversity affects for example evaporation may come down to an argument on semantics. When functional plant attributes affect a process one may argue that functional diversity has a larger effect than species diversity. On the other hand, evolutionary pressures have forced different species to adopt different functional features (Baldocchi, 2005). Therefore it is only consequential that we found correlations with diversity and certain stand characteristics at the same time.

Throughfall differences among the study plots correlated with several stand parameters during the investigated seasons. There was no single characteristic that had always the strongest explanatory power (Table 2.4). However, tree species diversity was the only variable that could explain throughfall in three out of six periods. In high-rainfall summer 2007, stand height, crown length, and crown roughness strongly influenced throughfall as well. Since rainfall events were very intense, evaporation was probably very low, but higher in canopies of large and rough stands. Greater roughness leads to a more effective turbulent energy exchange with the atmosphere (e.g. Cionco, 1972; Kelliher et al., 1993) what could be responsible for high evaporation. In the investigated summer with lowest rainfall intensity (2006), crown diameter was the most important variable for determining throughfall differences. Crown characteristics may become relatively more important when evaporation is already high.

Also in multiple linear regressions, Shannon index played an important role (Table 2.5). In this analysis, the mean dbh of the plots was a significant explanatory variable for throughfall differences among plots in many seasons. However, it seemed to be only a supporting 
variable, since it did not explain throughfall differences in the one-factor analysis in any season.

Our study showed that several stand characteristics together control throughfall percentage and that they interact very closely or sometimes even level each other out. Shannon diversity index seemed to reflect differences among species quite well, as it correlated positively with throughfall in several seasons. Other diversity indices (e.g. Pretzsch, 1996; Simpson, 1949) correlated with rainfall partitioning in the same way as the Shannon diversity index, therefore we did not include them in this publication. To our knowledge, only few studies exist that compare several sites at the same time and determine stand characteristics that could explain differences in rainfall partitioning. However, sampler based studies also showed that differences in throughfall can be driven by several crown traits (Scatena, 1990; Nadkarni and Sumera, 2004) and that the relative influence of a certain characteristic varies with season and rainfall depth (Carlyle-Moses et al., 2004; Park and Cameron, 2008).

As expected for species-rich forests, large differences were observed in amounts of stemflow reflecting the variability in crown size, leaf shape and orientation, branch angles and bark type (Crockford and Richardson, 2000; Levia and Frost, 2003). The observed differences in stemflow between the study plots were very likely an effect of beech. Although hornbeam had similar high stemflow as beech, it did not compensate for decreasing beech proportion of the study plots because hornbeam occurred in much smaller numbers.

Many authors found different and various stand characteristics to be important for rainfall partitioning in forests (sometimes even with opposite results), however, until now no 'rule' has been identified why it is sometimes one variable and sometimes another that controls interception. Although many stand characteristics seemed to play a role for rainfall partitioning in our study, the overall interception in stands of different species combinations was very similar. Stemflow and throughfall partly levelled each other out, low throughfall was compensated by higher stemflow and vice versa. Mixed stands with tree species like ash, lime, and sycamore may have characteristics that favour dripping and divert rainfall mainly to throughfall, whereas beech dominated stands transport a larger part of the water via the stems. Tree species like ash, lime, and sycamore probably have a higher storage capacity of woody elements than beech, which could cause higher interception fractions not only of the stem but also in the canopy of these species. Woody elements can have even larger storage capacities than leaves (Llorens and Gallart, 2000). 


\section{Spatial heterogeneity of throughfall along the beech to mixed forest gradient}

Throughfall heterogeneity of our study (IQR/median 4-26\% or as the coefficient of variation CV: 4-24\%) was at the lower end of the range of values summarized by Zimmermann et al. (2007) for a wide range of forest types (CV: 3-65\%). Our results are also comparable with values given by Staelens et al. (2006) for temperate hardwood forests (CV: 14-22\%). Differences however can not only appear because of forest types but also due to methodological differences.

In congruence to our results, spatial variability of throughfall was found to be higher during foliated than during leafless periods in many other studies (Reynolds and Henderson, 1967; Levia and Frost, 2006; Staelens et al., 2006; Herbst et al., 2008). This could either point out that leaves have a high influence on spatial heterogeneity of throughfall (Deguchi et al., 2006) or that the meteorological differences between summer and winter play a role. Throughfall heterogeneity decreased with increasing rainfall event amount in most studies (e.g. Levia and Frost, 2006; Staelens et al., 2006), although Ovington (1954) found the opposite. In our study, spatial distribution of throughfall was very similar between high-rainfall and low-rainfall summers. Probably, summing up throughfall over such long periods overlays the small-scale heterogeneity during individual events.

Tree species diversity did not significantly influence the spatial heterogeneity of throughfall in any of the investigated seasons. Also no other stand characteristic consistently determined throughfall heterogeneity. This is in accordance with Deguchi et al. (2006), who also found the relationship between spatial variability of throughfall and canopy structure or rainfall rate to be unclear. Shachnovich et al. (2008) suggested that the spatial heterogeneity of throughfall could rather be linked to undefined small scale structural variables in the canopy than to large scale canopy properties (e.g. canopy openness). Besides, Carlyle-Moses et al. (2004) found that the influence of stand variables could be important only for small rainfall events $(<5.0$ $\mathrm{mm}$ ) and a stand variable or combination of stand variables that had a significant effect on the spatial delivery of throughfall for one event may not have had an effect during another event.

\subsection{CONCLUSION}

We conclude that stand structural characteristics influenced rainfall partitioning and explained differences among forest stands of different tree species diversity. Several stand 
characteristics and their combinations were important. Tree species diversity expressed as Shannon index explained throughfall for different seasons most frequently. This index seemed to reflect structural differences, which may arise from different species and species composition, quite well. However, the study design did not allow a clear differentiation between diversity or species gradient effects. The importance of stand characteristics varied between seasons and years due to different rainfall conditions. Thus studies on the relationship between forest structure and rainfall partitioning are most meaningful if conducted for longer periods.

\subsection{ACKNOWLEDGEMENT}

This study was conducted in the framework of the research project 'The role of biodiversity for biogeochemical cycles and biotic interactions in temperate deciduous forests' (DFG Research Training Group 1086) funded by the German Research Foundation (DFG). We thank Jörn Gollisch for instrumentation setup and data collection during summer 2005, and the colleagues from the Research Training Group for providing us with stand structural data, especially Mascha Jacob for the LAI data. Two anonymous reviewers are gratefully acknowledged for their helpful comments.

\subsection{REFERENCES}

Anderson RC, Loucks OL, Swain AM. 1969. Herbaceous response to canopy cover, light intensity, and throughfall precipitation in coniferous forests. Ecology 50: 255-263.

André F. 2007. Influence of the heterogeneity of canopy structure on the spatio-temporal variability of atmospheric deposition within a mixed oak-beech stand. $\mathrm{PhD}$ thesis. University of Louvain. www.efor.ucl.ac.be/staff/CV/F\%20ANDRE\%20-\%20Deposition $\% 20 \mathrm{in} \% 20$ mixed\%20stand.pdf.

Augusto L, Ranger J, Binkley D, Rothe A. 2002. Impact of several common tree species of European temperate forests on soil fertility. Annals of Forest Science 59: 233-253.

Baldocchi DD. 2005. The role of biodiversity on the evaporation of forests. In: Forest diversity and function. Temperate and boreal systems. Ecological Studies, Vol. 176, Scherer-Lorenzen M, Körner C, Schulze E-D (eds); Springer: Berlin; 131-148. 
Bartelink HH, Olsthoorn AFM. 1999. Introduction: mixed forest in western Europe. In: Management of mixed-species forest: silviculture and economics. IBN Scientific Contributions, Vol. 15, Olsthoorn AFM, Bartelink HH, Gardiner JJ, Pretzsch H, Hekhuis HJ, Franc A (eds); DLO Institute for Forestry and Nature Reseach: Wageningen; 9-16.

Bates BC, Kundzewicz ZW, Wu S, Palutikof JP (eds). 2008. Climate change and water. Technical paper of the Intergovernmental Panel on Climate Change, IPCC Secretariat: Geneva. www.ipcc.ch/ipccreports/tp-climate-change-water.htm.

BMVEL (Bundesministerium für Verbraucherschutz, Ernährung und Landwirtschaft) (ed.). 2001. Gesamtwaldbericht der Bundesregierung. BMVEL: Bonn. www.bmelv.de/cln_044/ nn_751650/SharedDocs/downloads/06-Forstwirtschaft/Gesamtwaldbericht2001, templateId=raw,property=publicationFile.pdf/Gesamtwaldbericht2001.pdf.

Calder IR. 1996. Dependence of rainfall interception on drop size: 1. Development of the twolayer stochastic model. Journal of Hydrology 185: 363-378.

Carlyle-Moses DE, Flores Laureano JJ, Price AG. 2004. Throughfall and throughfall spatial variability in Madrean oak forest communities of northeastern Mexico. Journal of Hydrology 297: 124-135.

Chang S-C, Matzner E. 2000. The effect of beech stemflow on spatial patterns of soil solution chemistry and seepage fluxes in a mixed beech/oak stand. Hydrological Processes 14: $135-144$.

Chatterjee S, Price B. 1991. Regression analysis by example. John Wiley and Sons: New York.

Cionco RW. 1972. Intensity of turbulence within canopies with simple and complex roughness elements. Boundary-Layer Meteorology 2: 453-465.

Crockford RH, Richardson DP. 2000. Partitioning of rainfall into throughfall, stemflow and interception: effect of forest type, ground cover and climate. Hydrological Processes 14: 2903-2920.

Dalsgaard L. 2007. Above and below ground gaps - the effects of a small canopy opening on throughfall, soil moisture and tree transpiration in Suserup Skov, Denmark. Ecological Bulletins 52: 81-102.

Dalsgaard L. 2008. Transpiration and water budgets of European beech (Fagus sylvatica L.) dominated stands in relation to canopy structure. $\mathrm{PhD}$ thesis. University of Copenhagen. Forest and Landscape Research, Vol. 39, Forest and Landscape Denmark: Frederiksberg. http://en.sl.life.ku.dk/upload/flr39.pdf. Last visited: 15.08.2008. 
Deguchi A, Hattori S, Park H-T. 2006. The influence of seasonal changes in canopy structure on interception loss: Application of the revised Gash model. Journal of Hydrology 318: 80-102.

DWD (Deutscher Wetterdienst). http://www.dwd.de. Last visited: 15.08.2008.

Einsele G, Arnold W, Klee O, Agerer R, Agster G, Babel U, Behringer J, Böcking W, Evers F-H, Fleck W, Günzl H, Hofmann K-F, Janz H, Körner J, Kottke I, Kracht V, Krebs A, Kunzweiler K, Langbein W-D, Moosmauer H-U, Müller S, Nickel E, Pfeiffer S, Rausch R, Schmidt-Witte H, Schwarz O, Stegmayer R. 1983. Wasserhaushalt, Stoffeintrag, Stoffaustrag und biologische Studien im Naturpark Schönbuch bei Tübingen. European Journal of Forest Research 102: 282-324.

Ellenberg H. 1996. Vegetation Mitteleuropas mit den Alpen in ökologischer, dynamischer und historischer Sicht. Ulmer: Stuttgart.

Faraway JJ. 2002. Practical regression and Anova using R. http://cran.r-project.org/doc/ contrib/Faraway-PRA.pdf.

Forgeard F, Gloaguen JC, Touffet J. 1980. Interception des précipitations et apport au sol d'éléments minéraux par les eaux de pluie et les pluviolessivats dans une hêtraie atlantique et dans quelques peuplements résineaux en Bretagne. (Interception of precipitation and mineral supply to the soil by rainfall and leaching in an atlantic beech forest and in some coniferous stands in Brittany (France)). Annales des Sciences Forestières 37: 53-71.

Frech A, Leuschner C, Hagemeier M, Hölscher D. 2003. Nachbarschaftsbezogene Analyse der Kronenraumbesetzung von Esche, Hainbuche und Winterlinde in einem artenreichen Laubmischwald (Nationalpark Hainich, Thüringen). (Neighbor-dependent canopy dimensions of ash, hornbeam, and lime in a species-rich mixed forest (Hainich Nationalpark, Thuringia)). Forstwissenschaftliches Centralblatt 122: 22-35.

Groisman, P. Legates, D.R. 1994. The accuracy of United States precipitation data. Bulletin of the American Meteorological Society 75: 215-227.

Guckland A, Jacob M, Flessa H, Thomas FM, Leuschner C. 2009. Acidity, nutrient stocks and organic matter content in soils of a temperate deciduous forest with different abundance of European beech (Fagus sylvatica L.). Journal of Plant Nutrition and Soil Science 172: 500-511.

Hector A, Schmid A, Beierkuhnlein C, Caldeira MC, Diemer M, Dimitrakopoulos PG, Finn JA, Freitas H, Giller PS, Good J, Harris R, Högberg P, Huss-Danell K, Joshi J, Jumpponen A, Körner C, Leadley PW, Loreau M, Minns A, Mulder CPH, O’Donovan G, 
Otway SJ, Pereira JS, Prinz A, Read DJ, Scherer-Lorenzen M, Schulze ED, Siamantziouras A-SD, Spehn E, Terry AC, Troumbis AY, Woodward FI, Yachi S, Lawton JH. 2000. Response. Science 289: 1255a.

Herbst M, Rosier PTW, McNeil DD, Harding RJ, Gowing DJ. 2008. Seasonal variability of interception evaporation from the canopy of a mixed deciduous forest. Agricultural and Forest Meteorology 148: 1655-1667.

Heuveldop J. 1973. Die Größe der Interzeptionsverdunstung in Fichtenkronen abhängig von einzelnen klimatischen Faktoren. Allgemeine Forst- und Jagdzeitung 144: 35-41.

Horton RE. 1919. Rainfall interception. Monthly Weather Review 47: 608-623.

INRA (L'Institut National de Recherche Agronomique: French National Institute for Agricultural Research). 2007. www.avignon.inra.fr/can_eye/.

Kelliher FM, Leuning R, Schulze E-D. 1993. Evaporation and canopy characteristics of coniferous forests and grasslands. Oecologica 95: 153-163.

Kelty MJ. 1992. Comparative productivity of monocultures and mixed-species stands. In: The ecology and silviculture of mixed-species forests. A Festschrift for David M Smith. Kelty MJ, Larson BC, Oliver CD (eds); Kluwer: Dordrecht; 125-141.

Körner C. 2005. An introduction to the functional diversity of temperate forest trees. In: Forest diversity and function. Temperate and boreal systems. Ecological Studies, Vol. 176, Scherer-Lorenzen M, Körner C, Schulze E-D (eds); Springer: Berlin; 13-37.

Lawton JH, Naeem S, Thompson LJ, Hector A, Crawley MJ. 1998. Biodiversity and ecosystem function: getting the Ecotron experiment in its correct context. Functional Ecology 12: 848-852.

Lensing JR, Wise DH. 2007. Impact of changes in rainfall amounts predicted by climatechange models on decomposition in a deciduous forest. Applied Soil Ecology 35: 523534.

Leuschner C, Rode MW. 1999. The role of plant resources in forest succession: changes in radiation, water and nutrient fluxes, and plant productivity over a 300-yr-long chronosequence in NW-Germany. Perspectives in Plant Ecology, Evolution and Systematics 2: 103-147.

Leuschner C, Hertel D, Schmid I, Koch O, Muhs A, Hölscher D. 2004. Stand fine root biomass and fine root morphology in old-growth beech forests as a function of precipitation and soil fertility. Plant and Soil 258: 43-56. 
Leuschner C, Voß S, Foetzki A, Clases Y. 2006. Variation in leaf area index and stand leaf mass of European beech across gradients of soil acidity and precipitation. Plant Ecology 182: $247-258$.

Leuschner C, Jungkunst HF, Fleck S. 2009. Functional role of forest diversity: Pros and cons of synthetic stands and across-site comparisons in established forests. Basic and Applied Ecology 10: 1-9.

Levia DF Jr, Frost EE. 2003. A review and evaluation of stemflow literature in the hydrologic and biogeochemical cycles of forested and agricultural ecosystems. Journal of Hydrology 274: 1-29.

Levia, DF, Frost, EE 2006. Variability of throughfall volume and solute inputs in wooded ecosystems. Progress in Physical Geography 30: 605-632.

Link TE, Unsworth M, Marks D. 2004. The dynamics of rainfall interception by a seasonal temperate rainforest. Agricultural and Forest Meteorology 124: 171-191.

Llorens P, Poch R, Latron J, Gallart F. 1997. Rainfall interception by a Pinus sylvestris forest patch overgrown in a Mediterranean mountainous abandoned area. I. Monitoring design and results down to the event scale. Journal of Hydrology 199: 331-345.

Llorens P, Gallart F. 2000. A simplified method for forest water storage capacity measurements. Journal of Hydrology 240: 131-144.

Magurran AE. 2004. Measuring biological diversity. Blackwell Science: Oxford.

Menalled FD, Kelty MJ, Ewel JJ. 1998. Canopy development in tropical tree plantations: a comparison of species mixtures and monocultures. Forest Ecology and Management 104: 249-263.

Mitscherlich G. 1981. Wald, Wachstum und Umwelt. 2. Band: Waldklima und Wasserhaushalt. Sauerländer's Verlag: Frankfurt am Main.

Nadkarni NM, Sumera MM. 2004. Old-growth forest canopy structure and its relationship to throughfall interception. Forest Science 50: 290-298.

Neal C, Robson AJ, Bhardwaj CL, Conway T, Jeffery HA, Neal M, Ryland GP, Smith CJ, Walls J. 1993. Relationships between precipitation, stemflow and throughfall for a lowland beech plantation, Black Wood, Hampshire, southern England: findings on interception at a forest edge and the effects of storm damage. Journal of Hydrology 146: 221-233.

Nordén U. 1991. Acid deposition and throughfall fluxes of elements as related to tree species in deciduous forests of South Sweden. Water, Air and Soil Pollution 60: 209-230.

Ovington JD. 1954. A comparison of rainfall in different woodlands. Forestry 17(1): 41-53. 
Park A, Cameron JL. 2008. The influence of canopy traits on throughfall and stemflow in five tropical trees growing in a Panamanian plantation. Forest Ecology and Management 255: 1915-1925.

Peck AK. 2004. Hydrometeorologische und mikroklimatische Kennzeichen von Buchenwäldern. $\mathrm{PhD}$ thesis. Berichte des Meteorologischen Institutes der Universität Freiburg, Vol. 10, University of Freiburg. www.mif.uni-freiburg.de/berichte/Bericht10.pdf.

Peck A, Mayer H. 1996. Einfluss von Bestandesparametern auf die Verdunstung von Wäldern. (Influence of stand parameters on evaporation in forests). Forstwissenschaftliches Centralblatt 115: 1-9.

Pretzsch H. 1996. Strukturvielfalt als Ergebnis waldbaulichen Handelns. Allgemeine Forstund Jagdzeitung 167: 213-221.

Pretzsch H. 2005. Diversity and productivity in forests: evidence from long-term experimental plots. In: Forest diversity and function. Temperate and boreal systems. Ecological Studies, Vol. 176, Scherer-Lorenzen M, Körner C, Schulze E-D (eds); Springer: Berlin; 41-64.

R Development Core Team. 2008. R: A language and environment for statistical computing. R Foundation for Statistical Computing, Vienna, Austria. www.R-project.org.

Reynolds ERC, Henderson CS. 1967. Rainfall interception by beech, larch and Norway spruce. Forestry 40: 165-184.

Röhrig E, Bartsch N, von Lüpke B. 2006. Waldbau auf ökologischer Grundlage. Ulmer: Stuttgart.

Roloff A. 1989. Kronenentwicklung und Vitalitätsbeurteilung ausgewählter Baumarten der gemäßigten Breiten. Schriften aus der Forstlichen Fakultät der Universität Göttingen und der Niedersächsischen Forstlichen Versuchsanstalt, Vol. 93; Sauerländer's Verlag: Frankfurt am Main.

Scatena FN. 1990. Watershed scale rainfall interception on two forested watersheds in the Luquillo mountains of Puerto Rico. Journal of Hydrology 113: 89-102.

Scherer-Lorenzen M, Körner C, Schulze ED. 2005. The functional significance of forest diversity: a synthesis. In: Forest diversity and function. Temperate and boreal systems. Ecological Studies, Vol. 176, Scherer-Lorenzen M, Körner C, Schulze E-D (eds); Springer: Berlin; 377-389.

Schmidt I, Leuschner C, Mölder A, Schmidt W. 2009. Structure and composition of the seed bank in monospecific and tree species-rich temperate broad-leaved forests. Forest Ecology and Management 257: 695-702. 
Shachnovich Y, Berliner PR, Bar P. 2008. Rainfall interception and spatial distribution of throughfall in a pine forest planted in an arid zone. Journal of Hydrology 349: 168-177.

Shannon CE, Weaver W. 1949. The mathematical theory of communication. University of Illinois Press: Urbana.

Simpson EH. 1949. Measurement of diversity. Nature 163: 688.

Staelens J, De Schrijver A, Verheyen K, Verhoest NEC. 2006. Spatial variability and temporal stability of throughfall water under a dominant beech (Fagus sylvativa L.) tree in relationship to canopy cover. Journal of Hydrology 330: 651-662.

Staelens J, De Schrijver A, Verheyen K, Verhoest NEC. 2007. Rainfall partitioning into throughfall, stemflow, and interception within a single beech (Fagus sylvatica L.) canopy: influence of foliation, rain event characteristics, and meteorology. Hydrological Processes 22: $33-45$.

Weihe J. 1984. Benetzung und Interzeption von Buchen- und Fichtenbeständen in NW. IV. Die Verteilung des Regens unter Fichtenkronen. Allgemeine Forst- und Jagdzeitung 155: $241-252$.

Weihe J. 1985. Benetzung und Interzeption von Buchen- und Fichtenbeständen in NW. V. Die Verteilung des Regens unter Buchenkronen. Allgemeine Forst- und Jagdzeitung 156: $81-89$.

Zeng N, Shuttleworth JW, Gash JHC. 2000. Influence of temporal variability of rainfall on interception loss. Part I. Point analysis. Journal of Hydrology 228: 228-241.

Zimmermann A, Wilcke W, Elsenbeer H. 2007. Spatial and temporal patterns of throughfall quantity and quality in a tropical montane forest in Ecuador. Journal of Hydrology 343: $80-96$. 


\section{CHAPTER \\ 3}

Soil water dynamics along a tree diversity gradient in a deciduous forest in Central Germany

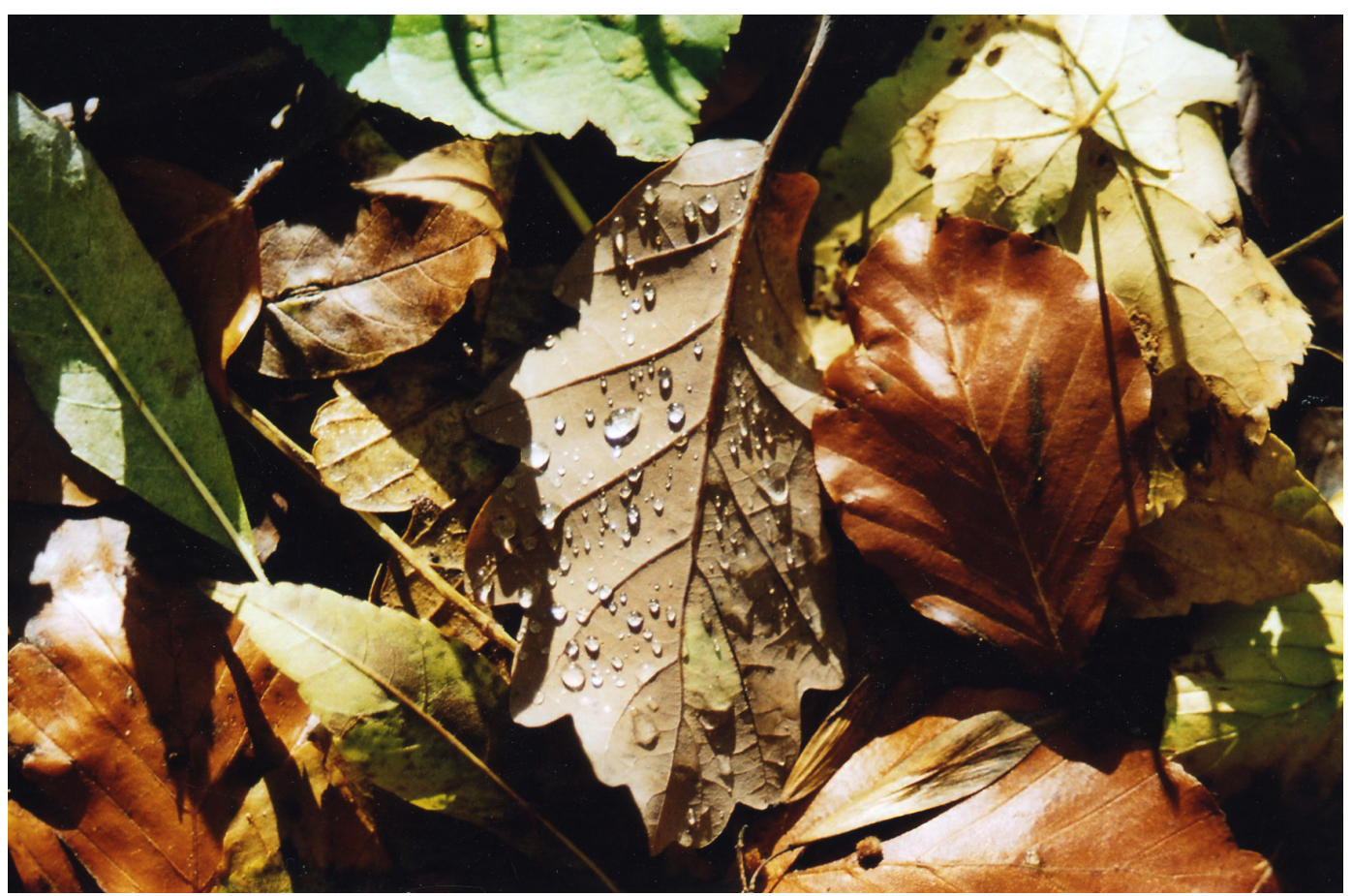




\subsection{ABSTRACT}

This study aimed to investigate whether soil water dynamics differ along a tree species diversity gradient. The twelve study plots in the Hainich National Park, Germany, were composed of up to eleven tree species. Fagus sylvatica formed the monospecific plots. Mixed forest plots consisted of a variable admixture of other broad-leaved deciduous tree species such as Tilia spec., Fraxinus excelsior, Carpinus betulus, and Acer pseudoplatanus. Volumetric soil water content and soil water potential were measured for about two and a half years. Overall patterns of soil water dynamics were similar in all study plots. However, during a desiccation period in summer 2006, significant correlations between soil water in the upper soil and tree species diversity of the twelve study plots were observed. At the beginning of this period, soil water was extracted at higher rates in the species rich plots than in the beechdominated plots. However, later during the desiccation period, when atmospheric evaporative demand was higher, only the beech-dominated stands were able to increase soil water extraction. In plots of high tree species diversity, soil water reserves were already low and soil water extraction reduced. Possible explanations for high water extraction rates in mixed species plots at the beginning of the desiccation period include species specific characteristics such as high maximum water use rate of some species, enhanced exploitation of soil water resources in mixed stands (complementarity effect), and additional water use of the herb layer, which increased along the tree species diversity gradient.

\subsection{INTRODUCTION}

Effects of biodiversity on ecosystem functioning are increasingly investigated (Hooper et al., 2005). However, most research has been carried out in grasslands and only recently forest diversity came into the focus of scientists (Scherer-Lorenzen et al., 2005 and 2007; Healy et al., 2008; Leuschner et al., 2009). Investigations on soil water relations with special regard to species diversity of the vegetation cover were almost solely restricted to grasslands until now (Caldeira et al., 2001; van Peer et al., 2004; de Boeck et al., 2006; Kreutziger, 2006; Verheyen et al., 2008). In grasslands, a more complete exploitation of available water and complementtarity in water use with increasing species diversity were suggested (van Peer et al., 2004; Verheyen et al., 2008). 
Among tree species, structural traits and physiological characteristics differ, which influences as well vertical as horizontal soil water dynamics. Next to beech (Fagus sylvatica L.), some other important deciduous broad-leaved tree species in Central European forests are smallleaved lime (Tilia cordata Mill.), large-leaved lime (T. platyphyllos Scop.), ash (Fraxinus excelsior L.), hornbeam (Carpinus betulus L.), and sycamore (Acer pseudoplatanus L.). These species have been more or less intensively studied and some of them are known for different rooting patterns (Meusel, 1951/52), different root water uptake (root sap flux density; Korn, 2004), and different transpiration rates (Hölscher et al., 2005; Gebauer, in press). Besides, the hydrological input to the soil can be influenced differently by these species. For example throughfall was found to differ among species such as beech, hornbeam, and small-leaved lime (Nordén, 1991).

Mixed forest stands may reveal characteristics which are more than the sum of tree species traits in monospecific stands. For example, tree species in mixed stands might occupy different niches in the soil. The latter was shown e.g. for rooting patterns of beech in mixture with other species (Büttner and Leuschner, 1994; Rothe and Binkley, 2001; Schmid and Kazda, 2002). Water uptake from different soil depths by co-occurring species was suggested by e.g. means of stable isotope analyses in a tropical forest (Meinzer et al., 1999) and in an agroforest (Schwendenmann et al., in press). Rainfall partitioning differed along a gradient from monospecific beech stands to species rich forest stands at the same study plots as in the present study (Krämer and Hölscher, 2009).

Regarding soil water dynamics and diversity in forests, to our knowledge only mixtures with two tree species were investigated and compared to monospecific stands. Soil water extraction was more intense and reached deeper soil layers in a mixed beech-spruce (Picea abies L.) stand, and also small-scale heterogeneity of soil water content was highest in the mixed stand (Schume et al., 2004). The overproportional evapotranspiration of the mixed beech-spruce stands was related to beech, which deepened and intensified its fine root system in the mixture whereas spruce rooted more shallowly (Schume et al., 2004). Possible diversity effects on transpiration of trees were investigated in some of the study plots where also the present study took place. In a summer with average rainfall, transpiration of a broad-leaved species rich forest stand was found to be $50 \%$ higher than transpiration of two beech-dominated stands (Gebauer, in press). However in a summer with below average rainfall amounts, transpiration was similar in all three study plots. These observations were suggested to be related to certain species effects. 
To investigate the relationship between tree species diversity and soil water dynamics, the present study was conducted simultaneously in twelve adjacent near-natural forest stands along a tree species diversity gradient from monospecific beech stands to stands composed of up to eleven tree species. The mixed forest stands consisted of a variable admixture of other broad-leaved deciduous species such as lime, ash, hornbeam, and sycamore. In Central Europe, these tree species might comprise target stands on nutrient rich soils, as mixed stands are increasingly promoted in forest management. The questions we wanted to answer were: How do soil water dynamics differ along a tree diversity gradient from monospecific beech stands to species rich forest stands, and does the spatial within-plot heterogeneity of soil water increase along this gradient?

\subsection{METHODS}

\section{Study area}

The study was conducted in the Hainich National Park in Thuringia, Central Germany. This national park was founded in 1997 and consists mainly of species rich deciduous broad-leaved forests located at the southern edge of the Hainich, a low mountain range. Before the area was declared national park, minimal forest management took place for decades due to the military training status of the area. Differences in tree species composition may be the result of former forest management in form of coppice with standards or selective cutting (Schmidt et al., 2009). Parent rock is Triassic limestone covered with a Luvisol developed from loess (Guckland et al., 2009). The climate is subatlantic and the mean annual temperature is $7.5^{\circ} \mathrm{C}$. Long term mean annual precipitation of four stations around the national park varies between 544 and $662 \mathrm{~mm}$ (DWD, 2009). In the study period, annual precipitation was $601 \mathrm{~mm}$ (2005), $518 \mathrm{~mm}$ (2006), and $838 \mathrm{~mm}$ (2007). Precipitation in the vegetation period ( $1^{\text {st }}$ May to $31^{\text {st }}$ October) was $343 \mathrm{~mm}, 282 \mathrm{~mm}$, and $549 \mathrm{~mm}$ in 2005, 2006, and 2007, respectively. While in the vegetation period of 2005 no pronounced rainless period occurred, rainfall distribution in 2006 was much more irregular with pronounced rainless periods in June, July, and September (Figure 3.1, meteomedia, Germany). In summer 2007, gross precipitation was above long-term mean and only in April and October minor rainfall amounts were observed. 


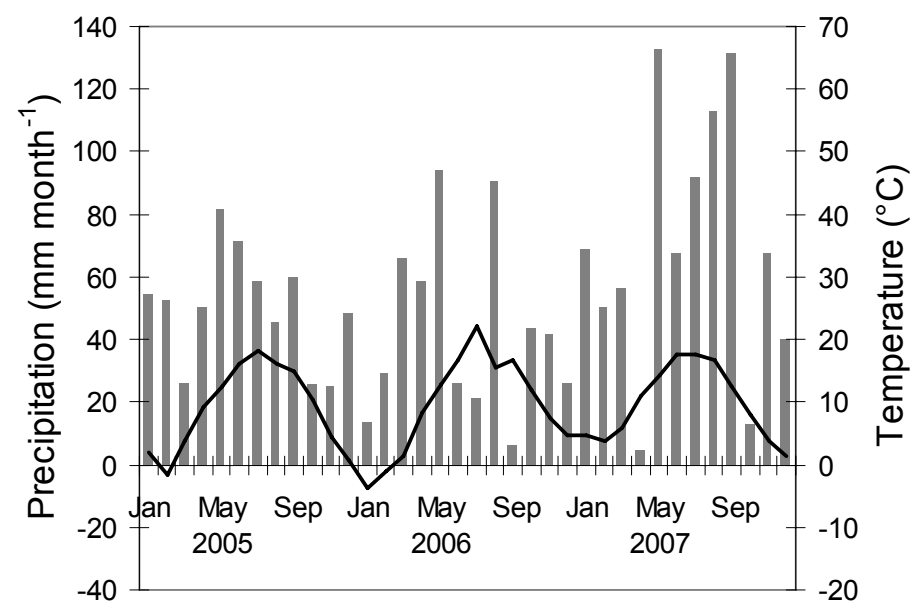

Figure 3.1 Monthly precipitation (bars) and average monthly temperature (curve) at the meteorological station close to the study plots in the Hainich National Park during the study period (data by Meteomedia, 2008).

\section{Study plots}

In the forest area, twelve study plots of each $2500 \mathrm{~m}^{2}(50 \mathrm{~m}$ x $50 \mathrm{~m})$ were selected. The plots were situated at 290-370 m a. s. 1. within a radius of $5 \mathrm{~km}$. Slopes ranged between 2 and $4^{\circ}$ and exposition of all plots was northeast. The study plots represented a gradient of tree species diversity from monospecific beech stands to mixed forest stands with a variable admixture of other broad-leaved deciduous species (Tilia cordata, T. platyphyllos, Fraxinus excelsior, Carpinus betulus, and Acer pseudoplatanus). The two Tilia species are combined as 'lime' in the analyses of this study, because it was not possible to reliably distinguish between them based on phenological traits and probably also hybrids exist. In some plots also Acer platanoides, A. campestre L., Prunus avium L., Quercus robur, Q. petraea (Matt.) Liebl., Sorbus torminalis L., and Ulmus glabra Huds. occurred but contributed little to stem number. All stand details were based on trees with a diameter at breast height $(\mathrm{dbh})>7 \mathrm{~cm}$ (Table 3.1). Shannon diversity index ( $\mathrm{H}^{\prime}$, Shannon and Weaver, 1949) can be calculated with different stand characteristics. We chose $\mathrm{H}^{\prime}$ based on the number of stems and it ranged from 0 to 1.7 among the study plots. However, $\mathrm{H}^{\prime}$ based on basal area was very similar und using it instead would not have made a difference to the outcome of this study. The share of dominating tree species was calculated by crown area. 
Table 3.1 Forest stand and site characteristics of the twelve study plots of contrasting tree species diversity in the Hainich National Park (trees $>7 \mathrm{~cm}$ dbh), 'lime': Tilia cordata and T. platyphyllos.

\begin{tabular}{|c|c|c|c|c|c|c|c|c|c|c|c|c|c|c|}
\hline \multirow[t]{2}{*}{$\begin{array}{c}\text { Study } \\
\text { plots }\end{array}$} & \multirow[t]{2}{*}{$\begin{array}{l}\text { Shannon } \\
\text { index } \\
\left(\mathrm{H}^{\prime}\right)\end{array}$} & \multicolumn{5}{|c|}{$\begin{array}{c}\text { Share of }{ }^{\mathrm{a}} \\
(\%)\end{array}$} & \multirow[t]{2}{*}{$\begin{array}{l}\text { Basal } \\
\text { area } \\
\left(\mathrm{m}^{2} \mathrm{ha}^{-1}\right)\end{array}$} & \multirow[t]{2}{*}{$\begin{array}{c}\text { Stem } \\
\text { density }^{\mathrm{a}} \\
\left(\mathrm{n} \mathrm{ha}^{-1}\right)\end{array}$} & \multirow[t]{2}{*}{$\begin{array}{l}\text { Loess } \\
\text { cover }^{\mathrm{b}} \\
(\mathrm{cm})\end{array}$} & \multicolumn{5}{|c|}{$\begin{array}{c}\text { Soil texture } \\
\text { (sand / silt / clay) } \\
(\%)\end{array}$} \\
\hline & & beech & lime & ash & $\begin{array}{l}\text { horn- } \\
\text { beam }\end{array}$ & $\begin{array}{l}\text { syca- } \\
\text { more }\end{array}$ & & & & $0-10 \mathrm{~cm}$ & $10-20 \mathrm{~cm}$ & $20-30 \mathrm{~cm}$ & $30-40 \mathrm{~cm}$ & $40-60 \mathrm{~cm}$ \\
\hline DL1a & 0.31 & 94 & 2 & 2 & 0 & 2 & 46 & 428 & 120 & $4 / 78 / 18$ & $3 / 82 / 15$ & $4 / 80 / 16$ & $4 / 78 / 18$ & $2 / 65 / 33$ \\
\hline DL1b & 0.51 & 94 & 0 & 0 & 0 & 0 & 41 & 216 & 70 & $3 / 83 / 14$ & $3 / 83 / 14$ & $4 / 82 / 14$ & $4 / 63 / 33$ & $3 / 55 / 42$ \\
\hline DL1c & 0.00 & 100 & 0 & 0 & 0 & 0 & 36 & 228 & 75 & $3 / 82 / 15$ & $2 / 83 / 15$ & $2 / 83 / 15$ & $2 / 78 / 20$ & $2 / 65 / 33$ \\
\hline DL1d & 0.51 & 94 & 0 & 0 & 0 & 4 & 44 & 224 & 80 & $3 / 73 / 24$ & $2 / 75 / 23$ & $2 / 71 / 27$ & $3 / 76 / 22$ & $3 / 73 / 24$ \\
\hline DL2a & 1.19 & 61 & 22 & 11 & 0 & 2 & 32 & 436 & 60 & $2 / 73 / 25$ & $2 / 77 / 21$ & $3 / 73 / 24$ & - & \\
\hline DL2b & 0.96 & 68 & 4 & 22 & 0 & 3 & 39 & 532 & 60 & $3 / 64 / 33$ & $2 / 68 / 30$ & $2 / 63 / 35$ & $2 / 59 / 39$ & $1 / 40 / 59$ \\
\hline DL2c & 0.84 & 73 & 14 & 10 & 0 & 1 & 45 & 776 & 120 & $2 / 78 / 20$ & $3 / 80 / 17$ & $3 / 79 / 18$ & $5 / 80 / 15$ & $2 / 57 / 41$ \\
\hline DL2d & 1.04 & 59 & 12 & 25 & 1 & 3 & 39 & 660 & 80 & $3 / 66 / 31$ & $2 / 65 / 33$ & $2 / 77 / 21$ & $3 / 75 / 22$ & $3 / 65 / 32$ \\
\hline DL3a & 1.25 & 7 & 55 & 9 & 14 & 2 & 36 & 392 & 75 & $3 / 74 / 23$ & $2 / 74 / 24$ & $2 / 74 / 24$ & $2 / 66 / 32$ & $2 / 60 / 38$ \\
\hline DL3b & 1.21 & 9 & 48 & 4 & 24 & 1 & 32 & 332 & 80 & $2 / 76 / 22$ & $3 / 75 / 22$ & $3 / 75 / 22$ & $4 / 68 / 28$ & $3 / 66 / 31$ \\
\hline DL3c & 1.30 & 48 & 18 & 19 & 6 & 8 & 41 & 468 & 60 & $2 / 66 / 32$ & $3 / 65 / 32$ & $2 / 53 / 45$ & - & - \\
\hline DL3d & 1.66 & 14 & 31 & 23 & 19 & 5 & 35 & 484 & 50 & $4 / 54 / 42$ & $4 / 59 / 37$ & $5 / 47 / 48$ & $4 / 59 / 37$ & $3 / 49 / 48$ \\
\hline
\end{tabular}

${ }^{a}$ calculated from data provided by the associated research group.

${ }^{\mathrm{b}}$ Guckland et al., 2009 (nine study plots) and A. Guckland personal communication (three additional study plots). 
Plot names follow the classification given by the research group and define a diversity level (DL1 to DL3), each level being replicated four times (a-d). Stands containing at least $80 \%$ of a single species are termed monospecific stands in this study; this is valid for the four DL1 stands. Stand age of the study plots was between around 80 and 190 years (Schmidt et al., 2009). During summer, canopy closure was on average 88\% (Krämer and Hölscher, 2009) and leaf area index (LAI) $6.7 \mathrm{~m}^{2} \mathrm{~m}^{-2}$ (Jacob et al., in press). Fine root biomass of the study plots was 440-480 $\mathrm{g} \mathrm{m}^{-2}$ in $0-40 \mathrm{~cm}$ soil depth and was not significantly correlated with $\mathrm{H}^{\prime}$; it decreased with depth (Meinen et al., 2009).

The main species of the herb layer were Anemone nemorosa L., Hordelymus europaeus (L.) Harz, Carex sylvatica Huds., Deschampsia cespitosa (L.) P. B., and Milium effusum L. In the more diverse plots (DL2 and DL3), Anemone ranunculoides L. and Ranunculus ficaria L. were found, whereas Allium ursinum L. was typical for stands of the highest diversity level DL3 (Mölder et al., 2006). Herb layer biomass was positively $\left(\mathrm{R}^{2}=0.46, \mathrm{p}=0.001\right)$ and litter layer thickness negatively $\left(\mathrm{R}^{2}=0.69, \mathrm{p}<0.001\right)$ correlated with tree species diversity (Mölder et al., 2008). In beech-dominated stands, litter from several years accumulated and formed a permanent layer of partly decomposed plant material, whereas the thin organic layer of the mixed stands consisted primarily of leaf litter from the previous year (Guckland et al., 2009).

The thickness of the loess cover was very heterogeneous even on small scales (own observation and C. Langenbruch, personal communication) and varied between 50 and $120 \mathrm{~cm}$ measured next to each study plot (soil characteristics: Guckland et al., 2009, and for data of three additional study plots A. Guckland, personal communication). Loess thickness of the study plots was not significantly correlated with $\mathrm{H}^{\prime}$. Between the limestone and the loess cover, a zone of weathered limestone debris exists. Soil texture in all study plots was characterised by high silt and low sand content (silt loam to silty clay loam, Table 3.1). Both clay $\left(0-40 \mathrm{~cm}\right.$ soil depth, $\left.\mathrm{R}^{2}=0.59, \mathrm{p}=0.004\right)$ and organic matter content $(0-30 \mathrm{~cm}$, $\left.\mathrm{R}^{2}=0.63, \mathrm{p}=0.002\right)$ increased significantly with $\mathrm{H}^{\prime}$ of the study plots. Soil bulk density increased with depth from $1.1 \mathrm{~cm}^{-3}$ at $0-10 \mathrm{~cm}$ to $1.5 \mathrm{~g} \mathrm{~cm}^{-3}$ at $40-60 \mathrm{~cm}$ soil depth (mean values); it was not significantly correlated with $\mathrm{H}^{\prime}$.

\section{Soil water measurements}

Within each of the study plots, three transects of $30 \mathrm{~m}$ length were chosen randomly (without overlapping). Each transect was equipped with two or three clusters of tensiometers to 
measure soil water potential $(\mathrm{hPa})$ and each cluster contained tensiometers at different depths. Overall, in each study plot seven tensiometers were installed at $10 \mathrm{~cm}$, another seven at $30 \mathrm{~cm}$, and four tensiometers at $50 \mathrm{~cm}$ soil depth. Along each transect, additionally two stationary PVC access tubes were installed to measure volumetric soil water content ( $\theta$ in \%) with a portable frequency domain reflectometry (FDR) probe (Diviner 2000, Sentek Pty Ltd., Stepney, Australia), resulting in six measuring points per study plot. The probe measures the dielectric constant across a $\sim 10 \mathrm{~cm}$ sphere of influence surrounding the sensor and at $10 \mathrm{~cm}$ depth intervals. Maximum length of the tubes was $70 \mathrm{~cm}$; however, the heterogeneous weathered limestone debris often started already at shallower depths and prevented the installation of access tubes to a depth of $70 \mathrm{~cm}$ in most locations. In each of the twelve study plots, six access tubes (in a few cases less, but always more than three) were in use at 10$30 \mathrm{~cm}$ soil depth. At $40 \mathrm{~cm}$ depth, still ten plots had four to six repetitions, and at $50 \mathrm{~cm}$ depth only eight study plots were used for analyses $(n \geq 4)$. The FDR probe was depth-specifically calibrated in the field as suggested and described by the manufacturer (Table 3.2).

Table 3.2 Calibration equations and coefficients of determination used to calculate volumetric water content $(\theta)$ from the scaled frequency (SF) measured with a Diviner 2000 at different soil depths.

\begin{tabular}{cccc}
\hline $\begin{array}{c}\text { Soil depth } \\
(\mathrm{cm})\end{array}$ & Calibration equation & $\mathrm{R}_{\text {adj }}^{2}$ & $\mathrm{p}$ \\
\hline 10 & $\mathrm{SF}=0.1317 \theta^{0.5227}$ & 0.99 & $<0.001$ \\
20 & $\mathrm{SF}=0.2582 \theta^{0.3532}$ & 0.91 & $<0.001$ \\
30 & $\mathrm{SF}=0.2696 \theta^{0.3595}$ & 0.98 & $<0.001$ \\
40 & $\mathrm{SF}=0.2716 \theta^{0.3560}$ & 0.96 & $<0.001$ \\
50 & $\mathrm{SF}=0.4082 \theta^{0.2486}$ & 0.87 & $<0.001$ \\
60 & $\mathrm{SF}=0.4568 \theta^{0.2179}$ & 0.84 & $<0.001$ \\
\hline
\end{tabular}

Soil water storage $(\mathrm{mm})$ at a certain depth and changes thereof at a given time interval (soil water extraction rate) were calculated from volumetric soil water measurements. The FDR probe reports volumetric soil water content as percentage $\left(\mathrm{m}^{3}\right.$ water $/ \mathrm{m}^{3}$ soil $)$ for a certain depth which is equivalent to $\mathrm{mm}$ of water within a $10 \mathrm{~cm}$ layer (e.g. a sensor at $10 \mathrm{~cm}$ soil depth gives water storage in $\mathrm{mm}$ for $5-15 \mathrm{~cm}$ depth). Water storage in $0-5 \mathrm{~cm}$ soil depth was assumed to be the same as in $5-15 \mathrm{~cm}$. We are aware that this gives only limited information for that layer, but it was the best assumption possible. Comparison with directly assessed soil 
water content in 0-5 cm depth close to some of the measuring points and at similar dates (A. Guckland, unpublished data; weighing of soil samples in the field and after drying in the oven) showed very good congruence with our data. Soil water storage of the profiles was calculated for $0-45 \mathrm{~cm}$ depth where ten study plots had sufficient repetitions $(\mathrm{n} \geq 4)$ and most of the total fine root biomass is supposed to occur (Meinen et al., 2009a). The heterogeneous thickness of the loess cover and the very stony transition zone to the limestone made a comparison of larger depths difficult. However, soil water storage was estimated for the whole profile using the loess cover thickness given for the study plots by Guckland et al. (2009). For this purpose, soil water content of the deepest measuring point of the access tubes was extrapolated to the soil below. No corrections for stone content were possible, because it was too variable. This could have led to errors at larger depths.

Measurements were carried out manually about every second week from May 2005 to August 2007 (tensiometer) and from August 2005 to December 2008 (FDR). Sometimes measurements were distributed over two successive days, but only when no rain occurred in between. The application of tensiometers was restricted due to too dry soil conditions in summer months and frost in winter. Therefore, continuous series of measurements were based on the FDR data only. During the study period, three study plots (DL1c, DL3a, and DL1d only marginal) were affected by wind throw. However, since all FDR measuring locations close to the gap did not show any apparent change after wind throw, no FDR-measuring points were removed from the analyses. Some tensiometer clusters had to be removed though (DL1c: 1, DL1d: 1, DL3a: 3).

\section{Data and statistical analyses}

To characterise measured data at the plot level, we used plot median values to reduce the influence of outliers. Spatial within-plot heterogeneity of volumetric soil water content in each study plot was expressed as the median absolute deviation/median ratio (MAD/M) (Zimmermann et al., 2007). The relation between soil water characteristics (volumetric soil water content and its within-plot heterogeneity, soil water potential, soil water storage) and tree species diversity (represented by the Shannon index, $\mathrm{H}^{\prime}$ ) was analysed using linear regressions. Additionally, species proportions and soil texture (represented by clay content) were tested. We chose clay content as the variable representing soil texture characteristics of the study plots because sand content was negligible, and clay, silt, and organic matter content were closely correlated. Since volumetric water content and soil water potential were 
measured at 10 and $20 \mathrm{~cm}$ depth intervals respectively (starting at $10 \mathrm{~cm}$ ), an average value of clay content between the above (e.g. 0-10 cm) and below (e.g. 10-20 cm) layer was used for statistical analyses. Regression analyses were only carried out when data from more than seven study plots were available for a given date. Level of significance was $p \leq 0.05$. The statistical analysis was conducted with R version 2.8.1 (R Development Core Team, 2008).

\subsection{RESULTS}

\section{Temporal variations of soil water dynamics}

Volumetric soil water content in all study plots and at all depths showed the same seasonal pattern over the course of years (Figure 3.2). Even volumetric soil water content at 50 to $70 \mathrm{~cm}$ depth had this pattern (data not shown). Differences among the study plots became larger with increasing soil depth (Figure 3.2). We observed very different summer periods. Over a 60-day period in summer 2006, volumetric soil water content decreased continuously from very high values (field capacity) at the beginning of June to minimum values of the entire study period at the end of July (referred to as 'desiccation period' from now on). In contrast, the vegetation period 2007 was characterised by high rainfall amounts and volumetric soil water content did not decrease substantially. In 2005 and 2006, volumetric soil water content started to increase rapidly in the second half of October at 10-30 cm depth. With increasing depth, this refilling started later, but at the latest after mid-December. From January to May, volumetric soil water content reached its maximum.

Spatial within-plot heterogeneity of volumetric soil water content at the study plots, expressed as the median absolute deviation/median ratio (MAD/M), was always highest from July to November (10 and $20 \mathrm{~cm}$ depth; Figure 3.3). Similar values and seasonal patterns were observed also at larger soil depths $(30-70 \mathrm{~cm}$, data not shown). 

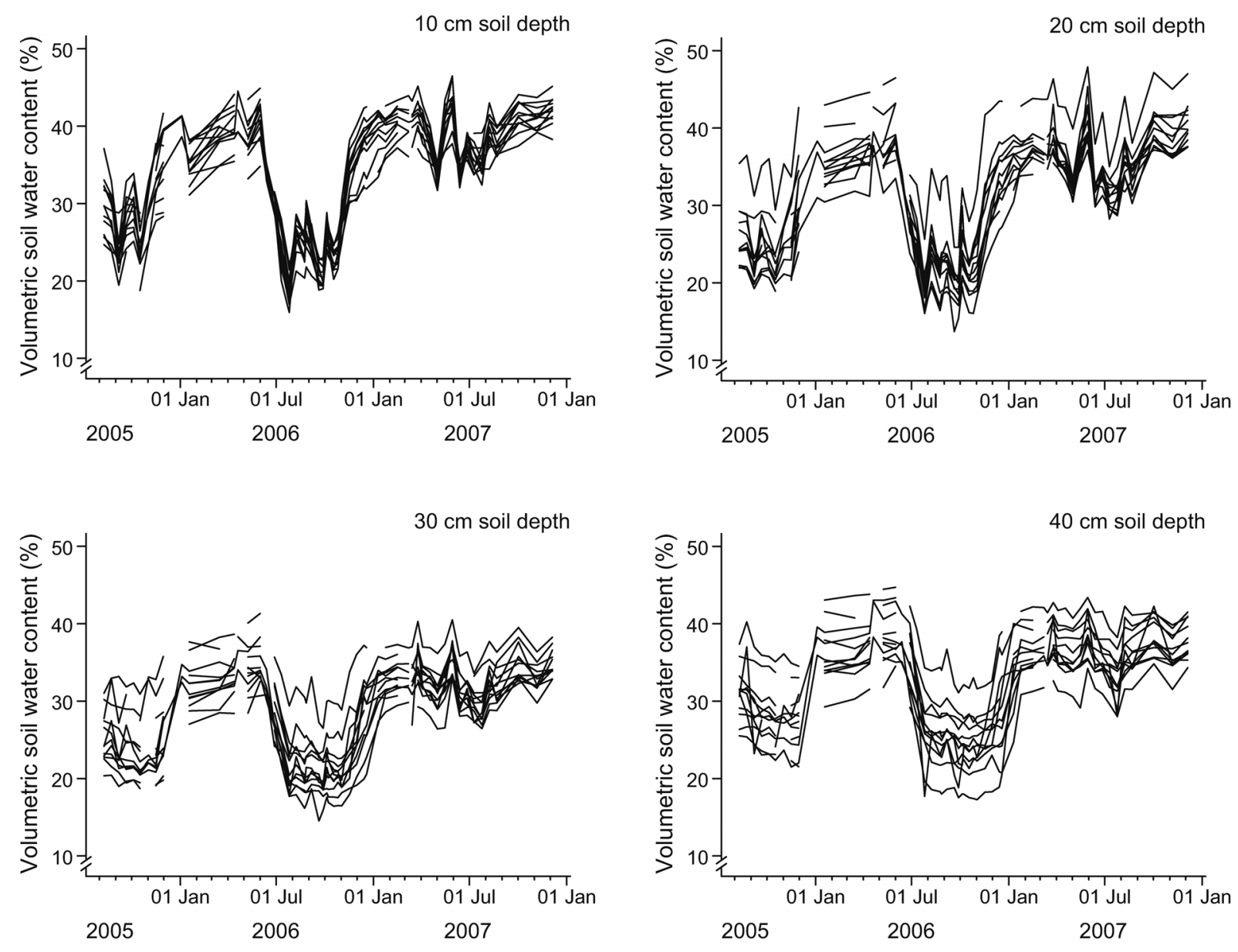

Figure 3.2 Volumetric soil water content at 10,20,30, and $40 \mathrm{~cm}$ soil depth in the twelve study plots in the Hainich National Park during the study period (August 2005-December 2007) at about twoweek intervals; plot medians (six measuring points per study plot, exceptionally four or five).
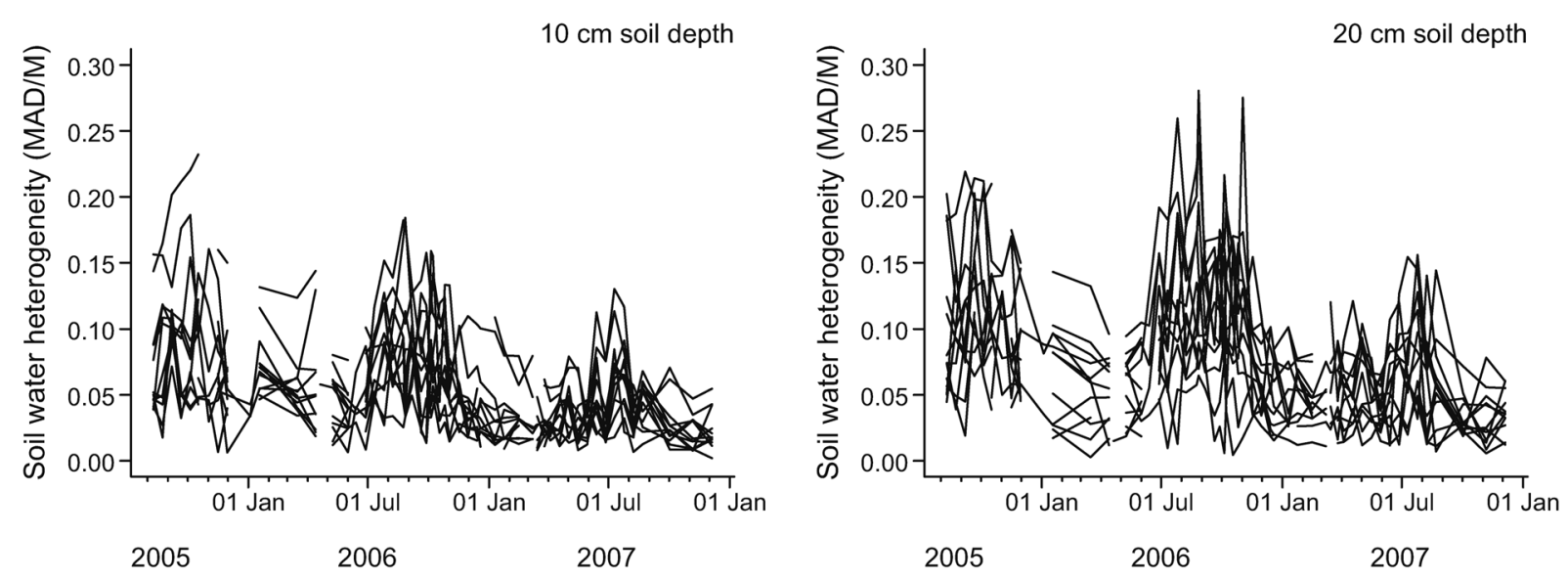

Figure 3.3 Spatial within-plot heterogeneity, as expressed by the median absolute deviation to median ratio (MAD/M) of volumetric soil water content at 10 and $20 \mathrm{~cm}$ soil depth in the twelve study plots during the study period (August 2005-December 2007) at about 2-week intervals (six measuring points per study plot, exceptionally four or five). 


\section{Differences in soil water dynamics along the tree species diversity gradient (regression analyses)}

The relationship between soil water (soil water potential and volumetric soil water content) and tree species diversity (represented by the Shannon index, $\mathrm{H}^{\prime}$ ) as well as soil texture (represented by clay content) varied over soil depth and time. The same was true for the relationship between within-plot heterogeneity of volumetric soil water content and tree species diversity as well as clay content.

Significant correlations between soil water (soil water potential and volumetric soil water content) and tree species diversity were observed in the desiccation period in summer 2006. On $9^{\text {th }}$ May, volumetric soil water content was high and increased significantly at $10 \mathrm{~cm}$ depth along the tree species diversity gradient (Figure 3.4). On $18^{\text {th }}$ May 2006, soil water potential at $10 \mathrm{~cm}$ depth $(-82$ to $-314 \mathrm{hPa})$ showed a first reduction for a short period and decreased with increasing $\mathrm{H}^{\prime}$ of the study plots (Figure 3.5). After a short rewetting phase ( $1^{\text {st }}$ June 2006 : 0 to $-25 \mathrm{hPa}$ at $10 \mathrm{~cm}$ ), this relation changed during the following desiccation period and soil water potential and volumetric soil water content of the study plots decreased with increasing $\mathrm{H}^{\prime}$ on $28^{\text {th }}$ June 2006 . At this date, median soil water potential at $10 \mathrm{~cm}$ depth ranged from $128 \mathrm{hPa}$ at the monospecific beech plot $\left(\mathrm{H}^{\prime}: 0\right)$ to $-344 \mathrm{hPa}$ at the plot with highest tree species diversity $\left(\mathrm{H}^{\prime}: 1.7\right)$. Also on $11^{\text {th }}$ and $26^{\text {th }}$ July 2006 , volumetric soil water content decreased significantly with increasing $\mathrm{H}^{\prime}$. In July 2006, soil water potential was too low for tensiometer use. At all these dates, soil water potential was not significantly correlated with clay content of the study plots. Also volumetric water content in the upper soil $(10 \mathrm{~cm})$ of the study plots was constantly better explained by $\mathrm{H}^{\prime}$ than by clay content during this period. The proportion of the single tree species was also tested as an explanatory variable, but gave less significant results.

Calculated soil water extraction rate (mm per month) indicated that the difference among the study plots appeared in June 2006, namely at 0-25 cm soil depth (Figure 3.6A). Forest stands with high tree species diversity extracted considerably more soil water than beech-dominated stands in this month. Water extraction at $0-25 \mathrm{~cm}$ soil depth was explained better by tree species diversity $\left(\mathrm{R}^{2}=0.73, \mathrm{p}<0.001\right)$ than by proportion of beech $\left(\mathrm{R}^{2}=0.56, \mathrm{p}=0.005\right)$, ash $\left(\mathrm{R}^{2}=0.46, \mathrm{p}=0.016\right)$, lime $\left(\mathrm{R}^{2}=0.39, \mathrm{p}=0.030\right)$ or hornbeam and sycamore (not significant). Also clay content gained less significant results $\left(R^{2}=0.49, p=0.011\right)$. 


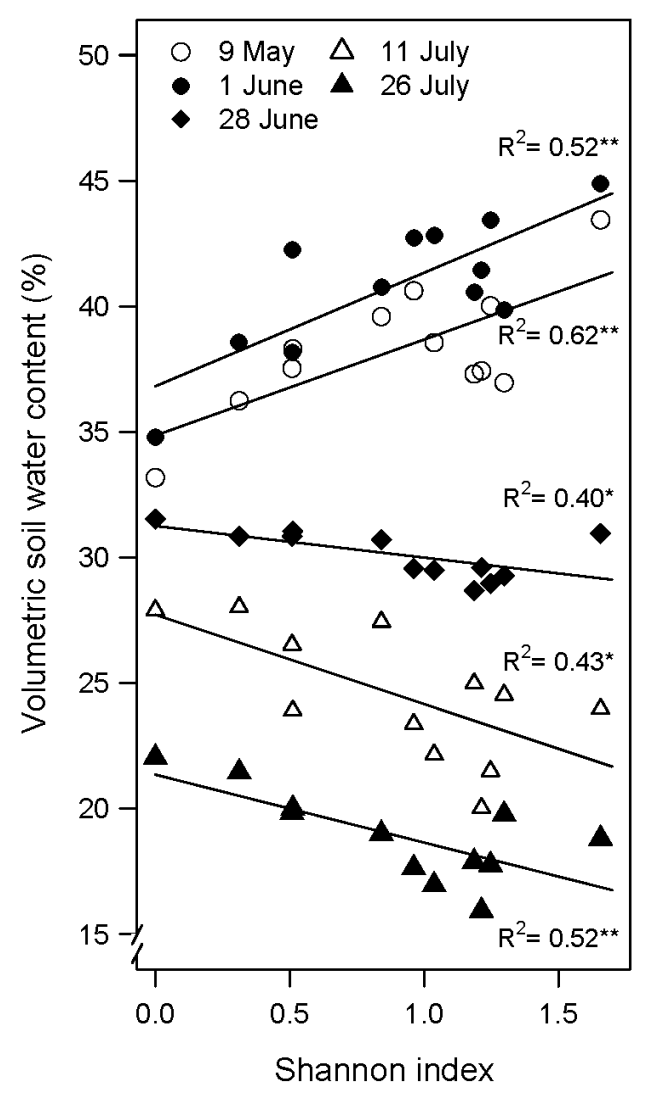

Figure 3.4 Volumetric soil water content at $10 \mathrm{~cm}$ depth in the twelve study plots in relation to Shannon diversity index from mid May to the end of July 2006; plot medians (six measuring points per study plot, exceptionally four or five; $* \mathrm{p} \leq 0.05, * * \mathrm{p} \leq 0.01$ ).

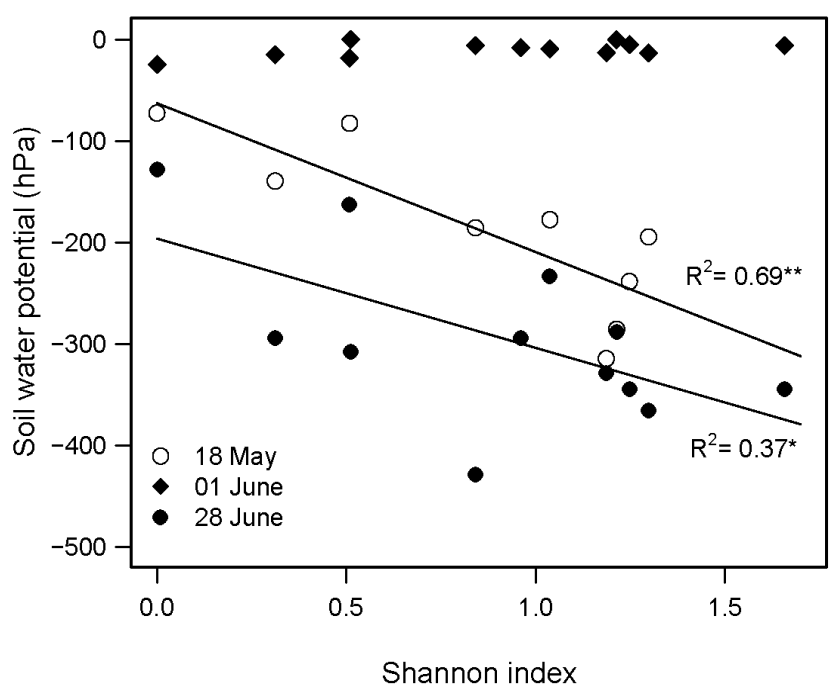

Figure 3.5 Soil water potential at $10 \mathrm{~cm}$ depth in the twelve study plots in relation to Shannon diversity index in May and June 2006; plot medians (seven measuring points per study plot, exceptionally four, five, or six; $* \mathrm{p} \leq 0.05,{ }^{* *} \mathrm{p} \leq 0.01$ ). 

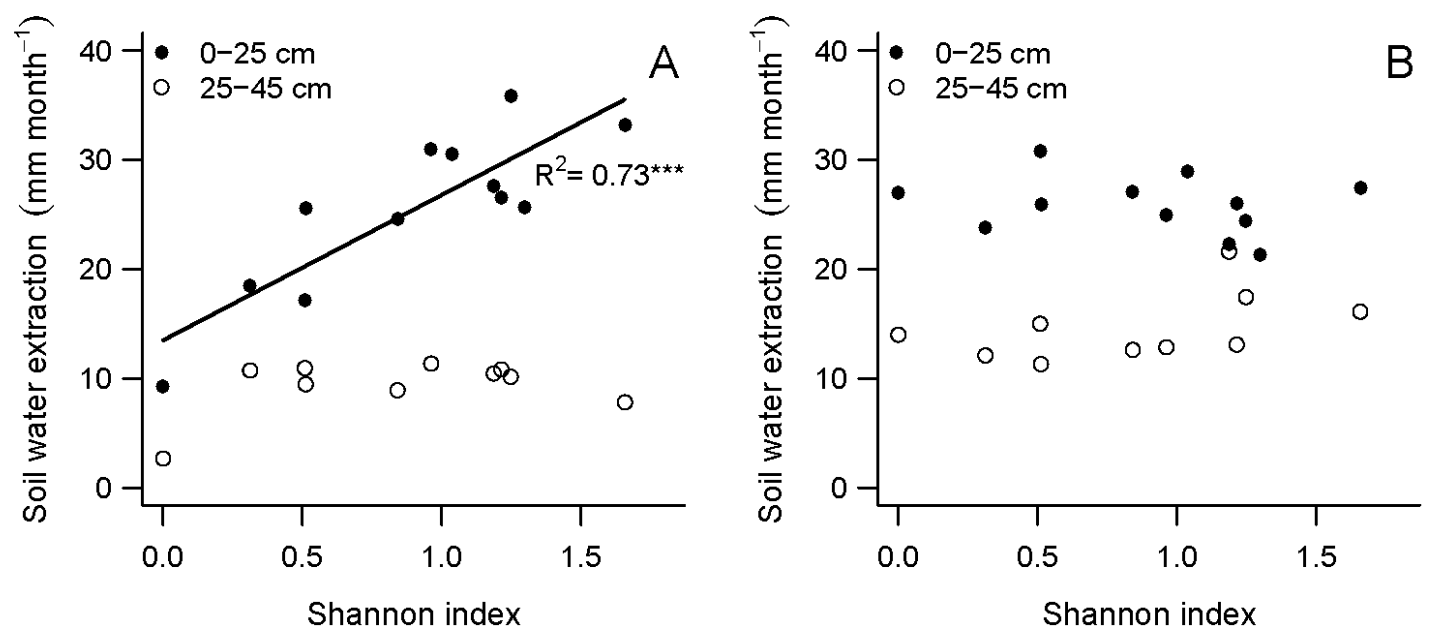

Figure 3.6 Soil water extraction in the 12 study plots in relation to Shannon diversity index in June (A) and July (B) $2006(* * * \mathrm{p} \leq 0.001)$.

In July 2006, extracted soil water was about the same among the study plots and on average $26 \mathrm{~mm}$ at $0-25 \mathrm{~cm}$ soil depth and $15 \mathrm{~mm}$ at $25-45 \mathrm{~cm}$ soil depth (Figure 3.6B). Soil water extraction in the beech-dominated study plots increased in comparison to June. However at the same time, a decrease of soil water extraction in the species rich study plots was observed. At field capacity on $1^{\text {st }}$ June 2006, water storage of the upper $45 \mathrm{~cm}$ of the soil profile varied between 155 and $203 \mathrm{~mm}$ among the study plots and increased with $\mathrm{H}^{\prime}\left(\mathrm{R}^{2}=0.58, \mathrm{p}=0.010\right)$. However, estimated for the whole profile, water storage of the study plots at field capacity was very variable $(240-457 \mathrm{~mm})$ and no significant correlation with $\mathrm{H}^{\prime}$ was observed. On $27^{\text {th }}$ July 2006, under very dry soil conditions, $81-115 \mathrm{~mm}$ water was left in $0-45 \mathrm{~cm}$ of the study plots (whole profile: 117-364 mm) and water storage of the study plots did not correlate with $\mathrm{H}^{\prime}$. The difference between maximum and minimum water storage of the study plots at 0-45 cm depth was thereby 54-94 mm, increasing with $\mathrm{H}^{\prime}\left(\mathrm{R}^{2}=0.68, \mathrm{p}=0.003\right)$, and 85$179 \mathrm{~mm}$ estimated for the whole profile, which did not correlate significantly with $\mathrm{H}^{\prime}$. 


\subsection{DISCUSSION}

\section{Temporal variations of soil water dynamics}

In general, all twelve study plots showed similar temporal and spatial (both vertical and horizontal) patterns in soil water dynamics. Temporal variation of volumetric soil water content observed at soil depths down to $70 \mathrm{~cm}$ suggested that also deep roots extracted water in our study plots. This is supported by findings in another beech-dominated stand on heterogeneous loess cover with limestone debris. Maximum extracted water in the upper soil of that stand (Gerke, 1987) was comparable to our data. The beech stand extracted substantial amounts of water at the transition zone to the limestone debris and even from gaps between the limestone down to $4 \mathrm{~m}$ depth in a relatively dry summer (Gerke, 1987). Some tree species such as beech and oak can have another peak in root density at large soil depths (Bouten et al., 1992; Vincke and Delvaux, 2005), where the roots ramify to make use of the water present there (Meusel, 1951/1952). However, there are no data on root distribution deeper than $40 \mathrm{~cm}$ in our study plots, but from own observations we know of considerable root abundance also at larger dephts.

The high within-plot heterogeneity of volumetric soil water content in the study plots during dry soil conditions in summer and autumn might be both an effect of heterogeneous soil water uptake and throughfall (Krämer and Hölscher, 2009). Additionally, the relatively high clay content of the study plots led to soil cracks during dry soil conditions, which also could contribute to high spatial heterogeneity of soil water content.

\section{Differences in soil water dynamics along the tree species diversity gradient}

Regarding the whole measuring period of two and a half years, no variable could be identified that consistently explained the differences in soil water dynamics among the study plots. Also other authors (Familglietti et al., 1998; Western et al., 1999; Qiu et al., 2001; Cantón et al., 2004) concluded that it is difficult to identify single factors (such as soil texture and vegetation cover) affecting soil water content because of their complex influence. It has to be noted that as well single species proportions as certain site characteristics (clay, organic matter content) correlate well with the investigated diversity gradient of this study (so called 'hidden treatments'). Obviously, several site and stand characteristics act together and only in certain periods one is dominating. Such a consistent dominance was observed in a 60 day long desiccation period in summer 2006, when differences in soil water (soil water potential, 
volumetric soil water content, and soil water storage) in the upper soil layer were best explained by tree species diversity of the study plots (expressed as Shannon index $\mathrm{H}^{\prime}$ ). This observation will be discussed more detailed in the next section. No consistent explanations for the differences in soil water among the study plots were found for larger soil depths. This is probably related to increasing soil heterogeneity and stone content with depth, which also led to larger differences in volumetric soil water content among the study plots with increasing soil depth.

Neither tree species diversity nor clay content of the study plots could explain differences in the spatial within-plot heterogeneity $(\mathrm{MAD} / \mathrm{M})$ of volumetric soil water content among the study plots consistently. Also small-scale throughfall heterogeneity of the investigated study plots could not be explained by tree species diversity or any other stand characteristic (Krämer and Hölscher, 2009). It is likely that within-plot heterogeneity of soil water is influenced by small-scale heterogeneity of soil properties and vegetation distribution, which could not be included in the analysis.

\section{Possible diversity effect in the desiccation period in summer 2006}

The observed decrease of soil water (soil water potential, volumetric soil water content, and soil water storage) with increasing tree species diversity of the study plots was caused either by hydrological in- or output. Neither throughfall nor interception showed a directed effect along the investigated tree species diversity gradient in summer 2006 (Krämer and Hölscher, 2009). Almost no rain occurred in June and July 2006 and throughfall on the study plots was on average 15 and $8 \mathrm{~mm}$, respectively (I Krämer, unpublished data). Although stemflow decreased significantly with $\mathrm{H}^{\prime}$ (respectively increased with beech proportion) of the study plots, it was only a minor part of gross precipitation in summer $2006(0.4-1.6 \%$; Krämer and Hölscher, 2009). Locations of soil water measurements were not in proximity to stems. Stemflow is assumed to enter the soil directly next to the stem following the coarse roots into the soil (Voigt, 1960).

In addition to tree canopy interception also the herb (inclusive shrub) layer and the litter layer intercepts rainfall water i.e. throughfall (so called 'secondary interception'). In beech forests, litter layer interception was found to account for 34\% (Gerrits et al., 2006) and 15-32\% (Fleck, 1987) of throughfall. Apart from Schnock (1970, as cited in Vincke et al., 2005b) who estimated the herb layer interception in several deciduous forests to account for $1-12 \%$ of gross precipitation, we are not aware of any other study analysing interception rates of the 
herb layer in forests similar to ours. As the herb layer biomass increased and the litter layer thickness decreased along the investigated gradient (Mölder et al., 2008), the secondary interception could be assumed to be similar in all study plots during summer. Both herb and litter layer prevent evaporation from the soil surface.

As also drainage was unlikely to occur in the focused desiccation period, water uptake of the vegetation is considered to be the reason for the observed differences. Tree transpiration at the stand level was estimated from xylem sap flux measurements (Gebauer, in press) for three of the twelve study plots investigated in the present study. Indeed, one of the more diverse study plots (DL3a) had higher transpiration than one monospecific beech stand (DL1a) in June, which supports our findings of soil water extraction in this month. The third study plot with an intermediate $\mathrm{H}^{\prime}$ (DL2c) also had intermediate transpiration. The course of tree transpiration in July showed a transpiration increase of the monospecific beech stand as well as a decrease at the plot with the highest tree species diversity (Gebauer, in press). Also this is in agreement with our findings (Figure 3.6B). The increase in transpiration of the monospecific beech stand can be explained by the higher atmospheric evaporative demand in July (T. Gebauer, personal communication), whereas the mixed stand was obviously limited by low soil water availability in this month.

As soil water extraction may yield a good estimate of stand transpiration for periods without precipitation, we are able to make a comparison for July 2006 when almost no precipitation occurred. Drainage (due to desiccation of the soil) and evaporation (due to intense soil cover) were assumed to be neglectable or at least very low. In this month, extracted soil water (at 0$45 \mathrm{~cm}$ soil depth) in the monospecific beech plot (DL1a) equalled transpiration of the trees (Figure 3.7, transpiration data by T. Gebauer, personal communication). However, in the two mixed study plots, extracted soil water was higher than transpiration of the trees. The same effect was also observed in June (data not shown). The difference was largest at the study plot with highest tree species diversity (DL3a). If no unknown systematic error of the applied methods was responsible for this, the extra amount of water extraction could be related to water uptake by herbaceous vegetation (and tree regeneration). Both the above- (Mölder et al., 2008) and belowground biomass (Meinen et al., 2009a) of the herb layer increased along the tree species diversity gradient. To our knowledge, no study has investigated in depth herb layer transpiration in forests comparable to ours. In most studies, evapotranspiration of the herb layer was determined and not solely herb layer transpiration. The herb layer (sometimes the whole understorey was investigated) can use considerable amounts of water for (evapo-) transpiration in addition to the tree layer as shown for different forest types (Johnson and 
Kovner, 1956; Zahner, 1958; Leuschner, 1986; Lüttschwager et al., 1999; Vincke et al., 2005a, b; Iida et al., 2009; Müller and Bolte, 2009). Especially in dry periods, the herb layer can compete for water with the tree layer (Ellenberg, 1996; Müller et al., 1998). Herb layer transpiration of about $20 \%$ of the tree layer would already explain the observed differences in water extraction among our study plots. As indicated before, the investigated stands also extracted soil water from larger depths. If this was the case and considerable amounts of water were used for transpiration by trees from larger soil depths than $0-45 \mathrm{~cm}$, transpiration was probably underestimated by the xylem flux method.

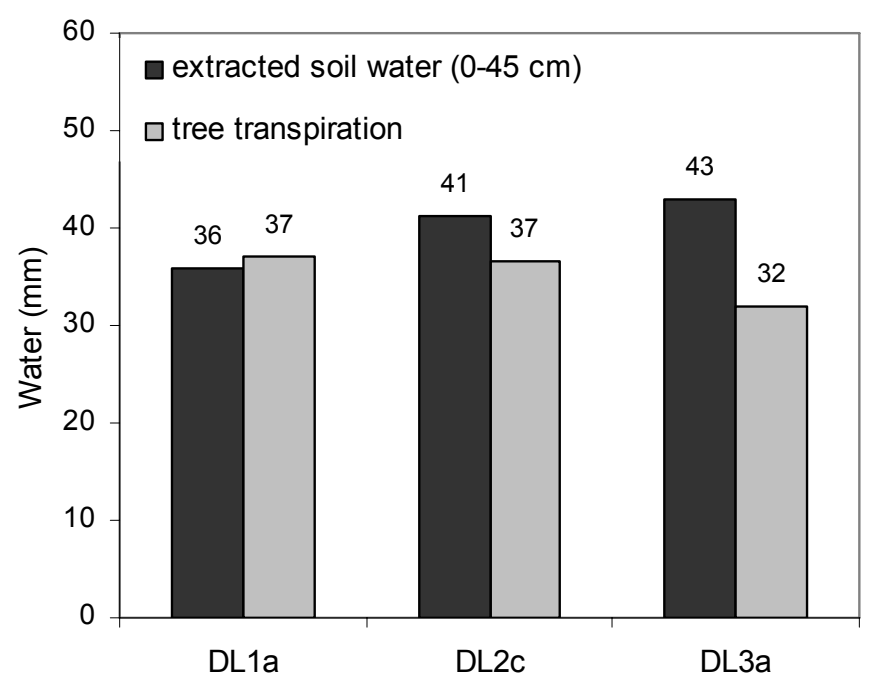

Figure 3.7 Soil water extraction and transpiration of trees (in $\mathrm{mm}$ ) in three out of twelve study plots in July 2006; different diversity levels (DL): monospecific (DL1) to high tree species diversity (DL3); transpiration data by T. Gebauer, personal communication.

The question is whether the observed differences in soil water dynamics along the tree species diversity gradient in summer 2006 were a consequence of complementary water use or a selection effect. A complementarity effect would arise from niche differentiation and/or facilitation among species, where resource partitioning or interactions lead to increased resource use; a selection effect would be related to the dominance of species with particular traits that affect ecosystem processes (Loreau and Hector, 2001). As we were not able to investigate monospecific stands of all species included, no clear separation between these two effects is possible (Loreau and Hector, 2001). However, there are several indications. Gebauer (in press) related the different transpiration rates of the investigated stands to certain species which would correspond to a selection effect. Lime, a species with high water consumption under optimal conditions, reduced soil water reserves substantially already in June. However, 
our results from the twelve study plots indicated that not only the lime-dominated stands had high water extraction rates in June 2006 but also the other mixed study plots with lime proportions of as low as $4 \%$. Water extraction of the study plots in June was explained better by tree species diversity than by proportion of lime or any other tree species. A selection effect could only be supported if also at least one other species would exert the same effect as lime. Also a complementarity effect could be considered. Even though no indications of a spatial segregation of the fine roots of the coexisting species were found down to a depth of $40 \mathrm{~cm}$ (Meinen et al., 2009b), roots exert different activity. The high correlation between water extraction and tree species diversity (the diverse plots were represented by quite different tree species composition) suggests that complementarity may have played a role. Additionally, water extraction from larger soil depths in our study plots can also not be excluded, but observed differences at these depths among the study plots probably arose from the heterogeneous limestone debris layer which covered vegetation effects. If water extraction of the herb layer in the mixed study plots indeed played an important role, this would support the complementarity effect, however not regarding forest diversity but on an ecosystem level.

Similar to our results, also other studies in forests have observed effects of species differences or diversity on soil water extraction in periods of restricted soil water availability (Leuschner, 1993; Schume et al., 2004). That species diversity seemed to have an enhancing effect on soil water extraction in a dry period, leading to limited soil water availability when this period continued, was also observed in grasslands (Hooper and Vitousek, 1998; van Peer et al., 2004; Kreutziger, 2006; Verheyen et al., 2008). This was related to e.g. complementary water use. However, the higher likelihood of including drought-tolerant species in mixed assemblages can result in continuing transpiration rates even under severe drought stress (Verheyen et al., 2008; the so called 'selection effect').

\subsection{CONCLUSION}

Extraction of water in the upper soil increased along the investigated tree species diversity gradient in a desiccation period, which led to limited soil water availability at the diverse study plots when this period continued. Possible reasons are the high water use of some tree species, complementary water use, and considerable transpiration of the herb layer in the mixed species plots. The investigated diverse tree species combination could therefore 
increase drought stress in marked desiccation periods. These effects were observed in grassland diversity studies before, but not for forest diversity yet.

\subsection{ACKNOWLEDGEMENT}

This study was conducted in the framework of the interdisciplinary research project 'The role of biodiversity for biogeochemical cycles and biotic interactions in temperate deciduous forests' (DFG Research Training Group 1086) funded by the German Research Foundation. We thank Jörn Gollisch for instrumentation setup and data collection from summer 2005 to spring 2006, the colleagues from the Research Training Group for providing us with site and stand characteristic data, and Luitgard Schwendenmann, Diego Dierick, and the reviewers for critically reading and commenting the manuscript.

\subsection{REFERENCES}

Bouten W, Schaap MG, Bakker DJ, Verstraten JM. 1992. Modelling soil water dynamics in a forested ecosystem. I: A site specific evaluation. Hydrological Processes 6: 435-444.

Büttner V, Leuschner C. 1994. Spatial and temporal patterns of fine root abundance in a mixed oak-beech forest. Forest Ecology and Management 70: 11-21.

Caldeira MC, Ryel RJ, Lawton JH, Pereira JS. 2001. Mechanisms of positive biodiversityproduction relationships: insights provided by $\delta^{13} \mathrm{C}$ analysis in experimental Mediterranean grassland plots. Ecology Letters 4: 439-443.

Cantón Y, Solé-Benet A, Domingo F. 2004. Temporal and spatial patterns of soil moisture in semiarid badlands of SE Spain. Journal of Hydrology 285: 199-214.

de Boeck HJ, Lemmens CMHM, Bossuyt H, Malchair S, Carnol M, Merckx R, Nijs I, Ceulemans R. 2006. How do climate warming and plant species richness affect water use in experimental grasslands? Plant and Soil 288: 249-261.

DWD (Deutscher Wetterdienst). http://www.dwd.de. Last visited: $24^{\text {th }}$ July 2009.

Ellenberg H. 1996. Vegetation Mitteleuropas mit den Alpen in ökologischer, dynamischer und historischer Sicht. Ulmer: Stuttgart. 1096 pp.

Famiglietti JS, Rudnicki JW, Rodell M. 1998. Variability in surface moisture content along a hillslope transect: Rattlesnake Hill, Texas. Journal of Hydrology 210: 259-281. 
Fleck, W. 1987. Einfluß des Bodenaufbaus und des Waldbestandes auf Verdunstung und Abflußbildung im Naturpark Schönbuch bei Tübingen. PhD Thesis. University of Tübingen.

Gebauer T. In press. Water turnover in species-rich and species-poor deciduous forests: xylem sap flow and canopy transpiration. PhD thesis. University of Göttingen, Göttingen. Göttingen Centre for Biodiversity and Ecology. Biodiversity and Ecology Series B4.

Gerke H. 1987. Untersuchungen zum Wasserhaushalt eines Kalkbuchenwald-Ökosystems und zur Wasserbewegung in flachgründigen Böden und im durchwurzelten Kalkgestein als Grundlage zur Modellentwicklung. Berichte des Forschungszentrums Waldökosysteme/ Waldsterben A27.

Gerrits AMJ, Savenije HHG, Hoffmann L, Pfister L. 2006. Measuring forest floor interception in a beech forest in Luxembourg. Hydrology and Earth System Sciences Discussions 3: 2323-2341.

Guckland A, Jacob M, Flessa H, Thomas FM, Leuschner C. 2009. Acidity, nutrient stocks and organic matter content in soils of a temperate deciduous forest with different abundance of European beech (Fagus sylvatica L.). Journal of Plant Nutrition and Soil Science 172: 500-511.

Healy C, Gotelli NJ, Potvin C. 2008. Partitioning the effects of biodiversity and environmental heterogeneity for productivity and mortality in a tropical tree plantation. Journal of Ecology 96: 903-913.

Hölscher D, Koch O, Korn S, Leuschner C. 2005. Sap flux of five co-occurring tree species in a temperate broad-leaved forest during seasonal soil drought. Trees 19: 628-637.

Hooper DU, Vitousek PM. 1998. Effects of plant composition and diversity on nutrient cycling. Ecological Monographs 68, 121-149.

Hooper DU, Chapin III FS, Ewel JJ, Hector A, Inchausti P, Lavorel S, Lawton JH, Lodge DM, Loreau M, Naeem S, Schmid B, Setälä H, Symstad AJ, Vandermeer J, Wardle DA. 2005. Effects of biodiversity on ecosystem functioning: a consensus of current knowledge. Ecological Monographs 75: 3-35.

Iida S, Ohta T, Matsumoto K, Nakai T, Kuwada T, Kononov AV, Maximov TC, van der Molen MK, Dolman H, Tanaka H, Yabuki H. 2009. Evapotranspiration from understory vegetation in an eastern Siberian boreal larch forest. Agricultural and Forest Meteorology 149: 1129-1139.

Jacob M, Leuschner C, Thomas FM. In press. Productivity of temperate broad-leaved forest stands differing in tree species diversity. Annals of Forest Science. 
Johnson EA, Kovner JL. 1956. Effect on streamflow of cutting a forest understory. Forest Science 2: 82-91.

Korn S. 2004. Experimentelle Untersuchung der Wasseraufnahme und der hydraulischen Eigenschaften des Wurzelsystems von sechs heimischen Baumarten. $\mathrm{PhD}$ thesis, University of Göttingen. http://webdoc.sub.gwdg.de/diss/2004/korn/korn.pdf.

Krämer I, Hölscher D. 2009. Rainfall partitioning along a tree diversity gradient in a deciduous old-growth forest in Central Germany. Ecohydrology 2: 102-114.

Kreutziger Y. 2006. Rückkopplungseffekte verschieden diverser Grünlandökosysteme auf die Komponenten des Bodenwasserhaushalts an einem Auestandort der Saale. Ergebnisse des Jenaer Biodiversitätsexperiments. $\mathrm{PhD}$ thesis. University of Jena. http://deposit.ddb.de/ cgi-bin/dokserv?idn=982774559\&dok_var=d1\&dok_ext=pdf\&filename=982774559.pdf.

Leuschner C. 1986. Niederschlags-Interzeption aus ökologischer Sicht: Mikrometeorologische und physiologische Untersuchungen in krautigen Pflanzenbeständen. Berichte des Forschungszentrums Waldökosysteme/Waldsterben A23. Leuschner C. 1993. Patterns of soil water depletion under coexisting oak and beech trees in a mixed stand. Phytocoenologia 23, 19-33.

Leuschner C, Jungkunst HF, Fleck S. 2009. Functional role of forest diversity: Pros and cons of synthetic stands and across-site comparisons in established forests. Basic and Applied Ecology 10: 1-9.

Loreau M, Hector A. 2001. Partitioning selection and complementarity in biodiversity experiments. Nature 412: 72-76.

Lüttschwager D, Rust S, Wulf M, Forkert J, Hüttl RF. 1999. Tree canopy and herb layer transpiration in three Scots pine stands with different stand structures. Annals of Forest Science 56: 265-274.

Meinen C, Hertel D, Leuschner C. 2009a. Biomass and morphology of fine roots in temperate broad-leaved forests differing in tree species diversity: is there evidence of below-ground overyielding? Oecologia 161: 99-111.

Meinen C, Leuschner C, Ryan NT, Hertel D. 2009b. No evidence of spatial root system segregation and elevated fine root biomass in multi-species temperate broad-leaved forests. Trees 23: 941-950. DOI: 10.1007/s00468-009-0336-x.

Meinzer FC, Andrade JL, Goldstein G, Holbrook NM, Cavelier J, Wright SJ. 1999. Partitioning of soil water among canopy trees in a seasonally dry tropical forest. Oecologia 121: 293-301. 
Meusel H. 1951/52. Die Eichen-Mischwälder des Mitteldeutschen Trockengebiete. Wissenschaftliche Zeitschrift der Martin-Luther-Universität Halle-Wittenberg 1: 4-72.

Mölder A, Bernhard-Römermann M, Schmidt W. 2006. Forest ecosystem research in Hainich National Park (Thuringia): First results on flora and vegetation in stands with contrasting tree species diversity. Waldökologie online 3: 83-99.

Mölder A, Bernhard-Römermann M, Schmidt W. 2008. Herb-layer diversity in deciduous forests: Raised by tree richness or beaten by beech? Forest Ecology and Management 256: $272-281$.

Müller J, Bolte A. 2009. The use of lysimeters in forest hydrology research in north-east Germany. Landbauforschung - vTI Agriculture and Forest Research 59: 1-10.

Müller J. Bolte A, Beck W, Anders S. 1998. Bodenvegetation und Wasserhaushalt von Kiefernforstökosystemen (Pinus sylvestris L.). Verhandlungen der Gesellschaft für Ökologie 28: 407-414.

Nordén U. 1991. Acid deposition and throughfall fluxes of elements as related to tree species in deciduous forests of South Sweden. Water, Air and Soil Pollution 60: 209-230.

Qiu Y, Fu B, Wang J, Chen L. 2001. Spatial variability of soil moisture content and its relation to environmental indices in a semi-arid gully catchment of the Loess Plateau, China. Journal of Arid Environments 49: 723-750.

R Development Core Team. 2008. R: A language and environment for statistical computing. R Foundation for Statistical Computing, Vienna, Austria. www.R-project.org.

Rothe A, Binkley D. 2001.Nutritional interactions in mixed species forests: a synthesis. Canadian Journal of Forest Research 31: 1855-1870.

Scherer-Lorenzen M, Körner C, Schulze E-D. 2005. The functional significance of forest diversity: a synthesis. In Forest diversity and function. Temperate and boreal Systems. Ecological Studies, Vol. 176, Scherer-Lorenzen M, Körner C, Schulze E-D (eds); Springer: Berlin; 377-389.

Scherer-Lorenzen M, Schulze E-D, Don A, Schumacher J, Weller E. 2007. Exploring the functional significance of forest diversity: A new long-term experiment with temperate tree species (BIOTREE). Perspectives in Plant Ecology, Evolution and Systematics 9: 5370 .

Schmid I, Kazda M. 2002. Root distribution of Norway spruce in monospecific and mixed stands on different soils. Forest Ecology and Management 159: 37-47. 
Schmidt I, Leuschner C, Mölder A, Schmidt W. 2009. Structure and composition of the seed bank in monospecific and tree species-rich temperate broad-leaved forests. Forest Ecology and Management 257: 695-702.

Schnock G. 1970. Le bilan d'eau et ses principales composantes dans une chênaie mélangée calcicole de haute-Belgique (bois de Virelles-Blaimont), ULB, Fac. Sci. labo. de botasystématique et d'écologie.

Schume H, Jost G, Hager H. 2004. Soil water depletion and recharge patterns in mixed and pure forest stands of European beech and Norway spruce. Journal of Hydrology 289: 258274.

Schwendenmann L, Veldkamp E, Moser G, Hölscher D, Köhler M, Clough Y, Anas I, Djajakirana G, Erasmi S, Hertel D, Leitner D, Leuschner C, Michalzik B, Propastin P, Tjoa A, Tscharntke T, van Straaten O. In press. Effects of an experimental drought on the functioning of a cacao agroforestry system, Sulawesi, Indonesia. Global Change Biology. DOI: $10.1111 /$ j.1365-2486.2009.02034.x

Shannon CE, Weaver W. 1949. The Mathematical Theory of Communication. University of Illinois Press: Urbana.

van Peer L, Nijs I, Reheul D, de Cauwer B. 2004. Species richness and susceptibility to heat and drought extremes in synthesized grassland ecosystems: compositional vs physiological effects. Functional Ecology 18: 769-778.

Verheyen K, Bulteel H, Palmborg C, Olivié B, Nijs I, Raes D, Muys B. 2008. Can complementarity in water use help to explain diversity-productivity relationships in experimental grassland plots? Oecologia 156: 351-361.

Vincke C, Breda N, Granier A, Devillez F. 2005a. Evapotranspiration of a declining Quercus robur (L.) stand from 1999 to 2001. I. Trees and forest floor daily transpiration. Annals of Forest Science 62: 503-512.

Vincke C, Breda N, Granier A, Devillez F. 2005b. Evapotranspiration of a declining Quercus robur (L.) stand from 1999 to 2001. II. Daily actual evapotranspiration and soil water reserve. Annals of Forest Science 62: 615-623.

Vincke C, Delvaux B. 2005. Porosity and available water of temporarily waterlogged soils in a Quercus robur (L.) declining stand. Plant and Soil 271: 189-203.

Voigt GK. 1960. Distribution of rainfall under forest stands. Forest Science 6: 2-10.

Western AW, Grayson RB, Blöschl G, Willgoose GR, McMahon TA. 1999. Observed spatial organization of soil moisture and its relation to terrain indices. Water Resources Research 35: 797-810. 
Zahner R. 1958. Hardwood understory depletes soil water in pine stands. Forest Science 4: 178-184.

Zimmermann A, Wilcke W, Elsenbeer H. 2007. Spatial and temporal patterns of throughfall quantity and quality in a tropical montane forest in Ecuador. Journal of Hydrology 343: $80-96$. 


\section{CHAPTER}

\section{4}

\section{Deposition and canopy exchange processes in central- \\ German beech forests differing in tree species diversity}

Ulrike Talkner, Inga Krämer, Dirk Hölscher \& Friedrich O. Beese

(accepted for publication in Plant and Soil, DOI: 10.1007/s11104-010-0491-2)

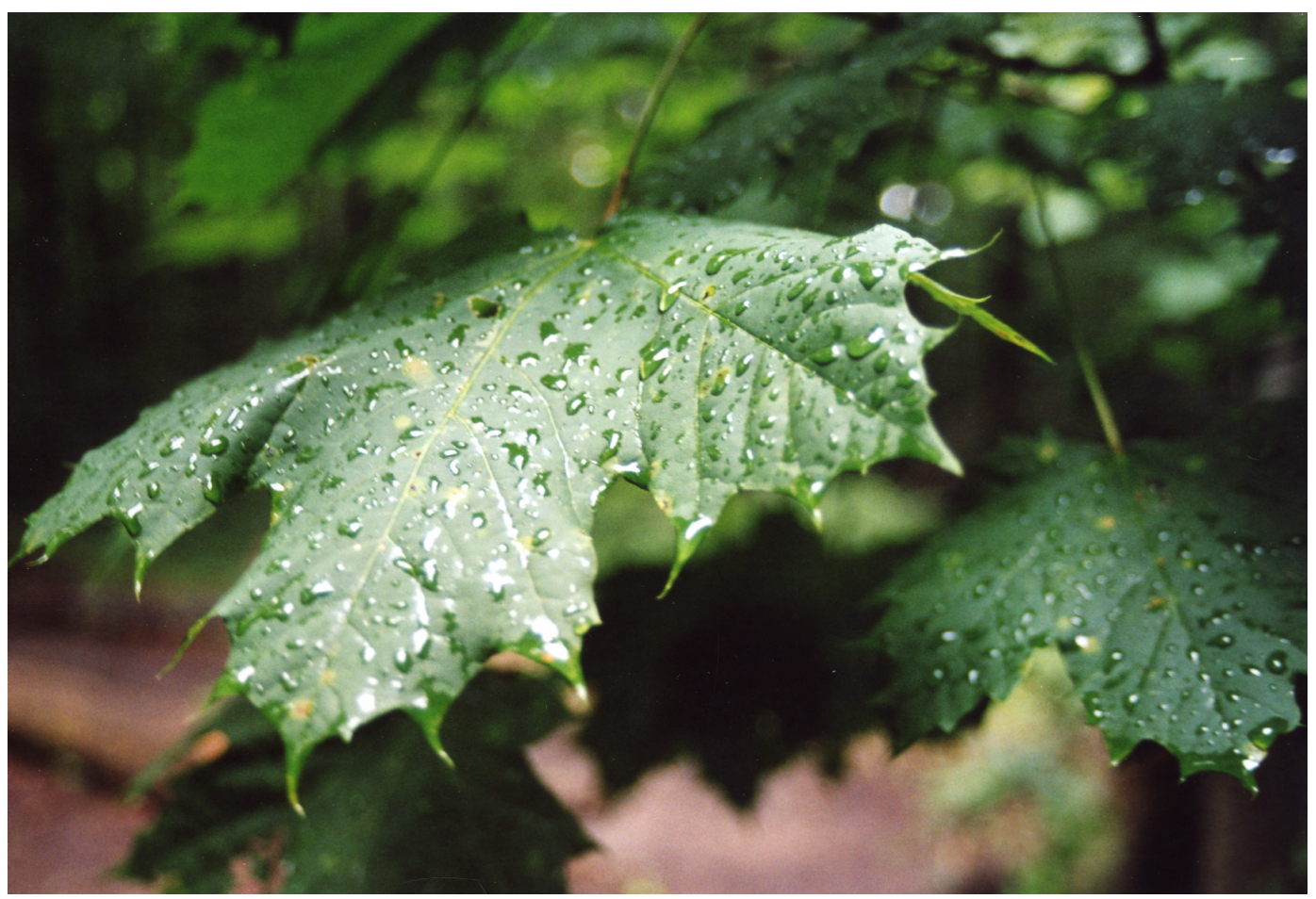




\subsection{ABSTRACT}

Atmospheric deposition is an important nutrient input to forests. The chemical composition of the rainfall is altered by the forest canopy due to interception and canopy exchange. Bulk deposition and stand deposition (throughfall plus stemflow) of $\mathrm{Na}^{+}, \mathrm{Cl}^{-}, \mathrm{K}^{+}, \mathrm{Ca}^{2+}, \mathrm{Mg}^{2+}, \mathrm{PO}_{4}{ }^{3-}$ , $\mathrm{SO}_{4}{ }^{2-}, \mathrm{H}^{+}, \mathrm{Mn}^{2+}, \mathrm{Al}^{3+}, \mathrm{Fe}^{2+}, \mathrm{NH}_{4}{ }^{+}, \mathrm{NO}_{3}{ }^{-}$and $\mathrm{N}_{\text {org }}$ were measured in nine deciduous forest plots with different tree species diversity in central Germany. Interception deposition and canopy exchange rates were calculated with a canopy budget model. The investigated forest plots were pure beech (Fagus sylvatica L.) plots, three-species plots (Fagus sylvatica, Tilia cordata Mill. or T. platyphyllos Scop. and Fraxinus excelsior L.) and five-species plots (Fagus sylvatica, T. cordata or T. platyphyllos, Fraxinus excelsior, Acer platanoides L., A. pseudoplatanus L. or A. campestre L. and Carpinus betulus L.). The interception deposition of all ions was highest in pure beech plots and was negatively related to the Shannon index. The stand deposition of $\mathrm{K}^{+}, \mathrm{Ca}^{2+}, \mathrm{Mg}^{2+}$ and $\mathrm{PO}_{4}{ }^{3-}$ was higher in mixed species plots than in pure beech plots due to higher canopy leaching rates in the mixed species plots. The acid input to the canopy and to the soil was higher in pure beech plots than in mixed species plots. The high canopy leaching rates of $\mathrm{Mn}^{2+}$ in pure beech plots indicated differences in soil properties between the plot types. Indeed, $\mathrm{pH}$, effective cation exchange capacity and base saturation were lower in pure beech plots. This may have contributed to the lower leaching rates of $\mathrm{K}^{+}, \mathrm{Ca}^{2+}$ and $\mathrm{Mg}^{2+}$ compared to the mixed species plots. However, foliar analyses indicated differences in the ion status among the tree species, which may additionally have influenced canopy exchange. In conclusion, the nutrient input to the soil resulting from deposition and canopy leaching was higher in mixed species plots than in pure beech plots, whereas the acid input was highest in pure beech plots.

\subsection{INTRODUCTION}

Atmospheric deposition is an important nutrient source in forests (e.g., Swank 1984; Lindberg et al. 1986). It is the total input of ions, gases and organic compounds to a canopy and can be divided into several fractions (Figure 4.1). Precipitation deposition, which is the deposition of rain, snow and particles that are deposited due to gravitation, is independent of the receptor surface (Ulrich 1983a). In contrast, interception deposition, which is the deposition of fog and cloud droplets, aerosols and gases, depends on the filtering efficiency of the receptor (size, structure and chemical state) (Ulrich 1983a). In the forest canopy, the receptor surface 
consists of leaves, branches, stems and canopy lichens. The canopy can act as a source or a sink for the deposited chemical compounds. The stand deposition is the output of ions and organic compounds from the canopy and consists of throughfall and stemflow, which together represent the input to the forest floor. The presence of understory vegetation in the forest alters the stand deposition before it reaches the soil.

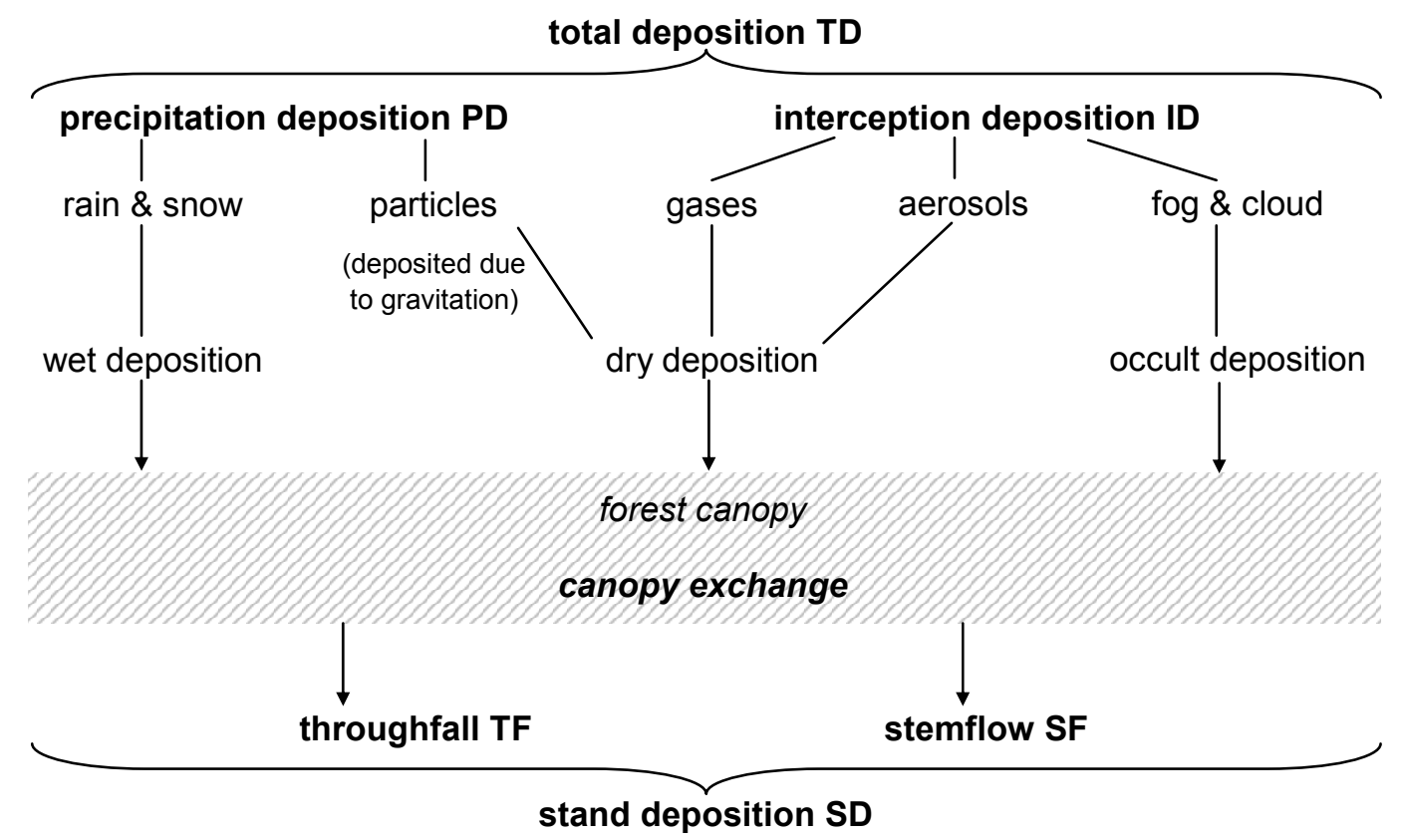

Figure 4.1 The deposition inputs and outputs of a forest canopy; adapted from Ulrich (1983a).

Stand precipitation is a major pathway in nutrient recycling, and annual nutrient return to the forest soil for potassium, sodium and sulphur is predominantly via stand precipitation, whereas little is due to litterfall (Parker 1983). However, deposited acid compounds and heavy metals can negatively influence the trees and the forest soil. Many authors have reported that this causes symptoms of forest decline in industrialized countries (e.g., Ulrich and Pankrath 1983; Georgii 1986; Johnson and Lindberg 1992; de Vries et al. 2001; Elling et al. 2007).

Several models have been developed to estimate interception deposition and canopy exchange on the basis of stand deposition and bulk or wet-only deposition measurements, e.g., the regression model of Lovett and Lindberg (1984) and the canopy budget models of Ulrich (1983a) and Beier et al. (1992). In the present study Ulrich's canopy budget model (1983a; 1994) was used to estimate interception deposition and canopy exchange. 
Besides abiotic factors, interception deposition depends on the leaf area, the physical and chemical properties of the leaf surface and the structural properties of the canopy (Erisman and Draaijers 2003; André et al. 2008). Interception deposition increases, for example, with increasing stand height and canopy roughness (Erisman and Draaijers 2003). The exchange processes in the canopy comprise uptake and leaching of chemical compounds and depend on the physiology and ion status of the trees and the ion permeability of the leaves (Draaijers et al. 1994; André et al. 2008). European beech (Fagus sylvatica L.) trees are known to have lower leaf ion concentrations than other deciduous trees, such as European hornbeam (Carpinus betulus L.) and small-leaved lime (Tilia cordata Mill.) (Krauß and Heinsdorf 2005). Hence, different tree species may affect interception and canopy exchange processes differently. Indeed, several studies have shown that stand deposition is significantly influenced by tree species composition (Potter et al. 1991; Draaijers et al. 1992; Lovett et al. 1996).

Because of changes in forest management, tree species diversity is increasing in German forests (Baumgarten and von Teuffel 2005; Knoke et al. 2005). However, how the alteration in tree species composition affects nutrient cycling in forests is not fully understood and has not yet been quantified. Hence, it is of interest to gain insight into the deposition and canopy exchange processes in mixed stands compared to single species ones (e.g., Nordén 1991; Berger et al. 2008).

We conducted an observational study in a temperate deciduous old-growth forest in central Germany to gain insight into the effects of tree species composition on deposition and canopy exchange processes. In contrast to observational studies, experiments in synthetic forest stands minimize the differences in soil properties and include all relevant treatments (monospecific plots of each tree species and all possible mixtures). However, planted synthetic stands often differ from natural forests in several respects, including trophic structure, tree age distribution and horizontal and vertical canopy structure (Leuschner et al. 2009). Furthermore, edge effects may interfere with species effects, and a quasi-steady state in soil development usually does not exist. Thus, experiments in planted synthetic stands should be combined with observational studies in existing forest stands differing in tree species diversity.

The present observational study examines the differences in the input of chemical compounds to the canopy with bulk and interception deposition, the canopy exchange processes, as well as the output of chemical compounds from the canopy with throughfall and stemflow along a 
tree species diversity gradient from monospecific beech plots to deciduous tree species-rich plots in central Germany.

\subsection{MATERIAL AND METHODS}

\section{Study site}

The study site $\left(51^{\circ} 5^{\prime} \mathrm{N}, 10^{\circ} 30^{\prime} \mathrm{E}\right)$ is located in central Germany in the Hainich National Park. The typical vegetation types of the National Park are beech and deciduous mixed-beech forests. The forest has not been managed and has only been used for recreation since 1990 . From the 1960 s to 1990 the area was used for military training. For the last 40 years, only single trees have been extracted from the forest, and it has regenerated naturally. The area has been covered by deciduous forest for at least 200 years. Thus, it represents an old-growth forest with respect to stand continuity according to Wulf's definition (2003) (Schmidt et al. 2009). The National Park is surrounded by deciduous forest, agricultural land and small villages. The nearest city (Erfurt) with more than 200,000 inhabitants is about $50 \mathrm{~km}$ to the southeast of the National Park.

Nine study plots (each 0.25 ha) with differing tree species diversity were selected within a radius of approximately $5 \mathrm{~km}$ in the north-eastern part of the Hainich National Park. The selected forest plots were located in a contiguous forest area. Each forest plot could be assigned to one of three tree species diversity levels (DL).

DL1: the tree layer comprises at least $95 \%$ beech (Fagus sylvatica L.);

DL2: the tree layer comprises at least $95 \%$ beech, lime (Tilia cordata Mill. or T. platyphyllos Scop.) and ash (Fraxinus excelsior L.);

DL3: the tree layer comprises at least 95\% beech, lime, ash, maple (Acer platanoides L., A. pseudoplatanus L. or A. campestre L.) and hornbeam (Carpinus betulus L.).

Three replicate plots were selected for each diversity level. The forest plots of DL1 are hereafter referred to as 'pure beech plots', and the forest plots of both DL2 and DL3, as 'mixed species plots'. The tree species composition in the Hainich National Park is largely a result of previous forest management. Different ownership and management goals have resulted in a small-scale mosaic of forest stands differing in tree species diversity with pure beech stands growing in close proximity to species-rich forests with ash, lime, hornbeam, maple and beech. The practice of selective cutting (Plenterwald) or coppicing with standards 
(Mittelwald), which promote the development of species-rich stands, was very probably associated with a higher disturbance regime for the past 150 to 200 years than that experienced in the management of beech in age-class forests (Schmidt et al. 2009). The average age of the trees is 148, 85 and 100 years in the DL1, DL2 and DL3 plots, respectively (Schmidt et al. 2009).

In the studied forest stands, trees began to acquire leaves in early April and leaf-out was completed by the second half of May. Leaf shedding started at the beginning of September. The trees were leafless from December to beginning of April.

The mean annual precipitation of the observation period (2005 to 2007) measured at the nearest meteorological station 'Weberstedt/Hainich' $\left(51^{\circ} 10^{\prime} \mathrm{N}, 10^{\circ} 52^{\prime} \mathrm{E} ; 270 \mathrm{~m}\right.$ a.s.1.) was $652 \mathrm{~mm}$ (meteomedia $\mathrm{GmbH}$ ). The long-term mean annual temperature is $7.5^{\circ} \mathrm{C}$. The study plots are located at a mean altitude of $340 \mathrm{~m}$ a.s.1., have a mean slope of $3.1^{\circ}$, and all plots have north-eastern exposure. The bedrock of the Hainich National Park is Triassic limestone covered with a loess layer of differing thickness. The soil type is a Luvisol (FAO 1998). The soil texture of the loess layer is loamy to clayey silt and in the lower parts of the profile, silty clay. The soils of the pure beech plots had lower base saturation (BS), lower effective cation exchange capacity $\left(\mathrm{CEC}_{\mathrm{e}}\right)$ and lower $\mathrm{pH}$ than the mixed species plots (Table 4.1) (Guckland et al. 2009).

Table 4.1 Mean values $(\bar{x})$ and standard deviations (s) of base saturation (BS), effective cation exchange capacity $\left(\mathrm{CEC}_{\mathrm{e}}\right)$ and $\mathrm{pH}$ in the mineral topsoil $(0-10 \mathrm{~cm})$ for each diversity level (DL1, DL2, DL3); $\mathrm{N}=3$ (Guckland et al. 2009).

\begin{tabular}{ccccc}
\hline DL & & $\begin{array}{c}\mathrm{BS} \\
(\%)\end{array}$ & $\begin{array}{c}\mathrm{CEC}_{\mathrm{e}} \\
\left(\mathrm{mmol}(+) \mathrm{kg}^{-1}\right)\end{array}$ & $\mathrm{pH}_{\mathrm{H} 2 \mathrm{O}}$ \\
\hline DL1 & $\bar{x}$ & $\mathbf{1 9}$ & $\mathbf{7 3}$ & $\mathbf{4 . 2}$ \\
& $\mathrm{s}$ & 4 & 13 & 0.2 \\
DL2 & $\bar{x}$ & $\mathbf{7 9}$ & $\mathbf{1 2 0}$ & $\mathbf{5 . 1}$ \\
& $\mathrm{s}$ & 6 & 43 & 0.1 \\
DL3 & $\bar{x}$ & $\mathbf{8 4}$ & $\mathbf{1 5 3}$ & $\mathbf{5 . 3}$ \\
& $\mathrm{s}$ & 11 & 56 & 0.2 \\
\hline
\end{tabular}

The Shannon diversity index was used as a measure of diversity (Shannon and Weaver 1949). It! is one of the most common measures for species diversity and depends not only on the number of species present in an ecosystem, but also on their relative abundance (Magurran 
2004). In the study area, Tilia cordata and T. platyphyllos often hybridized. Hence, T. cordata and T. platyphyllos were considered as one species in the calculation of the Shannon index. The relative abundance of each species was based on the number of stems. Using the basal area as a measure for the relative abundance led to very similar values for the Shannon index. The average height of the tallest $20 \%$ of the trees was used (tree height: M. Jacob, pers. comm.) as the stand height. Canopy roughness was defined by the height difference between the mean height of the tallest $10 \%$ and smallest $10 \%$ of the trees. The leaf area index (LAI; leaf area in $\mathrm{m}^{2} \mathrm{~m}^{-2}$ ) of the study plots was based on leaf biomass (Jacob et al. 2010). Therefore, litter traps were placed next to the precipitation collectors (see 'Rain water sampling and chemical analyses') and emptied several times during autumnal leaf shedding. Leaves of all species were scanned and the leaf area was analyzed using WinFOLIA (Regent Instruments, Canada). Subsequently, all leaves were dried and weighed, and the specific leaf area (SLA) was calculated. The LAI was obtained by multiplying the stand leaf biomass of each species by the species-specific average of SLA (Jacob et al. 2010). The primary differences in the forest stand characteristics of the tree layer were found between the pure beech plots and the mixed species plots (Table 4.2). The characteristics of the mixed species plots of DL2 did not differ substantially from those of DL3.

Table 4.2 Mean values $(\bar{x})$ and standard deviations (s) of the forest stand characteristics for each tree species diversity level (DL1: pure beech plots, DL2: mixed species plots with three main tree species, DL3: mixed species plots with five main tree species); $\mathrm{N}=3$. ${ }^{\mathrm{a}} \mathrm{M}$. Jacob, pers. comm.; ${ }^{\mathrm{b}}$ Krämer and Hölscher 2009; ${ }^{c}$ Jacob et al. 2010; the mean values of the leaf area index (LAI) of three years $(2005,2006,2007)$ are presented.

\begin{tabular}{|c|c|c|c|c|}
\hline \multirow[t]{2}{*}{$\mathrm{DL}$} & $\begin{array}{c}\text { Shannon } \\
\text { index }\end{array}$ & $\begin{array}{c}\text { Stand } \\
\text { height }^{\mathrm{a}}\end{array}$ & $\begin{array}{c}\text { Canopy } \\
\text { roughness }\end{array}$ & \multirow{2}{*}{$\begin{array}{c}\mathrm{LAI}^{\mathrm{c}} \\
\left(\mathrm{m}^{2} \mathrm{~m}^{-2}\right)\end{array}$} \\
\hline & & & m) & \\
\hline \multirow[t]{2}{*}{ DL1 } & 0.27 & 38 & 26 & 6.4 \\
\hline & 0.26 & 2.7 & 7.4 & 0.6 \\
\hline \multirow[t]{2}{*}{ DL2 } & 1.00 & 31 & 20 & 6.9 \\
\hline & 0.18 & 1.3 & 1.5 & 0.4 \\
\hline \multirow[t]{2}{*}{ DL3 } & 1.25 & 29 & 18 & 7.1 \\
\hline & 0.04 & 0.5 & 0.8 & 0.2 \\
\hline
\end{tabular}




\section{Rain water sampling and chemical analyses}

The following fractions of the rain water were sampled every two weeks: bulk precipitation, throughfall and stemflow. Bulk precipitation was sampled at four sites outside the forest, each with three continuously open precipitation collectors. At each site, the three collectors were placed in a triangle with a side length of $2 \mathrm{~m}$. The sites were located about $50 \mathrm{~m}$ from the forest edge, and the distance to the selected forest plots ranged from $200 \mathrm{~m}$ to $1200 \mathrm{~m}$. For the chemical analyses, the water of the three precipitation collectors of each site was pooled, resulting in four replicate samples per date for the bulk precipitation. Throughfall was sampled with a total of 15 throughfall collectors on each forest plot. The collectors were located along three randomly selected $30 \mathrm{~m}$ long transects with five collectors along each transect. The collector positions along transects were defined randomly with a minimum distance of $4 \mathrm{~m}$ between collectors. For the chemical analyses, the water of the five throughfall collectors on each transect was pooled, resulting in three replicate samples per forest plot and date for the throughfall. The collectors used for bulk precipitation and throughfall sampling were placed at a height of $1 \mathrm{~m}$ and had a diameter of $10.5 \mathrm{~cm}$. They were opaque to prevent the growth of algae. In the winter, snow was sampled with buckets. The diameter of the buckets was $25 \mathrm{~cm}$, and the sampling design was the same as that used during the remainder of the year. The stemflow was sampled adjacent to the selected forest plots on a total of 50 trees representing the tree species and the diameter classes found on the forest plots. All stemflow samples were analyzed chemically. The stemflow volume per plot was calculated using species-specific regressions between the diameter at breast height (dbh) and stemflow volume per measuring period combined with stem number and dbh of the trees on the study plots. When there was no persistent correlation between dbh and stemflow for a certain species, an average value of the stemflow volume of all the measured trees of this species was calculated. The concentration of all investigated chemical compounds was multiplied by the water volume of each sample; this provided in the quantity of each chemical compound per sample. For each tree species the median of this quantity was calculated and divided by the water volume per tree species, which determined the concentration of each chemical compound per tree species. This concentration was finally multiplied by the water volume per plot and upscaled to one hectare, which provided the stemflow quantity of each chemical compound per hectare $\left(\mathrm{kg} \mathrm{ha}^{-1}\right)$.

Bulk precipitation and throughfall were sampled manually every two weeks during a two-year period from July 2005 through June 2007. The stemflow was sampled manually every two 
weeks for a one-year period from July 2006 through June 2007. For further details on the water sampling see Krämer and Hölscher (2009).

The water samples were filtered through a Whatman 589/1 filter paper with a pore size of 12 $25 \mu \mathrm{m}$ and stored at $3^{\circ} \mathrm{C}$ until the chemical analyses were performed. The ions $\mathrm{Na}^{+}, \mathrm{K}^{+}, \mathrm{Ca}^{2+}$, $\mathrm{Mg}^{2+}, \mathrm{PO}_{4}{ }^{3-}, \mathrm{SO}_{4}{ }^{2-}, \mathrm{H}^{+}, \mathrm{Mn}^{2+}, \mathrm{Al}^{3+}$ and $\mathrm{Fe}^{2+}$ were measured by inductively coupled plasma atomic emission spectroscopy (ICP-AES, Spectro, Kleve, Germany). $\mathrm{Cl}^{-}$was measured potentiometrically, and the $\mathrm{N}$ compounds, photometrically, both with an automated continuous-flow analyzer (Skalar Analytic GmbH, Breda, The Netherlands). Carbon (C) compounds were measured by an automated C analyzer (Shimadzu TOC-5050, Duisburg, Germany).

\section{Canopy budget model}

This section briefly describes the canopy budget model that we used for calculating interception deposition, total deposition and canopy exchange. For more detailed explanations see Ulrich (1983a; 1994) and Bredemeier (1988). The total atmospheric deposition (TD) of an ecosystem is the sum of the precipitation deposition (PD) and the interception deposition (ID); the latter can be gaseous (ID gas) or particulate (ID $\mathrm{IDart})$. We used continuously open collectors outside the forest to measure precipitation deposition. Hence, we did not measure wet-only, but bulk deposition (BD) (Eq. [1]).

$$
\mathrm{TD}=\mathrm{BD}+\mathrm{ID}
$$

Bulk deposition is the sum of wet deposition and particles that are deposited due to gravitation. In addition, gaseous deposition may also be sampled with continuously open collectors, depending on the duration of surface wetness of the collectors (Cape and Leith 2002). The stand deposition (SD) is the sum of the deposition with throughfall (TF) and stemflow (SF), which were both measured in the field (Eq. [2]).

$$
\mathrm{SD}=\mathrm{TF}+\mathrm{SF}
$$

Leaves, branches and stems can act as sinks or sources of ions for the water passing through the canopy (throughfall) and along the stem (stemflow). This canopy exchange (CE) can be described by the difference between total deposition (TD) and stand deposition (SD) (Eq. [3]).

$$
\mathrm{CE}=\mathrm{TD}-\mathrm{SD}=\mathrm{BD}+\mathrm{ID}-\mathrm{SD}
$$

The difference can either be positive, which means that the canopy acts as a sink and the ions are taken up by the canopy, or negative, which means that the canopy acts as a source and the ions are leached from the canopy. Several processes contribute to the sink function of the 
forest canopy: assimilation $\left(\mathrm{NH}_{4}^{+}, \mathrm{NO}_{3}{ }^{-}\right.$) (Boynton 1954; Matzner 1986), cation exchange in the leaf tissue (exchange of $\mathrm{H}^{+}$for $\mathrm{Ca}^{2+}$ and $\mathrm{Mg}^{2+}$ ) (Ulrich 1983b; Roelofs et al. 1985), storage of particles $\left(\mathrm{Al}^{3+}\right.$, heavy metals) and precipitation of dissolved ions $\left(\mathrm{Al}^{3+}\right.$, heavy metals) (Godt 1986). Other processes contribute to the source function of the forest canopy: leaching of ions from senescent leaves mainly in autumn $\left(\mathrm{Na}^{+}, \mathrm{Mg}^{2+}, \mathrm{Ca}^{2+}, \mathrm{Cl}^{-}, \mathrm{SO}_{4}{ }^{2-}\right)$ (Ulrich 1983a), leaching of ions throughout the growing season due to metabolic processes $\left(\mathrm{K}^{+}\right.$, $\mathrm{Mn}^{2+}$ ) (Ulrich 1983a), cation exchange in the leaf tissue (exchange of $\mathrm{K}^{+}, \mathrm{Ca}^{2+}, \mathrm{Mg}^{2+}$ for $\mathrm{H}^{+}$ or $\mathrm{NH}_{4}^{+}$) (Ulrich 1983a; b; Stachurski and Zimka 2002), simultaneous leaching of cations $\left(\mathrm{K}^{+}, \mathrm{Ca}^{2+}, \mathrm{Mg}^{2+}\right)$ and weak acids (e.g., weak organic anions, bicarbonate) (Draaijers and Erisman 1995; Chiwa et al. 2004) and dissolution of undissolved matter in deposited particles $\left(\mathrm{Al}^{3+}\right.$, heavy metals) (Mayer 1983). It is often assumed that $\mathrm{Na}^{+}, \mathrm{Cl}^{-}, \mathrm{SO}_{4}{ }^{2-}$ and $\mathrm{NO}_{3}{ }^{-}$are neither leached from nor taken up by the forest canopy (Lindberg et al. 1986; Matzner 1986; Ulrich 1994; Draaijers and Erisman 1995). However, other authors state that there is canopy leaching of $\mathrm{Na}^{+}, \mathrm{Cl}^{-}$and $\mathrm{SO}_{4}{ }^{2-}$ and canopy uptake of $\mathrm{NO}_{3}{ }^{-}$(Staelens et al. 2008). It may be assumed that leaching is negligible for those ions whose stand deposition to bulk deposition ratio is constant throughout the year. In the present study this was the case for $\mathrm{Na}^{+}$, but not for $\mathrm{Cl}^{-}, \mathrm{SO}_{4}{ }^{2-}$ and $\mathrm{NO}_{3}{ }^{-}$. Consequently, we set the canopy exchange of $\mathrm{Na}^{+}$to zero and used it as a tracer ion for the calculation of particulate interception deposition of several other ions. One major assumption of the canopy budget model is that the interception rate depends on the precipitation deposition (in our case bulk deposition) and not on the ions. Because $\mathrm{Na}^{+}$is not exchanged in the canopy and does not exist in gaseous form, the particulate interception deposition can be calculated directly from stand deposition and bulk deposition according to Eq. [3]. The ratio of particulate interception deposition to bulk deposition for $\mathrm{Na}^{+}$was then used to calculate particulate interception deposition of the following ions: $\mathrm{Cl}^{-}, \mathrm{K}^{+}, \mathrm{Ca}^{2+}, \mathrm{Mg}^{2+}$, $\mathrm{PO}_{4}{ }^{3-}, \mathrm{SO}_{4}{ }^{2-}, \mathrm{H}^{+}, \mathrm{Mn}^{2+}, \mathrm{Al}^{3+}, \mathrm{Fe}^{2+}, \mathrm{NH}_{4}{ }^{+}$and $\mathrm{NO}_{3}{ }^{-}$. The assumption that particles containing these ions are deposited with the same efficiency as particles containing $\mathrm{Na}^{+}$might not be true (Draaijers et al. 1997). However, the error introduced by this assumption is probably the same for all study plots since they are located in one coherent forest area. Thus, it is possible to compare interception deposition and canopy exchange between the study plots. The ions $\mathrm{Cl}^{-}$, $\mathrm{SO}_{4}{ }^{2-}, \mathrm{H}^{+}, \mathrm{NH}_{4}{ }^{+}$and $\mathrm{NO}_{3}{ }^{-}$may also be deposited as gases. Since it was not possible to estimate the gas deposition, total deposition and canopy uptake of these ions might be underestimated and canopy leaching, overestimated.

The canopy leaching of $\mathrm{K}^{+}, \mathrm{Ca}^{2+}$ and $\mathrm{Mg}^{2+}$ is assumed to be accompanied by the uptake of $\mathrm{H}^{+}$ and $\mathrm{NH}_{4}{ }^{+}$or the leaching of weak acids. Thus, the canopy exchange of $\mathrm{H}^{+}$and $\mathrm{NH}_{4}^{+}$can be 
calculated by subtracting the leaching of $\mathrm{K}^{+}, \mathrm{Ca}^{2+}$ and $\mathrm{Mg}^{2+}$ from the leaching of weak acids (Draaijers and Erisman 1995; Staelens et al. 2008). The quantity of weak acids in bulk deposition and stand deposition can be calculated from the cation-anion balance (Draaijers and Erisman 1995; Staelens et al. 2008). To separate the uptake of $\mathrm{H}^{+}$and $\mathrm{NH}_{4}{ }^{+}$, a relative uptake efficiency factor is normally used. However, this factor is tree-species specific (Staelens et al. 2008) and has not been determined for beech or any of the other tree species present on the study plots. Consequently, we did not use this approach. De Vries et al. (2001) suggested a method for calculating the canopy uptake of $\mathrm{NO}_{3}{ }^{-}$. Since this approach is dependent on the uptake of $\mathrm{NH}_{4}{ }^{+}$and again an efficiency factor for the uptake of $\mathrm{NH}_{4}{ }^{+} \mathrm{vs}$. $\mathrm{NO}_{3}{ }^{-}$has to be used, we considered this calculation to be too unreliable.

The acid input to the forest canopies was calculated as the sum of the total deposition of the cations $\mathrm{H}^{+}, \mathrm{Mn}^{2+}, \mathrm{Al}^{3+}, \mathrm{Fe}^{2+}$ and $\mathrm{NH}_{4}^{+}$(Ulrich 1994). The acid buffering capacity of the canopies was calculated as the sum of the positive canopy exchange, that is, the uptake of the cations $\mathrm{H}^{+}, \mathrm{Mn}^{2+}, \mathrm{Al}^{3+}, \mathrm{Fe}^{2+}$ and $\mathrm{NH}_{4}^{+}$(Ulrich 1994).

\section{Data analyses and statistics}

The concentrations of the chemical compounds of bulk precipitation, throughfall and stemflow were checked for outliers. These outliers were identified by very high $\mathrm{C}, \mathrm{N}, \mathrm{P}$ or K contents. In total 40 out of 1060 data points (i.e., less than 4\%) were removed from the dataset before doing any calculations. Since we had three pooled samples per study plot and date and we never had to remove all of them, the deletion of single data points still allowed the calculation of annual budgets.

The chemical analyses of the bulk precipitation samples revealed that the four sites outside the forest had a large variation in chemical composition among the sampling dates and the sites, but there were no consistent differences between the four sites. Hence, the sites were regarded as replicates for the bulk precipitation and mean values of the four replicate sites were calculated.

Mean values per sampling date were calculated for each forest plot using the three pooled throughfall samples per plot. The mean values of the three replicate forest plots at each diversity level were used for further calculations and statistical analyses because the forest plots are our true replicates. The mean values for each sampling date during the two year measurement period were summed up; this provided the values for the annual precipitation 
and throughfall fluxes. The mean value of the two annual fluxes was calculated to smooth annual fluctuations.

The stemflow data were also summed up to provide a one-year sum. To estimate the sum of the first year (July 2005 to June 2006), for which no stemflow data were available, the ratio of stemflow to throughfall for each plot and chemical compound of the second year (July 2006 to June 2007) was calculated and multiplied with the throughfall for each plot and chemical compound of the first year. Again, the mean value of the two annual fluxes was calculated to smooth annual fluctuations.

The two-year means of the throughfall and stemflow data were summed up to reveal the stand deposition. The two-year means of the bulk deposition (BD) and the stand deposition (SD) were used to calculate the interception deposition (ID), the total deposition (TD) and the canopy exchange (CE) of each plot and chemical compound as described above (see 'Canopy budget model').

The study objective was to evaluate differences in the interception deposition, total deposition, canopy exchange and stand deposition between the diversity levels and along the tree species diversity gradient. Therefore, the two-year means of the interception deposition, total deposition, canopy exchange and stand deposition of every chemical compound were used as dependent variables in an analysis of variance (ANOVA) with the diversity level as the explaining variable. Differences between the diversity levels were deemed to be significant if they exceeded the least significant difference, LSD, computed for every pair of diversity levels $(\mathrm{p}<0.05)$. In addition, interception deposition, total deposition, canopy exchange and stand deposition on each plot and of each chemical compound were used in a multiple linear regression model with the Shannon index and the leaf area index (LAI) as explaining variables. The ANOVA with diversity level as explaining variable and the multiple linear regression model with Shannon index and LAI as explaining variables are different approaches toward elucidating the influence of the tree species composition on deposition and canopy exchange.

All statistical analyses were done with R version 2.7.2 (R Development Core Team 2007). 


\subsection{RESULTS}

\section{Forest stand characteristics}

The investigated forest plots differed in their stand characteristics (Table 4.2). Pure beech plots (i.e., lowest Shannon index) were taller and had rougher canopies than mixed species plots. Shannon index, stand height and canopy roughness correlated significantly with one another, whereas LAI only correlated with stand height (Table 4.3).

Table 4.3 P-values and correlation coefficients of the Pearson's product-moment correlations with stand characteristics as variables; $* 0.01 \leq \mathrm{p}<0.05, * * 0.001 \leq \mathrm{p}<0.01, * * * \mathrm{p}<0.001$.

\begin{tabular}{lllr}
\hline Variable 1 & Variable 2 & $\mathrm{p}$ & $\mathrm{r}$ \\
\hline Shannon index & stand height & $<\mathbf{0 . 0 0 1} * * *$ & $\mathbf{- 0 . 9 7}$ \\
Shannon index & canopy roughness & $\mathbf{0 . 0 0 3} * *$ & $\mathbf{- 0 . 8 6}$ \\
Shannon index & LAI & 0.09 & 0.59 \\
stand height & canopy roughness & $\mathbf{0 . 0 0 4} * *$ & $\mathbf{0 . 8 4}$ \\
stand height & LAI & $\mathbf{0 . 0 4} *$ & $\mathbf{- 0 . 6 9}$ \\
canopy roughness & LAI & 0.30 & -0.39 \\
\hline
\end{tabular}

Since most of the stand characteristics were linearly correlated, the effects of single stand characteristics on the canopy deposition and exchange processes could not be isolated. We used the Shannon index as a measure for the correlated stand characteristics and the LAI as an additional stand characteristic in a multiple linear regression model to explain differences in interception deposition, canopy exchange and stand deposition.

\section{Variations in ion fluxes}

During the course of the year the ratio of stand deposition to bulk deposition was constant for $\mathrm{Na}^{+}$, whereas this ratio was much larger in summer and autumn than during the rest of the year for the ions $\mathrm{K}^{+}, \mathrm{Ca}^{2+}, \mathrm{Mg}^{2+}$ and to a lesser extent also for $\mathrm{Cl}^{-}, \mathrm{PO}_{4}{ }^{3-}, \mathrm{SO}_{4}{ }^{2-}$ and $\mathrm{NO}_{3}{ }^{-}$. This indicates that $\mathrm{Na}^{+}$was not exchanged in the canopy, whereas the other ions were leached from the canopy during summer and autumn, which resulted in seasonal variations.

The quantity of stemflow was very low compared to the quantity of bulk precipitation and throughfall ( $0.4 \%$ to $4.9 \%$ of bulk precipitation) (Krämer and Hölscher 2009); hence, the ion 
fluxes were generally also very low. The stemflow fluxes of the ions were on average $3.7 \%$ of the throughfall fluxes, with $\mathrm{H}^{+}$having the lowest percentage $(0.2 \%)$ and $\mathrm{Al}^{3+}$ having the highest (17.6\%). Stemflow fluxes did not differ between the diversity levels.

\section{Deposition and canopy exchange}

Total and interception deposition of all ions significantly decreased with increasing diversity level (ANOVA) and were negatively related to the Shannon index but not related to the LAI (multiple linear regression model; adjusted $\mathrm{R}^{2}=0.86$, Shannon index: $\mathrm{p}<0.001$, LAI: $\mathrm{p}=0.10$ ). The interception deposition was calculated in the same manner for all ions. Hence, the differences in interception deposition between the diversity levels were the same for all ions. Since the total deposition is the sum of bulk deposition and interception deposition and the bulk deposition is the same for all diversity levels, the differences between the diversity levels for total deposition were the same as those for interception deposition.

There was no indication of meaningful $\mathrm{Na}^{+}$canopy exchange in the study plots. Most of the other ions were leached from the canopy (Table 4.4). Only $\mathrm{NH}_{4}{ }^{+}$was taken up in all investigated forest plots, and $\mathrm{H}^{+}$ions were taken up in the mixed species plots and leached in the pure beech plots. The results of the ANOVA showed that the canopy exchange rates of most of the ions were different in pure beech than in mixed species plots, only the exchange rates of $\mathrm{Al}^{3+}, \mathrm{NH}_{4}{ }^{+}$, and $\mathrm{NO}_{3}{ }^{-}$were comparable in all investigated forest plots. The canopy leaching of $\mathrm{Cl}^{-}, \mathrm{K}^{+}, \mathrm{Ca}^{2+}, \mathrm{Mg}^{2+}, \mathrm{PO}_{4}{ }^{3-}, \mathrm{SO}_{4}{ }^{2-}$, and $\mathrm{Fe}^{2+}$ increased with increasing diversity level, whereas the leaching of $\mathrm{Mn}^{2+}$ was largest in the pure beech plots. The multiple linear regression model revealed that the exchange rates of $\mathrm{Mg}^{2+}, \mathrm{PO}_{4}{ }^{3-}, \mathrm{SO}_{4}{ }^{2-}, \mathrm{Al}^{3+}, \mathrm{Fe}^{2+}, \mathrm{NH}_{4}{ }^{+}$and $\mathrm{NO}_{3}{ }^{-}$were not related to the Shannon index (Table 4.5). The leaching of $\mathrm{Cl}^{-}, \mathrm{K}^{+}$and $\mathrm{Ca}^{2+}$ was positively related to it, and the leaching of $\mathrm{Mn}^{2+}$ was negatively related to the Shannon index (Table 4.5 and Figure 4.2). No canopy exchange rate of any ion was related to the LAI.

According to the canopy exchange rates, the stand deposition of $\mathrm{Na}^{+}, \mathrm{Cl}^{-}, \mathrm{K}^{+}, \mathrm{Ca}^{2+}, \mathrm{Mg}^{2+}$, $\mathrm{PO}_{4}{ }^{3-}, \mathrm{Fe}^{2+}$ and $\mathrm{N}_{\text {org }}$ was larger in mixed species plots than in pure beech plots, whereas the stand deposition of $\mathrm{H}^{+}, \mathrm{Mn}^{2+}$ and $\mathrm{NH}_{4}^{+}$was largest in pure beech plots, and did not differ among the diversity levels for $\mathrm{SO}_{4}{ }^{2-}, \mathrm{Al}^{3+}, \mathrm{NO}_{3}{ }^{-}$and $\mathrm{N}_{\mathrm{t}}$. Stand deposition was positively related to the Shannon index for $\mathrm{K}^{+}$and $\mathrm{Ca}^{2+}$ and negatively related to it for $\mathrm{Na}^{+}, \mathrm{H}^{+}, \mathrm{Mn}^{2+}$, $\mathrm{NH}_{4}{ }^{+}, \mathrm{NO}_{3}{ }^{-}$and $\mathrm{N}_{\mathrm{t}}$ (Table 4.5). The stand deposition of $\mathrm{Cl}^{-}, \mathrm{Mg}^{2+}, \mathrm{PO}_{4}{ }^{3-}, \mathrm{SO}_{4}{ }^{2-}, \mathrm{Al}^{3+}, \mathrm{Fe}^{2+}$ and $\mathrm{N}_{\text {org }}$ was not related to the Shannon index. Only the stand deposition of $\mathrm{NO}_{3}{ }^{-}$was positively related to the LAI. 
Table 4.4 Mean values $(\bar{x})$ and standard deviations (s) of the annual water and ion fluxes with precipitation deposition (PD), interception deposition (ID), total deposition (TD), canopy exchange (CE) and stand deposition (SD) for each diversity level (DL1, DL2, DL3); PD (N =4) and SD (N = 3) were measured in the field; ID $(\mathrm{N}=3), \mathrm{TD}(\mathrm{N}=3)$ and $\mathrm{CE}(\mathrm{N}=3)$ were calculated with the canopy budget model (Ulrich 1983a; Ulrich 1994); n.d. = not determined.

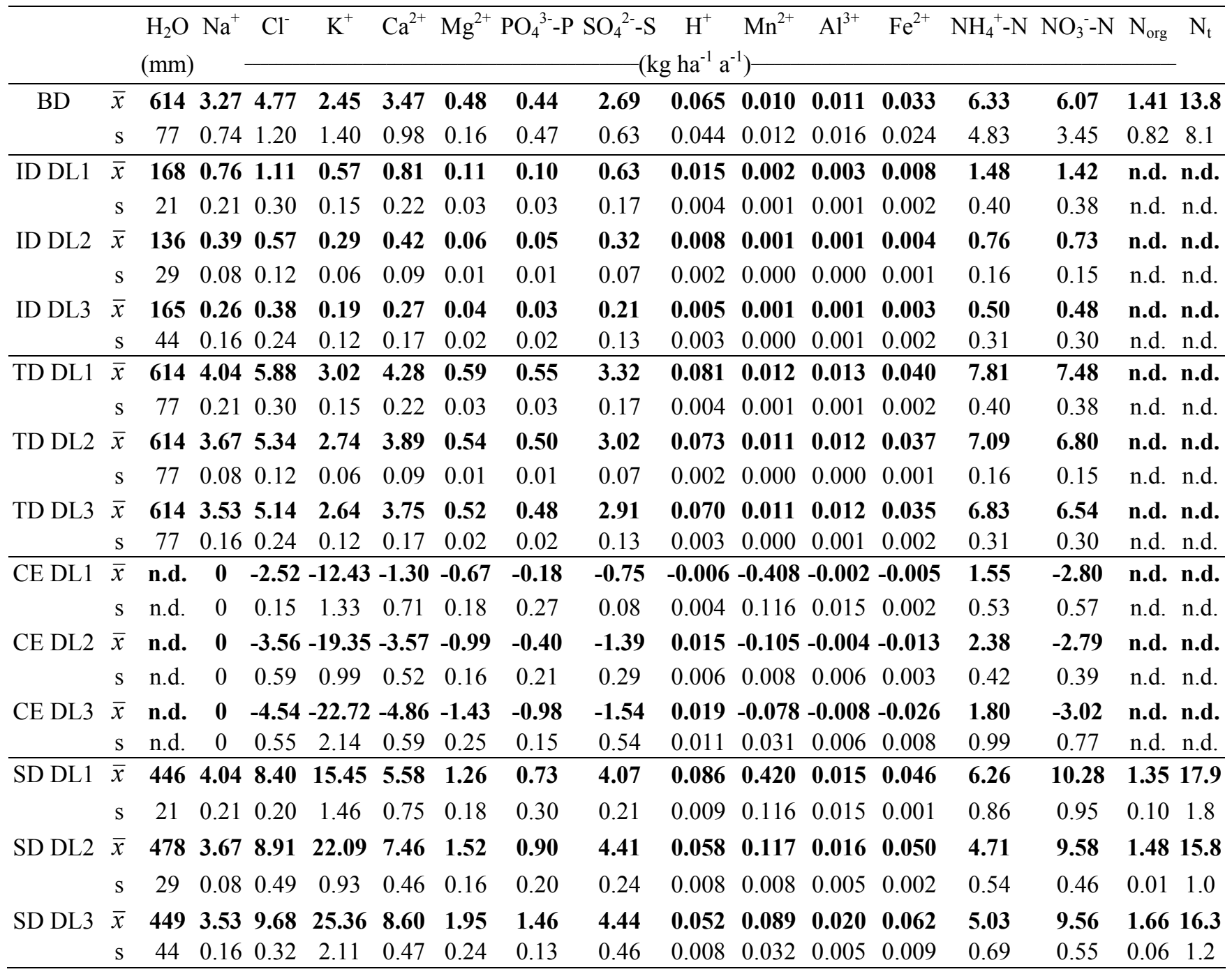

The acid input to the canopies of the study plots decreased with increasing diversity level (Figure 4.3) and was negatively related to the Shannon index but not to the LAI (adjusted $\mathrm{R}^{2}=0.86$, Shannon index: $\mathrm{p}<0.001$, LAI: $\mathrm{p}=0.10$ ). However, the acid buffering capacity of the canopies did not differ significantly between the diversity levels and was neither related to the Shannon index nor to the LAI (adjusted $R^{2}=-0.19$, Shannon index: $p=0.44$, LAI: $\mathrm{p}=0.79)$. 

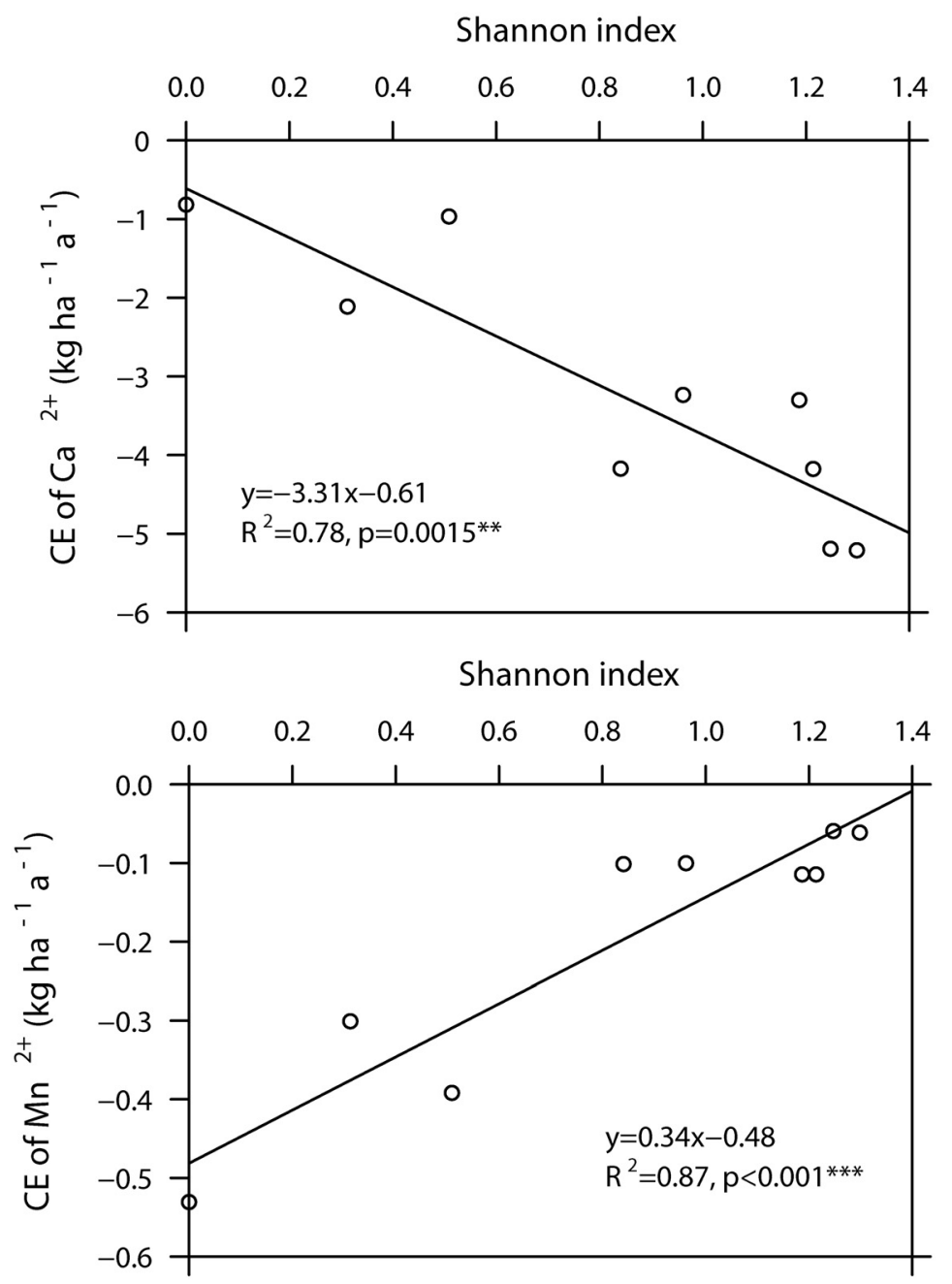

Figure 4.2 Relation between the canopy exchange (CE) of $\mathrm{Ca}^{2+}(\mathrm{a})$ and $\mathrm{Mn}^{2+}(\mathrm{b})$, respectively, and the Shannon index; the linear equations, the coefficients of determination $\left(\mathrm{R}^{2}\right)$ and the $\mathrm{p}$-values are given; $\mathrm{N}=9$.

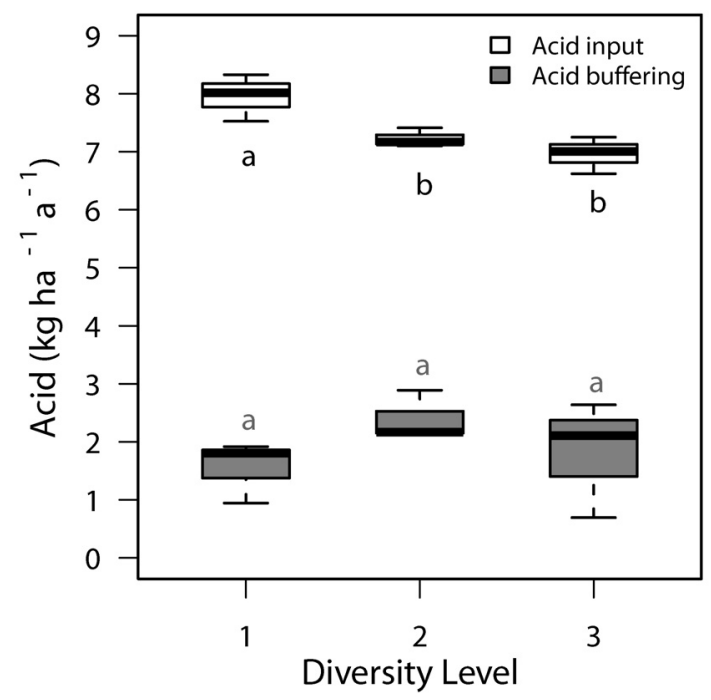

Figure 4.3 Acid input and acid buffering capacity of the forest canopy for each diversity level (DL1, DL2, DL3); $\mathrm{N}=3$. 
Table 4.5 P-values and adjusted coefficients of determination (adj. $\mathrm{R}^{2}$ ) of multiple linear regression models with Shannon index and LAI as explaining variables for the variance in canopy exchange and stand deposition of every chemical compound; $* 0.01 \leq \mathrm{p}<0.05, * * 0.001 \leq \mathrm{p}<0.01, * * * \mathrm{p}<0.001$.

\begin{tabular}{|c|c|c|c|c|c|}
\hline & & Canopy & xchange & Stand dep & sition \\
\hline & & $\mathrm{p}$ & adj. $R^{2}$ & $\mathrm{p}$ & adj. $R^{2}$ \\
\hline $\mathrm{Na}^{+}$ & $\begin{array}{l}\text { Shannon index } \\
\text { LAI }\end{array}$ & - & - & $\begin{array}{l}<\mathbf{0 . 0 0 1} * * * \\
0.10\end{array}$ & 0.86 \\
\hline $\mathrm{Cl}^{-}$ & $\begin{array}{l}\text { Shannon index } \\
\text { LAI }\end{array}$ & $\begin{array}{l}\mathbf{0 . 0 2} * \\
0.77\end{array}$ & 0.57 & $\begin{array}{l}0.12 \\
0.88\end{array}$ & 0.30 \\
\hline $\mathrm{K}^{+}$ & $\begin{array}{l}\text { Shannon index } \\
\text { LAI }\end{array}$ & $\begin{array}{l}\mathbf{0 . 0 1} \\
0.93\end{array}$ & 0.69 & $\begin{array}{l}\mathbf{0 . 0 2} * \\
0.89\end{array}$ & 0.67 \\
\hline $\mathrm{Ca}^{2+}$ & $\begin{array}{l}\text { Shannon index } \\
\text { LAI }\end{array}$ & $\begin{array}{l}\mathbf{0 . 0 1} \text { * } \\
0.67\end{array}$ & 0.72 & $\begin{array}{l}\mathbf{0 . 0 3} * \\
0.50\end{array}$ & 0.66 \\
\hline $\mathrm{Mg}^{2+}$ & $\begin{array}{l}\text { Shannon index } \\
\text { LAI }\end{array}$ & $\begin{array}{l}0.10 \\
0.55\end{array}$ & 0.46 & $\begin{array}{l}0.14 \\
0.47\end{array}$ & 0.41 \\
\hline $\mathrm{PO}_{4}^{3-}-\mathrm{P}$ & $\begin{array}{l}\text { Shannon index } \\
\text { LAI }\end{array}$ & $\begin{array}{l}0.23 \\
0.12\end{array}$ & 0.57 & $\begin{array}{l}0.35 \\
0.10\end{array}$ & 0.54 \\
\hline $\mathrm{SO}_{4}{ }^{2-}-\mathrm{S}$ & $\begin{array}{l}\text { Shannon index } \\
\text { LAI }\end{array}$ & $\begin{array}{l}0.06 \\
0.55\end{array}$ & 0.35 & $\begin{array}{l}0.35 \\
0.81\end{array}$ & -0.11 \\
\hline $\mathrm{H}^{+}$ & $\begin{array}{l}\text { Shannon index } \\
\text { LAI }\end{array}$ & $\begin{array}{l}\mathbf{0 . 0 2} * \\
0.70\end{array}$ & 0.57 & $\begin{array}{l}\mathbf{0 . 0 0 3} * * \\
0.41\end{array}$ & 0.78 \\
\hline $\mathrm{Mn}^{2+}$ & $\begin{array}{l}\text { Shannon index } \\
\text { LAI }\end{array}$ & $\begin{array}{l}\mathbf{0 . 0 0 3} * * \\
0.56\end{array}$ & 0.83 & $\begin{array}{l}\mathbf{0 . 0 0 3} * * \\
0.57\end{array}$ & 0.83 \\
\hline $\mathrm{Al}^{3+}$ & $\begin{array}{l}\text { Shannon index } \\
\text { LAI }\end{array}$ & $\begin{array}{l}0.99 \\
0.97\end{array}$ & -0.33 & $\begin{array}{l}0.85 \\
0.93\end{array}$ & -0.32 \\
\hline $\mathrm{Fe}^{2+}$ & $\begin{array}{l}\text { Shannon index } \\
\text { LAI }\end{array}$ & $\begin{array}{l}0.06 \\
0.77\end{array}$ & 0.48 & $\begin{array}{l}0.23 \\
0.60\end{array}$ & 0.24 \\
\hline $\mathrm{NH}_{4}{ }^{+}-\mathrm{N}$ & $\begin{array}{l}\text { Shannon index } \\
\text { LAI }\end{array}$ & $\begin{array}{l}0.45 \\
0.78\end{array}$ & -0.19 & $\begin{array}{l}\mathbf{0 . 0 3} \\
0.43\end{array}$ & 0.44 \\
\hline $\mathrm{NO}_{3}{ }^{-}-\mathrm{N}$ & $\begin{array}{l}\text { Shannon index } \\
\text { LAI }\end{array}$ & $\begin{array}{l}0.37 \\
0.12\end{array}$ & 0.15 & $\begin{array}{l}0.004 * * \\
0.02 *\end{array}$ & 0.70 \\
\hline $\mathrm{N}_{\text {org }}$ & $\begin{array}{l}\text { Shannon index } \\
\text { LAI }\end{array}$ & - & - & $\begin{array}{l}0.15 \\
0.18\end{array}$ & 0.57 \\
\hline $\mathrm{N}_{\mathrm{t}}$ & $\begin{array}{l}\text { Shannon index } \\
\text { LAI }\end{array}$ & - & - & $\begin{array}{l}\mathbf{0 . 0 2} * \\
0.11\end{array}$ & $\mathbf{0 . 5 0}$ \\
\hline
\end{tabular}

\subsection{DISCUSSION}

\section{Comparison of deposition with other data}

In Germany, the fluxes of $\mathrm{Na}^{+}$and $\mathrm{Cl}^{-}$in precipitation decrease with increasing distance from the North Sea. This decrease is more pronounced in stand deposition than in bulk deposition, which indicates that interception of seaborne particles decreases rapidly with increasing distance from the shore (Bredemeier 1988). The molar ratio of $\mathrm{Na}^{+}$to $\mathrm{Cl}^{-}$is 0.86 in sea water. 
In the studied forest plots it was 1.08 for bulk deposition and 0.56 to 0.74 for stand deposition. This agrees with other studies (Bredemeier 1988; Nordén 1991). Since $\mathrm{Na}^{+}$was not meaningfully exchanged in the studied canopies (see next paragraph) and may be considered as solely derived from atmospheric sea salt deposition (Ulrich 1983a), the deviations of the measured ratios from the ratio in sea water have to be due to relatively more $\mathrm{Cl}^{-}$in the stand precipitation than in sea water. In addition, the ratio decreased with increasing diversity level. This can be explained by increasing canopy leaching rates for $\mathrm{Cl}^{-}$with increasing diversity level (see 'Differences in interception deposition and canopy exchange between the diversity levels').

The use of $\mathrm{Na}^{+}$as a tracer ion for calculating particulate interception deposition of other ions requires that $\mathrm{Na}^{+}$is not exchanged in the canopy. However, canopy leaching of $\mathrm{Na}^{+}$during the short period of leaf emergence was reported (Staelens et al. 2007). If ions are exchanged in the canopy, seasonal differences in the ratio of stand deposition to bulk deposition can be observed. For $\mathrm{Na}^{+}$, this ratio differed among sampling dates but did not differ among seasons or plots. In contrast, the stand deposition to bulk deposition ratio differed seasonally for the other ions that are often assumed to undergo no reactions in the canopy: $\mathrm{Cl}^{-}, \mathrm{SO}_{4}{ }^{2-}$ and $\mathrm{NO}_{3}{ }^{-}$. Thus, we concluded that $\mathrm{Na}^{+}$was not exchanged and, hence, can be used as a tracer ion in the canopy budget model. For the other ions, canopy exchange was assumed.

Compared with the total deposition of other German beech forests in the year 2002, the total deposition reported in the present study is approximately the same for $\mathrm{K}^{+}$and $80 \%$ and $90 \%$ lower for $\mathrm{Mg}^{2+}$ and $\mathrm{Ca}^{2+}$, respectively (Meesenburg et al. 2009). The bulk and stand deposition of $\mathrm{PO}_{4}{ }^{3-}$ were $80 \%$ to $95 \%$ higher in the investigated forest plots than in deciduous mixed forests in Southern Sweden (Nordén 1991). In contrast, the bulk and stand deposition of $\mathrm{SO}_{4}{ }^{2-}$ were $80 \%$ to $90 \%$ lower in the investigated forest plots than in German beech forests in the 1980s (Bredemeier 1988). This agrees with the reduced sulphur deposition in Germany during the last several decades (Meesenburg et al. 1995; Ulrich et al. 2006). Even compared with more recent data of similar German beech forests, the sulphur deposition of the investigated forest plots is more than 90\% lower (Meesenburg et al. 2009). This could be explained by the remote location of our forest plots. The stand and total depositions of $\mathrm{H}^{+}$and $\mathrm{Mn}^{2+}$ were $80 \%$ to $90 \%$ lower, and those of $\mathrm{NH}_{4}^{+} 50 \%$ to $60 \%$ lower in our study than reported in Nordén (1991), Matzner and Meiwes (1994) and Meesenburg et al. (2009), which indicates a reduction of acid emissions and the remote location of the study site. The stand deposition of $\mathrm{NO}_{3}{ }^{-}$was approximately the same as reported in Matzner and Meiwes (1994), and the total deposition, about $80 \%$ lower than reported in Meesenburg et al. (2009). Only 
small quantities of the total $\mathrm{N}$ deposited by throughfall were in organic form $(8 \%$ to $10 \%)$, whereas Gaige et al. (2007) reported that organic $\mathrm{N}$ made up more than $80 \%$ of $\mathrm{N}_{t}$ in throughfall.

In summary, total and stand deposition of $\mathrm{SO}_{4}{ }^{2-}, \mathrm{H}^{+}, \mathrm{Mn}^{2+}$ and $\mathrm{NH}_{4}{ }^{+}$reported in this paper were much lower than those reported in the above-mentioned studies, whereas total and stand deposition of $\mathrm{K}^{+}, \mathrm{Ca}^{2+}$ and $\mathrm{Mg}^{2+}$ were approximately the same as or also much lower than those reported in the above-mentioned studies. This agrees with the fact that the quantity of bulk precipitation of the investigated forest plots was either the same as or up to $35 \%$ lower than that reported in the other studies (Bredemeier 1988; Nordén 1991; Matzner and Meiwes 1994; Meesenburg et al. 2009), which is known to influence the deposition quantity of several ions (Croisé et al. 2005). In addition, not only the reduced emission of sulphur and to a lesser extent nitrogen during the last years, but also the remote location of the study area contributed to the low deposition of sulphur and nitrogen. The Federal Environmental Agency of Germany (UBA, 2006) reported values of $4 \mu \mathrm{g} \mathrm{NO}$ per $\mathrm{m}^{3}$ and $0.9 \mu \mathrm{g} \mathrm{SO}_{2}$ per $\mathrm{m}^{3}$ for June 2006 at a relatively unpolluted location about $70 \mathrm{~km}$ away from the study site.

\section{Differences in interception deposition and canopy exchange between the diversity levels}

The stand deposition of the investigated chemical compounds differed between the diversity levels, with the exceptions of $\mathrm{SO}_{4}{ }^{2-}, \mathrm{Al}^{3+}, \mathrm{NO}_{3}{ }^{-}$and $\mathrm{N}_{\mathrm{t}}$. Hence, the tree species composition may have influenced the nutrient input to the forest soil by altering the nutrient composition of rainfall while it was passing through the canopy (Potter et al. 1991; Draaijers et al. 1992; Lovett et al. 1996). Therefore, we will take a closer look at the processes in the canopy that may explain the observed differences in stand deposition among the forest plots: interception deposition and canopy exchange.

Interception deposition depends on the aerodynamic properties of the receiving surface (Erisman and Draaijers 2003). Properties determined by the canopy as a whole - such as canopy roughness, canopy length, canopy cover and LAI - influence the interception deposition, but also properties of individual canopy elements - such as the efficiency of leaves in capturing or absorbing gases and particles, or the surface wetness (Erisman and Draaijers 2003) - contribute to this. The pure beech plots were the tallest and had the roughest canopies of the study plots. This may be explained by the former management of the study plots and the tree species present. The beech plots were oldest and natural regeneration may have led to large height differences, which, in turn, result in their pronounced canopy 
roughness. The interception deposition of all ions was largest in the pure beech plots and negatively related to the Shannon index. The LAI did not explain any variation in the interception deposition. Since, with the exception of the LAI, the stand characteristics were correlated, it is not possible to isolate which factor contributed most to the differences in interception deposition among the study plots.

In summary, we can state that the interception deposition decreased along the investigated tree species diversity gradient from monospecific beech plots to tree species-rich plots. Ion deposition differed significantly between pure beech plots and mixed species plots, but did not differ significantly between the mixed species plots (DL2 and DL3). The same pattern was found for the stand characteristics (except for LAI); this may explain the differences in ion deposition along the investigated tree species diversity gradient. However, the differences in stand characteristics are probably not typical for other forests, which may for example have more pronounced canopy roughness in mixed than in single species stands.

The ions $\mathrm{Cl}^{-}, \mathrm{SO}_{4}{ }^{2-}, \mathrm{H}^{+}, \mathrm{NH}_{4}{ }^{+}$and $\mathrm{NO}_{3}{ }^{-}$may also originate from gas deposition. Because it was not possible to estimate the gas deposition, the total deposition and the canopy uptake of these ions might be underestimated and the canopy leaching, overestimated. For example, the canopy uptake of $\mathrm{NH}_{4}{ }^{+}$is likely to be underestimated, whereas the canopy leaching of $\mathrm{NO}_{3}{ }^{-}$, overestimated. Since the gaseous deposition is influenced by the stand characteristics, the actual differences in canopy exchange between the diversity levels might differ somewhat from the calculated differences. Hence, the interception and total deposition of these ions and also the calculated canopy exchange have to be interpreted with care.

Canopy exchange of ions can be due to passive diffusion between the water layer covering the leaves and the apoplast or due to ion exchange at cuticular exchange sites (Draaijers et al. 1994). Several factors affect these processes, some of which probably do not differ among the studied forest plots (foliar wax degradation, quantity and duration of precipitation and abiotic stresses), whereas others do. These factors are the wettability of foliage, which is found to differ considerably among tree species, tree physiology and possibly the age distribution of leaves (Draaijers et al. 1994). Hence, differences in the canopy exchange between the diversity levels may be due to differences in the above-mentioned factors among the tree species. In addition, the differences in canopy exchange may also arise from differences in soil properties, which are likely to affect the foliar ion status and canopy exchange (Nordén 1991). 
Similar to the stand deposition, the canopy exchange rates of the investigated forest plots differed among the diversity levels (exceptions being $\mathrm{Al}^{3+}, \mathrm{NH}_{4}{ }^{+}$and $\mathrm{NO}_{3}{ }^{-}$); for the ions $\mathrm{Cl}^{-}$, $\mathrm{K}^{+}, \mathrm{Ca}^{2+}, \mathrm{H}^{+}$and $\mathrm{Mn}^{2+}$ canopy exchange rates were also related to the Shannon index. Most of the investigated ions were leached from the canopies; only $\mathrm{NH}_{4}{ }^{+}$and in mixed species plots $\mathrm{H}^{+}$ions were taken up by the canopy. $\mathrm{Na}^{+}$was assumed to be neither leached from nor taken up by the trees. The leaching of $\mathrm{Cl}^{-}, \mathrm{K}^{+}, \mathrm{Ca}^{2+}, \mathrm{Mg}^{2+}, \mathrm{PO}_{4}{ }^{3-}$ and $\mathrm{SO}_{4}{ }^{2-}$ increased, whereas the leaching of the soil acidifying ions $\mathrm{Mn}^{2+}$ and $\mathrm{H}^{+}$decreased with increasing diversity level. The pronounced leaching of $\mathrm{Mn}^{2+}$ in the pure beech plots is an indication that the soil properties of the plots were not the same. The mobility and plant availability of $\mathrm{Mn}^{2+}$ is greater under acidic soil conditions (Tyler 1976). If the concentration of soluble $\mathrm{Mn}^{2+}$ increases in the soil water, the tree roots probably take up more $\mathrm{Mn}^{2+}$, leading to higher leaf contents and canopy leaching rates. The soils of pure beech plots were indeed more acidic than those of the mixed species plots (Guckland et al. 2009), and the quantity of $\mathrm{Mn}^{2+}$ in both the soil (Guckland et al. 2009) and the soil solution (unpublished data) was highest in pure beech plots.

The different soil properties may also explain the differences in leaching of $\mathrm{K}^{+}, \mathrm{Ca}^{2+}$ and $\mathrm{Mg}^{2+}$. The soils of pure beech plots have lower effective cation exchange capacity and base saturation than those of mixed species plots (see Table 4.1) (Guckland et al. 2009). Hence, the trees can take up more $\mathrm{K}^{+}, \mathrm{Ca}^{2+}$ and $\mathrm{Mg}^{2+}$ in mixed species plots than in pure beech plots, and this, in turn, results in higher leaf concentrations of these ions (Jacob 2009) and in higher leaching rates (Nordén 1991). Similarly, the higher leaching rates of $\mathrm{PO}_{4}{ }^{3-}$ in the mixed species than in the pure beech plots may be explained by the different soil properties. Indeed, the mixed species plots have larger soil phosphorus pools (Talkner et al. 2009). The canopy leaching of $\mathrm{PO}_{4}{ }^{3-}$ made up $25 \%$ (DL1) to $67 \%$ (DL3) of the stand deposition. Due to negligible amounts of phosphorus in the ambient air and precipitation, canopy leaching can contribute up to $90 \%$ of $\mathrm{PO}_{4}{ }^{3-}$ in stand deposition (Parker 1983).

Differences in soil properties probably influenced the previous management practices, which led to pure beech stands in areas with low $\mathrm{BS}, \mathrm{CEC}_{\mathrm{e}}$ and $\mathrm{pH}$. This in turn resulted in a further decrease in $\mathrm{pH}$ and possibly also in $\mathrm{BS}$ and $\mathrm{CEC}_{\mathrm{e}}$ in the pure beech stands due to the soil acidifying properties of beech (Nordén 1994; Finzi et al. 1998; Neirynck et al. 2000; HagenThorn et al. 2004) and the lower decay rates of beech litter compared to ash and lime litter (Melillo et al. 1982). The results of Guckland et al. (2009) suggest that species-related differences in the intensity of the cation cycling between soil and tree contributed to the 
observed differences in soil acidification and BS among the studied forest plots. Hence, the tree species may have contributed to the differences in soil properties.

Differences in the physiology and ion status among the tree species may account for the observed differences in canopy exchange rates. Krauß and Heinsdorf (2005) showed that tree species differ in their leaf ion concentrations, independently of the soil properties. The investigated beech trees tended to have lower concentrations of $\mathrm{K}^{+}, \mathrm{Ca}^{2+}, \mathrm{Mg}^{2+}$ and $\mathrm{PO}_{4}{ }^{3-}-\mathrm{P}$ in their green leaves than the other deciduous tree species studied (Jacob 2009). This may have contributed to the lower canopy leaching rates of these ions in the pure beech plots. It is important to mention that the concentrations of $\mathrm{Ca}^{2+}, \mathrm{Mg}^{2+}$ and $\mathrm{N}_{\mathrm{t}}$ in the green leaves of the investigated beech trees did not differ between the diversity levels, and that the concentration of $\mathrm{K}^{+}$was lowest in DL2 plots and that of $\mathrm{PO}_{4}{ }^{3-}-\mathrm{P}$ highest in pure beech plots (Jacob 2009). Hence, the differences in soil properties are not reflected by the ion concentrations in green leaves in beeches. This is a confirmation of the species-specific differences in ion concentrations found by Krauß and Heinsdorf (2005) and emphasizes that the soil properties do not solely influence the ion status of trees. In addition, in a common garden test with 14 tree species including $T$. cordata, A. pseudoplatanus, A. platanoides, $F$. sylvatica and $C$. betulus, tree species influenced soil properties directly through variation in the quantity and chemistry of their litter and indirectly through the effect of their litter on detritivores (Reich et al. 2005). These effects led to rapid (within three decades) and widespread changes of soil properties beneath the different tree species (Reich et al. 2005).

The calculated acid input to the canopy was highest in pure beech plots, whereas the acid buffering capacity of the canopy did not differ between the diversity levels. Hence, the higher base saturation of the soils and the additional tree species in the mixed species plots did not lead to a higher canopy buffering capacity than in the pure beech plots. It is important to bear in mind that $\mathrm{H}^{+}$buffering in the canopy removes acidity from stand precipitation, but does not decrease the total $\mathrm{H}^{+}$input into the soil. This is because buffering in the canopy occurs by cation exchange from inner leaf tissue surfaces and these cation exchange buffer sites are recharged by cations taken up by the roots through exchange with protons in the rhizosphere of the soil (Ulrich 1983b).

In summary, we can state that the leaching of the cations $\mathrm{K}^{+}, \mathrm{Ca}^{2+}, \mathrm{Mg}^{2+}$ and the anions $\mathrm{Cl}^{-}$, $\mathrm{PO}_{4}{ }^{3-}$ and $\mathrm{SO}_{4}{ }^{2-}$ increased along the investigated tree species diversity gradient from monospecific beech plots to tree species-rich plots. The leaching of these ions not only differed between pure beech and mixed species plots but also between the mixed species plots 
(DL2 and DL3). In contrast, the canopy leaching of the soil acidifying ions $\mathrm{Mn}^{2+}$ and $\mathrm{H}^{+}$ decreased along the investigated tree species diversity gradient from monospecific beech plots to tree species-rich plots (with $\mathrm{H}^{+}$being taken up in mixed species plots). In this case, the difference was most pronounced between pure beech plots and mixed species plots, while mixed species plots did not differ. Pure beech and mixed species plots differed significantly in soil properties, whilst the mixed species plots (DL2 and DL3) had similar soil properties. Thus, the canopy exchange of $\mathrm{Mn}^{2+}$ and $\mathrm{H}^{+}$may mainly have been influenced by the differences in soil properties, whereas the leaching of $\mathrm{K}^{+}, \mathrm{Ca}^{2+}, \mathrm{Mg}^{2+}, \mathrm{Cl}^{-}, \mathrm{PO}_{4}{ }^{3-}$ and $\mathrm{SO}_{4}{ }^{2-}$ may also have been influenced by the physiology and ion status of the tree species present in the investigated forest plots.

\subsection{CONCLUSION}

The results of this observational study showed that atmospheric deposition was influenced by the stand composition (i.e., Shannon index). However, it was not possible to isolate the role of single stand characteristics such as stand height and canopy roughness, since they were closely correlated. One can assume that this is normally the case in most natural forest ecosystems. Canopy exchange processes were influenced by differences in ion status between the tree species as well as soil properties. Soil properties that influence canopy exchange processes are $\mathrm{pH}$, cation exchange capacity and base saturation. Trees influence these properties and beech trees in particular can lower $\mathrm{pH}$, base saturation, and cation exchange capacity. Hence, in addition to their direct influence on deposition and canopy exchange processes, the tree species also have an indirect effect by altering the above-mentioned soil properties, which, in turn, affects the uptake of ions by the trees and the subsequent canopy exchange.

\subsection{ACKNOWLEDGEMENT}

This study was funded by the German Research Council (DFG) within the Research Training Group 1086 ('The role of biodiversity for biogeochemical cycles and biotic interactions in temperate deciduous forests'). We thank our colleagues from the Research Training Group for providing us with stand characteristic data, Birgit Köhler for reviewing the manuscript, two 
anonymous reviewers for their valuable comments and suggestions and Ingrid Rosenfelder for improving the language of the manuscript.

\subsection{REFERENCES}

André F, Jonard M, Ponette Q. 2008. Spatial and temporal patterns of throughfall chemistry within a temperate mixed oak-beech stand. Science of the Total Environment 397: 215228.

Baumgarten M, von Teuffel K. 2005. Nachhaltige Waldwirtschaft in Deutschland. In: von Teuffel K, Baumgarten M, Hanewinkel M, Konold W, Sauter UH, Spiecker H, von Wilpert K (eds) Waldumbau. Springer, Berlin, pp 1-10.

Beier C, Gundersen P, Rasmussen L. 1992. A new method for estimation of dry deposition of particles based on throughfall measurements. Atmospheric Environment 26a: 1553-1559.

Berger TW, Untersteiner H, Schume H, Jost G. 2008. Throughfall fluxes in a secondary spruce (Picea abies), a beech (Fagus sylvatica) and a mixed spruce-beech stand. Forest Ecology and Management 255: 605-618.

Boynton D. 1954. Nutrition by foliar application. Annual Review of Plant Physiology 5: 3154.

Bredemeier M. 1988. Forest canopy transformation of atmospheric deposition. Water, Air, and Soil Pollution 40: 121-138.

Cape JN, Leith ID. 2002. The contribution of dry deposited ammonia and sulphur dioxide to the composition of precipitation from continuously open gauges. Atmospheric Environment 36: 5983-5992

Chiwa M, Crossley A, Sheppard LJ, Sakugawa H, Cape JN. 2004. Throughfall chemistry and canopy interactions in a Sitka spruce plantation sprayed with six different simulated polluted mist treatments. Environmental Pollution 127: 57-64.

Croisé L, Ulrich E, Duplat P, Jaquet O. 2005. Two independent methods for mapping bulk deposition in France. Atmospheric Environment 39: 3923-3941.

de Vries W, and 13 others. 2001. Intensive monitoring of forest ecosystems in Europe. Technical Report 2000, UN/ECE, EC, Forest Intensive Monitoring Coordinate Institute, Heerenveen.

Draaijers GPJ, van Ek R, Meijers R. 1992. Research on the impact of forest stand structure on atmospheric deposition. Environmental Pollution 75: 243-249. 
Draaijers GPJ, Erisman JW, van Leeuwen NFM, Römer FG, te Winkel BH, Vermeulen AT, Wyers GP, Hansen K. 1994. A comparison of methods to estimate canopy exchange at the Speulder Forest. National Institute of Public Health and Environmental Protection, Bilthoven, Report No. 722108004.

Draaijers GPJ, Erisman JW. 1995. A canopy budget model to assess atmospheric deposition from throughfall measurements. Water, Air, and Soil Pollution 85: 2253-2258.

Draaijers GPJ, Erisman JW, van Leeuwen NFM, Römer FG, te Winkel BH, Veltkamp AC, Vermeulen AT, Wyers GP. 1997. The impact of canopy exchange on differences observed between atmospheric deposition and throughfall fluxes. Atmospheric Environment 31: 387-397.

Elling W, Heber U, Polle A, Beese F. 2007. Schädigung von Waldökosystemen. Elsevier, München.

Erisman JW, Draaijers G. 2003. Deposition to forests in Europe: Most important factors influencing dry deposition and models used for generalization. Environmental Pollution 124: $379-388$.

FAO. 1998. FAO, ISRIC, ISSS World reference base for soil resources. World Soil Resources Reports 84, Rome.

Finzi AC, Canham CD, van Breemen N. 1998. Canopy tree-soil interactions within temperate forests: Species effects on $\mathrm{pH}$ and cations. Ecological Applications 8: 447-454.

Gaige E, Dail D, Hollinger D, Davidson E, Fernandez I, Sievering H, White A, Halteman W. 2007. Changes in canopy processes following whole-forest canopy nitrogen fertilization of a mature spruce-hemlock forest. Ecosystems 10: 1133-1147.

Georgii HW. 1986. Atmospheric pollutants in forest areas. D Reidel Publishing Company, Dordrecht.

Godt J. 1986. Untersuchung von Prozessen im Kronenraum von Waldökosystemen. Berichte des Forschungszentrums Waldökosysteme/Waldsterben, Band 17, Göttingen.

Guckland A, Jacob M, Flessa H, Thomas FM, Leuschner C. 2009. Acidity, nutrient stocks and organic matter content in soils of a temperate deciduous forest with different abundance of European beech (Fagus sylvatica L.). Journal of Plant Nutrition and Soil Science 172: 500-511.

Hagen-Thorn A, Callesen I, Armolaitis K, Nihlgård B. 2004. The impact of six European tree species on the chemistry of mineral topsoil in forest plantations on former agricultural land. Forest Ecology and Management 195: 373-384. 
Jacob M. 2009. Productivity and nutrient relations of trees in deciduous forests with contrasting tree species diversity. Dissertation, University of Goettingen.

Jacob M, Leuschner C, Thomas FM. 2010. Productivity of temperate broad-leaved forest stands differing in tree species diversity. Annals of Forest Science 67: 503.

Johnson DW, Lindberg SE. 1992. Atmospheric deposition and forest nutrient cycling. Ecological Studies 91, Springer, New York.

Knoke T, Stimm B, Ammer C, Moog M. 2005. Mixed forests reconsidered: A forest economics contribution on an ecological concept. Forest Ecology and Management 213: $102-116$.

Krämer I, Hölscher D. 2009. Rainfall partitioning along a tree diversity gradient in a deciduous old-growth forest in Central Germany. Ecohydrology 2: 102-114.

Krauß HH, Heinsdorf D. 2005. Ernährungsstufen für wichtige Wirtschaftsbaumarten. Beiträge für Forstwirtschaft und Landschaftsökologie 39: 172-179.

Leuschner C, Jungkunst HF, Fleck S. 2009. Functional role of forest diversity: pros and cons of synthetic stands and across-site comparisons in established forests. Basic and Applied Ecology 10: 1-9.

Lindberg SE, Lovett GM, Richter DD, Johnson DW. 1986. Atmospheric deposition and canopy interactions of major ions in a forest. Science 231: 141-145.

Lovett GM, Lindberg SE. 1984. Dry deposition and canopy exchange in a mixed oak forest as determined by analysis of throughfall. Journal of Applied Ecology 21: 1013-1027.

Lovett GM, Nolan SS, Driscoll CT, Fahey TJ. 1996. Factors regulating throughfall flux in a New Hampshire forested landscape. Canadian Journal of Forest Research 26: 2134-2144.

Magurran AE. 2004. Measuring biological diversity. Blackwell Science, Oxford.

Matzner E. 1986. Deposition/Canopy-interactions in two forest ecosystems of northwest Germany. In: Georgii HW (ed) Atmospheric Pollutants in Forest Areas. D Reidel Publishing Company, Dordrecht, pp 247-262.

Matzner E, Meiwes KJ. 1994. Atmospheric pollutants - Long-term development of element fluxes with bulk precipitation and throughfall in two German forests. Journal of Environmental Quality 23: 162-166.

Mayer R. 1983. Interaction of forest canopies with atmospheric constituents: Aluminum and heavy metals. In: Ulrich B, Pankrath J (eds) Effects of accumulation of air pollutants in forest ecosystems. D Reidel Publishing Company, Dordrecht, pp 47-55. 
Meesenburg H, Meiwes KJ, Rademacher P. 1995. Long term trends in atmospheric deposition and seepage output in northwest German forest ecosystems. Water, Air, and Soil Pollution 85: 611-616.

Meesenburg H, Eichhorn J, Meiwes KJ. 2009. Atmospheric deposition and canopy interaction. In: Brumme R, Khanna PK (eds) Functioning and management of European beech ecosystems. Springer, New York.

Melillo JM, Aber JD, Muratore JF. 1982. Nitrogen and lignin control of hardwood leaf litter decomposition dynamics. Ecology 63: 621-626.

Neirynck J, Mirtcheva S, Sioen G, Lust N. 2000. Impact of Tilia platyphyllos Scop., Fraxinus excelsior L., Acer pseudoplatanus L., Quercus robur L. and Fagus sylvatica L. on earthworm biomass and physico-chemical properties of a loamy topsoil. Forest Ecology and Management 133: 275-286.

Nordén U. 1991. Acid deposition and throughfall fluxes of elements as related to tree species in deciduous forests of South Sweden. Water, Air, and Soil Pollution 60: 209-230.

Nordén U. 1994. Influence of tree species on acidification and mineral pools in deciduous forest soils of south Sweden. Water, Air, and Soil Pollution 76: 363-381.

Parker GG. 1983. Throughfall and stemflow in the forest nutrient cycle. Advanced Ecological Research 13: 57-133.

Potter CS, Ragsdale HL, Swank WT. 1991. Atmospheric deposition and foliar leaching in a regenerating southern appalachian forest canopy. Journal of Ecology 79: 97-115.

R Development Core Team. 2007. R: A language and environment for statistical computing. R Foundation for Statistical Computing, Vienna.

Reich PB, Oleksyn J, Modrzynski J, Mrozinski P, Hobbie SE, Eissenstat DM, Chorover J, Chadwick OA, Hale CM, Tjoelker MG. 2005. Linking litter calcium, earthworms and soil properties: A common garden test with 14 tree species. Ecology Letters 8: 811-818.

Roelofs JGM, Kempers AJ, Houdijk ALFM, Jansen J. 1985. The effect of air-borne ammonium sulphate on Pinus nigra var. maritima in the Netherlands. Plant and Soil 84: $45-56$.

Schmidt I, Leuschner C, Mölder A, Schmidt W. 2009. Structure and composition of the seed bank in monospecific and tree species-rich temperate broad-leaved forests. Forest Ecology and Management 257: 695-702.

Shannon CE, Weaver W. 1949. The mathematical theory of communication. University of Illinois Press, Urbana. 
Stachurski A, Zimka JR. 2002. Atmospheric deposition and ionic interactions within a beech canopy in the Karkonosze Mountains. Environmental Pollution 118: 75-87.

Staelens J, de Schrijver A, Verheyen K. 2007. Seasonal variation in throughfall and stemflow chemistry beneath a European beech (Fagus sylvatica L.) tree in relation to canopy phenology. Canadian Journal of Forest Research 37: 1359-1372.

Staelens J, Houle D, de Schrijver A, Neirynck J, Verheyen K. 2008. Calculating dry deposition and canopy exchange with the canopy budget model: Review of assumptions and application to two deciduous forests. Water, Air, and Soil Pollution 191: 149-169.

Swank WT. 1984. Atmospheric contributions to forest nutrient cycling. Water Resources Bulletin 20: 313-321.

Talkner U, Jansen M, Beese FO. 2009. Soil phosphorus status and turnover in centralEuropean beech forest ecosystems with differing tree species diversity. European Journal of Soil Science 60: 338-346.

Tyler G. 1976. Soil factors controlling metal ion absorption in the wood anemone Anemone nemorosa. Oikos 27: 71-80.

UBA (Umweltbundesamt). 2006. Konzentrationen von $\mathrm{SO}_{2}, \mathrm{NO}_{2}, \mathrm{O}_{3}$ und $\mathrm{PM}_{10}$ aus dem Luftmessnetz des Umweltbundesamtes. UBA, Dessau-Roßlau. www. umweltbundesamt.de/luft/luftmessnetze/mb2006/mb0606.pdf, last visited: 02.03.2010.

Ulrich B. 1983a. Interaction of forest canopies with atmospheric constituents: $\mathrm{SO}_{2}$, Alkali and earth alkali cations and chloride. In: B Ulrich, J Pankrath (eds) Effects of accumulation of air pollutants in forest ecosystems. D Reidel Publishing Company, Dordrecht, pp 33-45.

Ulrich B. 1983b. A concept of forest ecosystem stability and of acid deposition as driving force for destabilization. In: Ulrich B, Pankrath J (eds) Effects of accumulation of air pollutants in forest ecosystems. D Reidel Publishing Company, Dordrecht, pp 1-29.

Ulrich B. 1994. Nutrient and acid-base budget of central European forest ecosystems. In: Godbold DL, Hüttermann A (eds) Effects of acid rain on forest processes. Wiley-Liss, pp $1-50$.

Ulrich B, Pankrath J. 1983. Effects of accumulation of air pollutants in forest ecosystems. D Reidel Publishing Company, Dordrecht.

Ulrich KU, Paul L, Meybohm A. 2006. Response of drinking-water reservoir ecosystems to decreased acidic atmospheric deposition in SE Germany: Trends of chemical reversal. Environmental Pollution 141: 42-53.

Wulf M. 2003. Preference of plant species for woodlands with differing habitat continuities. Flora 198: 444-460. 


\section{CHAPTER}

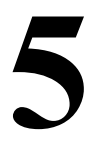

\section{Modeling stand water budgets of mixed temperate broad- leaved forest stands by considering variations in species- specific drought response}

Sebastian Bittner, Ulrike Talkner, Inga Krämer, Friedrich Beese, Dirk Hölscher, Eckart Priesack

(published in Aricultural and Forest Meteorology 150: 1347-1357)

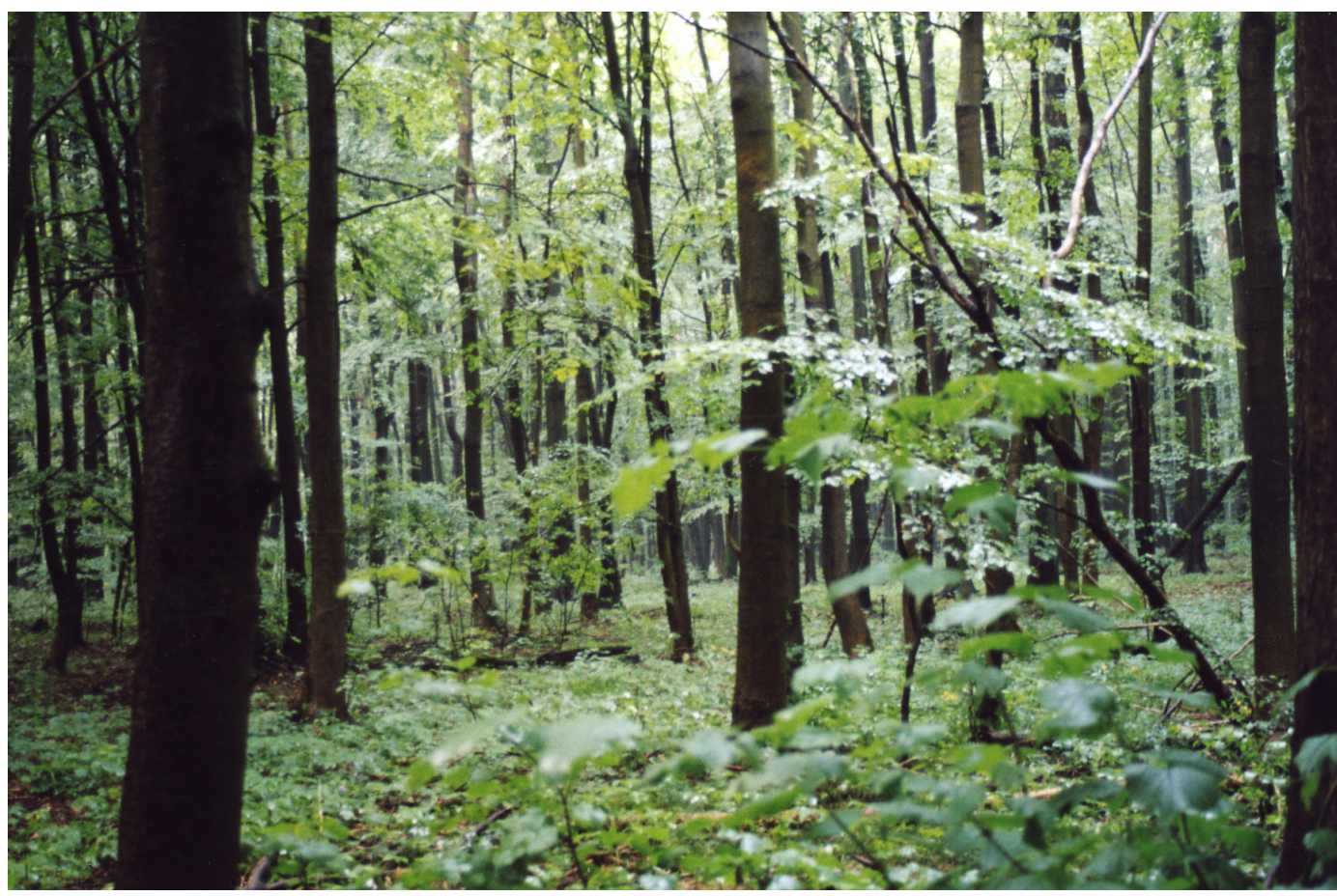




\subsection{ABSTRACT}

This modeling study used recent observations at a temperate broad-leaved forest in Central Germany to calculate water balances of a Fagus sylvatica monoculture and mixed stands of Fagus sylvatica, Tilia spp., Acer spp., Carpinus betulus, Fraxinus excelsior and Quercus robur.

To simulate soil water flow the modeling framework Expert-N was applied which combines models that describe the physiological and hydrological processes of the plant-soil system including models of evapotranspiration (Penman-Monteith equation), interception (revised Gash model) and soil water flow (Richards equation). Measurements of rainfall partitioning, volumetric soil water content, evapotranspiration and tree transpiration provided reliable data for the parameterization and the calibration of the model for three stands of different diversity levels. They allowed to include species specific physiological (transpiration rates, response to dry soil water conditions) and structural (leaf area dynamics) characteristics.

During the three year long observation period 2005 to 2007 the mean yearly precipitation was $652 \mathrm{~mm}$, the simulated mean yearly interception loss of the three observed forest stands was between $219 \mathrm{~mm}$ and $272 \mathrm{~mm}$, the transpiration accounted for 197 to $225 \mathrm{~mm}$, the forest floor evaporation for 96 to $104 \mathrm{~mm}$, the drainage for 16 to $60 \mathrm{~mm}$ and the runoff for 13 to $50 \mathrm{~mm}$. The calculations of the water balance were sensitive to the species composition of the forest and showed differences of rainfall interception and root water uptake between the stands. The applied stand-level model was able to simulate the water dynamics of the monospecific and mixed forest stands. It was shown that differences in drought tolerance of tree species can have a strong impact on the simulated soil water extraction during periods when available soil water is low.

\subsection{INTRODUCTION}

Forest structure and tree species composition have a strong influence on the water storage, retention of water and groundwater recharge in forest ecosystems (FAO, 2005; Calder 2007; van Dijk and Keenan, 2007). Stand water dynamics are mainly determined by the functional traits of the different tree species present in the stand. The rainfall partitioning and evapotranspiration of broad-leaved tree species of Central European forests are reviewed in (Peck, 2004). It is shown that in particular observations of different tree species under similar meteorological conditions are rare and that broad-leaved tree species of Central European 
forests other than beech (Fagus sylvatica L.) have been less investigated with respect to rainfall partitioning and water uptake. One of these rare studies analyses the differences of the direct throughfall caused by different broad-leaved tree species compositions in a mixed forest stand in southern Sweden (Nordén, 1991). The throughfall was lowest for beech, followed by Norway maple (Acer platanoides L.), small leaved lime (Tilia cordata Mill.), hornbeam (Carpinus betulus L.), and common oak (Quercus robur L.) in ascending order. Sap flux studies in mixed stands have revealed differences in whole-tree water turnover among co-occurring tree species (Granier et al., 1996; Dünisch and Morais, 2002; Pataki and Oren, 2003) and in the reaction of the species to dry soil water conditions (Pataki et al., 2000; Oishi et al., 2010). In a mixed forest in Denmark, ash (Fraxinus excelsior L.) had half as much stemflow as beech (Dalsgaard, 2007). Moreover, different timing of leafing and leaf shedding could lead to differences in interception and water uptake during spring and autumn. For example, higher throughfall is likely to occur under ash, as ash is known to get into leaves relatively late in spring.

Recent observations in a deciduous old-growth forest in Central Germany (Hainich National Park) showed differences between tree species with respect to water use and their impact on water flows. The species European beech, lime (Tilia cordata and T. platyphyllos Scop.), ash, hornbeam, and sycamore (Acer pseudoplatanus L.) were found to differ in physiological characteristics such as root water uptake (Korn, 2004), transpiration rates (Hölscher et al., 2005; Köcher et al., 2009; Gebauer, 2010) and reaction to dry soil conditions (Hölscher et al., 2005; Köcher et al., 2009). Information on the stands composed of these species was also provided by hydrological measurements such as rainfall partitioning (Krämer and Hölscher, 2009) and soil water content dynamics (Krämer and Hölscher, in press). Characteristics of the stand structure were given by observations of the fine root distribution (Meinen, 2008; Meinen et al., 2009) and leaf area index (LAI) dynamics.

Therefore, the aim of our study was to simulate the observed water balance dynamics of the Hainich stands applying a functional stand-level model by using the available information on the species specific functional traits and hydrologic stand characteristics and thereby to characterize the input of different tree species on the water balance dynamic. In a first step the model was calibrated and tested for three stands with similar soil and climatic conditions but with a different diversity level (DL) of tree species. One stand was a monoculture of beech trees and two stands were mixed stands of beech and other broad-leaved deciduous tree species. 
Secondly a subsequent scenario analysis was performed to study the impact of the species composition on the water balance and in particular to analyse the effect of different root water uptake and different tree species specific reactions to dry soil water conditions. We expect this analysis to allow conclusions about how mixed stands react to changed climatic conditions and how species composition itself affects the stability and function of the whole stands under conditions of low soil water availability.

\subsection{MATERIAL AND METHODS}

\section{Stand-level models}

We applied the modeling framework Expert-N (Engel and Priesack, 1993; Priesack et al., 2001; Stenger et al., 1999) for the management of the input data (meteorological data, soil properties, physiological parameters) and for the coupling of single process models. The considered processes were rainfall interception, forest floor evaporation, transpiration, and soil water fluxes and the applied models included the FAO Penman-Monteith evapotranspiration model (Monteith, 1965; Monteith, 1981; Allen et al., 1998), the revised Gash interception model (Gash et al., 1995) and the description of soil water flows by the Richards equation of porous media.

Model input parameters can be divided into two groups. Mean values of the stand can be derived by measuring a certain system variable (e.g., soil water content) at different positions in the stand and taking the mean of all measured values. Examples in this study were measured values of rainfall partitioning, volumetric soil water contents, and the leaf area index of the fully developed canopy. Tree species specific parameters (e.g., reaction to dry soil conditions) are weighted by the proportion of the tree species in the stand. For $n$ different tree species with a property expressed by the parameter $p_{i}(i \in 1 \ldots n)$ and the species proportion $c_{i}$, the property of the whole stand $p_{s}$ is calculated as a linear combination $p_{s}=\sum_{i=1}^{n} c_{i} p_{i}$. The water stress factor due to dry soil conditions and the transpiration rates of the tree species were examples of this weighted mean in this study.

All model approaches are described in detail below as well as the measurements that provided the data for the parameterization and testing of the models. 


\section{Study site}

The study site was located in a deciduous forest in the Hainich National Park (Thuringia, Germany. $51^{\circ} \mathrm{N}, 10^{\circ} \mathrm{E}$, national park founded in 1997). European beech is the dominant tree species in large areas of the National Park, but up to 14 tree species coexist in some parts as a consequence of former management practice (Schmidt et al., 2009). In the last decades minimal forest management took place due to the military training status of the area since the 1960s. Since 1990 the site has not been managed at all, therefore the forest has a near-natural state. The selected plots represent old-growth forest stands with a closed canopy. The subatlantic climatic conditions of the plots can be considered to be the same with respect to daily temperatures, precipitation, global radiation, humidity and wind speed.

Parent rock is Triassic limestone covered with a loess layer of variable depth. The soil type is a Luvisol that dries out strongly during summer and shows stagnant properties in winter and spring (Guckland et al., 2009). The soil texture of all plots was characterized by high silt content and low sand content (silt loam to silt clay loam, Table 5.1). The groundwater table is found far below the rooting zone.

\section{Study plots}

In the forest area three study plots of $50 \mathrm{~m} \times 50 \mathrm{~m}$ size each were selected. The maximum distance between two plots was $1.5 \mathrm{~km}$. The plots were situated at 296-354 m a. s. 1., slopes ranged between $2.9^{\circ}$ and $3.2^{\circ}$ and exposition of all plots was northeast. One monospecific stand with Fagus sylvatica and two mixed stands with a variable mixture of broad-leaved deciduous species (Fagus sylvatica, Tilia cordata, T. platyphyllos, Fraxinus excelsior, Carpinus betulus, Acer pseudoplatanus, A. campestre, A. platanoides and Quercus robur) were analyzed. The fraction of the dominating tree species was calculated by the projected crown area. The stand age of each of the three plots was between 79 and 117 years (Schmidt et al., 2009), the mean crown diameter was between 4.6 and $5.2 \mathrm{~m}$. The canopy closure during summer was on average $87 \%$ (Krämer and Hölscher, 2009) and the mean leaf area index was 6.9 (Jacob et al., 2010). All stand details are based on trees with a diameter at breast height $(\mathrm{dbh})>7 \mathrm{~cm}$. Main stand characteristics are presented in Table 5.2. 
Table 5.1 Soil properties and soil hydraulic parameters. $\Delta z$ depth interval, $\rho_{b}$ soil bulk density, $\theta_{s}$ saturated vol. water content, $\theta_{r}$ residual vol. water content, $n$ van Genuchten parameter, $\alpha$ van Genuchten parameter, $K_{S}$ saturated hydraulic conductivity.

\begin{tabular}{ccccccccccc}
\hline \multirow{2}{*}{ Plot } & $\Delta z$ & sand & silt & clay & $\rho_{b}$ & $\theta_{s}$ & $\theta_{r}$ & $n$ & $\alpha$ & $K_{S}$ \\
$\%$ & $\%$ & $\%$ & $\%$ & $\mathrm{~cm}^{-3}$ & $\%$ & $\%$ & 1 & $\mathrm{~cm}^{-1}$ & mm day \\
\hline DL1a & $0-10$ & 4.2 & 78.3 & 17.5 & 0.89 & 55 & 6 & 1.336 & 0.023 & 1150 \\
& $10-20$ & 3.3 & 82.3 & 14.4 & 1.09 & 50 & 6 & 1.357 & 0.016 & 770 \\
& $20-30$ & 3.6 & 79.6 & 16.8 & 1.42 & 40 & 7 & 1.276 & 0.017 & 220 \\
& $30-40$ & 3.6 & 78.4 & 18.0 & 1.37 & 40 & 8 & 1.283 & 0.018 & 280 \\
& $40-60$ & 1.9 & 65.3 & 32.8 & 1.57 & 38 & 11 & 1.200 & 0.018 & 50 \\
& $60-80$ & 1.9 & 65.3 & 32.8 & 1.65 & 38 & 7 & 1.240 & 0.011 & 25 \\
& $80-100$ & 2.0 & 58.0 & 40.0 & 1.62 & 41 & 15 & 1.200 & 0.070 & 15 \\
\hline DL2c & $0-10$ & 2.2 & 82.0 & 15.0 & 1.23 & 51 & 6 & 1.374 & 0.014 & 540 \\
& $10-20$ & 2.8 & 82.4 & 14.8 & 1.45 & 46 & 6 & 1.346 & 0.011 & 220 \\
& $20-30$ & 3.4 & 81.2 & 15.2 & 1.59 & 41 & 8 & 1.241 & 0.033 & 210 \\
& $30-40$ & 4.7 & 80.2 & 15.2 & 1.49 & 41 & 7 & 1.218 & 0.032 & 110 \\
& $40-60$ & 1.8 & 57.0 & 41.2 & 1.62 & 40 & 9 & 1.216 & 0.036 & 25 \\
& $60-80$ & 2.0 & 58.0 & 40.0 & 1.60 & 40 & 16 & 1.247 & 0.066 & 25 \\
& $80-100$ & 2.0 & 58.0 & 40.0 & 1.63 & 41 & 11 & 1.161 & 0.055 & 20 \\
\hline DL3a & $0-10$ & 2.6 & 74.6 & 22.8 & 1.05 & 52 & 9 & 1.314 & 0.037 & 675 \\
& $10-20$ & 2.1 & 75.9 & 22.0 & 1.18 & 49 & 9 & 1.299 & 0.032 & 505 \\
& $20-30$ & 2.1 & 74.3 & 23.6 & 1.37 & 48 & 12 & 1.294 & 0.045 & 500 \\
& $30-40$ & 1.8 & 66.6 & 31.6 & 1.54 & 45 & 9 & 1.202 & 0.035 & 70 \\
& $40-60$ & 2.1 & 59.5 & 38.4 & 1.44 & 45 & 17 & 1.394 & 0.091 & 70 \\
\hline
\end{tabular}

Table 5.2 Forest stands characteristics of the three study plots. 'lime': Tilia cordata and T. platyphyllos, LAI: leaf area index. Trees $>7 \mathrm{~cm}$ dbh.

\begin{tabular}{|c|c|c|c|c|c|c|c|c|}
\hline \multirow[b]{3}{*}{ Plot } & \multicolumn{3}{|c|}{${ }^{\mathrm{a}} \mathrm{LAI}$} & \multicolumn{5}{|c|}{ Share of crown projection area } \\
\hline & 2005 & 2006 & 2007 & \multirow{2}{*}{$\begin{array}{r}\text { Beech } \\
\%\end{array}$} & \multirow{2}{*}{$\begin{array}{r}\text { Lime } \\
\%\end{array}$} & \multirow{2}{*}{$\begin{array}{c}\text { Ash } \\
\%\end{array}$} & \multirow{2}{*}{$\begin{array}{c}\text { Hornbeam } \\
\%\end{array}$} & \multirow{2}{*}{$\begin{array}{c}\text { Sycamore } \\
\%\end{array}$} \\
\hline & & $\mathrm{m}^{2} / \mathrm{m}^{2}$ & & & & & & \\
\hline DL1a & 6.5 & 7.3 & 7.2 & 94 & 2 & 2 & 0 & 2 \\
\hline DL2c & 6.6 & 6.5 & 6.2 & 73 & 14 & 10 & 0 & 1 \\
\hline DL3a & 7.3 & 7.6 & 6.5 & 7 & 55 & 9 & 14 & 2 \\
\hline
\end{tabular}

${ }^{\mathrm{a}} \mathrm{M}$. Jacob, personal communication, calculated from leaf biomass collected in litter traps 
The thickness of the loess cover was heterogeneous and varied between 60 and $120 \mathrm{~cm}$ (Guckland et al., 2009) at the three study plots. Soil texture in the upper mineral soil (0$30 \mathrm{~cm})$ of the tree plots was characterized by high silt content $(74-82 \%)$ and low sand content $(<5 \%)$. The clay content varied between $14-23 \%$ at a soil depth of $0-30 \mathrm{~cm}, 15-32 \%$ at a depth of $30-40 \mathrm{~cm}$ and $33-41 \%$ at a depth of 40-60 cm (Table 5.1) depending on the depth of the illuvial Bt horizon. The mean values of the soil bulk densities were $1.1 \mathrm{~g} \mathrm{~cm}^{-3}$ at $0-10 \mathrm{~cm}$ and increased with depth to $1.5 \mathrm{~g} \mathrm{~cm}^{-3}$ at $40-60 \mathrm{~cm}$.

The plot names follow the classification given by Leuschner et al. (2009). Overall, twelve study plots were set up and plots with similar Shannon tree diversity indices were grouped in the three diversity levels DL1, DL2 and DL3. Additionally they were assigned in preceding studies with letters a-d. For the possibility to look up the plot characteristics in cited studies, we used the same names (DL1a, DL2c and DL3a) in this study. Leuschner et al. (2009) give a detailed description of the study site and the forest biodiversity research activity in the Hainich National Park.

\section{Precipitation}

The mean annual precipitation of four stations around the national park amounts to 544 to $662 \mathrm{~mm}$ (annual mean from 1961-1990 (DWD, 2009)). During the observation period 2005 to 2007 the precipitation was automatically recorded every hour at the meteorological station Weberstedt/Hainich (270 m a. s. $1 ., 51^{\circ} 10^{\prime} \mathrm{N}, 10^{\circ} 52^{\prime}$ E, Meteomedia, Germany). The yearly precipitation amount and the rainfall in the vegetation period differed significantly in the three observed years. The year 2005 had a typical amount of precipitation (601 mm) compared to the long-term annual mean precipitation. The year 2006 was relatively dry $(518 \mathrm{~mm})$ and 2007 was a year with a high amount of precipitation $(838 \mathrm{~mm})$. The year 2006 had a long drought period with only $28 \mathrm{~mm}$ precipitation from June 1 st to July 27 th. The precipitation in the vegetation period (May-October) was $318 \mathrm{~mm}$ in 2005, $239 \mathrm{~mm}$ in 2006 and $537 \mathrm{~mm}$ in 2007. The precipitation values for the dry year $2003(388 \mathrm{~mm})$ that were used in the scenario simulations in chap. 3.3 were measured by CarboEurope (2009).

\section{Soil hydraulic parameters and volumetric soil water content}

The soil water flow simulations implemented in Expert-N are based on the numerical solution of the 1D Richards equation according to the approach applied in the model HYDRUS 6.0 (Šimunek et al., 1998). The water retention curves were expressed by the van Genuchten 
parametrization (van Genuchten, 1980). We used the software Rosetta Version 1.2 (Schaap et al., 2001) for the estimation of the saturated volumetric water content $\theta_{s}$, the residual volumetric water content $\theta_{r}$, the saturated hydraulic conductivity $K_{S}$ and the van Genuchten parameters $\alpha$ and $n$. Rosetta needs the soil texture, soil bulk density $\rho_{b}$ (Table 5.1) and measured volumetric water contents at a pressure of 33 and $1500 \mathrm{kPa}$ as input data for each soil horizon.

Soil texture was determined using the sieving and pipette method (Schlichting et al., 1995). In 0-10 $\mathrm{cm}$ soil depth the texture analysis was performed at three sampling points per stand. In $10-20 \mathrm{~cm}, 20-30 \mathrm{~cm}, 30-40 \mathrm{~cm}$, and $40-60 \mathrm{~cm}$ soil depth it was performed at single soil samples taken from soil profile pits adjacent to the plots. In deeper soil layers the textual class was estimated and tabulated values of the clay, silt and sand content were used. At the plot DL3a the soil was parameterized to the depth of the loess layer that was just $60 \mathrm{~cm}$ at that plot. Soil bulk density was determined gravimetrically from three undisturbed soil cores $\left(125 \mathrm{~cm}^{3}\right)$ taken from the adjacent soil-profile pits. The volumetric water contents at a pressure of 33 and $1500 \mathrm{kPa}$ were determined on five undisturbed $250 \mathrm{~cm}^{3}$ soil cores per sampling depth from the soil pits adjacent to the stands, with a suction membrane in the lower suction range $(33 \mathrm{kPa})$ and a pressure membrane device in the higher suction range $(1500 \mathrm{kPa})$.

At the three study plots the volumetric soil water content $\theta_{V}$ was measured using frequency domain reflectometry (FDR) probes (Diviner 2000 FDR sensors, Sentek Pty Ltd., Stepney, Australia) at six locations per study plot (Krämer and Hölscher, in press). The probe measures the dielectric constant across $a \approx 10 \mathrm{~cm}$ sphere of influence surrounding the sensor and at $10 \mathrm{~cm}$ depth intervals to a depth of $40 \mathrm{~cm}$. The FDR probe was depth-specifically calibrated in the field (Krämer and Hölscher, in press) as suggested and described by the manufacturer.

\section{Interception}

The rainfall interception was simulated using the revised Gash model (Gash et al., 1995) on daily basis and on event basis. The daily-basis model assumes the daily precipitation to occur at a single storm. The event basis model uses hourly precipitation amounts and assumes that two single rain events are separated by a period without precipitation during which the canopy dries. The duration of the dry period was assumed to be at least one hour according to our observations at the Hainich forest. 
The Gash model needs the fraction $p$ of rain which falls directly to the forest floor (free throughfall) as input parameter. To determine this parameter, the gap fraction $g$ in summer and the branch cover in winter were determined by hemispherical photographs (Krämer and Hölscher, 2009). The hemispherical photographs were taken vertically upward above each rain gauge (for the measurement of the throughfall, see below). The camera (Minolta Dimage Xt, Japan) had a $185^{\circ}$ fish-eye lens. Images were analyzed for gap fraction in a $10^{\circ}$ circular area directly above the gauges with CanEye 5.0 (INRA, 2009).

Additionally, the interception capacity $S(\mathrm{~mm})$ of the canopy and the mean canopy evaporation rate per mean rainfall rate $\bar{E}_{C} / \bar{R}$ are needed as input for the Gash model. We estimated these parameters using measured throughfall $T F$ and gross precipitation $P$ for single rain events during the observation period. For observed single rain events with neglectable stemflow amounts, interception $I$ can be set to $I=P-T F$. A scatter plot $I(P)$ can be divided into a wetting part and a saturated part and be used for the mean method estimation of the Gash parameters (Klaassen et al., 1998). A linear regression of $I(P)$ for rain events high enough to saturate the canopy results in estimates for $\bar{E}_{C} / \bar{R}$ and $S_{\text {mean }}$ (mm), the mean water storage capacity by using

$I=S_{\text {mean }}+\frac{\bar{E}_{C}}{\bar{R}} P$.

The interception capacity $S$ is then given by

$$
S=-\frac{\bar{E}_{C}}{\bar{R}} S_{\text {mean }}\left[\left(1-p-\frac{\bar{E}_{C}}{\bar{R}}\right) \ln \left(1-\frac{\bar{E}_{C} / \bar{R}}{1-p}\right)\right]^{-1},
$$

if $\left(\bar{E}_{C} / \bar{R}-p\right)<1$.

The calibration of the interception model was tested by using measurements from the whole period 2005-2007 for which the partitioning of gross rainfall $P$ into interception $I$, throughfall $T F$ and stemflow $S F$ has been measured (Krämer and Hölscher, 2009).

\section{Potential evapotranspiration}

The potential evapotranspiration $E T_{\text {pot }}$ was calculated by the FAO Penman-Monteith equation (Monteith, 1965; Monteith, 1981; Allen et al., 1998), which estimates the daily $E T_{p o t}$ for a hypothetical grass reference surface. The partitioning of $E T_{p o t}$ into the potential transpiration of the forest canopy and potential evaporation of the forest floor was achieved by a plant cover factor and the leaf area index $\left(L A I, \mathrm{~m}^{2} \mathrm{~m}^{-2}\right)$ of the trees. To this, the $L A I$ of the 
plots was calculated from leaf biomass collected in litter traps (Jacob et al., 2010). The physiological development of the leaves in spring and autumn was interpolated such that the $L A I$ increases from 0 to the measured value for the fully foliated canopy following a sigmoidal function of time in spring and decreased in the same way in autumn. We included species specific dates of spring leafing and shedding in fall according to measurements of transpiration rates (T. Gebauer, personal communication) and direct observations.

The daily $E T_{p o t}$ was partitioned into the daily potential transpiration $T_{p o t}$ and daily potential forest floor evaporation $E_{p o t}$ by a cover factor $f$ (Droogers, 2000)

$$
\begin{aligned}
& T_{p o t}=f E T_{p o t} \\
& E_{p o t}=(1-f) E T_{p o t} .
\end{aligned}
$$

\section{Actual forest floor evaporation and root water uptake}

The actual forest floor evaporation $E_{a c t}$ was simulated by limiting $E_{p o t}$ by the calculated maximal water flux $q_{\max }\left(\mathrm{mm} \mathrm{day}^{-1}\right)$ at time $t$ (day) from the top soil segment (Hutson and Wagenet, 1992). $E_{\text {act }}$ is then given by

$$
E_{a c t}=\min \left(E_{p o t}, q_{\max } \Delta t\right) .
$$

The actual transpiration $T_{a c t}$ was calculated under consideration of the soil water availability and the vertical distribution of fine roots in the soil. At the depth $z$ the root water uptake is proportional to the density $g(z)$ and to the reduction factor $r(h)$ that depends on the soil matric potential $h$ (Perrochet, 1987; Lai and Katul, 2000). This factor includes the special edaphic situation with clay-rich soils that restrict root water uptake by low soil hydraulic conductivities and the species specific physiological reaction to dry soil conditions. The total actual transpiration was calculated by integrating the root water uptake over the depth of the rooting zone $L$,

$$
T_{a c t}=T_{p o t} \int_{o}^{L} g(z) r(h) d z
$$

Note that the constraints $\int_{o}^{L} g(z) d z=1, \int_{0}^{L} r(h) d z \leq 1$ and $\int_{o}^{L} g(z) r(h) d z \leq 1$ have to be met.

A non-linear vertical cumulative root distribution (Gale and Grigal, 1987) was used to describe the decrease of the fine root biomass with increasing soil depth. The cumulative root biomass fraction $y(l)$ from the surface to depth $l$ is determined by 
$y(l)=\int_{0}^{l} g(z) d z=1-\beta^{l}$,

using the parameter $\beta$ which describes if the roots are mostly located in deeper soil layers or if they are distributed mostly near the surface and assuming a simple relation to describe the vertical root density distribution $g(z)$. The vertical fine root distribution in the soil was determined by taking soil samples down to a depth of $40 \mathrm{~cm}$ and measuring the biomass of fine roots with a diameter less than 2 mm (Meinen, 2008; Meinen et al., 2009).

The simulated values of $T_{a c t}$ were then compared with the values of $T_{a c t}$ that have been calculated from measurements of xylem sap flux density in the tree stem observed by Gebauer (2010) using Granier heat dissipation sensors (Granier, 1985; Granier, 1987) installed on 44 trees with dbh $>10 \mathrm{~cm}$ on the plots DL1a, DL2c and DL3a in the years 2005 and 2006.

At the nearby Hainich site of the CarboEurope (2009) research project the latent heat flux above the canopy was measured half hourly by the eddy covariance method and the evaporation was calculated using these measurements.

\subsection{RESULTS AND DISCUSSION}

\section{Parameterization}

\section{Interception}

To parameterize the Gash model values of the gap fraction, the canopy storage capacity and the mean canopy evaporation rate to rainfall rate ratio are needed. The measured gap fraction of the canopy in summer was $0.11-0.16$ for the three plots (Table 5.3) and the branch cover in winter was 0.11-0.13. The low rainfall intensities in winter (Krämer and Hölscher, 2009) and the fact that the measured interception loss in winter was about $30 \%$ and nearly as high as in summer indicated that the small rain drops of winter rain events mostly could not pass the defoliated canopy freely. Therefore, also for the defoliated canopy in winter we assumed $p$ to be equal to the measured gap fraction of the canopy in summer (foliated canopy). The estimated parameters of $\bar{E}_{C} / \bar{R}$ and $S$ for the foliated and the defoliated canopy for the observation periods are given in Table 5.3, the linear regression of $I(P)$ for the foliated plot DL1a is given in Figure 5.1. 
Table 5.3 Gash interception model parameters free throughfall $p$, mean canopy evaporation rate per mean rainfall rate $\bar{E}_{C} / \bar{R}$ and interception capacity $S$.

\begin{tabular}{cccc}
\hline Plot & $p$ & $\bar{E}_{C} / \bar{R}$ & $S[\mathrm{~mm}]$ \\
\hline foliated & & & \\
DL1a & 0.11 & $0.22 \pm 0.06$ & $1.02 \pm 0.36$ \\
DL2c & 0.12 & $0.22 \pm 0.05$ & $1.35 \pm 0.43$ \\
DL3a & 0.16 & $0.21 \pm 0.04$ & $0.45 \pm 0.30$ \\
\hline defoliated & & & \\
DL1a & 0.11 & $0.16 \pm 0.09$ & $0.94 \pm 0.41$ \\
DL2c & 0.12 & $0.21 \pm 0.11$ & $0.70 \pm 0.60$ \\
DL3a & 0.16 & $0.23 \pm 0.11$ & $0.59 \pm 0.53$ \\
\hline
\end{tabular}

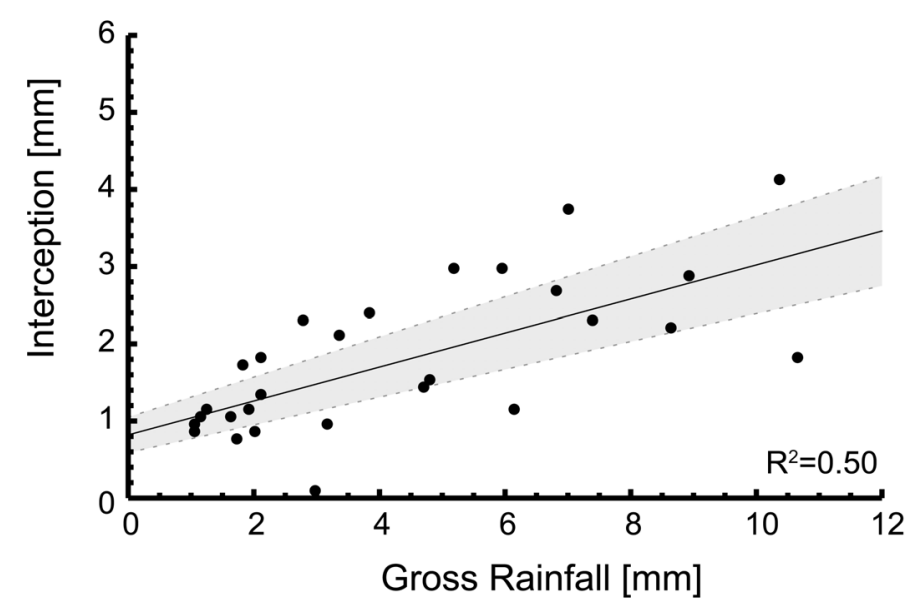

Figure 5.1 Measured values of gross rainfall and interception for the parameterization of the Gash model of the foliated plot DL1a. The mean canopy evaporation rate per mean rainfall rate $\bar{E}_{C} / \bar{R}$ and $S_{\text {mean }}$ are given by the slope and the y-intercept. The shadowed area shows the uncertainty range of the parameters.

\section{Transpiration and forest floor evaporation}

In the winter period $\left(\mathrm{T}_{\mathrm{act}}=0\right)$ we could calibrate the cover factor to $f=0.7$, such that the simulated soil water contents $\theta_{V}$ matched the measured values. The factor was the same for all plots during the leafless period. In the foliated period $f$ was increased in the model due to the additional coverage of the forest floor by the foliation of tree canopies. This additional coverage was calculated for periods of fully developed $L A I$ using the difference between the measured canopy cover in summer $(1-g$, gap fraction $g$ ) and in winter (branch cover). In 
spring and fall the $L A I$ dynamics of the different tree species were used to calculate the additional coverage of the forest soil. The values of $L A I$ in summer varied between 6.2 and $7.6 \mathrm{~m}^{2} \mathrm{~m}^{-2}$ between the study plots and years (M. Jacob, personal communication; Table 5.2).

\section{Root density distribution}

Data on root biomass distribution by Meinen et al. (2009) were used to parameterize the model. The fine root biomass decreased markedly with soil depth and the vertical distribution was similar between the three stands. Therefore also the values of $\beta$ which were determined by the observed root distribution were similar in the different stands and varied between 0.93 and 0.94. In all plots about half of the total fine root biomass was found in the first $15 \mathrm{~cm}$ of the profile and more than $85 \%$ of the fine root biomass in the first $40 \mathrm{~cm}$ according to an extrapolation of the root distribution model.

The fine root biomass distribution was also determined for the single tree species. The fine root biomass proportion of the single tree species in the mixed stands reflected the aboveground proportion of the particular tree species in the stand. The differences in vertical root distribution were low with $\beta$ between 0.91 for Acer spp. on DL2 and 0.94 for Fagus sylvatica. For simplicity, we did not distinguish the vertical root distribution of the single tree species in the model. We also assumed the understory to have the same composition of trees as the stand with full canopy height.

Grass and herb roots were distinguished from tree roots by their smaller diameter, nonlignified structure and lighter color. The contribution of herb roots to the total root biomass in the profile was marginal (1\% in DL1a and DL2c; $4 \%$ in DL3a).

\section{Root water uptake reduction factor}

At optimal wet soil water conditions the water uptake reduction factor $r\left(h_{\text {opt }}\right)$ was estimated by comparing the measured and simulated values of $T_{a c t}$ and $\theta_{V}$. Because the measured transpiration of the three sites was low (maximal measured yearly value: $158 \mathrm{~mm}$ ) compared with other deciduous forests (Gebauer, 2010) the factor was set $r\left(h_{\text {opt }}\right) \leq 0.5$. A reason for the observed low transpiration could be the low unsaturated hydraulic conductivity of the clayrich soils, which limit the water flow to the roots. Gebauer (2010) measured the sap flux density of five tree species and observed that at optimal wet soil water conditions the contribution of the different tree species to total stand transpiration did not reflect the proportion of the accordant species in the canopy. The transpiration rates of the ring-porous 
species $F$. excelsior were significantly lower than the rates of the diffuse-porous species $F$. sylvatica, Tilia spp., Acer spp. and C. betulus. This could be explained by the small hydroactive sapwood area of $F$. excelsior with only the youngest annual rings being involved in water transport (Gebauer et al., 2008). In our model, the differences of the species in root water uptake were parameterized according to the studies of Gebauer (2010) and Hölscher et al. (2005). The reduction factor of the diffuse-porous species was set to 0.5 for optimal soil water conditions in the model. The factor of the ring-porous species $F$. excelsior was set to 0.25 .

At dry soil water conditions, the water uptake was further decreased to account for the stomatal reaction of the trees. Several stand level forest models consider the reaction of trees to water stress and describe the effect on the total water balance (Sen et al., 2000; Mitchell, 2005; Fischer et al., 2008). We assume a linear decrease of water uptake at dry soil conditions (Figure 5.2, Table 5.4), as this behaviour was observed for the tree species at the Hainich forest (Hölscher et al., 2005; Köcher et al., 2009).

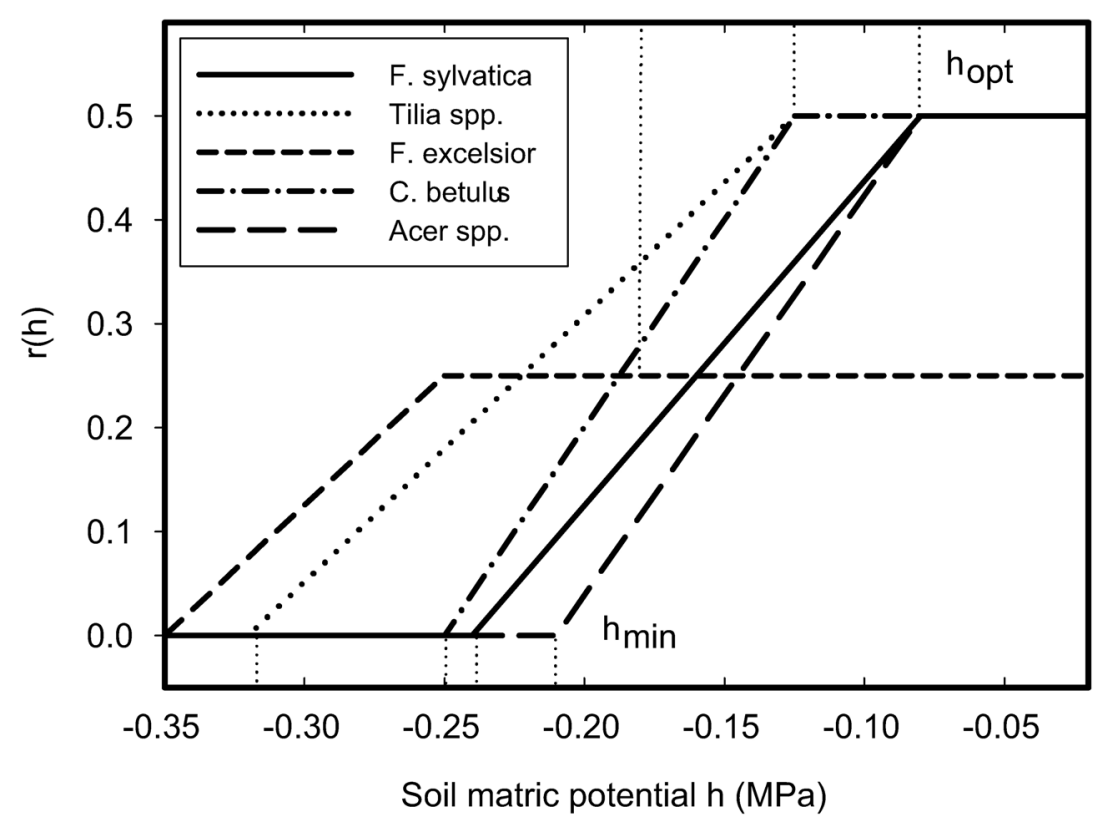

Figure 5.2 Root water uptake at optimal wet soil conditions $\left(h>h_{\text {opt }}\right)$ and reaction to water stress $\left(h<h_{\text {opt }}\right)$. Root water uptake is reduced by the factor $r(h)$. 
Table 5.4 Species specific parameters of transpiration, reaction to water stress due to dry soil water conditions, and leaf development. The root water uptake decreases lineary with a soil matric potential lower than $h_{\text {opt }}$. At a soil matric potential of $h<h_{\min }$ the trees are not able to take up water from the soil. The reduction factor of transpiration rate at optimal wet soil conditions is given by $r\left(h_{o p t}\right)$.

\begin{tabular}{lcccc}
\hline \multicolumn{1}{c}{ Species } & $r\left(h_{\text {opt }}\right)$ & $h_{\text {opt }}$ & $h_{\min }$ & Foliated period \\
& 1 & $M P a$ & $M P a$ & \\
\hline Fagus sylvatica & 0.5 & -0.08 & -0.24 & $05 / 01-10 / 31$ \\
Tilia spp. & 0.5 & -0.13 & -0.32 & $05 / 08-10 / 25$ \\
Fraxinus excelsior & 0.25 & -0.25 & -0.35 & $05 / 15-10 / 15$ \\
Carpinus betulus & 0.5 & -0.13 & -0.25 & $05 / 15-10 / 15$ \\
Acer spp. & 0.5 & -0.08 & -0.21 & $05 / 15-10 / 15$ \\
\hline
\end{tabular}

According to the root water uptake model of Feddes et al. (1987), the root water uptake decreases linearly when the soil matric potential $h$ is lower than the matric potential $h_{\text {opt }}$ of an optimal wet soil. For values $h>h_{\text {opt }}$ the water uptake reaches a constant maximum value. At a soil matric potential of $h<h_{\min }$ the trees are not able to take up water from the soil. The reduction factor $r(h)$ can be interpreted as a water stress factor. F. sylvatica and Acer spp. respond sensitively to soil drought and show a strong reduction of water uptake. Tilia spp. is less sensitive to drought conditions and $F$. excelsior can deal best with dry soil conditions. No reduction of water uptake of F. excelsior was observed during a dry period in the study of Hölscher et al. (2005) and during the observation period of the study by Köcher et al. (2009). In contrast to the model of Feddes et al. (1987), our model parameterization did not include a decrease of the water uptake due to anaerobic conditions at very wet soil conditions.

Herbst et al. (2007) pointed out that ash shows a heterogeneous radial pattern of the sap flux density and proposed a specific calibration function for the sap flux sensors for ash. This specific calibration function would result in a higher sap flux density and thus in higher transpiration rates than the ones obtained by the commonly used calibration function. Thus the absolute values of transpiration for ash have to be regarded with caution, but the behaviour of ash at dry soil conditions remains unaffected. This uncertainty in the model calibration has a low impact on the simulated total transpiration values of the three plots, because of the low percentage of ash in the plots, but may affect the simulated values of transpiration of the scenario calculations.

Moreover, three dimensional modeling of the root architecture and the root water uptake might lead to a more complex one-dimensional water uptake reduction function (Javaux et al., 
2008). A further analysis of the three-dimensional architecture of the root system therefore may lead to an improved and more realistic one-dimensional water uptake reduction function.

\section{Simulation}

\section{Interception}

The measured interception loss was between 21 and $41 \%$ of the gross precipitation and differences between seasons were more pronounced than between plots (Krämer and Hölscher, 2009). The measured stemflow played a minor role at all three stands and was between 0.4 and $6.2 \%$ of the gross precipitation.

The simulated values of interception were compared with the measured values in Figure 5.3 for two summer periods and one winter period. The periods were defined according to the observed physiological development of the trees and represent periods fully foliated and fully defoliated canopies. The largest deviation between simulation and measurement could be observed in summer 2007 at the plot DLla, where the measured value was $26 \mathrm{~mm}(22 \%)$ lower than the simulated value. For all other observation periods and plots the deviation between simulation and measurement was below $10 \%$. These differences are comparable to other studies that use the revised Gash model to simulate the rainfall interception of mixed stands (Price and Carlyle-Moses, 2003; Deguchi et al., 2006). The simulated interception values were also compared with the difference of measured gross precipitation and measured values of throughfall for rainfall events with no observed stemflow $(P<2 \mathrm{~mm}, I=P-T F$, Figure 5.4). For single events with higher $P$, an estimation of the measured interception was not possible, as the stemflow for single events was not measured.

If more than one rainfall event per day occurs, the use of the Gash model at event basis can lead to higher values of rainfall interception than the model based on the daily basis. But using the model at event basis can also lead to lower interception values because rainfall events that occur over midnight are separated by the daily basis model but not by the event basis model. The difference between the simulation at daily basis in contrast to the event basis was rather low (4-11\%) for the summer period. In winter, the simulated interception showed significantly higher (16-18\%) values if calculated at event basis than at daily basis and matched the measured values better. An explanation is the low rainfall intensity in winter (Krämer and Hölscher, 2009), as the single events in winter had lower amounts of rain than the summer events and in winter usually more than one event occurred per day. Therefore, we 
used the Gash model on event basis for the subsequent simulation and analysis of the soil water flow and plant water uptake.

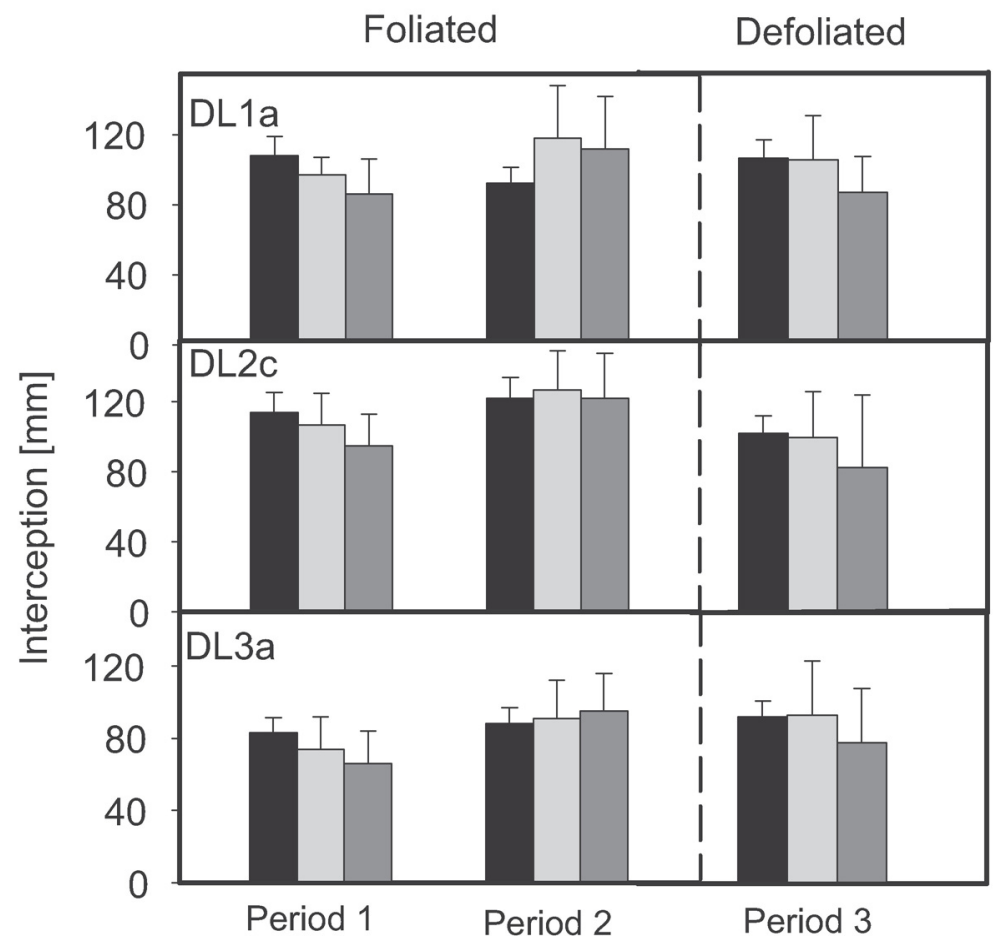

Figure 5.3 Measured (black) and simulated (light gray: event basis; dark gray: daily basis) interception loss $(\mathrm{mm})$ during three observation periods. Period 1: 5/19/2006-9/6/2006, period 2: 5/17/2007-8/22/2007, period 3: 12/2/2006-4/5/2007. The error bars indicate the measurement error and the model uncertainty due to the uncertainty of the parameters $S$ and $\bar{E}_{C} / \bar{R}$.
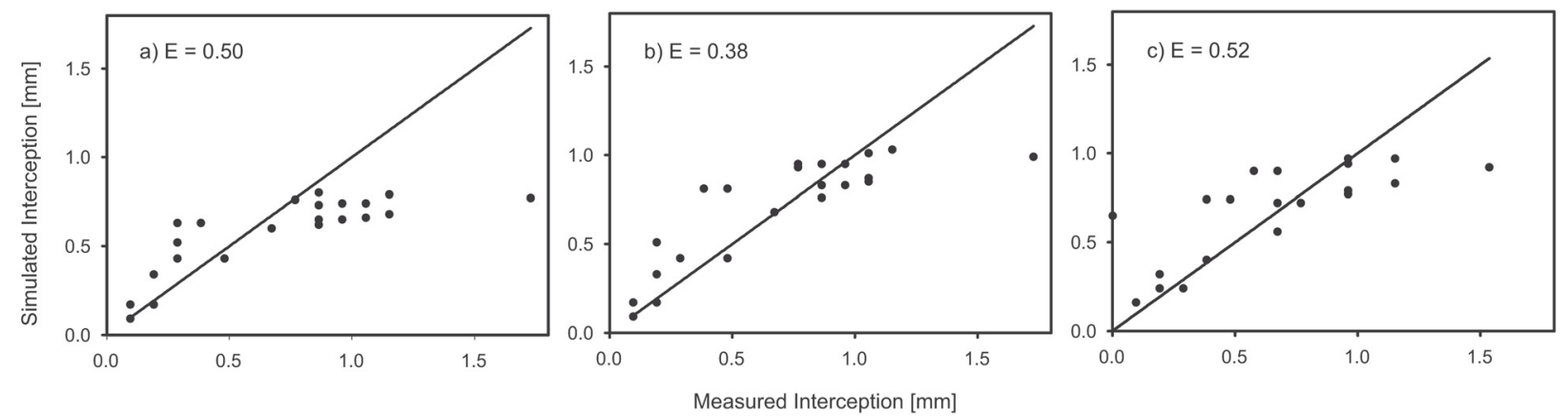

Figure 5.4 Measured and simulated interception of single rainfall events for the plots DL1a (a), DL2c (b) and DL3a (c). Model efficiency E (Nash-Sutcliffe Index), solid line: measured = simulated. 
It was not possible to extract the parameters of the Gash model for the single tree species, because the number of analysed plots was too low to derive the values by statistical methods. By using the observations at twelve plots at the Hainich National Park (Krämer and Hölscher, 2009), it was also not possible to extract the influence of single tree species on the interception. In this study Krämer and Hölscher (2009) found a positive correlation of direct throughfall and a negative correlation of the stemflow with the diversity level but no significant correlation between the diversity level of the plots and the interception loss. It was also stated (Krämer and Hölscher, 2009) that the rainfall partitioning was strongly influenced by stand structural characteristics such as stand height, crown length, and crown roughness. The higher measured and simulated interception loss of the plot DL2c in comparison with the other two plots (Table 5.5) may be seen as an effect of non species specific stand structure (i.e. stem density) rather than stand species composition.

Table 5.5 Simulated yearly water balances of the years 2005-2007 at the three study plots. $T_{o b s}$ contains the observed values of transpiration by trees with $\mathrm{dbh}>10 \mathrm{~cm}$ (Gebauer, 2010), $T$ is the simulated total tree transpiration, all values in $\mathrm{mm}$.

\begin{tabular}{llccccrrr}
\hline Year & Plot & $T_{\text {obs }}$ & \multicolumn{1}{c}{$T$} & \multicolumn{1}{c}{$E$} & \multicolumn{1}{c}{$D$} & \multicolumn{1}{c}{$R$} & \multicolumn{1}{c}{$\Delta S$} \\
\hline 2005 & DL1a & 101 & 233 & 93 & 236 & 31 & 2 & 5 \\
$(P=601)$ & DL2c & 97 & 199 & 97 & 267 & 5 & 19 & 12 \\
& DL3a & 158 & 224 & 104 & 213 & 25 & 18 & 17 \\
\hline 2006 & DL1a & 134 & 208 & 91 & 223 & 17 & 3 & -24 \\
$(P=518)$ & DL2c & 139 & 174 & 95 & 256 & 4 & 17 & -27 \\
& DL3a & 128 & 205 & 97 & 204 & 16 & 25 & -29 \\
\hline 2007 & DL1a & - & 234 & 102 & 259 & 133 & 36 & 73 \\
$(P=838)$ & DL2c & - & 217 & 106 & 292 & 40 & 97 & 84 \\
& DL3a & - & 217 & 112 & 238 & 107 & 106 & 57 \\
\hline
\end{tabular}

$P$, Precipitation; $E$, forest floor evaporation, $I$, Interception; $D$, Drainage; $R$, Runoff; $\Delta S$, Change in soil water storage.

\section{Transpiration and forest floor evaporation}

The simulated yearly values of the sum of forest floor evaporation $E$ and transpiration $T$ (Table 5.5) ranged from $269 \mathrm{~mm}$ to $336 \mathrm{~mm}$, the differences were higher between the years than between the different plots. The values were low compared with those of other forests (Granier et al., 2000; Wullschleger et al., 2001; Schipka et al., 2005; Vincke et al., 2005b; 
Wullschleger and Hanson, 2006), but similar to the values of evapotranspiration measured by the CarboEurope project at a beech site with similar soil properties and similar stand age located near to our study sites (2005: $270 \mathrm{~mm}, 2006: 280 \mathrm{~mm}, 2007: 350 \mathrm{~mm}$; CarboEurope, 2009).

The forest floor evaporation showed the highest values in April and May, when the leaves of the trees were not fully developed and the potential evapotranspiration increased. For the total year, the ratio of $E$ to the total evapotranspiration $E /(E+T+I)$ was $0.17-0.19$. For the summer periods, the fraction was $0.10-0.13$. These values are similar to the values observed at deciduous forests with a LAI similar to our site by using lysimeter studies $(0.10-0.20$; Kelliher et al., 1992) or eddy flux measurements at the forest floor (0.10-0.11, Moore et al., 1996; 0.08, Wilson et al., 2001).

The biomass of the herb layer increased along the tree species diversity gradient (Mölder et al., 2008). Also the thickness of the litter layer depended on the diversity level of the plots and decreased with increasing tree species diversity (Mölder et al., 2008). Thus a model separation of forest floor evaporation into components such as herb-layer transpiration (Marin et al., 2000) and litter evaporation (Ogée and Brunet, 2002) might improve the description of biodiversity effects on the simulated water balance.

The simulated values of transpiration were $45-87 \mathrm{~mm}$ higher than the values obtained by sap flux measurements in the year 2006 (Table 5.5). The simulated values of water uptake must be interpreted as the transpiration of the total canopy, i.e. the trees with full canopy height plus the understory, as the model was calibrated to the measured volumetric soil water content. The differences may be explained by the contribution of the understory to the total transpiration. Also the herb layer can possibly extract high amounts of water from the soil as shown in cases of other forest types (Lüttschwager et al., 1999; Vincke et al., 2005a; Iida et al., 2009). Thus a more complex model of the forest floor that includes the competition between herbs and trees for soil water may lead to a lower value of the transpiration of the trees. A possible underestimation of the tree transpiration by the xylem flux method is also discussed in a study on the soil water extraction at the study site (Krämer and Hölscher, in press).

The measured yearly transpiration values for the two beech dominated plots DL1a and DL2c in 2005 were low $(\approx 100 \mathrm{~mm})$ in comparison with the third plot DL3a and the values of the year 2006. The model did not show lower values for these plots in the year 2005, the values were 199-233 mm for all the three plots. The plot DL3a had a large fraction of lime (55\%), 
but even by parameterizing higher values of $r\left(h_{o p t}\right), h_{\min }$, and $h_{\text {opt }}$ for lime the model could not reproduce the measured higher transpiration in 2005 in comparison with the beech dominated plots and maintain the lower transpiration in 2006 of the DL3a plot. Gebauer (2010) considers after-effects of the extreme drought in the year 2003 as one reason for the low transpiration values of the beech dominated plots DL1a and DL2c. Because our model did not quantify the damage of trees due to water stress, possible damages of the water stress sensitive Fagus sylvatica caused by the drought in 2003 may explain the high deviation between simulated and measured values in 2005 for the beech dominated plots DL1a and DL2c.

The daily values of simulated transpiration and the periods of water stress of the beech dominated DL1a stand are presented in Figure 5.5. The year 2006 had rainless periods in June, July and September. The daily modelled transpiration rates decreased rapidly in July and September as a reaction to dry soil water conditions. This decrease was also measured by Gebauer (2010). Therefore, the model was able to describe the decrease of water uptake under dry soil conditions. In the years 2005 and 2007 longer periods without rainfall did not occur during the vegetation period. A decrease of daily transpiration values could be observed only near the end of the vegetation period and can be explained by a lower atmospheric evaporative demand.
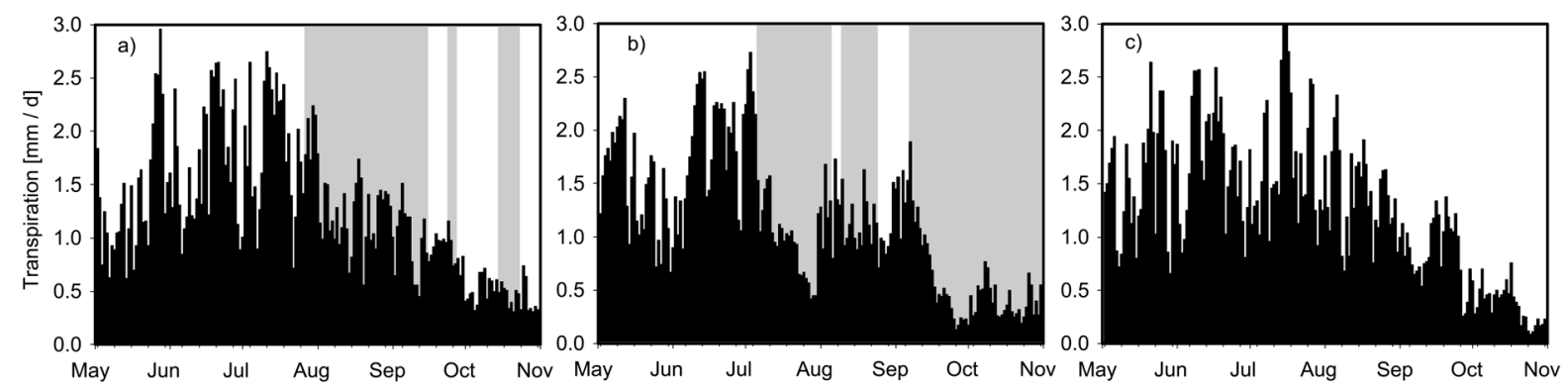

Figure 5.5 Simulated daily transpiration $(\mathrm{mm})$ at the beech dominated plot DL1a during the years 2005 (a), 2006 (b) and 2007 (c). The grey areas show the periods of water stress for F. sylvatica according to the water stress model.

The differently parameterized water uptake functions did not lead to strong differences between the simulated yearly transpiration rates of the three plots. One reason was the fact that the fraction of the only ring-porous species ash that was parameterized to have lower 
uptake rates at optimal soil water conditions was low at all three plots $(\leq 10 \%)$ and that different reactions of the tree species to water stress had an effect just within some weeks. One of these periods was July 2006, when the reduction of water uptake due to dry soil water conditions accounted for $20 \mathrm{~mm}$ at the plot DL1a which was $53 \%$ of the total water uptake of July 2006. At the plot DL2a the reduction was $19 \mathrm{~mm}$, at the plot DL3c the reduction accounted for $13 \mathrm{~mm}$. Moreover, the transpiration rates are a consequence of the overlay of the water uptake strategies with other factors such as soil water input and soil hydraulic characteristics.

At all three study plots, no indication of vertical segregation of the fine root system was observed (Meinen, 2008; Meinen et al., 2009), which indicates that a spatial complementary soil water use by the different species plays a minor role during most of the time.

\section{Soil water flow and water balances}

The measured values of the volumetric soil water content $\theta_{V}$ at soil depths of 10, 20, 30 and $40 \mathrm{~cm}$ in comparison with the simulated values at DL1a are shown in Figure 5.6. The simulation was in accordance with the measurement with respect to the maximum and minimum soil water conditions and the seasonal changes. The model mirrored the soil water conditions of the dry year 2006 with a long drought period in summer as well as the relative wet year 2007. The model efficiency and the root mean square error for all three simulated sites can be seen in Table 5.6. The quality is comparable to 1D-SVAT simulations of monoculture forest stands (Hoff et al., 2002; Christiansen et al., 2006; Schwärzel et al., 2007; Schwärzel et al., 2009; Christiansen et al., accepted).

The good match of simulated and measured volumetric soil water content at different depths indicates that the soil hydraulic properties are parameterized properly and that the simulated soil water fluxes are reasonable. The runoff and the drainage have not been measured but the simulated values are direct results of the soil water flow simulations and were also in a plausible range. Significant amounts of runoff and drainage occurred during the wet year 2007. During the dry year 2006 and during the year 2005 with usual mean rainfall the runoff values were lower than $5 \%$ of the yearly precipitation.

The difference of the water balance components between the three stands was low in all three years and mostly a consequence of the higher simulated interception loss at the plot DL2c (Table 5.5). This higher interception led to a lower input of soil water and lower rates of simulated evapotranspiration. Despite the large interannual variation in rainfall, the simulated 
annual evaporation and transpiration showed only small variation. On the one hand the tree species water uptake capability decreases during periods of dry soil conditions in years with low annual rainfall, but on the other hand the atmospheric water demand is lower in wet years with many rainy days which also decreases the transpiration rates. Small interannual variability of the evapotranspiration was also observed at a broad-leaved forest in North America (Oishi et al., 2010).

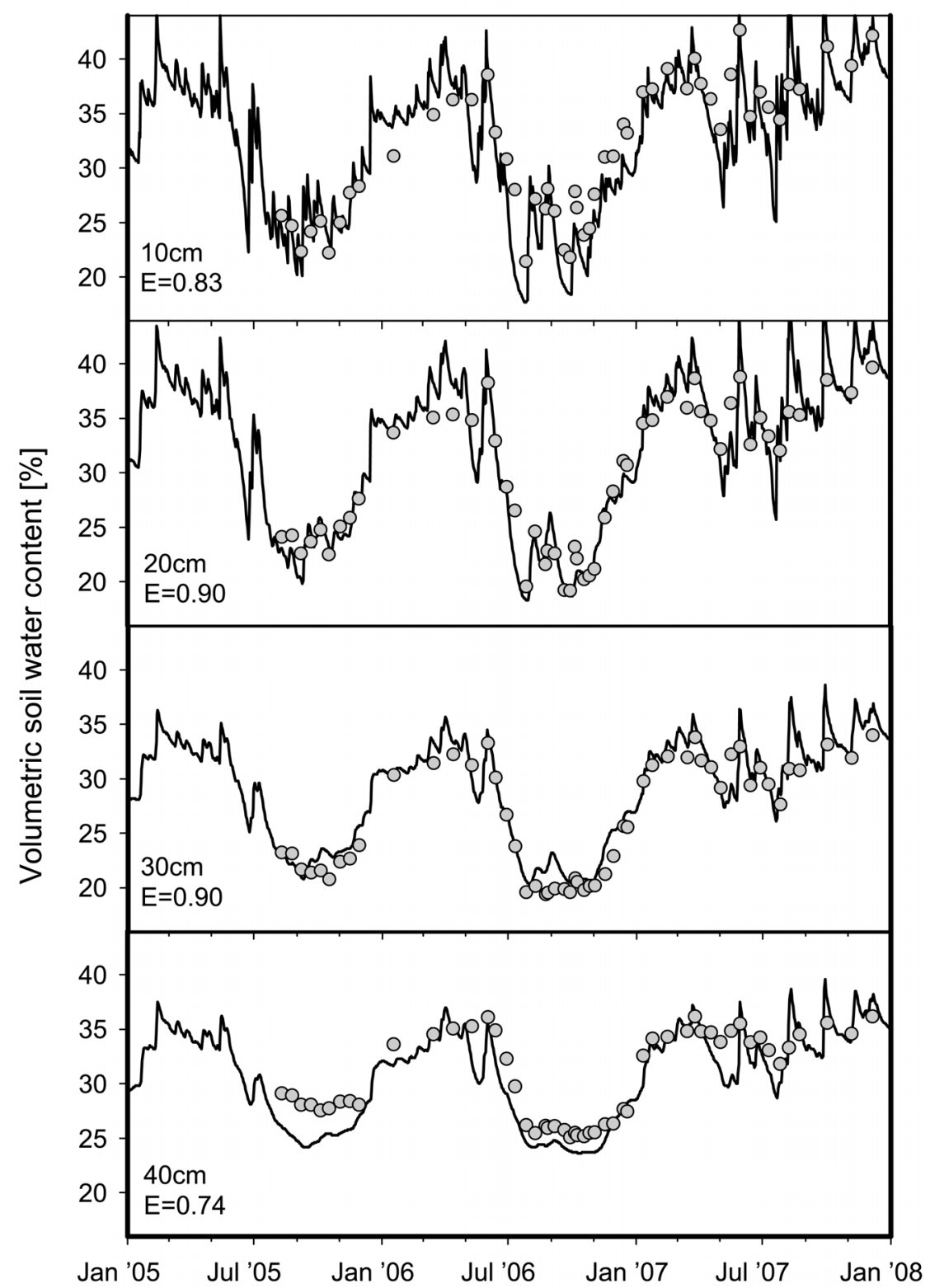

Figure 5.6 Measured (dots) and simulated (lines) volumetric soil water content at 10, 20, 30 and $40 \mathrm{~cm}$ soil depth at DL1a. 
Table 5.6 Model performance of soil water content simulations. E: Model efficiency (Nash-Sutcliffe index); RMSE: root mean square error.

\begin{tabular}{clcc}
\hline Site & Depth & E & RMSE [\%] \\
\hline DL1a & $10 \mathrm{~cm}$ & 0.83 & 2.5 \\
& $20 \mathrm{~cm}$ & 0.90 & 2.0 \\
& $30 \mathrm{~cm}$ & 0.90 & 1.6 \\
& $40 \mathrm{~cm}$ & 0.74 & 2.0 \\
\hline DL2c & $10 \mathrm{~cm}$ & 0.42 & 5.0 \\
& $20 \mathrm{~cm}$ & 0.80 & 2.8 \\
& $30 \mathrm{~cm}$ & 0.85 & 2.0 \\
& $40 \mathrm{~cm}$ & 0.56 & 3.3 \\
\hline DL3a & $10 \mathrm{~cm}$ & 0.73 & 4.2 \\
& $20 \mathrm{~cm}$ & 0.80 & 3.7 \\
& $30 \mathrm{~cm}$ & 0.69 & 3.1 \\
& $40 \mathrm{~cm}$ & 0.84 & 2.0 \\
\hline
\end{tabular}

\section{Scenario of species composition}

The actual water uptake was calculated for a scenario of different combinations of beech, lime and ash in mixed stands for the observed years 2005-2007 as well as for the very dry year 2003. We used the species specific water uptake functions (Figure 5.2) weighted by the proportion of the species in the stand scenario. All other model input parameters such as soil characteristics and rainfall interception parameters were not changed.

The calculations show large differences of simulated yearly transpiration between the stands of different species composition (Figure 5.7). This is due to the different water uptake rates of the species at optimal soil water conditions, as the diffuse-porous species lime and beech were parameterized to have twice as high transpiration rates than the ring-porous species ash at wet soil water conditions. In the wet year 2007 there was sufficient water available during the vegetation period and no water stress occurred such that the simulated differences between the transpiration rates are a direct result of the root water uptake parameterization at optimal soil water conditions. 

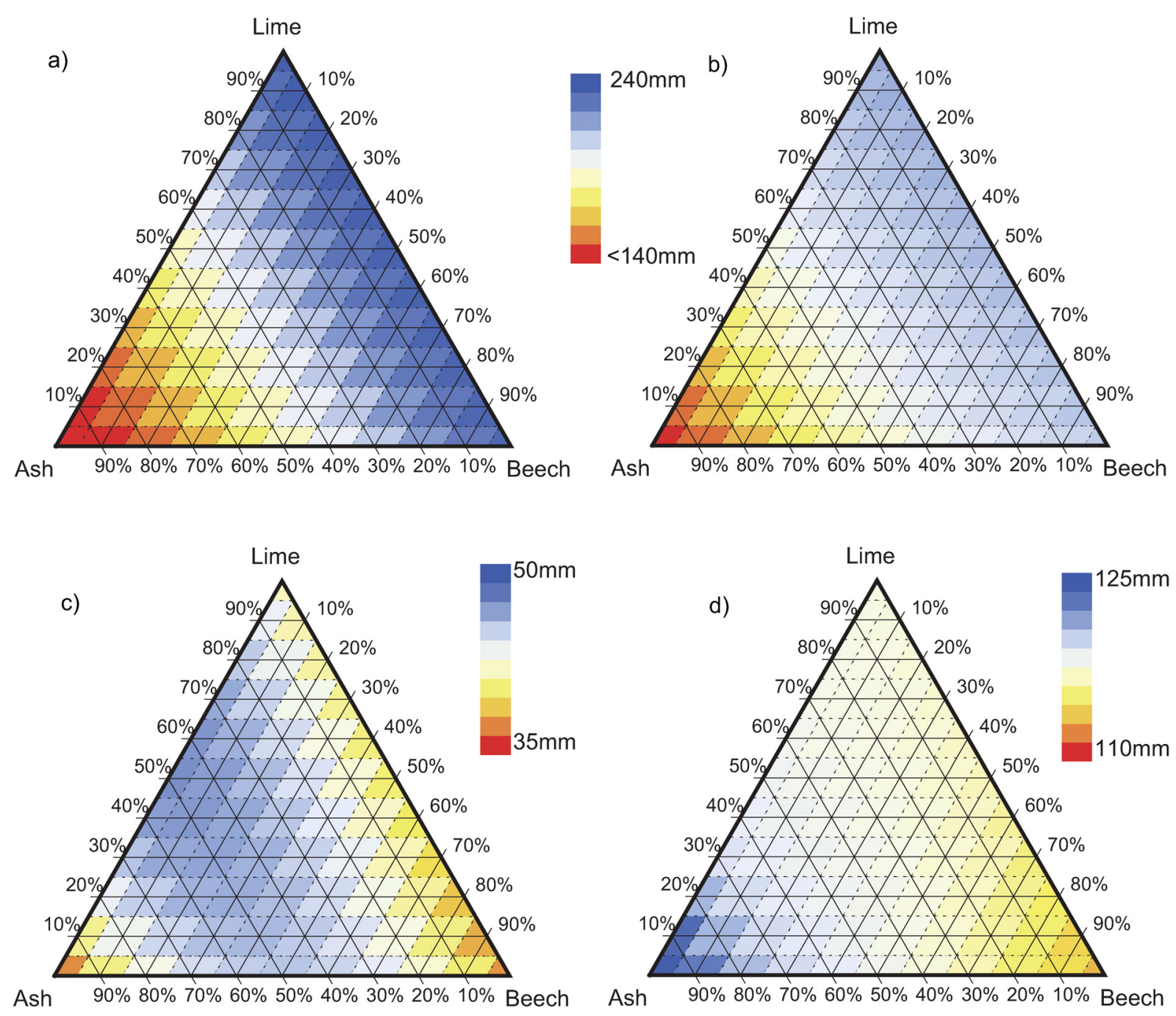

Figure 5.7 Transpiration ( $\mathrm{mm}$ ) of mixed stands of drought sensitive beech and drought tolerant lime and ash for the years 2005 (a), 2006 (b), for July 2006 (c) and for a hypothetical scenario with a 25\% reduction of the precipitation of 2006 (d).

The simulated reaction to dry soil water conditions is in accordance with observations during the rainless periods of the dry years 2003 and 2006. Thereby two contrary effects influence the tree water uptake at dry conditions. Low soil water contents lead to low leaf water potentials and therewith to stomatal closure decreasing evaporative water flow from the tree leaves to the atmosphere. In contrast dry and warm conditions lead to a higher evaporative demand and hence higher potential transpiration rates. The scenario calculations showed that depending on the tree species either one effect dominated or the effects levelled out. The ringporous ash was the most drought tolerant species and had the lowest soil water uptake throughout all years. The total water uptake of ash monocultures was higher in dry years compared with wet years due to a higher atmospheric evaporative demand (149 $\mathrm{mm}$ in 2003, 
$123 \mathrm{~mm}$ in 2005, $134 \mathrm{~mm}$ in 2006, $117 \mathrm{~mm}$ in 2007). Beech monocultures on the other side showed higher yearly water uptake in the wet years $(219 \mathrm{~mm}$ in $2003,233 \mathrm{~mm}$ in 2005 , $208 \mathrm{~mm}$ in 2006, $234 \mathrm{~mm}$ in 2007), because in the dry years beech reduced the xylem sap flux sensitively at low soil water contents. Lime monocultures showed the highest values of transpiration in all years, the yearly transpiration values $(249 \mathrm{~mm}$ in $2003,244 \mathrm{~mm}$ in 2005 , $239 \mathrm{~mm}$ in 2006, $234 \mathrm{~mm}$ in 2007) were similar at all years.

The tree species specific water uptake strategies were also reflected in the differences between the simulated yearly actual transpiration amounts of the assumed beech, lime, and ash monocultures of the years 2003, 2005, 2006, and 2007. The difference between beech and ash was lower in the dry years $(70 \mathrm{~mm}$ in $2003,74 \mathrm{~mm}$ in 2006$)$ than in the wet years $(110 \mathrm{~mm}$ in $2005,117 \mathrm{~mm}$ in 2007). The difference between beech and lime disappeared in the wet year 2007 and was low in the other years ( $8 \mathrm{~mm}$ in 2003, $6 \mathrm{~mm}$ in 2005, $6 \mathrm{~mm}$ in 2006).

The model scenario showed that the minimum of the volumetric soil water content $\theta_{V}$ at the end of a drought period is lower in stands with drought tolerant species (unpublished data) as result of the better capability of these species to extract water at low soil matric potentials. This indicates that the exhaustion of soil water by drought tolerant species can increase water stress and may damage the drought sensitive species in mixed stands of drought tolerant and drought sensitive species under very dry conditions.

\subsection{CONCLUSION}

By coupling models that describe physiological and hydrological processes we were able to simulate the water balance and water dynamics of the three forest stands. In accordance with precedent observational studies (Krämer and Hölscher, 2009; Gebauer, 2010) this modelling study showed that rainfall interception and transpiration did not generally correlate with species diversity. It was not possible to trace back the differences of the interception loss to single tree species. Also the impact of different water uptake functions of the different species on soil water flow and yearly transpiration rates could not be identified due to the strong overlay by differences in soil water infiltration and soil hydrological characteristics between the tree study plots.

An analysis of the daily values of transpiration and the volumetric soil water contents showed that the low soil water contents during periods with low rainfall can lead to water stress of the 
trees and that these periods occurred in the years 2005 and 2006. Scenario calculations of tree species composition based on the same hydraulic characteristics showed that the simulated water exhaustion can differ between stands of different mixtures of drought tolerant and sensitive species. The exhaustion of soil water by drought tolerant species could increase the water stress for drought sensitive species and may possibly decrease ecosystem stability at sites, where the plant available soil water is low during the vegetation period.

In future studies the model should be extended to also consider the damage of trees due to water stress. Moreover, the analysis of neighbouring effects, especially between drought tolerant and drought sensitive species can lead to a better understanding of the interaction of trees in mixed forests and may be particularly useful to predict future water dynamics under the expected climate change towards warmer and drier conditions.

\subsection{ACKNOWLEDGEMENT}

This study was conducted in the framework of the research project 'The role of biodiversity for biogeochemical cycles and biotic interactions in temperate deciduous forests' (DFG Research Training Group 1086) with funding from the German Research Foundation (DFG).

\subsection{REFERENCES}

Allen RG, Pereira LS, Raes D, Smith M. 1998. Crop evaporation: Guidelines for computing crop requirements. Irrigation and Drainage Paper No. 56, FAO, Rome, Italy.

Calder IR. 2007. Forests and water - Ensuring forest benefits outweigh water costs. Forest Ecology and Management 251: 110-120.

CarboEurope. 2009. Carbo Europe database. www.carboeurope.org, Last visited: 10/01/2009.

Christiansen JR, Elberling B, Jansson P-E. 2006. Modelling water balance and nitrate leaching in temperate Norway spruce and beech forests located on the same soil type with the CoupModel. Forest Ecology and Management 237: 545-556.

Christiansen JR, Vesterdal L, Callesen I, Elberling B, Schmidt IK, Gundersen P. Accepted. The role of six European tree species and land-use legacy for nitrogen and water budgets in forests. Global Change Biology. 
Dalsgaard L. 2007. Above and below ground gaps - the effects of a small canopy opening on throughfall, soil moisture and tree transpiration in Suserup Skov, Denmark, Ecological Bulletins 52: 81-102.

Deguchi A, Hattori S, Park H-T. 2006. The influence of seasonal changes in canopy structure on interception loss: Application of the revised Gash model. Journal of Hydrology 318: 80-102.

Droogers P. 2000. Estimating actual evapotranspiration using a detailed agro-hydological model. Journal of Hydrology 229: 50-58.

Dünisch O, Morais RR. 2002. Regulation of xylem sap flow in an evergreen, a semideciduous, and a deciduous Meliaceae species from the Amazon. Trees 16: 404-416.

DWD. 2009. Deutscher Wetterdienst. www.dwd.de Last visited: 10/01/2009.

Engel T, Priesack E. 1993. Expert-N, a building block system of nitrogen models as resource for advice, research, water management and policy. In: Eijsackers HJP, Hamers T (Eds.): Integrated Soil and Sediment Research: A Basis for proper Protection. Kluwer Academic Publishers, Dordrecht, The Netherlands, pp. 503-507.

FAO. 2005. Global Forest Resources Assessment. FAO Forestry Paper 147. FAO, Rome.

Feddes RA, Kowalik PJ, Zaradny H. 1978. Simulation of field water use and crop yield. Simulation Monographs. Wageningen: Pudoc.

Fischer B, Goldberg V, Bernhofer C. 2008. Effect of a coupled soil water-plant gas exchange on forest energy fluxes: Simulations with the coupled vegetation-boundary layer model HIRVAC. Ecological Modelling 214: 75-82.

Gale MR, Grigal DF. 1987. Vertical root distributions of northern tree species in relation to successional status. Canadian Journal of Forest Research 17: 829-834.

Gash JHC, Lloyd CR, Lachaud G. 1995. Estimating sparse forest rainfall interception with an analytical model. Journal of Hydrology 170: 79-86.

Gebauer T, Horna V, Leuschner C. 2008. Variability in radial sap flux density patterns and sapwood area among seven co-occurring temperate broad-leaved tree species. Tree Physiology 28: 1821-1830.

Gebauer T. 2010. Water turnover in species-rich and species-poor deciduous forests: xylem sap flow and canopy transpiration. Göttingen Centre for Biodiversity and Ecology. Biodiversity and Ecology Series B Vol. 4. University of Göttingen, Göttingen.

Granier A. 1985. Une nouvelle méthode pour la mesure du flux de sève brute dans le tronc des arbres., Annals of Forest Science 42: 193-200. 
Granier A. 1987. Evaluation of transpiration in a Douglas-fir stand by means of sap flow measurements. Tree Physiology 3: 309-320.

Granier A, Huc R, Barigah ST. 1996. Transpiration of natural rain forest and its dependence on climatic factors. Agricultural and Forest Meteorology 78: 19-29.

Granier A, Biron P, Lemoine L. 2000. Water balance, transpiration and canopy conductance in two beech stands. Agricultural and Forest Meteorology 100: 291-308.

Guckland A, Jacob M, Flessa H, Thomas FM, Leuschner C. 2009. Acidity, nutrient stocks and organic matter content in soils of a temperate deciduous forest with different abundance of European beech (Fagus sylvatica L.). Journal of Plant Nutrition and Soil Science 172: 500-511.

Herbst M, Roberts JM, Rosier PTW, Taylor ME, Gowing DJ. 2007. Edge effects and forest water use: A field study in a mixed deciduous woodland. Forest Ecology and Management 250: $176-186$.

Hoff C, Rambal S, Joffre R. 2002. Simulating carbon and water flows and growth in a Mediterranean evergreen Qercus ilex coppice using the FOREST-BGC model. Forest Ecology and Management 164: 121-136.

Hölscher D, Koch O, Korn S, Leuschner C. 2005. Sap flux of five co-occurring tree species in a temperate broad-leaved forest during seasonal soil drought. Trees 19: 628-637.

Hutson JL, Wagenet RJ. 1992. LEACHM: Leaching estimation and chemistry model., Research Series No. 92-93, Version 3. Department of Soil, Crop and Athmospheric Sciences, Ithaca, USA.

Iida S, Ohta T, Matsumoto K, Nakai T, Kuwada T, Kononov AV, Maximov TC, van der Molen MK, Dolman H, Tanaka H, Yabuki H. 2009. Evapotranspiration from understory vegetation in an eastern Siberian boreal larch forest. Agricultural and Forest Meteorology 149: 1129-1139.

INRA, (L'Institut National de Recherche Agronomique: French National Institute for Agricultural Research). 2009. www.avignon.inra.fr/can_eye/, Last visited: 10/01/2009.

Jacob M, Leuschner C, Thomas FM. 2010. Productivity of temperate broad-leaved forest stands differing in tree species diversity. Annals of Forest Science 67: 503.

Javaux M, Schröder T, Vanderborght J, Vereecken H. 2008. Use of a three-dimensional detailed modeling approach for predicting root water uptake. Vadose Zone Journal 7: 1079-1088. 
Kelliher FM, Köstner BMM, Hollinger DY, Byers JN, Hunt JE, McSeveny TM, Meserth R, Weir PL, Schulze E-D. 1992. Evaporation, xylem sap flow, and tree transpiration in a New Zealand broad-leaved forest. Agricultural and Forest Meteorology 62: 53-73.

Klaassen W, Bosveld F, de Water E. 1998. Water storage and evaporation as constituents of rainfall interception. Journal of Hydrology 212-213: 36-50.

Köcher P, Gebauer T, Horna V, Leuschner C. 2009. Leaf water status and stem xylem flux in relation to soil drought in five temperate broad-leaved tree species with contrasting water use strategies. Annals of Forest Science 66: 101-112.

Korn S. 2004. Experimentelle Untersuchung der Wasseraufnahme und der hydraulischen Eigenschaften des Wurzelsystems von sechs heimischen Baumarten. PhD Thesis, GeorgAugust-Universität Göttingen, Göttingen.

Krämer I, Hölscher D. 2009. Rainfall partitioning along a tree diversity gradient in a decidous old-growth forest in Central Germany. Ecohydrology 2: 102-114.

Krämer I, Hölscher D. In press. Soil water dynamics along a tree diversity gradient in a deciduous forest in Central Germany. Ecohydrology.

Lai C-T, Katul G. 2000. The dynamic role of root-water uptake in coupling potential to actual transpiration. Advances in Water Resources 23: 427-439.

Leuschner C, Jungkunst HF, Fleck S. 2009. Functional role of forest diversity: Pros and cons of synthetic stands and across-site comparisons in established forests. Basic and Applied Ecology 10: 1-9.

Lüttschwager D, Rust S, Wulf M, Forkert J, Hüttl RF. 1999. Tree canopy and herb layer transpiration in three Scots pine stands with different stand structures. Annals of Forest Science 56: 256-274.

Marin CT, Bouten IW, Dekker S. 2000. Forest floor water dynamics and root water uptake in four forest ecosystems in northwest Amazonia. Journal of Hydrology 237: 169-183.

Meinen C. 2008. Fine root dynamics in broad-leaved deciduous forest stands differing in tree species diversity. PhD Thesis Thesis, University of Göttingen.

Meinen C, Leuschner C, Ryan NT, Hertel D. 2009. No evidence of spatial root system segregation and elevated fine root biomass in multi-species temperate broad-leaved forests. Trees 23: 941-950.

Mitchell K. 2005. The community Noah land surface model (LSM). User's guide puplic release Version 2.7.1. (ftp://ftp.emc.ncep.noaa.gov/mmb/gcp/ldas/noahlsm/ver_2.7.1), Last visited: 10/01/2009. 
Mölder A, Bernhardt-Römermann M, Schmidt W. 2008. Herb-layer diversity in deciduous forests: Raised by tree richness or beaten by beech? Forest Ecology and Management 256: $272-281$

Monteith JL. 1965. Evaporation and the environment. Symposia of the Society for Experimental Biology 19: 205-234.

Monteith JL. 1981. Evaporation and surface temperature. Quarterly Journal of the Royal Meteorological Society 107: 1-27.

Moore KE, Fitzjarrald DR, Sakai RK, Goulden ML, Munger JW, Wofsy SC. 1996. Seasonal variation in radiative and turbulent exchange at a deciduous forest in central Massachusetts. Journal of Applied Meteorology and Climatology 35: 122-134.

Nordén U. 1991. Acid deposition and throughfall fluxes of elements as related to tree species in deciduous forests of South Sweden. Water Air and Soil Pollution 60: 209-230.

Ogée J, Brunet Y. 2002. A forest floor model for heat and moisture including a litter layer. Journal of Hydrology 255: 212-233.

Oishi AC, Oren R, Novick KA, Palmroth S, Katul GG. 2010. Interannual invariability of forest evapotranspiration and its consequence to water flow downstream. Ecosystems 13: $421-436$.

Pataki DE, Oren R. 2003. Species differences in stomatal control of water loss at the canopy scale in a mature bottomland deciduous forest. Advances in Water Resources 26: 12671278.

Pataki DE, Oren R, Smith WK. 2000. Sap flux of co-occuring species in a western subalpine forest during seasonal soil drought. Ecology 81: 2557-2566.

Peck AK. 2004. Hydrometeorologische und mikroklimatische Kennzeichen von Buchenwäldern. Berichte des Meteorologischen Institutes der Universität Freiburg Nr. 10. University of Freiburg, Freiburg.

Perrochet P. 1987. Water uptake by plant roots - A simulation model, I. conceptual model. Journal of Hydrology 95: 55-61.

Price AG, Carlyle-Moses DE. 2003. Measurement and modelling of growing-season canopy water fluxes in a mature mixed deciduous forest stand, southern Ontario, Canada. Agriculture and Forest Meteorology 119: 69-85.

Priesack E, Achatz S, Stenger R. 2001. Parameterisation of soil nitrogen transport models by use of laboratory and field data. In: Shaffer MJ, Ma L, Hansen S (Eds.): Modelling Carbon and Nitrogen Dynamics for soil Management. CRC Press, Boca Raton, USA, pp. 461-484. 
Schaap MG, Leij FJ, van Genuchten MT. 2001. ROSETTA: a computer program for estimating soil hydraulic parameters with hierarchical pedotransfer functions, Journal of Hydrology 251: 163-176.

Schipka F, Heimann J, Leuschner C. 2005. Regional variation in canopy transpiration of Central European beech forests. Oecologia 143: 260-270.

Schlichting E, Blume H-P, Stahr K. 1995. Bodenkundliches Praktikum, Pareys Studientexte, 81. Blackwell Wissenschafts-Verlag, Wien.

Schmidt I, Leuschner C, Mölder A, Schmidt W. 2009. Structure and composition of the seed bank in monospecific and tree species-rich temperate broad-leaved forests. Forest Ecology and Management 257: 695-702.

Schwärzel K, Häntzschel J, Grünwald T, Köstner B, Bernhofer C, Feger K-H. 2007. Fundamentals of the spatially distributed simulation of the water balance of forest sites in a low-range mountain area. Advances in Geosciences 11: 43-47.

Schwärzel K, Feger K-H, Häntzschel J, Menzer A, Spank U, Clausnitzer F, Köstner B, Bernhofer C. 2009. A novel approach in model-based mapping of soil water conditions at forest sites. Forest Ecology and Management 258: 2163-2174.

Sen OL, Shuttleworth WJ, Yang Z-L. 2000. Comparative Evaluation of BATS2, BATS, and SiB2 with Amazon Data. Journal of Hydrometeorology 1: 135-153.

Šimunek J, Huang K, van Genuchten MT. 1998. The HYDRUS code for simulation the onedimensional movement of water, heat, and multiple solutes in variably-saturated media. Version 6.0, Research Report No. 144, U.S. Salinity Laboratory, USDA, ARS, Riverside, CA, USA.

Stenger R, Priesack E, Engel T. 1999. Expert-N. A tool for simulating nitrogen and carbon dynamics in the soil-plant-athmosphere system. In: Tomer M, Robinson M, Gielen G (Eds.): NZ Land Creatment Collective Proceedings Technical Session 20: Modelling of Land Treatment Systems, New Plymouth, New Zealand, pp. 19-28.

van Dijk AIJM, Keenan RJ. 2007. Planted forests and water in perspective. Forest Ecology and Management 251: 1-9.

van Genuchten M.T. 1980. A closed-form equation for predicting the hydraulic conductivity of unsaturated soils. Soil Science Society of America Journal 44: 892-898.

Vincke C, Breda N, Granier A, Devillez F. 2005a. Evapotranspiration of a declining Quercus robur (L.) stand from 1999 to 2001. I. Trees and forest floor daily transpiration. Annals of Forest Science 62: 503-512. 
Vincke C, Granier A, Bréda N, Devillez F. 2005b. Evapotranspiration of a declining Quercus robur (L.) stand from 1999 to 2001. II. Daily actual evapotranspiration and soil water reserve. Annals of Forest Science 62: 615-623.

Wilson KB, Hanson PJ, Mulholland PJ, Baldocchi DD, Wullschleger SD. 2001. A comparison of methods for determining forest evapotranspiration and its components: sapflow, soil water budget, eddy covariance and catchment water balance. Agricultural and Forest Meteorology 106: 153-168.

Wullschleger SD, Hanson PJ, Todd DE. 2001. Transpiration from a multi-species deciduous forest as estimated by xylem sap flow techniques. Forest Ecology and Management 143: $205-213$.

Wullschleger SD, Hanson PJ. 2006. Sensitivity of canopy transpiration to altered precipitation in an upland oak forest: evidence from a long-term field manipulation study. Global Change Biology 12: 97-109. 


\section{CHAPTER \\ 6}

\section{Discussion}

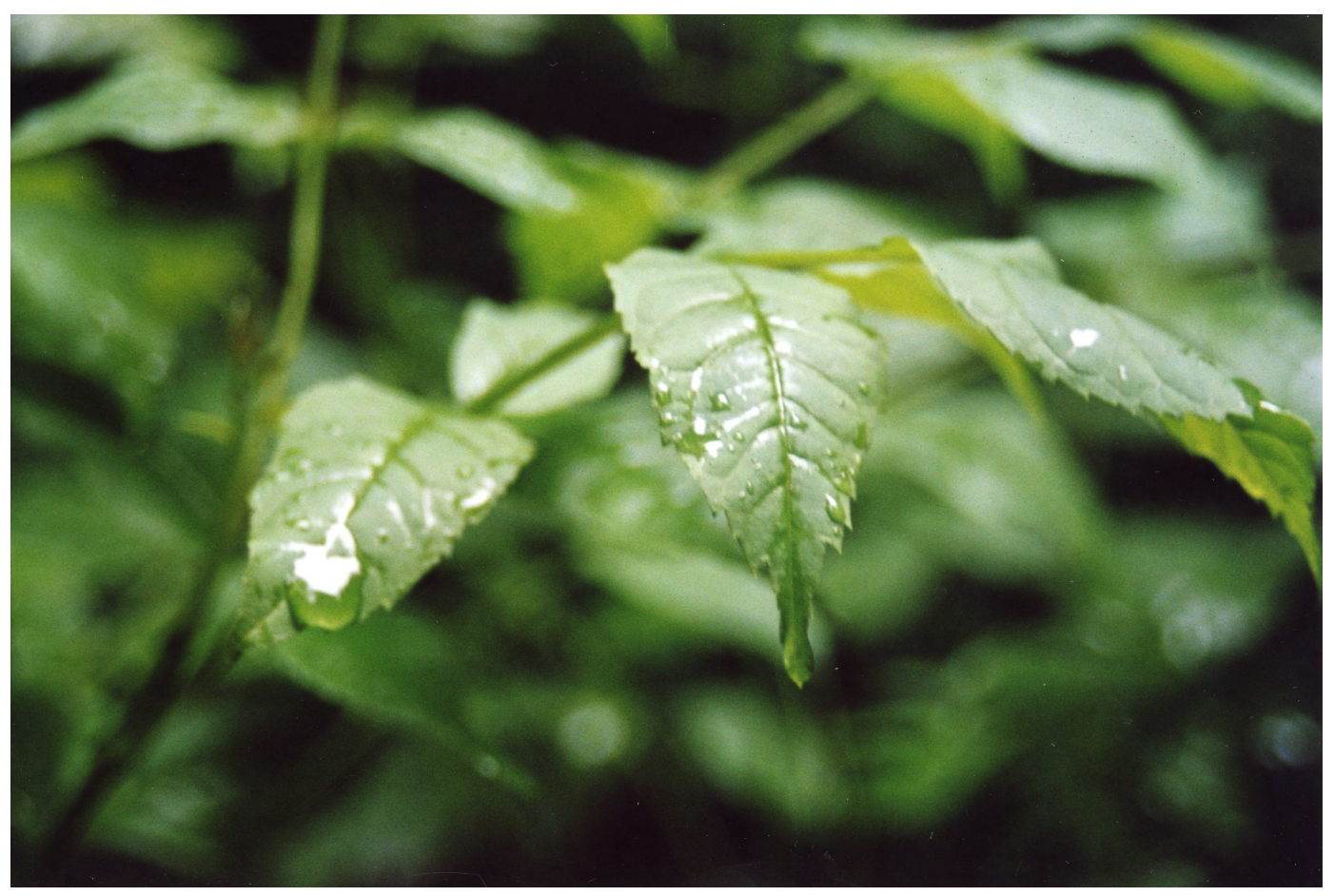


The overall discussion focuses on three main questions: Did biodiversity play a role for the observed effects along the tree species diversity gradient? Where are relationships among the studied subjects of this doctoral thesis? And where are relationships with the other studies of the umbrella project in the Hainich? For detailed discussions and literature comparisons of the single study subjects and results (rainfall partitioning, soil water dynamics, deposition and canopy exchange, water balance modelling), see discussions in the respective manuscripts (Chapter 2-5).

\subsection{OBSERVED EFFECTS ALONG THE TREE SPECIES DIVERSITY GRADIENT: DID BIODIVERSITY PLAY A ROLE?}

Investigated aspects of the forest hydrological cycle that correlated significantly with the tree species diversity gradient expressed as Shannon diversity index (H', Shannon and Weaver, 1949) were throughfall in some periods, stemflow during the whole study period (Chapter 2) and soil water extraction in a desiccation period in summer 2006 (Chapter 3). Also stand deposition of $\mathrm{K}^{+}, \mathrm{Ca}^{2+}, \mathrm{Mg}^{2+}, \mathrm{Cl}^{-}, \mathrm{Mn}^{2+}$, and $\mathrm{H}^{+}$correlated significantly with the Shannon index of the study plots (Chapter 4).

Following the definition by Loreau and Hector (2001), a biodiversity effect is either a complementarity or a selection effect. However, the complementarity effect is often supposed to be the 'real' biodiversity effect. Since we did not have the possibility to investigate all species in monocultures, it is not possible to distinguish clearly between complementarity and species selection effects. However, several indications for either of these effects on the above mentioned aspects exist and will be discussed.

Throughfall was significantly positively related to the tree species diversity gradient in summer 2005, autumn 2006, and summer 2007 (Chapter 2). In addition, it tended to increase along the investigated gradient in all studied periods. Supposedly, many stand and especially canopy characteristics together influenced throughfall differences among the study plots and were well represented by the Shannon diversity index. Since for example no single tree species explained throughfall differences more frequently than tree species diversity, a selection effect is unlikely. A complementarity effect would result for example from higher crown occupancy in mixed stands compared to monospecific beech stands, as it was shown by Frech et al. (2003) for a forest stand in the Hainich close to our study plots. Larger crown overlap could lead to a higher LAI (leaf area index) with increasing tree species diversity. 
However, LAI did not show a directed trend along the investigated tree species gradient (Jacob et al., 2010; M. Jacob personal communication) and throughfall increased rather than decreased with increasing tree species diversity. Although a diversity effect on throughfall is likely, it is not possible to identify the exact reason for the throughfall differences among the study plots. The relative importance of certain forest stand characteristics for throughfall seemed to be influenced by abiotic meteorological conditions.

The observed decrease in stemflow along the investigated tree species diversity gradient from monospecific beech to mixed tree species study plots was a clear species associated effect (Chapter 2). The higher stemflow amounts in the beech dominated plots can be related to a negative selection effect (Loreau and Hector, 2001), since many species with low stemflow amounts were included in the mixed species study plots and beech proportion decreased with increasing tree species diversity. Although hornbeam had high stemflow amounts as well, its proportion did not compensate for decreasing beech proportion on the study plots along the tree species diversity gradient.

At the beginning of a desiccation period in summer 2006 (June), soil water was much faster extracted with increasing tree species diversity of the study plots (Chapter 3 ). This resulted in low soil water reserves at the species rich plots one month later. Since water extraction of the study plots in June correlated better with tree species diversity than with any single tree species, a complementarity effect is more likely than a selection effect. Even though no indications of a spatial segregation of the fine roots of the coexisting species were found in 0 to $40 \mathrm{~cm}$ soil depth (Meinen et al., 2009c), roots exert different activity. Furthermore, water extraction of the herb layer probably played an important role in addition to the water uptake by the trees in the mixed study plots. This would support the complementarity effect, however, not only regarding diversity in the tree layer but also on an ecosystem level. A more rapid and more complete exploitation of soil water was also observed in highly diverse grasslands compared to species-poor grasslands and resulted in an earlier or more severe drought stress for the species in the diverse communities (Hooper and Vitousek, 1998; van Peer et al., 2004; Kreutziger, 2006; Verheyen et al., 2008).

The nutrient input by stand deposition (throughfall and stemflow) increased with increasing tree species diversity whereas the acid input decreased along this gradient and was highest in monospecific beech stands. This was related to two processes: interception deposition of ions and canopy exchange processes (leaching or uptake; Chapter 3). Deposition through gross precipitation was the same for all study plots. Interception deposition of all investigated ions 
(except for $\mathrm{SO}_{4}{ }^{2-}$ ) decreased with increasing tree species diversity (Chapter 4). This could be related to the higher beech dominated stands and their rougher canopies. Probably, the species specific leaf surface properties played a role as well. The outcome corresponds to the results of the throughfall investigation (Chapter 2), where also many stand characteristics probably acted together and were not possible to be separated clearly. Thereby, it is also difficult to divide a selection and a complementarity effect here. The canopy exchange rates of most of the ions $\left(\mathrm{K}^{+}, \mathrm{Ca}^{2+}, \mathrm{Mg}^{2+}, \mathrm{Fe}^{2+}, \mathrm{Cl}^{-}\right.$, and $\left.\mathrm{PO}_{4}{ }^{3-}\right)$ increased with increasing tree species diversity, which means that canopy leaching of these ions was highest at the most diverse study plots (Chapter 4). In contrast, the leaching of $\mathrm{Mn}^{2+}$ and $\mathrm{H}^{+}$was highest at the beech dominated plots. Canopy exchange is affected by the wettability, physiology, and ion status of foliage which differ between the tree species and thereby between forest stands. The differences in canopy exchange rates were therefore most likely a selection effect, although a complementarity effect can not be excluded. Besides, the differences in canopy exchange of some ions $\left(\mathrm{Mn}^{2+}, \mathrm{K}^{+}, \mathrm{Ca}^{2+}, \mathrm{Mg}^{2+}\right.$, and $\left.\mathrm{PO}_{4}{ }^{3-}\right)$ could arise from differences in soil properties, which are likely to have an impact on the foliar ion status (Chapter 4).

Both species effects as well as complementarity effects played a role in this study. We are aware that the investigated tree species diversity gradient corresponds to single species gradients at the same time. Although beech had the opposite gradient to the tree species diversity gradient, Shannon index of the study plots was in many cases a better explanatory variable than beech proportion of the study plots.

Various (environmental) factors can act as hidden sources of variability in biodiversity experiments (Healy et al., 2008). Such 'hidden treatments' (Huston, 1997) are difficult to avoid as well in experiments as in observational studies like the present one. This is most likely the reason why never one factor alone clearly explained the differences among the study plots in the present study. Besides the soil characteristics as for example clay content also some stand characteristics such as stand height, stand age, and canopy roughness provided hidden treatments. Furthermore, possible reasons for different stand characteristics can not only origin from differences in species composition but also from former management practices.

Observations along the studied tree diversity gradient are important for detecting patterns that can be investigated later in experiments. The subsequent second project phase (start in spring 2008) investigates clusters of tree species combinations including monospecific clusters of all tree species in the Hainich (Leuschner et al., 2009), trying to disentangle relations of certain 
species other than beech and neighbour effects. Furthermore, a tree species diversity experiment was established not far away from the Hainich area in 2003-2004 (SchererLorenzen et al., 2007). This so called BIOTREE experiment will become very interesting for comparison with the results of the studies in the Hainich because of the spatial vicinity and the similar tree species composition. All species were planted in monocultures and different combinations.

\subsection{RELATIONSHIPS AMONG THE STUDIED SUBJECTS}

It could be expected that patterns of rainfall partitioning, i.e. throughfall and stemflow, would be reflected in soil water dynamics. Interestingly, in summer 2006, soil water content of the study plots correlated with the tree species diversity gradient (Chapter 3), even though throughfall differences were not explained by this gradient (Chapter 2). Furthermore, within plot heterogeneity of throughfall and volumetric soil water content were not correlated with each other or with the tree species diversity gradient. This indicates that throughfall was not directly related to soil water dynamics and other factors were overlapping. A possible reason could be that the herb- and litter layer further influences throughfall on its way to the soil. Besides, a dominant biotic control of vegetation on soil water dynamics, which was indicated by pronounced seasonal dynamics, could play a role. Since soil water was not investigated close to stem bases, we have no information on the effect of stemflow on soil water dynamics.

Rainfall partitioning, i.e. throughfall and stemflow, did not show clear differences between seasons (Chapter 2), however, the stand deposition of most ions at least in throughfall did (Chapter 4). This indicates that stand deposition was strongly influenced by vegetation characteristics, i.e. seasonal changes in foliation of the trees and in the ion composition of leaves. The mixed study plots with highest throughfall percentages had the highest canopy leaching rates of most ions as well. Although on an area basis, ion deposition through stemflow was low compared to ion deposition through throughfall, some ions such as $\mathrm{K}^{+}$had higher concentrations in stemflow than in throughfall. Stemflow composition as a point input had a significant influence on the stem base and the surrounding soil (Levia and Frost, 2003).

Although soil water dynamics are not directly related to stand deposition, some loose relationships exist. It has to be noted though that before rainfall and its components reach the soil surface, they are not only intercepted by the canopy but in addition by the herb- and litter layer. Also in these layers directly above the soil, exchange processes take place (Jacob et al., 
2009) before the rainwater and its components enter the soil. When soil water becomes restricted in forest stands, also nutrient uptake could be more difficult. As in summer 2006, when soil water got more rapidly depleted in species rich stands, this could have led to restricted nutrient uptake too.

The model library Expert-N was able to simulate the measured interception and soil water dynamics well. This was already compared in detail in Chapter 5. Since the modelling study included the empirically derived data from the other studies (Chapter 2 and 3), it is not explicitly discussed here.

\subsection{RELATIONS TO OTHER STUDIES IN THE UMBRELLA PROJECT}

Hydrological studies are especially interesting when seen in an interdisciplinary context ('ecohydrology', see introduction). Since this study was carried out in a project group with many other studies in a wide range of disciplines, a discussion is possible, which not only compares the results with other studies on the same subject at other locations but moreover with findings from zoologists, botanists, soil scientists etc. from the same study plots in the Hainich National Park. The following discussion will focus on the comparison between results of this thesis and some other related studies carried out at the same time in the same study plots or directly adjacent to them.

\section{Aboveground}

One of the stand characteristics not correlated with the Shannon index of the study plots was the LAI (leaf area index) (Jacob et al., 2010). Notably, the LAI was rarely found to be a significantly explaining stand characteristic in our studies of rainfall partitioning (Chapter 2) and stand deposition (Chapter 4). LAI as a result from leaf collection in litter traps (Jacob et al., 2010) and PAI (plant area index, including all parts of the trees) as a result from analyses by hemispherical photographs (I. Krämer, unpublished data, for the method see Chapter 2) did not obtain comparable results (Figure 6.1). Hemispherical photography and analyses mostly underestimate LAI (Bréda, 2003; Jonckheere et al., 2004), although the indirect methods measure even the PAI, which should be higher than the LAI, because the PAI includes all parts of the tree. However, the two methods did not only differ in the absolute values of the LAI and PAI, but the differences increased along the investigated gradient. This systematic error could result from the possibility that certain leaves (e.g. ash and lime) in the mixed 
stands were partly decomposed already before containers were emptied (this was done every 2-3 weeks in autumn). However, we used the data obtained by Jacob et al. (2010 and M. Jacob, unpublished data) for our studies (Chapter 2 and 4), because a direct method is supposed to contain less uncertainty than an indirect method (Jonckheere et al., 2004).

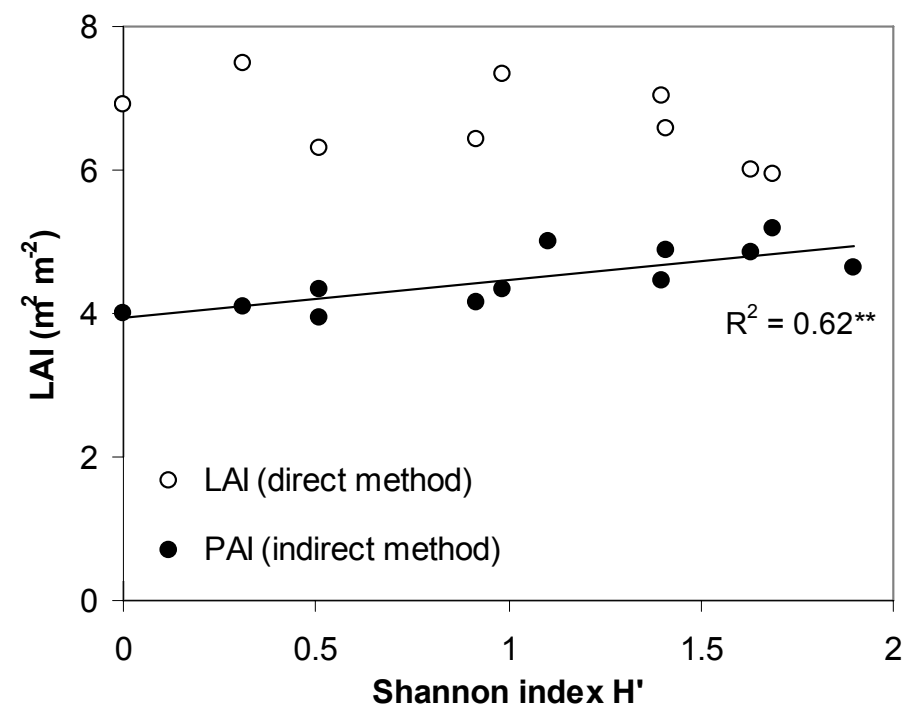

Figure 6.1 Comparison of LAI (leaf area index) obtained by a direct method (Jacob et al., 2010, and M. Jacob, personal communication) and PAI (plant area index) obtained by an indirect method (I. Krämer) along the tree species diversity gradient. Mean values of three years (2005-2007) $(* * \mathrm{p} \leq 0.01)$.

Light availability (irradiance transmitted through the closed canopy) did not correlate significantly with tree species diversity (Mölder et al., 2009). Furthermore, irradiance was not correlated with gap fraction of the study plots as investigated in the present study by analysis of hemispherical photographs (Chapter 2).

The temporal course of transpiration of the three investigated study plots (DL1a, DL2c, DL3a; Gebauer, 2010) was in congruence with the course of volumetric soil water content in vegetation periods (Chapter 3). Also differences in transpiration among the study plots were reflected in soil water content. However, some discrepancy exists between the amount of water extracted from soil and the amount of water used for transpiration calculated from soil water measurements (Chapter 3) and from transpiration measurements (Gebauer, 2010). One possible explanation is that the transpiration of the herb layer was not included in the transpiration measurements (see discussion in Chapter 3). Modelled transpiration rates were generally in the same order of magnitude as the measured transpiration data of three study 
plots. The overestimation of the modelled yearly transpiration rates of two beech dominated study plots in 2005 was probably related to after effects of the extreme drought in 2003 (Chapter 5). The model did not quantify possible damages of the water stress sensitive beech trees.

Herb layer biomass was positively correlated with tree species diversity (Mölder et al., 2008a, b). As mentioned before, the herb layer of the study plots probably had a marked influence on transpiration and interception of the study plots (Chapter 3). Also the stand deposition is affected by the herb layer, because exchange processes are likely to take place in this layer as well. The study plots did not differ much in the Ellenberg indicator value of the herb layer for soil water content (Mölder et al., 2008a). This indicator value revealed only that the monospecific beech plot DL1b was somewhat dryer and the monospecific beech plot DL1a wetter than the others. This could not directly be supported by the soil water measurements during the study period of more than two years. Following the environmental heterogeneity hypothesis (Huston, 1994), species diversity should increase with local heterogeneity of for example water availability. But herb layer diversity increased together with tree species diversity (Mölder et al., 2008a) and was therefore not correlated with soil water heterogeneity (Chapter 3 ) or throughfall heterogeneity (Chapter 2) on the study plots.

Litter production was the same in all study plots (Guckland et al., 2009b). However, litter layer thickness was negatively correlated with tree species diversity (Mölder et al., 2008a). In beech-dominated stands, litter from several years accumulated and formed a permanent layer of partly decomposed tree remains, whereas the thin organic layer of the mixed stands consisted primarily of leaf litter from the previous year (Guckland et al., 2009b). Litter layers have an effect on the interception process, which was in our study probably compensated by increasing herb layer biomass along the tree species diversity gradient. Cesarz et al. (2007) found that water content of the litter layer was as high as $66-82 \%$ in nine of the twelve study plots in the Hainich in February 2006. The water content of the litter layer correlated positively with tree diversity during winter and spring and decreased with decreasing litter depth (and therewith increasing tree species diversity) during the summer months (Cesarz at al., 2007; N. Weland personal communication). This supports the assumption that the litter layer on the beech study plots intercepts more water than on the mixed species study plots. Furthermore, exchange processes are likely to take place in the litter layer, affecting thereby also stand deposition of ions. Nutrient release from the litter layer was found to depend strongly on the tree species in our study plots (Jacob et al., 2009). 


\section{Belowground}

Fine roots $(<2 \mathrm{~mm}$ diameter $)$ and mycorrhizal hyphae are responsible for nutrient and water uptake of trees. Contrary to our expectations, we could not detect any direct relation between the fine root system in $0-40 \mathrm{~cm}$ soil depth and soil water dynamics in our study plots. Neither the total number of fine root tips in the profile nor the cumulative fine root surface area per ground area, stand fine root biomass or vertical root distribution patterns differed along the tree species diversity gradient (Meinen et al., 2009a). Moreover, there was no spatial segregation of the root systems of different species in the species rich stands and no additional soil volume was explored in the more diverse stands (Meinen et al., 2009c). Tree and herb fine root growth and volumetric soil water content (data: I. Krämer) were not correlated, testing both annual mean and mean of June-August 2006 (Meinen et al., 2009b). Although stand deposition of ions differed along the tree species diversity gradient, the fine root system did not.

Uptake rates of water and nutrients may depend next to root structural parameters on the amount of infection with mycorrhiza and the type of mycorrhizal association. Rhizomorphs of ectomycorrhiza represent functional extensions of the root system that can absorb and transport water and exploit soil water not available to the roots directly (Duddridge et al., 1980; Brownlee et al., 1983). This can be especially important under conditions in which the roots of the plant are in dry soil and the mycelium can absorb water in quantities sufficient to maintain leaf turgor and photosynthesis (Brownlee et al., 1983). The fine roots of the trees in the study plots were to more than $85 \%$ infected by mycorrhiza (Lang, 2008). Beech, lime, and hornbeam are mainly infected by ectomycorrhiza, hence, water uptake of especially these species may strongly be influenced by mycorrhiza. One species (Cenococcum geophilum), which occurs on all investigated tree species, is known to protect the plant from drought stress by storing water in the hyphmantel (Pigott, 1982; di Pietro, 2007). Although there is such a close relationship between mycorrhiza and soil water, regression analyses showed no clear correlation between mycorrhiza species and soil water content (data: I. Krämer) of the study plots (Lang, 2008).

Atmospheric $\mathrm{CH}_{4}$ uptake in soils is mainly controlled by soil moisture, which regulates methane flux into the soil through diffusion (Adamsen and King, 1993; Butterbach-Bahl and Papen, 2002; Borken et al., 2006). This was also shown for the study plots in the Hainich. The soils of three investigated study plots (DL1b, DL2a, DL3c) were a net-sink for atmospheric $\mathrm{CH}_{4}$ (Guckland et al., 2009a). The seasonal dynamics of atmospheric $\mathrm{CH}_{4}$ uptake were mainly 
driven by changes in water-filled pore space in the upper $5 \mathrm{~cm}$ of the mineral soil and related to amounts of gross precipitation during the vegetation periods. In the rather dry summer 2006, $\mathrm{CH}_{4}$ uptake was markedly higher than in the high-rainfall summer 2007. Differences of the $\mathrm{CH}_{4}$ uptake among study plots were primarily caused by the spatial variability of soil texture and in particular the clay content in the upper mineral soil layer ( 0 to $5 \mathrm{~cm}$ ) (Guckland et al., 2009a). Volumetric soil water content at $0-5 \mathrm{~cm}$ soil depth as calculated from the measurements by A. Guckland was very similar to volumetric soil water content data in $10 \mathrm{~cm}$ soil depth at the same measuring dates as investigated in the present study (Figure 6.2). This indicates that the calibration of the FDR probe was satisfactorily and also the use of water content data at $10 \mathrm{~cm}$ soil depth for $0-5 \mathrm{~cm}$ (in Chapter 3) was justified.

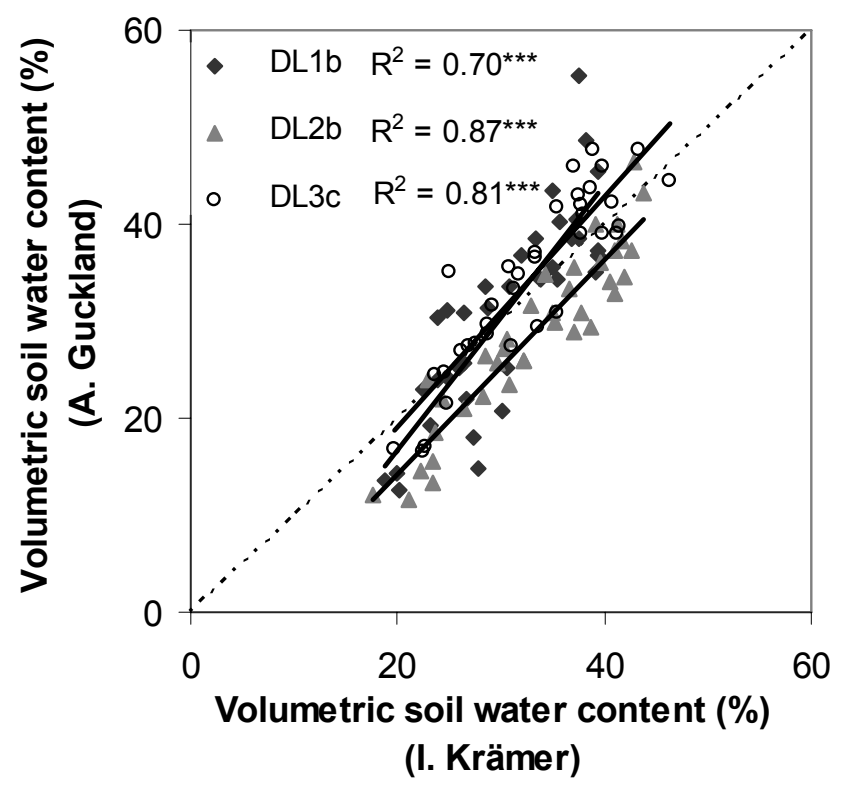

Figure 6.2 Comparison of volumetric soil water content at $0-5 \mathrm{~cm}$ soil depth calculated from direct measurements by A. Guckland and at $10 \mathrm{~cm}$ soil depth from FDR-measurements by I. Krämer; same three study plots (DL1b, DL2b, and DL3c) and same dates $(* * * p \leq 0.001)$.

Although earthworm activity and abundance was found to be influenced strongly by soil moisture (Edwards and Bohlen, 1996), this relationship was not found on our study plots (Cesarz et al., 2007). Besides, earthworms influence soil moisture by changing soil structure, and their channels are preferential ways for water flow (Tomlin et al., 1995). Especially Lumbricus terrestris is known for soil mixing and its vertical burrows, which could be one cause for the soil water heterogeneity on the study plots. This species occurred in all study 
plots (Cesarz et al., 2007), with a tendency of increasing density with increasing tree species diversity (N. Weland, personal communication).

The more acidic soils of the beech dominated study plots (Guckland et al., 2009b) probably led to higher leaf contents of $\mathrm{Mn}^{2+}$ and therefore higher leaching rates of this ion in the canopy (Chapter 4). Whereas the higher contents of $\mathrm{K}^{+}, \mathrm{Ca}^{2+}, \mathrm{Mg}^{2+}$, and $\mathrm{PO}_{4}{ }^{3-}$ in the soil on the mixed species plots (Guckland et al., 2009b; Talkner et al., 2009) may have led to the higher contents in leaves (Jacob et al., 2009) and higher leaching rates of these elements (Chapter 4).

\subsection{CONCLUSION}

Summarising, several connections between the investigated tree species diversity gradient and ecohydrological aspects could be observed. The results of this study add some knowledge to the hydrological cycle and ecohydrological aspects of temperate deciduous broadleaved forests and were closely connected to other investigated subjects in the umbrella research group in the Hainich National Park. The results further indicate that the conversion of monospecific beech forests to mixed stands of beech with different broadleaved tree species would tend to increase throughfall and input of nutrients and decrease input of soil acidifying ions and stemflow amounts. In addition, admixture of other broadleaved tree species to beech stands could increase the intensity of soil water extraction in desiccation periods. The Hainich area is already today characterised by low precipitation and could thus be sensitive to reductions in rainfall amounts or changing rainfall intensities during vegetation periods as predicted for the future (Bates et al., 2008).

\subsection{REFERENCES}

Adamsen APS, King GM. 1993. Methane consumption in temperate and subarctic forest soils: rates, vertical zonation, and responses to water and nitrogen. Applied and Environmental Microbiology 59: 485-490.

Borken W, Davidson EA, Savage K, Sundquist ET, Steudler P. 2006. Effect of summer throughfall exclusion, summer drought, and winter snow cover on methane fluxes in a temperate forest soil. Soil Biology and Biochemistry 38: 1388-1395. 
Bréda NJJ. 2003. Ground-based measurements of leaf area index: a review of methods, instruments and current controversies. Journal of Experimental Botany 54: 2403-2417.

Brownlee C, Duddridge JA, Malibari A, Read DJ. 1983. The structure and function of mycelial systems of ectomycorrhizal roots with species reference to their role in forming inter-plant connections and providing pathways for assimilate and water transport. Plant and Soil 71: 433-443.

Butterbach-Bahl K, Papen H. 2002. Four years continuous record of $\mathrm{CH}_{4}$-exchange between atmosphere and untreated and limed soil of a N-saturated spruce and beech forest ecosystem in Germany. Plant and Soil 240: 77-90.

Cesarz S, Fahrenholz N, Migge-Kleian S, Platner C, Schaefer M. 2007. Earthworm communities in relation to tree diversity in a deciduous forest. European Journal of Soil Biology 43: S61-S67.

di Pietro M, Churin J-L, Garbaye J. 2007. Differential ability of ectomycorrhizas to survive drying. Mycorrhiza 17: 547-550.

Duddridge JA, Malibari A, Read DJ. 1980. Structure and function of mycorrhizal rhizomorphs with species references to their role in water transport. Nature 287: 834-836.

Edwards CA, Bohlen PJ. 1996. Biology and ecology of earthworms. Chapman and Hall: London.

Frech A, Leuschner C, Hagemeier M, Hölscher D. 2003. Nachbarschaftsbezogene Analyse der Kronenraumbesetzung von Esche, Hainbuche und Winterlinde in einem artenreichen Laubmischwald (Nationalpark Hainich, Thüringen). (Neighbor-dependent canopy dimensions of ash, hornbeam, and lime in a species-rich mixed forest (Hainich Nationalpark, Thuringia)). Forstwissenschaftliches Centralblatt 122: 22-35.

Gebauer T. 2010. Water turnover in species-rich and species-poor deciduous forests: xylem sap flow and canopy transpiration. PhD thesis. University of Göttingen, Göttingen. Göttingen Centre for Biodiversity and Ecology. Biodiversity and Ecology Series B4.

Guckland A, Flessa H, Prenzel J. 2009a. Controls of temporal and spatial variability of methane uptake in soils of a temperate deciduous forest with different abundance of European beech (Fagus sylvatica L.). Journal of Plant Nutrition and Soil Science 172: 500-511.

Guckland A, Jacob M, Flessa H, Thomas FM, Leuschner C. 2009b. Acidity, nutrient stocks and organic matter content in soils of a temperate deciduous forest with different abundance of European beech (Fagus sylvatica L.). Journal of Plant Nutrition and Soil Science 172: 500-511. 
Healy C, Gotelli NJ, Potvin C. 2008. Partitioning the effects of biodiversity and environmental heterogeneity for productivity and mortality in a tropical tree plantation. Journal of Ecology 96: 903-913.

Hooper DU, Vitousek PM. 1998. Effects of plant composition and diversity on nutrient cycling. Ecological Monographs 68, 121-149.

Huston MA. 1994. Biological diversity. Cambridge University Press.

Huston MA. 1997. Hidden treatments in ecological experiments: re-evaluating the ecosystem function of biodiversity. Oecologia 110: 449-460.

Jacob M, Weland N, Platner C, Schaefer M, Leuschner C, Thomas FM. 2009. Nutrient release from decomposing leaf litter of temperate deciduous forest trees along a gradient of increasing tree species diversity. Soil Biology and Biochemistry 41: 2122-2130.

Jacob M, Leuschner C, Thomas FM. 2010. Productivity of temperate broad-leaved forest stands differing in tree species diversity. Annals of Forest Science 67: 503.

Jonckheere I, Fleck S, Nackaerts K, Muys B, Coppin P, Weiss M, Baret F. 2004. Review of methods for in situ leaf area index determination. Part I. Theories, sensors and hemispherical photography. Agricultural and Forest Meteorology 121: 19-35.

Kreutziger Y. 2006. Rückkopplungseffekte verschieden diverser Grünlandökosysteme auf die Komponenten des Bodenwasserhaushalts an einem Auestandort der Saale. Ergebnisse des Jenaer Biodiversitätsexperiments. $\mathrm{PhD}$ thesis. University of Jena.

Lang C. 2008. Diversität der Ektomykorrhizen in verschieden artenreichen Laubbaumbeständen im Nationalpark Hainich (Thüringen). PhD thesis, Georg-August-Universität Göttingen.

Leuschner C, Jungkunst HF, Fleck S. 2009. Functional role of forest diversity: Pros and cons of synthetic stands and across-site comparisons in established forests. Basic and Applied Ecology 10: 1-9.

Levia DF Jr, Frost EE. 2003. A review and evaluation of stemflow literature in the hydrologic and biogeochemical cycles of forested and agricultural ecosystems. Journal of Hydrology 274: 1-29.

Loreau M, Hector A. 2001. Partitioning selection and complementarity in biodiversity experiments. Nature 412: 72-76.

Meinen C, Hertel D, Leuschner C. 2009a. Biomass and morphology of fine roots in temperate broad-leaved forests differing in tree species diversity: is there evidence of below-ground overyielding? Oecologia 161: 99-111. 
Meinen C, Hertel D, Leuschner C. 2009b. Root growth and recovery in temperate broadleaved forest stands differing in tree species diversity. Ecosystems 12: 1103-1116.

Meinen C, Leuschner C, Ryan NT, Hertel D. 2009c. No evidence of spatial root system segregation and elevated fine root biomass in multi-species temperate broad-leaved forests. Trees 23: 941-950.

Mölder A, Bernhardt-Römermann M, Schmidt W. 2008a. Herb-layer diversity in deciduous forests: Raised by tree richness or beaten by beech? Forest Ecology and Management 256: $272-281$.

Mölder A, Bernhardt-Römermann M, Schmidt W. 2008b. Zur Beziehung zwischen Baumschichtvielfalt und Produktivität der Krautschicht in Laubwäldern. Naturschutz und Biologische Vielfalt 60: 139-144.

Mölder A, Bernhardt-Römermann M, Schmidt W. 2009. Vielfältige Baumschicht reichhaltige Verjüngung? Zur Naturverjüngung von artenreichen Laubwäldern im Nationalpark Hainich. Allgemeine Forst- und Jagdzeitung 180: 76-87.

Pigott CD. 1982. Survival of mycorrhiza formed by Cenococcum geophilum Fr. in dry soils. New Phytologist 92: 513-517.

Scherer-Lorenzen M, Schulze E-D, Don A, Schumacher J, Weller E. 2007. Exploring the functional significance of forest diversity: A new long-term experiment with temperate tree species (BIOTREE). Perspectives in Plant Ecology, Evolution and Systematics 9: 5370 .

Shannon CE, Weaver W. 1949. The mathematical theory of communication. University of Illinois Press: Urbana.

Talkner U, Jansen M, Beese FO. 2009. Soil phosphorus status and turnover in centralEuropean beech forest ecosystems with differing tree species diversity. European Journal of Soil Science 60: 338-346.

Tomlin AD, Shipitalo MJ, Edwards WM, Protz R. 1995. Earthworms and their influence on structure and infiltration. In Earthworm ecology and biogeography in North America. Hendrix PF (ed); CRC Press: Boca Raton; 159-184.

van Peer L, Nijs I, Reheul D, de Cauwer B. 2004. Species richness and susceptibility to heat and drought extremes in synthesized grassland ecosystems: compositional vs physiological effects. Functional Ecology 18: 769-778.

Verheyen K, Bulteel H, Palmborg C, Olivié B, Nijs I, Raes D, Muys B. 2008. Can complementarity in water use help to explain diversity-productivity relationships in experimental grassland plots? Oecologia 156: 351-361. 


\section{Summary}

Species diversity effects have been extensively investigated in grassland ecosystems, however, little is known about the influence of tree species diversity on the forest water cycle. In this dissertation several hydrological processes including soil water dynamics, rainfall partitioning and the related ion deposition with rainfall have been investigated along a tree species diversity gradient. In addition, the results were used to model the water cycle. The studies were conducted in twelve study plots in old-growth deciduous forest stands in the Hainich National Park, Germany. Monospecific plots were formed by Fagus sylvatica (beech) and mixed forest plots consisted of a variable admixture of up to eleven broad-leaved deciduous tree species such as Tilia spec., Fraxinus excelsior, Carpinus betulus, and Acer pseudoplatanus.

The first part of this thesis presents the partitioning of rainfall into throughfall, stemflow, and interception along the tree species diversity gradient. The results demonstrated that several stand characteristics influenced rainfall partitioning. The major variable explaining throughfall for different seasons was tree species diversity expressed as Shannon index. For example, in the high-rainfall summer of 2007, median throughfall per study plot was between $66 \%$ and $77 \%$ of gross precipitation and correlated positively with the Shannon index of the study plots. Stemflow contributed only $2 \%$ to $6 \%$ of gross precipitation and was negatively correlated with the Shannon index. Interception showed no correlation with this beech to mixed forest gradient. These relationships were similar in summer 2005 and autumn 2006, yet no (or only weak) correlations between throughfall and tree diversity were observed during the other study periods. Multiple linear regressions supported the assumption that combinations of several stand characteristics were important for differences in throughfall among the study plots, such as the Shannon index and the mean diameter at breast height. Influential stand characteristics varied between seasons and years due to different rainfall conditions. Differences in small-scale heterogeneity of throughfall within the study plots did not change consistently with any stand characteristic along the tree species diversity gradient.

The second part of this thesis focuses on soil water dynamics along the tree species diversity gradient. Overall, seasonal patterns of soil water dynamics were similar in all study plots. During a desiccation period in summer 2006, the top soil water content was strongly correlated with tree species diversity of the twelve study plots. At the beginning of this desiccation period, soil water was extracted at higher rates in the species rich plots than in the 
beech-dominated plots. However, later during the desiccation period when atmospheric evaporative demand was higher, only the beech-dominated stands were able to further increase soil water extraction. On plots of high tree species diversity, soil water reserves were already low and soil water extraction reduced. Possible explanations for high water extraction rates in mixed species plots at the beginning of the desiccation period include species specific characteristics such as high maximum water use rate of some species, enhanced exploitation of soil water resources in mixed stands (complementarity effect), and additional water use of the herb layer, which increased along the tree species diversity gradient. Differences in smallscale heterogeneity of volumetric soil water content within the study plots did not change consistently with any stand characteristic along the tree species diversity gradient.

The third part of this thesis presents ion deposition with rainfall and related processes, i.e. interception deposition and canopy exchange, along the tree species diversity gradient. Precipitation deposition and stand deposition (throughfall plus stemflow) of the ions $\mathrm{Na}^{+}, \mathrm{Cl}^{-}$, $\mathrm{K}^{+}, \mathrm{Ca}^{2+}, \mathrm{Mg}^{2+}, \mathrm{PO}_{4}{ }^{3-}, \mathrm{SO}_{4}{ }^{2-}, \mathrm{H}^{+}, \mathrm{Mn}^{2+}, \mathrm{Al}^{3+}, \mathrm{Fe}^{2+}, \mathrm{NH}_{4}{ }^{+}, \mathrm{NO}_{3}{ }^{-}$and $\mathrm{N}_{\text {org }}$ were measured in nine of the twelve study plots along the tree species diversity gradient. Interception deposition and canopy exchange rates were calculated with a canopy budget model. The interception deposition of all ions except for $\mathrm{SO}_{4}{ }^{2-}$ decreased with increasing tree species diversity, whereas the canopy leaching rates of $\mathrm{K}^{+}, \mathrm{Ca}^{2+}, \mathrm{Mg}^{2+}, \mathrm{Fe}^{2+}, \mathrm{Cl}^{-}$and $\mathrm{PO}_{4}{ }^{3-}$ increased with increasing tree species diversity. Stand deposition of $\mathrm{K}^{+}, \mathrm{Ca}^{2+}, \mathrm{Mg}^{2+}$ and $\mathrm{Cl}^{-}$increased and stand deposition of $\mathrm{Mn}^{2+}$ and $\mathrm{H}^{+}$decreased along the gradient. Possible reasons are differences in ion status of the leaves, tree physiology, and soil characteristics. In conclusion, the nutrient input to the soil was higher in mixed species plots than in monospecific beech plots, whereas the acid input was highest in monospecific beech plots.

In the forth part of this thesis, the observations of the first two studies were combined and used in the modelling framework Expert-N to simulate the water fluxes for a monospecific beech study plot and for two mixed study plots. Expert-N combines models for physiological and hydrological processes of the plant-soil system. Water fluxes were simulated by considering rainfall interception, evaporation, soil water flow, drainage, and root water uptake. Observations in the study plots provided reliable data for the parameterisation and the calibration of the model. Differences in rainfall interception and root water uptake among the study plots were realistically described. The applied stand-level model was thus able to simulate the water dynamics of the monospecific and mixed forest stands. The calculated water fluxes were sensitive to the species composition of the forest. 
The results of this dissertation demonstrate that rainfall partitioning, soil water extraction, and stand deposition of ions differed along the investigated tree species diversity gradient during certain periods. Both selection effects and complementarity effects played a role. These results provide information for the management of deciduous forests in Central Europe to meet public demands related to water resources as well as to ensure forest vitality under changing climatic conditions. 


\section{Zusammenfassung}

Der Einfluss von Biodiversität wurde bisher vor allem im Grünland erforscht und erst in den letzten Jahren sind auch Wälder in den Fokus der Biodiversitätsforschung gerückt. In der vorliegenden Dissertation wurde der Einfluss von Baumartendiversität auf Bestandteile des Wasserkreislaufes im Wald, wie Bodenwasserdynamik, Niederschlagsverteilung und die eng gekoppelte Deposition von Ionen mit dem Niederschlag, untersucht. Zusätzlich wurden die Daten und Ergebnisse genutzt, um den Wasserkreislauf zu modellieren. Für die Untersuchungen wurden zwölf Waldflächen entlang eines Baumartendiversitätsgradienten im Nationalpark Hainich, Deutschlands größtem zusammenhängenden Laubwaldgebiet, ausgewählt. Dieser Gradient reichte von reinen Buchenflächen (Fagus sylvatica) bis hin zu Flächen mit elf Baumarten wie Winter- und Sommerlinde (Tilia spec.), Esche (Fraxinus excelsior), Hainbuche (Carpinus betulus) und Bergahorn (Acer pseudoplatanus).

Der erste Teil der vorliegenden Dissertation behandelt die Niederschlagsaufteilung in Bestandesniederschlag, Stammablauf und Interzeption entlang des untersuchten Baumartendiversitätsgradienten. Die Baumartendiversität war die häufigste erklärende Variable für die Unterschiede im Bestandesniederschlag zwischen den untersuchten Flächen. Die Ergebnisse zeigen, dass mehrere Bestandeseigenschaften die Niederschlagsverteilung beeinflussten. So lag zum Beispiel im niederschlagsreichen Sommer 2007 der Bestandesniederschlag der Untersuchungsflächen zwischen 66 und 77\% des Gesamtniederschlags und korrelierte positiv mit dem Diversitätsgradienten. Der Stammablauf betrug nur 2\% bis 6\% des Gesamtniederschlags und nahm mit abnehmendem Buchenanteil auf den Flächen ab. Die Interzeption war nicht mit dem Diversitätsgradienten korreliert. Diese Beziehungen waren im Sommer 2005 und Herbst 2006 ähnlich, während in den anderen Untersuchungszeiträumen nur geringe oder keine Korrelationen mit dem Diversitätsgradienten vorhanden waren. Multiple lineare Regressionen unterstützten die Vermutung, dass mehrere Bestandeseigenschaften im Zusammenspiel wichtig waren, wie z.B. der Shannon-Diversitätsindex und der Brusthöhendurchmesser der Bäume. Beeinflussende Bestandeseigenschaften variierten zwischen den Jahreszeiten und Jahren aufgrund von unterschiedlichen Niederschlagsbedingungen. Unterschiede in der kleinräumigen Heterogenität des Bestandesniederschlages auf den einzelnen Flächen konnten mit keiner der gemessenen Bestandeseigenschaften erklärt werden. 
Der zweite Teil dieser Dissertation behandelt die Bodenwasserdynamik entlang des Baumartendiversitätsgradienten. Generelle jahreszeitliche Muster der Bodenwasserdynamik waren auf allen Untersuchungsflächen ähnlich. Während einer starken Austrocknungsperiode im Sommer 2006 war der Oberbodenwassergehalt eng mit der Baumartendiversität der zwölf Untersuchungsflächen korreliert. $\mathrm{Zu}$ Beginn dieser Austrocknungsperiode wurde das Bodenwasser auf den baumartenreichen Flächen schneller entzogen als auf den buchendominierten Flächen. Im weiteren Verlauf dieser Austrocknungsphase, als die mikrometeorologischen Bedingungen eine höhere Verdunstung bzw. Transpiration ermöglicht hätten, waren jedoch nur noch die buchendominierten Flächen in der Lage, ihre Wasseraufnahme weiter zu erhöhen. Auf den Flächen mit hoher Baumartendiversität waren die Bodenwasserreserven schon sehr gering und der Bodenwasserentzug ging zurück. Mögliche Erklärungen für die hohen Wasseraufnahmeraten in den Mischbeständen zu Beginn der Austrocknungsphase sind u.a. artspezifische Eigenschaften wie hohe maximale Wasseraufnahmeraten einiger Arten, erhöhte Ausnutzung von Bodenwasserressourcen in Mischbeständen (Komplementaritätseffekt) und zusätzliche Wasseraufnahme durch die Krautschicht, deren Biomasse entlang des Diversitätsgradienten anstieg. Unterschiede in der kleinräumigen Bodenwasserheterogenität auf den Flächen ließen sich nicht über den Baumartendiversitätsgradienten erklären.

Der dritte Teil dieser Dissertation behandelt die Deposition von Ionen mit dem Niederschlag und verwandte Prozesse (Interzeptionsdeposition und Ionenaustauschprozesse im Kronenraum) entlang des Baumartendiversitätsgradienten. Neben der Deposition im Freiland wurde die Deposition im Bestand (Bestandesniederschlag und Stammabfluss) der Ionen $\mathrm{Na}^{+}, \mathrm{Cl}^{-}, \mathrm{K}^{+}$, $\mathrm{Ca}^{2+}, \mathrm{Mg}^{2+}, \mathrm{PO}_{4}{ }^{3-}, \mathrm{SO}_{4}{ }^{2-}, \mathrm{H}^{+}, \mathrm{Mn}^{2+}, \mathrm{Al}^{3+}, \mathrm{Fe}^{2+}, \mathrm{NH}_{4}^{+}, \mathrm{NO}_{3}{ }^{-}$und $\mathrm{N}_{\text {org }}$ in neun Untersuchungsflächen gemessen. Interzeptionsdeposition und Kronenraumaustauschraten wurden mit einem Kronenbilanzmodell berechnet. Die Interzeptionsdeposition aller Ionen außer $\mathrm{SO}_{4}{ }^{2-}$ nahm mit zunehmender Baumartendiversität der Flächen ab, wohingegen die Kronenraumauswaschungsraten von $\mathrm{K}^{+}, \mathrm{Ca}^{2+}, \mathrm{Mg}^{2+}, \mathrm{Fe}^{2+}, \mathrm{Cl}^{-}$und $\mathrm{PO}_{4}{ }^{3-}$ mit ansteigender Baumartendiversität zunahmen. Insgesamt stieg mit zunehmender Baumartendiversität die Bestandesdeposition von $\mathrm{K}^{+}, \mathrm{Ca}^{2+}, \mathrm{Mg}^{2+}$ und $\mathrm{Cl}^{-}$an, die von $\mathrm{Mn}^{2+}$ und $\mathrm{H}^{+}$nahm hingegen ab. Dies ist sehr wahrscheinlich dem Ionenstatus der Blätter und der Baumphysiologie sowie den Bodeneigenschaften zuzuschreiben. Der Nährstoffeintrag in den Boden war also in den Mehrartflächen größer als in den buchendominierten Flächen, wohingegen der Säureeintrag in den buchendominierten Flächen am größten war. 
Im vierten Teil der Dissertation wurden die Ergebnisse und Daten aus den ersten beiden Untersuchungen genutzt, um die Wasserflüsse für eine Buchenfläche und zwei Mischwaldflächen mit Hilfe der Modellbibliothek Expert-N zu simulieren. Expert-N kombiniert Modelle für physiologische und hydrologische Prozesse des Pflanzen-Boden-Systems. Die berechneten Wasserflüsse umfassten Niederschlagsinterzeption, Evaporation, Bodenwasserfluss, Drainage und Wurzelwasseraufnahme. Messdaten von den Untersuchungsflächen und den beteiligten Baumarten boten eine gute Grundlage für die Parametrisierung und Kalibrierung des Modells. Die Unterschiede in Niederschlagsinterzeption und Wurzelwasseraufnahme zwischen den Untersuchungsflächen wurden realistisch beschrieben. Das verwendete Modell war daher in der Lage, die Wasserdynamik der Einart- und Mehrartflächen zu simulieren. Die berechneten Wasserflüsse variierten mit der Baumartenzusammensetzung.

Die Ergebnisse dieser Dissertation zeigen, dass Baumartendiversität den Wasserkreislauf beeinflussen kann. Die Niederschlagsverteilung, Bodenwasseraufnahme und Bestandesdeposition von Ionen unterschieden sich entlang des untersuchten Baumartendiversitätsgradienten in bestimmten Zeitabschnitten. Sowohl Selektionseffekte als auch Komplementaritätseffekte spielten vermutlich eine Rolle. Die Ergebnisse leisten einen Beitrag zu den Kenntnissen über mitteleuropäische Laubwälder und ihr Management auch in Bezug auf die Waldvitalität unter veränderten klimatischen Bedingungen und die Anforderungen der Gesellschaft, die Wasserressourcen zu sichern. 


\section{Acknowledgements}

First of all I would like to thank my supervisor Prof. Dr. Dirk Hölscher for providing and accompanying this interesting study project, for assistance, encouragement, and for creating a friendly and enjoyable work environment. The door was always open for discussions and motivation, thank you!

I also gratefully acknowledge Prof. Dr. Wolfgang Schmidt and Prof. Dr. Heiner Flessa for being part of my PhD-committee. I am especially thankful to Prof. Dr. Wolfgang Schmidt for his interest in this study and for reviewing the thesis.

I would like to thank Jörn Gollisch for handing over this project to me. He did a great job in the beginning of the project and I surely profited from his work. It is always difficult to take over work from others but Jörn was very helpful and made it possible.

To all my colleagues from the Department of Tropical Silviculture: thank you for the very nice working atmosphere. You all gave me very interesting insights into forests and silviculture of many different countries such as Vietnam, Philippines, and Pakistan. This added my study in the Hainich a very interesting international touch! In particular, I would like to thank Dr. Luitgard Schwendenmann und Diego Dierick for all the discussions and help, Mareike Roeder for nice breaks and lots of laughs, and Eva Siegelkow for helping whenever it was needed.

Thank you, all colleagues from the Graduiertenkolleg, for the friendly welcome, helpful discussions, good collaboration, data sharing, and for the enjoyable time we spent together in Göttingen and the Hainich National Park. Especially, I would like to thank Ulrike Talkner, Sebastian Bittner, and Meik Meißner for great cooperation. I furthermore thank Prof. Dr. Christoph Leuschner, Dr. Stefan Fleck, and Dr. Herrmann Jungkunst for organisation and coordination of the Research Training Group 'Graduiertenkolleg 1086: The role of biodiversity for biogeochemical cycles and biotic interactions in temperate deciduous forests'. Financial support was kindly granted by the DFG (German Research Foundation). I highly acknowledge the official management of the Hainich National Park for providing the permission to conduct research in Germany's largest remaining deciduous forest.

And not to forget: the nice lunch-break group at noon! Thanks for real breaks and wonderful companionship!

Of course I also want to thank my friends! Without you, life would be grey.

And last but not least I want to thank Daniel and my family for all their support and love. 
